Universidade de São Paulo

Escola de Comunicação e Artes

Programa de Pós-Graduação em Artes Cênicas

\title{
O ATOR DIALÉTICO
}

Ney Luiz Piacentini 


\title{
Universidade de São Paulo
}

Escola de Comunicação e Artes

Programa de Pós-Graduação em Artes Cênicas

\section{O ATOR DIALÉTICO}

\author{
Ney Luiz Piacentini
}

Tese apresentada à Escola de Comunicação e Artes da Universidade de São Paulo, como um dos requisitos para a obtenção do título de Doutor em Artes Cênicas.

Área de concentração: Pedagogia teatral.

Linha de pesquisa: A formação do artista teatral.

Orientador: Prof. Dr. Armando Sérgio da Silva.

São Paulo, 2018. 
Autorizo a reprodução e divulgação total ou parcial deste trabalho, por qualquer meio convencional ou eletrônico, para fins de estudo e pesquisa, desde que citada a fonte. 


\section{FOLHA DE APROVAÇÃO}

Nome: Ney Luiz Piacentini

Título: $\mathrm{O}$ ator dialético

Tese apresentada à Escola de Comunicação e Artes da Universidade de São Paulo, como um dos requisitos para a obtenção do título de Doutor em Artes Cênicas.

Área de concentração: Pedagogia teatral.

Linha de pesquisa: A formação do artista teatral.

Orientador: Prof. Dr. Armando Sérgio da Silva.

Aprovada em:

Presidente da banca: Armando Sérgio da Silva

\section{Banca Examinadora}

Prof.(a) Dr.(a): Instituição:

Assinatura:

Prof.(a) Dr.(a): Instituição:

Assinatura:

Prof.(a) Dr.(a): Instituição:

Assinatura:

Prof.(a) Dr.(a): Instituição:

Assinatura: 
Ao Nilson (in memoriam). E à Companhia do Latão. 
Agradecimentos

O meu muito obrigado ao meu orientador, o professor Aramando Sérgio da Silva, que me conduziu de maneira calma e segura durante este processo. E a Alexandre Kavanji, Alexandre Roit, Aline Meyer, Andréia Nhur, Beatriz Bittencourt, Ben-Hur de Souza, Carminha Fávero Gôngora, Cibele Forjaz, Christine Röhrig, Daniel Puglia, Daniela Schitini, Deborah Lobo, Ébano Machado Piacentini, Edgar Castro, Eduardo Tessari Coutinho, Emerson Rossini, Érika Rocha, Georgette Fadel, Heitor Goldflus, Helena Albergaria, Flávia Coelho, Iná Camargo Costa, Ipojucan Pereira, Izabel Lima, Jairo Mattos, João Maria Silva Júnior, João Pissarra, Jessé Oliveira, Julian Boal, Kelly di Bertolli, Lara Dau Vieira, Lúcia de Léllis, Lucia Romano, Lurdes Maria Piacentini, Mahani Acir Piacentini de Souza, Marcelo Berg, Marcelo Braga, Manoel de Andrade, Marcia Azevedo, Márcio Silveira, Maria Lívia Goes Nobre, Maria Silvia Betti, Maria Tendlau, Maria Thais Lima Santos, Marina Henrique, Martin Eikmeier, Michel Mauch, Mirian Zarate Villalba. Mônica Riani, Namir Piacentini, Natália Belasalma, Natasha Belfort Pereira, Neiva Piacentini de Andrade, Nelita Piacentini, Nilmar Piacentini, Olivia Tamie, Otávio Martins, Patrícia Belfort, Paula Lemos, Paulo Barcellos, Paulo Fávari, Rogério Bandeira, Rogério de Moura, Renata Kamla, Renata Vendramin, Ricardo Monastero, Tajin-Mahal Avelino Piacentini de Souza, Tamara Elizabeth, Victor Seixas e a todas e todos do CEPECA (Centro de Pesquisa e Experimentação Cênica do Ator - ECA/USP) e do LAPCA (Laboratório de Pesquisas e Criação do Ator - IA/Unesp). Agradeço especialmente a Márcio Marciano e a Sérgio de Carvalho, impulsionadores do projeto dialético da Companhia do Latão, e às equipes dos espetáculos do grupo, que serão mencionadas ao longo deste texto. 
Era um seminário de cultura, em 2008, e um militante do MST (Movimento dos Sem Terra) deu um depoimento e foi conversar comigo falando o seguinte: "Olha, eu sempre tive uma relação meio complicada com a escola, com o teatro, com a arte e essas coisas". Aí ele disse: "Não sei se você já ouviu falar de um grupo de teatro, a Companhia do Latão?". Eu disse: "Sim, já ouvi falar". Aí ele falou: "Então, eles começaram a fazer umas peças com a gente, mostrar pra gente e eu pensei: teatro e tal, coisa chata, daí eu resolvi ir lá. Daí eu comecei a ver e sempre tinha uma coisa que me incomodava no teatro que era a história deles falarem, eu sempre senti que eles favavam de cima pra baixo com a gente. Eles falavam: vou te ensinar alguma coisa que você está em um patamar inferior pra aprender isto. Aí de repente eu comecei a ver a peça, já de má vontade, mas quando a comecei a ver eles fazendo, aí eu falei: peraí, eu acho que isso aqui tá diferente. Daí tinha um cara lá, um ator, não, se eu fosse ator eu ia ser que nem esse sujeito aí. Sujeitinho invocado, ele fica brigando o tempo todo com a gente, enchendo e saco e tal. Mas peraí, tem uma coisa, eu percebi, ele briga não com a gente, atacando a gente. Mas ele briga junto com a gente, parece, e aí que eu percebi - peraí, isso é legal, entendeu. Daí eu falei, eu tô começando a prestar atenção nas ideias, no que tá sendo ensinado, no que tá sendo falado, mas eu tô pensando junto. Daí que eu achei legal, daí que eu vi que com o trabalho deles, com o trabalho dele, que ele tava fazendo naquelas cenas assim e depois a gente foi vendo outras, eu pensei, poxa, agora eu tô me divertindo de verdade. Mas, ao mesmo tempo que eu tô me divertindo, eu tô pensando. E aí eu achei legal. E aí que achei que isso que deve ser tipo escola, teatro, arte etc.”.

Daniel Puglia - Professor Doutor da FFLCH (Faculdade de Filosofia, Letras e Ciências Humanas da USP) 


\title{
RESUMO
}

PIACENTINI, Ney Luiz. O ator dialético. 2018. 262 p. Tese (Doutorado) - Escola de Comunicação e Artes / ECA-USP, São Paulo, 2018.

A presente pesquisa consiste no relato reflexivo de vinte anos de trabalhos como ator na Companhia do Latão, grupo teatral paulistano fundado em 1997. A análise se estende às visões dos demais intérpretes que integraram e integram esse coletivo cênico, cujo cerne é o aprendizado para uma atuação dialética. Tendo como fundamento as poéticas atorais de Constantin Stanislavski e Bertolt Brecht, minha escrita filtrou todas as produções espetaculares da Companhia, no sentido de apontar uma possível apropriação dos legados do dramaturgo alemão e do ator e diretor russo. E o que foi mais importante: de que modo propusemos nossos próprios meios pedagógicos, estéticos, políticos e técnicos nas salas de ensaios e apresentações públicas, para lidar tanto com textos estabelecidos por autores como Bertolt Brecht e Heiner Müller quanto os que foram criados pelo grupo. Orientei-me pelas minhas memórias, pelas publicações editadas pelo grupo, através dos depoimentos que colhi junto aos meus consortes, adicionando bibliografias sobre atuação, nacionais e estrangeiras. $\mathrm{O}$ resultado dessa interseção aponta para o levantamento de recursos e conceitos teatrais, indicando uma interpretação dialética no Brasil que, de forma alguma, encerra-se com este trabalho.

Palavras-chave: Atuação; cena; improvisação; dialética.

\begin{abstract}
PIACENTINI, Ney Luiz. The dialect actor. 2018. 262 p. Thesis (Doctorate) - Escola de Comunicação e Artes / ECA-USP, São Paulo, 2018.

The present research comprises a reflective account of twenty years of work as an actor in the Companhia do Latão, which is a theater group from São Paulo founded in 1997. The analysis extends to include the perspectives of other interpreters who have been part of, or continue to be part of, this theatre collective, whose core work is in learning for dialectical performance. Taking as a basis the original poetic writings of Constantin Stanislavski and Bertolt Brecht, my own writing has explored all the theatrical productions of the Company in order to point out a Brazilian appropriation to the legacies of the German playwright and the Russian actor and director. More importantly, the question was in how we proposed our own pedagogical, aesthetic, political, and technical methods in the rehearsal rooms and in public presentation, to deal with both the established texts by authors such as Bertolt Brecht and Heiner Müller, and those which were created by the group. I went through my memories, publications edited by the group, and the testimonials that I collected together with my colleagues, adding bibliographies on acting from Brazil and other countries. The result of this sythesis points to a collection of resources and theatrical concepts, indicating a dialectical interpretation in Brazil, a work which is in no way yet completed with this work.
\end{abstract}

Keywords: performance; scene; improvisation; dialect. 
INTRODUÇÃO .................................................................................................................................9

CAPÍTULO 1 - O APRENDIZADO DIALÉTICO .....................................................22

1.1 OS PRIMEIROS PASSOS DOS ATORES NA COMPANHIA DO LATÃO ................22

1.2 A COMÉDIA DO TRABALHO (2000) E AS OFICINAS INTERNAS .............................54

1.3 AS OBRAS DO PERÍODO INTERMEDIÁRIO …………………………………..... 74

CAPÍTULO 2 - A PRÁXIS DE UM ATOR DIALÉTICO................................................98

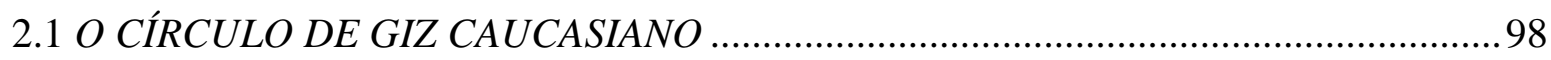

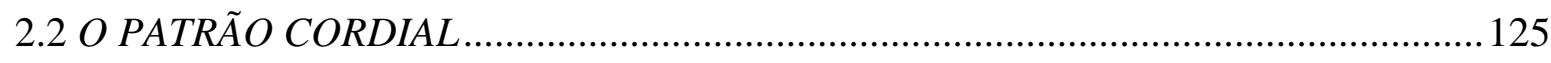

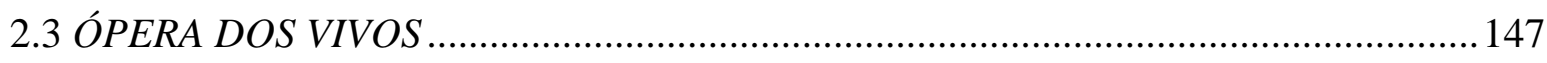

CAPÍTULO 3 - O PÃO E A PEDRA: UMA FÁBRICA COLETIVIZADA DE TEATRO (2016) ..........................................................................................................................................163

3.1 OS PASSOS INICIAIS SOBRE O ENREDO E A COLABORAÇÃO DOS ATORES 163

3.2 A PRODUÇÃO CÊNICA E DRAMATÚRGICA DA EQUIPE 175

3.3 AS DEVOLUTIVAS DO DRAMATURGO E DIRETOR AO TRABALHO DO GRUPO 190

3.4 RUMO À ESTREIA: A UNIÃO ENTRE A DRAMATURGIA, A ENCENAÇÃO E A ATUAÇÃO 200

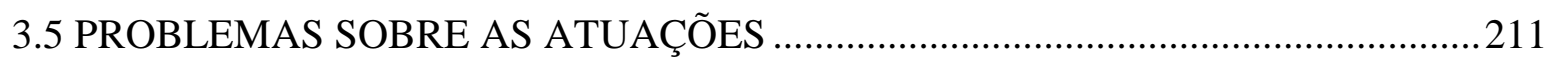

CONSIDERAÇÕES FINAIS............................................................................................219

REFERÊNCIAS BIBLIOGRÁFICAS ..........................................................................226 


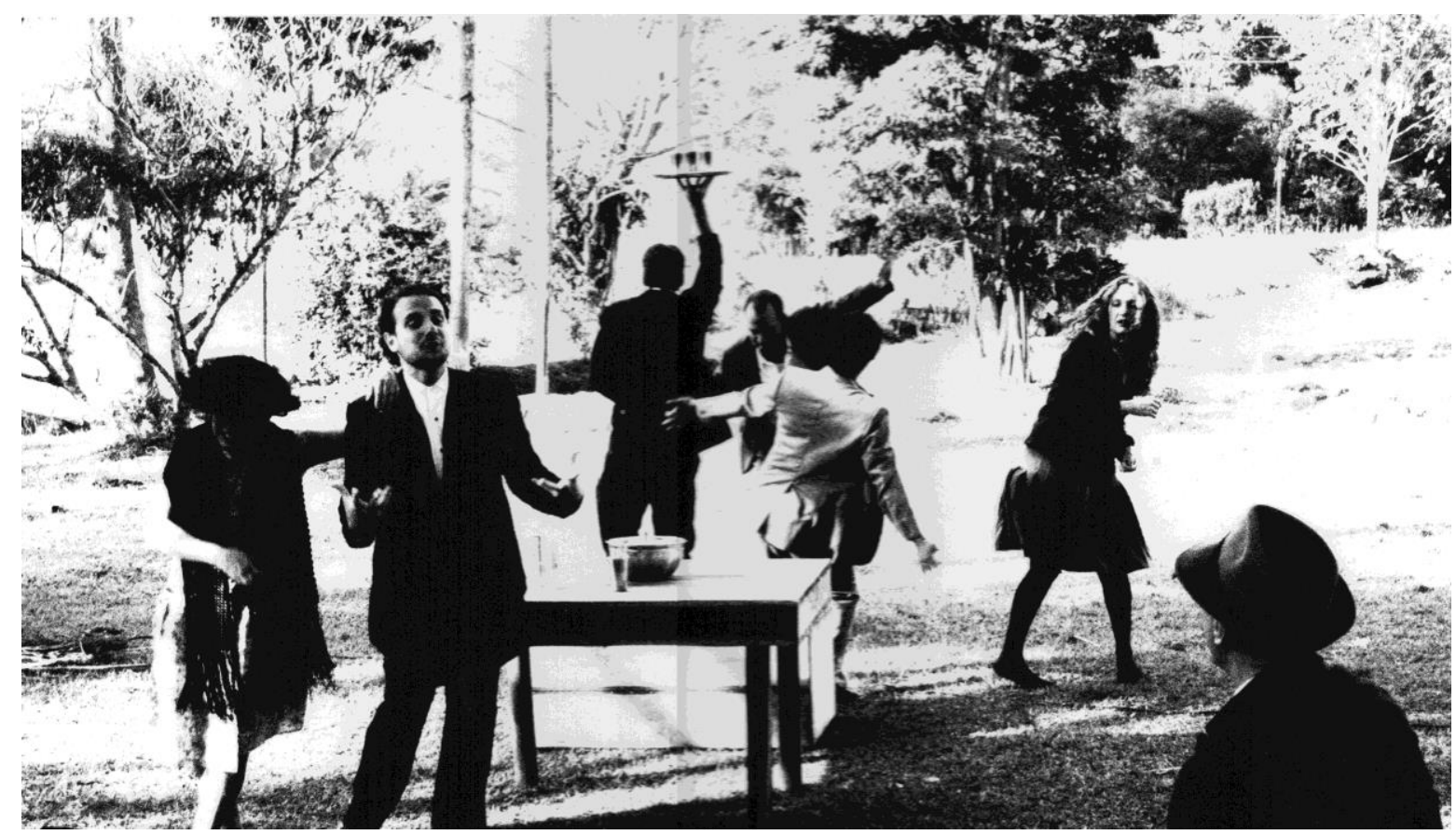

Adriana Mendonça, Martin Eikmeier, Rony Koren, Rogério Bandeira, Carlos Escher, Helena Albergaria e Ney Piacentini em uma apresentação de O patrão cordial, da Companhia do Latão, no Assentamento Carlos Lamarca - MST, Sarapuí/SP, em abril de 2013. Foto: Sérgio de Carvalho.

\section{INTRODUÇÃO}

Se neste introito contarei sobre o início do meu percurso que desaguou na Companhia do Latão (coletivo teatral sediado na cidade de São Paulo), no capítulo primeiro serão debatidas as primeiras peças do grupo (de Ensaio sobre o latão a Visões siamesas) e como seus atores absorveram o aprendizado épico-dialético proposto pelos nossos dramaturgos e diretores, Sérgio de Carvalho e Márcio Marciano. Na segunda parte, voltarei-me à análise de três projetos que foram exibidos em repertório: O círculo de giz caucasiano, Ópera dos vivos e $O$ patrão cordial. Neles, o centro das discussões serão as minhas operações atorais nesses espetáculos. No terceiro e último capítulo, observarei a peça $O$ pão e a pedra e como se deu a contribuição do elenco à constituição da dramaturgia e da encenação da obra.

Quanto ao contexto que me levou ao teatro, rememoro que a ditadura brasileira imposta em 1964 estava terminando e assim pegamos a transição para a reabertura política no país. Fomos, naturalmente, influenciados pelos que vieram antes de nós, desde os mais engajados até um setor da produção artística que não foi tão comprometido com a precária situação social do país. "Deixa eu cantar pro meu corpo ficar odara"1, cantava Caetano

\footnotetext{
1 “Odara”, de Caetano Veloso, canção do álbum Bicho, de 1977.
} 
Veloso. Ecos da contracultura chegavam aos nossos ouvidos, paralelos às expectativas familiares de que viéssemos a ser profissionais bem-sucedidos e, para tanto, teríamos que aderir ao fluxo capitalista vigente, sem contestações. Como tantos outros, frustrei a expectativa dos meus pais, tomando outro rumo.

Em 1979 eu estava deixando o curso de Engenharia Civil para fazer Psicologia na Universidade Federal de Santa Catarina. No teatro da UFSC, assisti a uma montagem de Um grito parado no ar, de Gianfrancesco Guarnieri, com o Grupo Armação de Florianópolis, e aquilo me atraiu. Dias depois, voltei aonde tinha visto a peça e me deparei com uma plaquinha que dizia: "Curso de Teatro". Na realidade, até hoje não sei por que entrei no Teatro da Igrejinha e ingressei no Grupo Pesquisa Teatro Novo, dirigido por Carmen Fossari: não havia frequentado espetáculos teatrais na infância ou adolescência, ninguém na minha família era da área e sequer eu conhecia pessoas do meio teatral. Todavia, foi quando encontrei Márlio da Silva e criamos um ajuntamento que veio a se chamar Grupo A de Teatro.

À época, em Lajes, no interior de Santa Catarina, havia o Grupo Gralha Azul dirigido pelo casal argentino Olga Romero e Hector Grillo. Nini Beltrame, por exemplo, nome importante no teatro catarinense, fazia parte desse conjunto. Elisa Oliveira, Duda Goetze, Márlio da Silva e eu fizemos uma oficina com eles e fomos ao Festival Nacional de Teatro de Bonecos em Lajes de 1980. Como consequência, nossa incipiente formação usava a estética do Gralha Azul, que unia o teatro de bonecos a intervenções com atores, teatralizando ideias que principalmente Márlio da Silva concebia e assim nos lançávamos à prática sem direção, sem cenógrafo ou figurinista e sem iluminador, pois atuávamos ao ar livre. O advento do nosso quarteto se deu com Ataíde, ai de ti, em meio à Paixão de Cristo, encenada anualmente pelo diretor Rio Apa entre as dunas da Lagoa da Conceição, na ilha de Santa Catarina. Fizemos uma inserção de meia hora, se tanto, como uma trupe de teatro que se apresentava ao povo que acompanhava os passos da Paixão. O nosso enredo, sem nenhuma relação com a história de Cristo, dizia sobre um adolescente que, pressionado pelos pais a prestar o serviço militar e a fazer o vestibular, fugia para uma praia local, o Pântano do Sul, unindo-se a um ser que chamamos de Gaivuru - meio gaivota, meio urubu, visto que naquela costa esses pássaros conviviam.

Em seguida, o Grupo del Silencio, dos mímicos argentinos Alberto Quesada e Daniel Berbedés, ancorara na capital catarinense e não só tivemos aulas com eles, como também essa dupla nos auxiliou no desenvolvimento de Ataíde, ai de ti, primeira peça do Grupo A. O que eles nos forneceram foram orientações stanislavskianas básicas, pedindo para que escrevêssemos em terceira pessoa as vidas dos personagens. Depois de lermos em ensaios os 
textos que cada um de nós havia redigido, a dupla platina nos solicitou novos relatos, mas desta feita em primeira pessoa. Esse simples dispositivo nos foi importante, pois, além de não termos feito uma escola de artes cênicas, sequer prosseguimos no curso livre de teatro da Universidade. Por meio do que eles nos transmitiram, aumentamos a vida dos papéis da peça e incorporamos no trabalho episódios vindos das narrativas por nós biografadas a pedido de Alberto e Daniel. Com calças de malha justa, maquiagem branca no rosto e algumas máscaras de papel machê feitas por nós mesmos, íamos com o nosso jovem teatro aos gramados da Universidade e em algumas comunidades da ilha.

Não me esqueço da primeira vez que fomos convidados a fazer uma apresentação, já que nesse começo nós nos oferecíamos. Alunos da Escola Técnica Federal de Florianópolis nos chamaram e, depois de nos trocarmos nos banheiros do colégio, mostramos a peça em um pátio. E como estávamos sendo bem recebidos também em outros espaços, encorajamo-nos a ponto de abandonarmos os estudos de graduação da Universidade. Não que isso tenha sido tranquilo. Anos depois, eu ainda sonhava que ia às aulas e dava satisfações ao meu pai sobre meus estudos formais. Porém, com 20 anos de idade deixei o curso de Engenharia (profissão dos meus dois irmãos mais velhos) e mais, ao largar também a Psicologia dois anos depois para fazer teatro, estava abrindo mão de ter um diploma de ensino superior, algo caro à classe média que se esforçava para colocar os filhos em uma faculdade. E nisso um contrassenso: a mesma universidade que me deu uma formação humanista com suas aulas de filosofia, palestras com intelectuais, mobilizações políticas e iniciação cultural, forneceu-me a consciência de que eu deveria deixá-la para fazer arte. No entanto, cada vez que a atividade teatral refreava, eu sofria que tinha que voltar a estudar e ter uma profissão convencional. Porém, bastava que algum pequeno intuito artístico vingasse para que o medo de não ter uma formação acadêmica temporariamente se dissipasse.

Com o Grupo A, em criações coletivas, eu faria mais três espetáculos: Adivinhe o nome da peça (1980), O universotário (1981) e Vira e mexe (1982) ${ }^{2}$. O primeiro contava a respeito de uma menina que, presa em um quintal, imaginava histórias para se divertir, representadas por bonecos. Pensado para o público infantil, para a nossa surpresa esse trabalho alcançou outras faixas etárias. O segundo era uma sátira do ambiente universitário,

\footnotetext{
${ }^{2}$ Em Ataíde, ai de ti, atuavam: Elisa Oliveira, Duda Goetze, Márlio da Silva e Ney Piacentini. Em Adivinhe o nome da peça, Elisa Oliveira, Márlio da Silva e Ney Piacentini. Em O universotário, Elisa Oliveira, Iran Melo, Márlio da Silva e Ney Piacentini. Em Vira e mexe, Elisa Oliveira, Fátima Lima, Márlio da Silva e Ney Piacentini, com música de Kaw Regis e Murilo Valente, sendo que, na versão paulistana, estavam: Ângela Dip (depois substituída por Vera Zimmermann), Fátima Lima, Ney Piacentini e Raul Barreto, com música de Du Moreira e João Branco.
} 
inclusive sobre um certo dogmatismo do movimento estudantil. O terceiro, também para crianças, tinha como mote a criatividade a partir de objetos cotidianos.

Com bolsas-arte do então Ministério da Educação e Cultura (MEC), alugamos uma casa para realizar o próximo projeto do grupo: Vivo numa ilha. Tínhamos a pretensão de contar a história da colonização de Florianópolis (chamada antes de Desterro) em dois planos: um mais fiel à vinda dos açorianos e outro fantástico, que narraria a formação das lagoas da Conceição e do Peri, entre outros episódios imaginados por Márlio da Silva. Ensaiávamos pela manhã no Teatro da Igrejinha e, à tarde, produzíamos os bonecos. Foi quando a cidade recebeu uma oficina e apresentações do Grupo Asdrúbal Trouxe o Trombone, do Rio de Janeiro. Fizemos as aulas com eles, que foram divertidas, vivas e intensas e mostramos uma parte do nosso Vivo numa ilha, contando depois a eles e aos demais oficinandos o restante do nosso futuro espetáculo. Se não me engano, foi Regina Casé que comentou: "Mas esse roteiro dá umas três peças”. Em seguida à passagem deles por lá, o Diretório Central dos Estudantes (DCE-UFSC), como já havia feito com outras de nossas peças, convidou-nos para nos apresentarmos na Semana dos Calouros. Deixamos de lado Vivo numa ilha e, em semanas, influenciados pela trupe carioca, fizemos $O$ universotário, que acabou circulando por dois anos, chegando a outras cidades do estado de Santa Catarina e ao Rio Grande do Sul. Amir Haddad, que nos viu naquele tempo, comentou que aquilo não era apenas a respeito do ambiente universitário sulista, mas sobre a juventude brasileira. Posteriormente, não tomei parte da retomada de Vivo numa ilha, em 1985, pois já estava em São Paulo.

Como sempre aconteceu, chegavam aqueles dias em que as perspectivas artísticas minguavam e tínhamos que recorrer a atividades paralelas para sobreviver. Assim, com Fátima Lima, fui dar aulas na estatal de energia Eletrosul e ainda estava como oficineiro em um projeto nas praias do sul da ilha. Os filhos dos funcionários da empresa eram crianças com cerca de 10 anos de idade e o espaço que tínhamos era um quiosque para festas. Ao invés de retirarmos as mesas e cadeiras de lá, passamos a utilizá-las como materiais segundo um dos exercícios que havíamos colhido junto ao Asdrúbal Trouxe o Trombone: o de um objeto ser transformado em vários outros, de acordo com o engenho de cada aluno. Desse modo, uma cadeira podia ser uma janela, um bicho, um abrigo etc. $\mathrm{O}$ mesmo com uma ou mais mesas. Foi tal o princípio que norteou o curso que demos às crianças urbanizadas e que depois serviu de base para Vira e mexe ${ }^{3}$, a terceira e última peça que fiz com o Grupo A.

\footnotetext{
${ }^{3}$ Prêmio Bastidores (1982/83) de Teatro como Melhor Espetáculo Infantil e Melhor Ator (Ney Piacentini). Em São Paulo (1987/88), Raul Barreto foi indicado ao Prêmio Mambembe como Melhor Ator Infantojuvenil.
} 
Três cadeiras e uma mesa, vinte cubos coloridos de papelão e uma arara com roupas catadas davam muitas possibilidades alinhavadas pela história de Albertinho, um adulto atrapalhado que escolhera um lugar abandonado para morar (o próprio teatro), e três crianças das redondezas que tinham aquele lugar como esconderijo. Além de ganhar prêmios em Santa Catarina, a peça foi refeita em São Paulo em 1987, com boa aceitação.

Enquanto Ataíde, ai de ti e Adivinhe o nome da história mesclavam bonecos com humanos, em $O$ universotário e Vira e mexe foram realizados apenas com atores e essa última não em espaços abertos, mas em palco convencional. Sobre a interpretação no Grupo A, ela era intuitiva, sem maiores referências, além do que víamos das peças que eram feitas em Santa Catarina, as locais e as que vinham de fora. De Constantin Stanislavski sabíamos o mínimo e sobre Jerzy Grotowski, Augusto Boal ou Antunes Filho, ouvíamos falar sem que houvesse em nós um grande interesse em conhecê-los melhor ou exercitá-los. Íamos em frente porque ninguém nos dizia para parar. É preciso levar em conta que em Santa Catarina, naquele tempo, o meio teatral era tímido e qualquer iniciativa era bem-vinda.

Em 1984, aos 24 anos de idade, fui convidado pela autora de teatro, roteirista e jornalista Roseli Galleti para entrar na RBS TV (filial da Rede Globo no Rio Grande do Sul e em Santa Catarina), para trabalhar no Jornal do Almoço, principal produção local. Eu faria, em dupla com Gilberto Colzani, um boneco irônico - comentarista do fato do dia - e, ainda, um segundo quadro de humor como ator. Fiquei em dúvida se deveria aceitar o emprego, pois o purismo de então fazia com que desconfiássemos da TV. Curiosamente, foi com esses salários que pela primeira vez na vida comprei um aparelho de televisão. O personagemboneco, Doutor Barroso ${ }^{4}$, virou a maior audiência do jornal e o quadro de humor, apresentado aos sábados, também repercutiu positivamente. Este durava de três a quatro minutos e nele fizemos o surfista de São Benedito (sátira ao surfista de Jesus, então muito conhecido em SC), o turista enganado, o malandro do centro da cidade, entre outros tipos, sem o uso de palavras e na edição acelerávamos as imagens para dar um efeito cômico. Era ingênuo, mas com sua graça. Ainda em Florianópolis, empreendemos, por dois verões seguidos (1983 e 1984), a Lonazul da Lagoa, um espaço para as artes em janeiro e fevereiro, embaixo de uma lona que pegamos emprestada ${ }^{5}$ da Secretaria de Agricultura, a qual cravamos nas belas areias à beira da Lagoa da Conceição. Música, teatro, dança e vídeo para fazer da principal temporada da cidade algo mais do que praias e surfe. Do Grupo A, fui também seu produtor e frequentava

\footnotetext{
${ }^{4}$ Os textos do quadro eram escritos inicialmente por Roseli Galleti e depois eu assumi a redação. Os braços do boneco eram feitos por Gilberto Colzani e a sua voz e cabeça ficavam por minha conta.

${ }^{5}$ Os condutores dessa iniciativa foram, principalmente, Ney Piacentini e Fátima Lima.
} 
as reuniões sobre os problemas da pequena comunidade teatral local, assim como corria as secretarias em busca de apoio para projetos. Os sete anos que vivi em Santa Catarina produziram a maior mudança da minha vida: foi lá que, ao invés de engenheiro ou psicólogo, me tornei, com seus bônus e ônus, um ator.

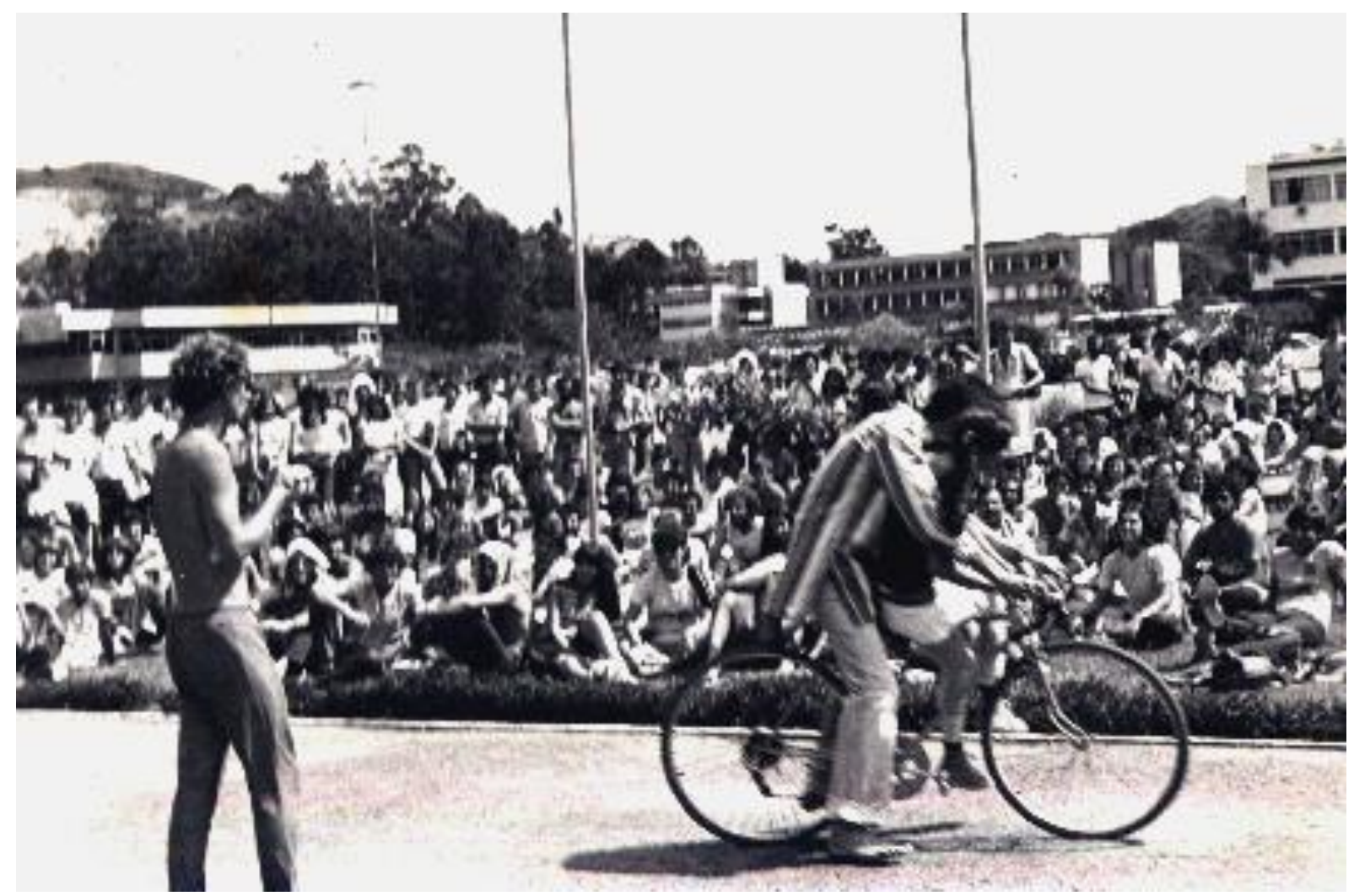

Ney Piacentini, Márlio da Silva e Elisa de Oliveira em O universotário. Grupo A de Teatro.

Campus da Universidade Federal de Santa Catarina, Florianópolis, 1982.

São Paulo

Narrei as passagens acima para que se tenha uma ideia da irregular formação que tive, antes de me mudar para São Paulo. E isso se deu porque Roseli Galleti voltaria à capital paulista, em 1985, trazendo de Santa Catarina algumas pessoas para trabalhar na TV Bandeirantes. Roberto de Oliveira dirigia o programa Oito e meia, de informação com entretenimento, e me incumbiu de fazer algo semelhante aos vídeo-tipos da RBS TV de Florianópolis, porém com uma gag diária de 30 segundos em média, com o mesmo personagem de segunda a sexta. E também eu dirigiria videoclipes, coisa que comecei a fazer no Sul. Estes até que funcionaram, enquanto aqueles naufragaram. Eu não tinha as facilidades de produção de uma cidade menor como antes e a minha insegurança era bem maior. Ou seja, 
meu primeiro trabalho atoral em São Paulo não deu certo. E uma série de enganos se acumulou dali em diante. Com exceção de um outro personagem-boneco: o Zé do Muro ${ }^{6}$, por mim manipulado na campanha política à Prefeitura de São Paulo de Eduardo Suplicy em 1985, que inovava o horário eleitoral no formato e na irreverência. O boneco virou uma atração naqueles meses que antecederam a eleição, talvez porque ele questionava tanto Suplicy quanto Lula e os outros petistas, com perguntas do gênero:

- Ei, Suplicy, você estudou nos Estados Unidos e agora vem com essa de Partido dos Trabalhadores?

- Ô, Lula, é verdade que você é um trabalhador que não trabalha?

E eles davam suas explicações perguntando ao final se o boneco estava convencido, mas eu respondia com uma cara de dúvida em cima do muro. Aqui eu ficara mais à vontade e fui convidado a ir aos comícios com uma enorme resposta do grande público.

De outra parte, uma boa parcela dos atores que trabalharam em São Paulo nas décadas de 1980 e 1990 aderiu à publicidade. E, para tanto, era preciso fazer fotografias e distribuí-las nas agências e aos produtores de elenco. Demorou para eu ser aprovado em algum comercial, mas depois fiz muitos, tendo ainda trabalhado com vídeos institucionais para empresas. Essa frente durou cerca de dez anos e eu não via problemas em ganhar meu sustento como garotopropaganda. Porém algo me dizia que não seria bom chegar aos 40 anos (devo ter pensado isso aos 30-35 anos) em filas de testes para ser avaliado se eu era ou não o perfil do produto deste ou daquele anunciante.

Ao mesmo tempo, enfrentava as dificuldades para se fazer teatro na maior cidade do país. Como havia juntado algumas economias, resolvi voltar à cena fazendo uma pequena peça de esquetes. Ao lado de Artur Khol, sob a direção de Roney Fachinni, preparamos cinco ou seis quadros de humor batizados de Dose duplas. Nessa mesma fase, remontei em São Paulo Vira e mexe e a iniciativa chegou bem ao público e às pessoas de teatro. Mais adiante, em dupla com Luciene Adami, trabalhei na TV Cultura de São Paulo fazendo, como apresentador-ator, o programa Revistinha, colaborando também com os roteiristas e tomando parte nas reuniões de criação. Ele chegou à maior audiência da emissora, ganhou dois prêmios da Associação Paulista de Críticos de Arte (APCA) como Melhor Programa Infantojuvenil de 1988 e 1989 e até um selo especial dos Correios, comemorativo dos 20 anos da TV Cultura,

\footnotetext{
${ }^{6} \mathrm{O}$ personagem-boneco foi criado por Chico Malfatani, produzido por Nabor Prazeres e confeccionado por Diu Rossetti e Fernando Brettas.
} 
foi estampado conosco no cenário do programa. É possível que seu acerto tivesse relação com seus conteúdos e formas educativas e, talvez, com a teatralização que fazíamos como apresentadores jogando ao vivo com uma situação fictícia a cada tarde: um garçom que servia à cliente as atrações que a grade ofereceria, extraterrestres curiosos pelo que seria apresentado, Dom Quixote e Sancho Pança e um incontável número de possibilidades de duplas que explorávamos. Porém, como fazíamos o programa de tarde para noite, não podia fazer teatro.

Decidi então deixar a TV Cultura. Não escondo que, quando depois me faltaram trabalhos, pensei ter me precipitado ao largar um emprego fixo como aquele. E, ao sair da televisão, entrei no Projeto Didática da Encenação, na Oficina Cultural Oswald de Andrade, que, àquela altura (1991), chamava-se Oficina Cultural Três Rios. Edith Siqueira e Lala Deheinzelin, como diretoras, e José Rubens Siqueira, como dramaturgo, tratariam da vida e obra de Oswald de Andrade. Tivemos aulas de corpo e dança com Denilton Gomes e Sonia Galvão, e da minha interpretação não guardo as melhores lembranças. Meu Oswald de Andrade era exagerado, uma vez que eu não soube ser conduzido pela direção de $O s$ ventos $e$ os Waldes ${ }^{7}$.

Mais consequentes foram as iniciativas seguintes. De férias da TV Cultura, havia viajado à Europa e voltara com muitos textos de teatro na bagagem. Entre eles, uma peça radiofônica de Friedrich Dürrenmatt - Crepúsculo de uma tarde de outono -, um outro de Tom Stoppard - O legítimo inspetor perdigueiro - e um terceiro de Jean-Claude Carrière - $O$ catálogo. O primeiro estreamos em 1991, o segundo em 1992 e o terceiro em $1995^{8}$. Não havia um propósito maior em montar essas três obras, a não ser o ímpeto de produzir em grupo e o fato de que os três dramaturgos eram de excelência, embora tematicamente não se

\footnotetext{
${ }^{7}$ Elenco: Adriana Estitte, Alexandre Reinecke, Anton Zacharkow, Aury Porto, Carla Miranda, Chico Villa, Élida Marques, Fernanda Abujamra, Guilherme Freitas, João Paulo Leão, Maria da Paixão, Ney Piacentini, Paulo Faria, Renata Molitzas, Silene Pignagrande, Silvana Scoss, Tereza Marinho, Valdir Rivabem e Waghi de Azevedo; direção de arte: Marcos Botassi; música: Mítar Subotíc (part. especial de: João Parahyba); produção e realização: Abaporu; pesquisa e dramaturgia: José Rubens Siqueira; direção: Edith Siqueira e Lala Deheinzelein.

${ }^{8}$ Ney Piacentini e Roney Fachinni estavam no elenco de Crepúsculo de uma tarde de outono, com a participação especial de Artur Khol, Fernanda Abujamra, Henrique Stroeter, Kaiq Antunes, Patrícia Gaspar e Tânia Boldezan. A direção foi de Márcia Abujamra, a música de André Abujamra, executada ao vivo por Eneida Mônaco e Luis Antônio Ramoska. Os cenários e figurinos foram de Marcos Botassi e a iluminação de Francisco Medeiros. A preparação corporal foi feita por Edu Mota, a assistência de direção de Paulo Faria, as fotos de Lô Assunção e a tradução do espanhol por Fátima Lima. O legítimo inspetor perdigueiro contou com a direção de Eliana Fonseca, com a atuação de Ângela Dip, Antônio Calloni, Ariel Mosche, Carina Cooper, Deni Bloch, Lui Strassburger, Ney Piacentini e Paulo Gandolfi, em São Paulo. No Rio de Janeiro, Carina Cooper foi substituída por Iara Jamra e Lui Strassburger por Marcelo Mansfield. A sonoplastia ficou a cargo de Michael Ruman com música de André Abujamra, a cenografia de Beto Paiva e a tradução de Reinaldo Moraes. A programação visual foi de Emerson Kapaz e as fotografias foram de Nelson Kon.
} 
alinhassem. Na minha trajetória era uma evolução, sem dúvida, tendo em conta que os trabalhos anteriores não possuíam a mesma qualidade. Contudo, Márcia Abujamra, diretora de Crepúsculo de tarde de outono, teve que me corrigir para evitar que eu descaísse em uma caricatura na pele de um fã de um famoso escritor (Roney Fachinni).

Apesar da mão firme de Eliana Fonseca como diretora, eu não consegui evitar que o produtor se sobrepusesse ao ator em $O$ legítimo inspetor perdigueiro. Estava tão atribulado com as precárias condições para viabilizar a empreitada que a minha dedicação à atuação naquele projeto não foi suficiente. Essa dupla função continuou na Companhia do Latão, nos seus primeiros seis anos, em que também fui seu gestor, assim como quando fui presidente da Cooperativa Paulista de Teatro. Somente ao estudar para o mestrado as posturas de Constantin Stanislavski e Eugênio Kusnet, reparei mais claramente que poderia me dedicar muito mais ao trabalho de ator, o que veio reforçar o que já era postulado na Companhia.

Entre Crepúsculo de uma tarde de outono e O legítimo inspetor perdigueiro, fui fazer uma participação em uma telenovela na extinta TV Manchete, de nome Ana Raio e Zé Trovão. Com algumas exceções, entre as cenas que fiz, independentemente dos atributos do roteiro, vi que não sabia atuar em novelas e percebi que, para fazê-lo bem, necessitaria de mais tempo a fim de aprender como me portar naquela linguagem, uma vez que na TV Cultura não acertamos nos primeiros programas. O mesmo se estende ao cinema, que fiz bem menos que gostaria. Nas minhas participações, tirante uma ou outra, faltou-me esquecer da câmera e da equipe em torno do plano em filmagem. Isto é, abster-me do exterior e centrarme nos problemas, pensamentos e atitudes do contexto e do personagem, como se não existisse todo aquele aparato para a captação de imagens e sons.

Em 1994, voltei à Oficina Cultural Oswald de Andrade para integrar o elenco de Alice $^{9}$, por uma ala da Companhia Cidade Muda. O grupo, mais voltado ao teatro de animação, experimentaria uma versão para adultos e com atores do clássico de Lewis Carroll. Mesmo tendo sido interessante fazer o Chapeleiro Maluco e contracenar com colegas talentosos, o projeto não ganhou fôlego, mas gerou um vínculo: foi nesse trabalho que conheci Sérgio de Carvalho, seu dramaturgista que não permaneceu no projeto. No mesmo ano, entrei substituindo João Vitti em Budro, obra premiada de Bosco Brasil, e lamento que a minha memória não alcance as indicações que recebi do breve convívio que tive com o diretor Emílio Di Biase.

\footnotetext{
${ }^{9}$ Elenco: Casé Campos, Joelson Medeiros, Luciana Botelho, Lucia Romano, Miriam Rinaldi, Ney Piacentini e Rodrigo Lopez. Autoria: Lewis Carroll, adaptação: Marco Lima, direção: Marco Lima e Maria Mirtes Mesquita, iluminação: Guilherme Bonfante e Marisa Bentivegna, trilha sonora: Marco Lima.
} 
As conversas com Sérgio de Carvalho iniciadas em Alice continuaram e, no ano seguinte (1995) nos unimos para encenar $O$ catálogo $^{10}$, de Jean-Claude Carrière. Então houve mudanças. Para ficar em apenas uma parcela do trabalho, no começo da peça o meu papel, enquanto tomava seu café, recebia uma visita matinal inesperada de uma mulher (Graziella Moretto). Ao falar com ela, eu girava uma colher na xícara que não continha o líquido de verdade. Sérgio me perguntou quanto café haveria ali dentro e se eu o tinha adoçado com duas ou três colheres. Perguntei se era importante saber aqueles detalhes. Ele respondeu que, conforme as minhas escolhas, eu iria mexer a colher de uma ou outra maneira e em velocidades distintas, já que as quantidades de café e de açúcar mudariam o modo de eu movimentar a colher ao falar com a visitante. Apontou que o que se faz é tão ou mais importante do que o que se diz em cena. Ou seja, eu, como personagem, teria uma preocupação real com aquele gesto enquanto conversava com a mulher (e pensava no que ela me dizia), realizando uma ação psicofísica. Recentemente Sérgio me contou que naqueles dias ele lia Stanislavski pelas manhãs para ensaiar à tarde conosco, uma vez que aquela seria sua primeira direção profisssional. Estávamos começando uma parceria que já ultrapassa vinte anos.

\footnotetext{
${ }^{10}$ Direção: Sérgio de Carvalho, elenco: Graziella Moretto e Ney Piacentini, música de Lincoln Antonio, cenários e figurinos de Fábio Namatame, iluminação de Domingos Quintiliano, programação visual de Emerson Kapaz e fotografias de Nelson Kon.
} 


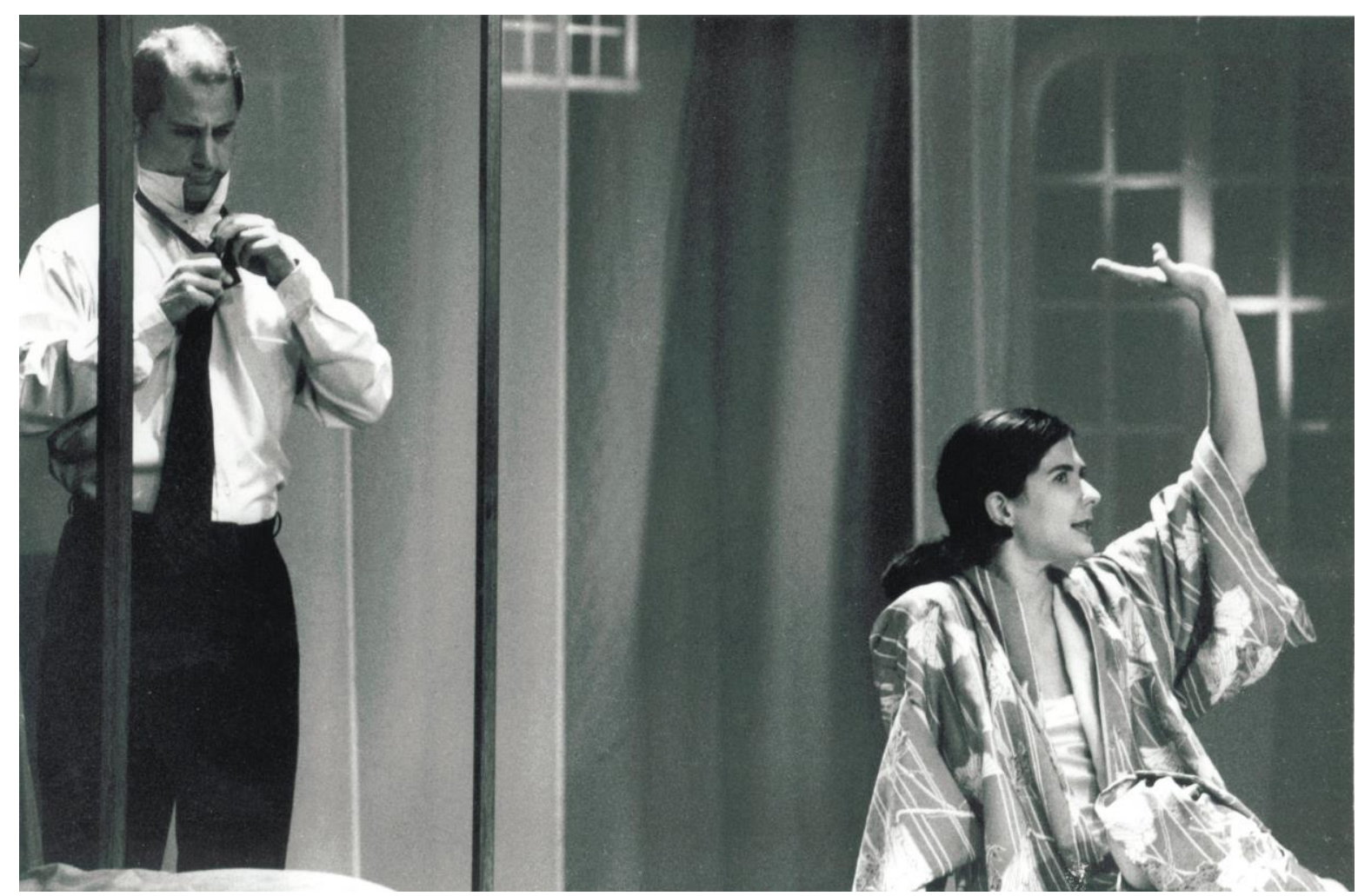

Ney Piacentini e Graziella Moretto em O catálogo, 1996. Foto: Nelson Kon.

Na sequência, em 1986, sob a direção de Lígia Cortez, fizemos a versão teatral de Um céu de estrelas ${ }^{11}$, livro de Fernando Bonassi que já tinha se transformado em um filme. Na peça, eu era um desempregado que não aceitava a separação da ex-mulher (Luah Guimarães) e a prendia dentro de casa, o que acabava em tragédia. Um bom exercício que, de certa forma, dava continuidade ao que fizemos em $O$ catálogo, em termos de realismo e interioridade dos personagens.

Muito bem, feita a aproximação que expõe quão errática foi a primeira metade da minha trajetória, vamos à etapa principal desta pesquisa, que é sobre o trabalho dos atores na Companhia do Latão. Antes, aproximemo-nos de algumas noções de dialética. Segundo o Dicionário Houaiss, genericamente, ela é “oposição, conflito, originado pela contradição entre princípios teóricos ou fenômenos empíricos” (HOUAISS, 2009, p. 579). Ou, simplificando, “[...] é o modo de pensarmos as contradições da realidade, o modo de

\footnotetext{
${ }^{11}$ O elenco era formado por Fábio Nogueira, Luah Guimarães, Maria Eugênia de Domênico, Ney Piacentini e Suely Oliveira. A dramaturgia foi de Fernando Bonassi, Jean-Claude Bernadet, Tata Amaral e Lígia Cortez, que também dirigiu o espetáculo. Na cenografia, Ulisses Cohn; nos figurinos, Atílio Beline Vaz; na iluminação, Ligia Cortez e Tata Amaral; música de Lívio Tratemberg e Wilson Sukorski; Ana Tomaz na expressão corporal e, na divulgação, Célia Vasconcelos.
} 
compreendermos a realidade como essencialmente contraditória e em permanente transformação" (KONDER, 2004, p. 8).

É perceptível que o termo "contradição" esteja presente nas duas definições, sendo isso o que mobiliza os incidentes do mundo, sejam eles concretos ou simbólicos. E esse ângulo nos interessa: aquilo que, por disparidade, movimenta e faz surgir novos olhares sobre os fatos.

Aproximando-nos ainda mais do nosso objeto, extraímos o seguinte segmento do capítulo A dialética no teatro:

O mundo é transformável porque é contraditório. Nas coisas, gentes e acontecimentos, há algo que os faz como são e, ao mesmo tempo, algo que os faz diferentes. Porque coisas, gentes e acontecimentos evoluem, não permanecem estáticos, transformam-se até tornaremse irreconhecíveis. E as coisas tal qual são agora contêm em si - assim, em forma irreconhecível, outras coisas, anteriores, em conflito com as atuais (BRECHT, 1970, p. 195).

O nosso coletivo partiu de entendimentos brechtianos, transmudando-os no intuito de se manifestar sobre "[...] a modernização conservadora no Brasil e o lugar da cultura em um país periférico do capitalismo" (informação pessoal) ${ }^{12}$. Isso se traduziu em uma pesquisa não apenas de linguagem, mas de assuntos que relacionem teatro e sociedade.

Partindo desse universo, irei percorrer os ciclos do itinerário que nos proporcionou compreender a dialética conceitual e praticamente, a fim de discutir sua assimilação pelo nosso círculo cênico, podendo então, a partir daí, aproximar-me do ator dialético na Companhia. Com certeza meu texto é uma visão parcial acerca da verificação de como o grupo vem operando com a atuação, uma vez que se trata apenas do registro de um de seus colaboradores $^{13}$. Saliento que, mesmo com a imprescindível participação dos elencos que trabalharam conosco, do meu ponto de vista, a proposição de pesquisar a contradição nas nossas interpretações partiu de Sérgio de Carvalho e de Márcio Marciano - dramaturgos e diretores da equipe que, com a saída de Marciano do grupo em 2005, teve seu

\footnotetext{
${ }^{12}$ Sérgio de Carvalho, em palestra proferida na Conferência do IFTR - Internacional Federation of Theater Research. São Paulo, 13 jul. 2017.

${ }^{13}$ Pela amplitude do tema, não abordarei a história da interpretação dialética em escala mundial discutindo, por exemplo, o livro $O$ paradoxo do comediante, de Denis Diderot, ou as interpretações dos atores do Berliner Essemble, como Helene Weigel e Ernest Busch. No Brasil, seria preciso ao menos observar as ideias de Augusto Boal sobre a atuação e as peças brechtianas feitas pelo stanislavskiano Eugênio Kusnet, a fim de mensurar a presença da contradição materialista no modo de os atores conduzirem suas criações, o que seria uma pesquisa instigante. Contudo, optei por especular sobre uma entre outras experiências brasileiras de dialetização do trabalho atoral e ainda assim, como não poderia deixar de ser, incompleta.
} 
desenvolvimento com Sérgio. Diante desse painel, coloco-me apenas como um testemunho que viveu as experiências aqui reunidas. 


\section{CAPÍTULO 1 - O APRENDIZADO DIALÉTICO}

Neste primeiro capítulo, vou discorrer sobre o período que abrange a formação da Companhia do Latão e os seus sete primeiros anos de vida, o que significa abordar desde seu espetáculo inaugural Ensaio sobre o latão até Visões siamesas, obra que cruzou Machado de Assis com Bertolt Brecht. Na cronologia do grupo, esse período corresponde aos seus dois repertórios iniciais: o primeiro constituído entre 1997 e 1999 e o segundo entre 2002 e 2005, intercalados por A comédia do trabalho, estreada no ano 2000.

Em 1996, Sérgio de Carvalho reúne um grupo de atores para a feitura de Ensaio para Danton, numa montagem baseada em A Morte de Danton, de Georg Büchner. Algumas características brechtianas apareceriam nesse espetáculo, como o anti-ilusionismo de preparar as cenas às vistas dos espectadores sem o uso de bastidores, narrativas intercaladas aos diálogos e a repetição de uma situação dramática modificadora do comportamento dos personagens. A peça era feita com a plateia dentro do palco e os componentes da caixa teatral (cordas, bambolinas e pernas) estavam a serviço da história, com os atores manipulando-os sob o olhar do público, sendo que as poltronas da plateia vazia funcionavam, a certa altura, como o plenário das discussões entre as tendências da revolução francesa. No entanto, de modo algum a opção estética desviava a atenção da audiência para o principal que eram os embates entre os transformadores da França no final do século XVIII. Esses indicativos que questionavam a forma exclusivamente dramática (linear em termos de tempo e espaço) repercutiriam no que veremos a seguir. E como eu participei somente da remontagem dessa obra em 1999, deixarei para comentá-la mais adiante.

\subsection{OS PRIMEIROS PASSOS DOS ATORES NA COMPANHIA DO LATÃO}

Teatro de Arena (1997-1998)

"Brecht quer que tudo se construa a partir da experiência da separação. E a separação é que vai inspirar a dimensão épica do distanciamento" (BORNHEIN, 1997, p. 4).

Através do Projeto Pesquisa em Teatro Dialético, que ocuparia por dois anos, via um edital público, o Teatro de Arena Eugênio Kusnet em São Paulo, a Companhia do Latão passou a operar com esse nome. Entre as frentes de trabalho estavam a publicação de um periódico - a Revista Vintém -, um núcleo musical, outro de dramaturgia e a produção de experimentos e espetáculo teatrais A Revista Vintém, editada por Sérgio de Carvalho e parceiros (Cláudia Mesquita, Kil Abreu, Márcio Marciano, Lauro Mesquita, João Carlos 
Guedes da Fonseca e Lia Urbini) encontra-se até o momento em seu sétimo número e a ela se somaram outras publicações: os jornais $O$ Sarrafo (nove números) e Traulito (oito números). O núcleo musical é um dos alicerces do grupo, tendo produzido não só as canções e sonoridades das nossas montagens, como também quatro CDs: Canções de cena I, II, III e Ópera dos vivos. O núcleo de dramaturgia confeccionou sete textos originais: $O$ nome do sujeito, A comédia do trabalho, Auto dos bons tratos, O mercado do gozo, Ópera dos vivos, Os que ficam, $O$ pão e a pedra, e publicou seis livros: $O$ nome do sujeito, Caderno de Apontamentos de A comédia do trabalho, Companhia do Latão 7 peças, Introdução ao Teatro Dialético, Atuação crítica e Ópera dos vivos. Já a frente de produção de espetáculos levantou treze peças: Ensaio para Danton, Ensaio sobre o latão, Santa Joana dos Matadouros, O nome do sujeito, A comédia do trabalho, Auto dos bons tratos, O mercado do gozo, Equívocos colecionados, Visões siamesas, O círculo de giz caucasiano, Ópera dos vivos, O patrão cordial e $O$ pão e a pedra, e doze experimentos cênicos: Lorca-Dali-Buñuel, Memórias da meninice, João Fausto, Homenagem aos trabalhadores de Eldorado dos Carajás, Valor de Troca, Ensaio da Comuna, O grande circo da ideologia, Café/Revolução na América do Sul/Marighela, Frida a foca, Entre o céu e a terra, Os que ficam e Experimento $H$. A frente de vídeo e cinema deu suporte aos espetáculos $O$ círculo de giz caucasiano e Ópera dos vivos, e ao experimento Entre o céu e a terra, tendo ainda lançado três DVDs: Experimentos videográficos da Companhia do Latão I e II e Ópera dos vivos. A pedagogia fez parte das atividades paralelas do grupo desde o seu início, com incontáveis oficinas ministradas em diversas localidades do país.

De modo que, no emblemático espaço do centro de São Paulo, o Teatro de Arena, tendo como guia os escritos de A compra do latão, em que Bertolt Brecht expõe sua teoria e poética teatral, enredamo-nos em nossas primeiras buscas que resultariam em Ensaio sobre o latão, a primeira peça do grupo ${ }^{14}$.

Quando nos reunimos com os atores (grupo formado por remanescentes de Ensaio para Danton, espetáculo anterior ao atual projeto de pesquisa, que já lidava com um tipo de

\footnotetext{
${ }^{14}$ Elenco: Edgar Castro, Gustavo Bayer, Maria Tendlau, Ney Piacentini, Otávio Martins, Vicente Latorre; participações eventuais de Deborah Lobo, Francisco Bruno, Georgette Fadel e Heitor Goldflus na temporada de 2000; música: Walter Garcia; preparação corporal: Fernando Rocha; iluminação: Wagner Pinto e Paulo Heise; cenografia e figurinos: criação coletiva; escrito com base nas improvisações dos atores Gustavo Bayer, Maria Tendlau, Ney Piacentini, Otávio Martins, Edgar Castro e Vicente Latorre; dramaturgia: Sérgio de Carvalho e Márcio Marciano, a partir do texto teórico A compra do latão, de Bertolt Brecht; direção: Sérgio de Carvalho e Márcio Marciano.
} 
interpretação baseada na técnica narrativa, e alguns novos integrantes), percebemos que seria útil desenvolver um trabalho prévio voltado para a integração do grupo.

Realizamos vários experimentos cênicos, amparados nas ideias de Brecht, com o objetivo de estabelecer um discurso a atores e demais participantes do projeto. Essas experiências, realizadas sob a supervisão dos músicos e do preparador físico que integram o núcleo de pesquisa, vêm dotando o elenco de um repertório mínimo indispensável à continuidade dos trabalhos.

Nosso objetivo é despertar nos atores a predisposição ao debate. Estimular neles o distanciamento crítico constante em relação às cenas improvisadas. Colocar em discussão permanente sua opção ao narrar um acontecimento. Interessa-nos promover a mudança sistemática do enfoque a partir do qual os atores constroem suas representações para que, deste modo, possam superar esquematismos. As contradições dos personagens devem ser apresentadas enfaticamente. Nas cenas estudadas, os aspectos obscuros ou tidos como secundários também devem ganhar destaque.

Apresentamos aos atores fragmentos do texto de Brecht somente após a realização de exercícios improvisados. Desta forma, questões teóricas vieram ao encontro da experimentação (MARCIANO, 1997, p. 38-39).

O que Márcio Marciano, então parceiro de Sérgio de Carvalho na dramaturgia e na direção do grupo, apontou sobre aqueles incipientes ensaios é algo como procurar a noção de conjunto - a afinidade entre o elenco, todavia com um propósito: que nós nos acostumássemos a também narrar, além de dramatizar, fatos e acontecimentos com determinado ponto de vista e que tivéssemos consciência disso. E se o conseguíssemos, buscaríamos as oposições nos papéis, mesclando uma atuação paradoxal sobre os personagens aliada às narrativas sobre eles e sobre o contexto da cena. Para isso, uma fonte recorrente nessa fase inicial foram as observações nas redondezas do teatro:

Ali começaram os exercícios de observação do que vinha da cena de rua do Brecht ${ }^{15}$. Fazer uma descrição de uma imitação, a mais precisa possível, com as contradições que a imitação tem, pode funcionar como uma citação, o que já tem diferença da representação dramática tradicional. Improvisar uma cena tentando imitar o que você vê na rua é diferente do que fazer um personagem só a partir do seu repertório pessoal. Vimos que as cenas de rua eram muito melhores do que as que inventávamos porque eram mais contraditórias, mais dadas. Nós ficávamos em mil rodeios para mostrar uma coisa que é óbvia e olhando as coisas acontecendo lá fora tudo era mais simples e mais vivo. Eu, que estava fazendo o papel de Ofélia, via na rua uma menina paquerando um cara na porta de um bar e mexendo

\footnotetext{
${ }^{15}$ Sobre o teatro cotidiano, poesia em que o dramaturgo recomenda aos atores que observem o teatro espontâneo que é praticado nas ruas. BRECHT, Bertolt. Poemas 1913-1956. São Paulo: Editora 34, 1990, p. 235-238.
} 
no cabelo. E olho que ela não fala que está paquerando, mas dá para ver que sim pelo jeito com que ela mexe no cabelo. E o que ela diz? Então você vai juntando aquilo com o Hamlet, contrapondo as coisas, em comparações. Quer dizer, colocar uma situação e sobrepô-la a outro texto, são duas fontes distintas. É diferente porque você vê as coisas em camadas e uma atrita na outra, o que pode causar um sentido novo (informação pessoal) ${ }^{16}$.

Maria Tendlau citou Hamlet porque Shakespeare foi outra referência proposta por Brecht em A compra do latão, a qual adotamos para o trabalho, assim como as incursões à rua.

Queríamos dar forma aos conteúdos teóricos do texto do dramaturgo alemão que colocava em debate a visão de um filósofo visitante de uma companhia teatral com o que pensavam o diretor, os atores e os técnicos sobre a função da arte e do teatro. O filósofo se baseava no materialismo ${ }^{17}$ para defender seus argumentos, enquanto a equipe teatral tinha no fazer artístico um fim em si mesmo ao postular a arte pela arte. Na nossa adaptação, o diretor daquela companhia assumia o ponto de vista do filósofo, enquanto os atores se contrapunham a ele. O cunho não era simplesmente teatralizar os escritos de Brecht, uma vez que eles não tinham uma forma dramatúrgica a ser transposta para o palco, mas mesclá-los com nossas incipientes ideias sobre teatro dialético. Assim, sob a orientação dos diretores Márcio Marciano e Sérgio de Carvalho, nós, atores, nos lançamos em exercícios que partiam das indicações do livro de Brecht, como a sobreposição de cenas de Hamlet às observações de rua.

Em outro momento da pesquisa, a provocação da direção passou a ser uma frase modelar: "O olho produz: belo é resolver dificuldades" $"$. Com essa sentença em mente, em duplas ou trios, o elenco percorria as ruas e praças do deteriorado centro de São Paulo, observando a vida das pessoas. Havia lá um enorme contraste entre a precariedade dos mendigos, bêbados e prostitutas e a sólida arquitetura da megalópole rica e miserável. Como voltávamos ao teatro e contávamos o que tínhamos visto, algumas dúvidas começaram a aparecer: a serviço de que estavam as narrativas? Para que, afinal, relatar ao invés de colocar em diálogos uma cena observada? Por meio desses questionamentos, fomos percebendo formas distintas de narrar, conforme as particularidades dos acontecimentos vistos fora do

\footnotetext{
${ }^{16}$ Maria Tendlau, em depoimento a Ney Piacentini, em 12 mar. 2014.

${ }^{17}$ Corrente da filosofia oposta à metafísica, cujo fundamento é a economia como base para as relações sociais e que pensa a história sendo movida pela luta de classes.

${ }^{18}$ A expressão "O olho produz: belo é resolver dificuldades" foi inspirada na frase "A beleza na natureza é uma qualidade que dá aos sentidos humanos a oportunidade de serem hábeis", que faz parte do livro A compra do latão, de Bertolt Brecht (Lisboa: Vega, 1999, p. 65).
} 
teatro e também que seria recomendado saber para quem se descreve e ainda escolher uma ótica, uma posição a ser tomada. Porém, e principalmente, atentar para as causas dos fatos, o que estaria em sua origem.

Com o passar dos dias, essa junção de fragmentos de rua com trechos de Hamlet começava a frutificar: o ator Vicente Latorre trouxe a invisibilidade de um catador de latas e a associou ao fantasma do pai de Hamlet. A gravidade com que ele narrava como ninguém prestava atenção ao catador enquanto ele mesmo imitava o homem que tinha visto, desacostumava um fato costumeiro, com Latorre proferindo as palavras: "A praça fervilhava de gente e ninguém olhava para ele. Ele era como um vulto, uma sombra: Ninguém olhava para ele" (CARVALHO, 2009, p. 275).

Doutra sorte, Edgar Castro, Gustavo Bayer e Otávio Martins trouxeram uma conversa com uma prostituta que eles encontraram em um bar perto do teatro. A cena mostrada causou espécie no restante da equipe que a assistia. Alternadamente os atores narravam sobre aquela mulher, representavam a si mesmos, faziam perguntas a Sandra e assumiam o papel da prostituta. O efeito no espectador por vezes era cômico, mas não de um riso fácil. E o que vale lembrar, apesar da inventiva forma por eles encontrada, é que em nenhum momento esse feito furtou o esfacelado estado de vida daquela mulher.

Pois não havia uma combinação de tentarmos criar um código gestual único para a Sandra. O Otávio fazia a Sandra que ele via, o Bayer fazia a Sandra que ele via e eu fazia a Sandra que eu via. E era a mesma figura vista por três perspectivas diferentes, cada um enxergando e reorganizando o discurso cênico à sua maneira. Acho que chegamos àquela estrutura, do personagem transitar pelos três atores, pela solidão. Tinha muita solidão nela. Uma figura cheia daquelas histórias e um ser extremamente só. Partimos disso, do problema, do assunto, do conteúdo e depois, pensando em como iríamos elaborar aquele encontro colocamos, como centro organizador da cena, o próprio ator. Na verdade, éramos três atores narrando aquele episódio (informação pessoal) ${ }^{19}$.

Não é possível descrever a riqueza tragicômica resultante do que Edgar Castro reconstituiu. Mas, nessa cena, foi possível perceber um encaixe entre o que a direção nos pedia e o que os atores encontraram: observar a realidade, narrar diretamente para o público assumindo um ponto de vista, vivenciar personagens contraditórios em improvisações a serviço da construção da dramaturgia e encontrar formas humanizadoras dos temas em curso.

\footnotetext{
${ }^{19}$ Edgar Castro, em depoimento a Ney Piacentini, em 23 maio 2014.
} 


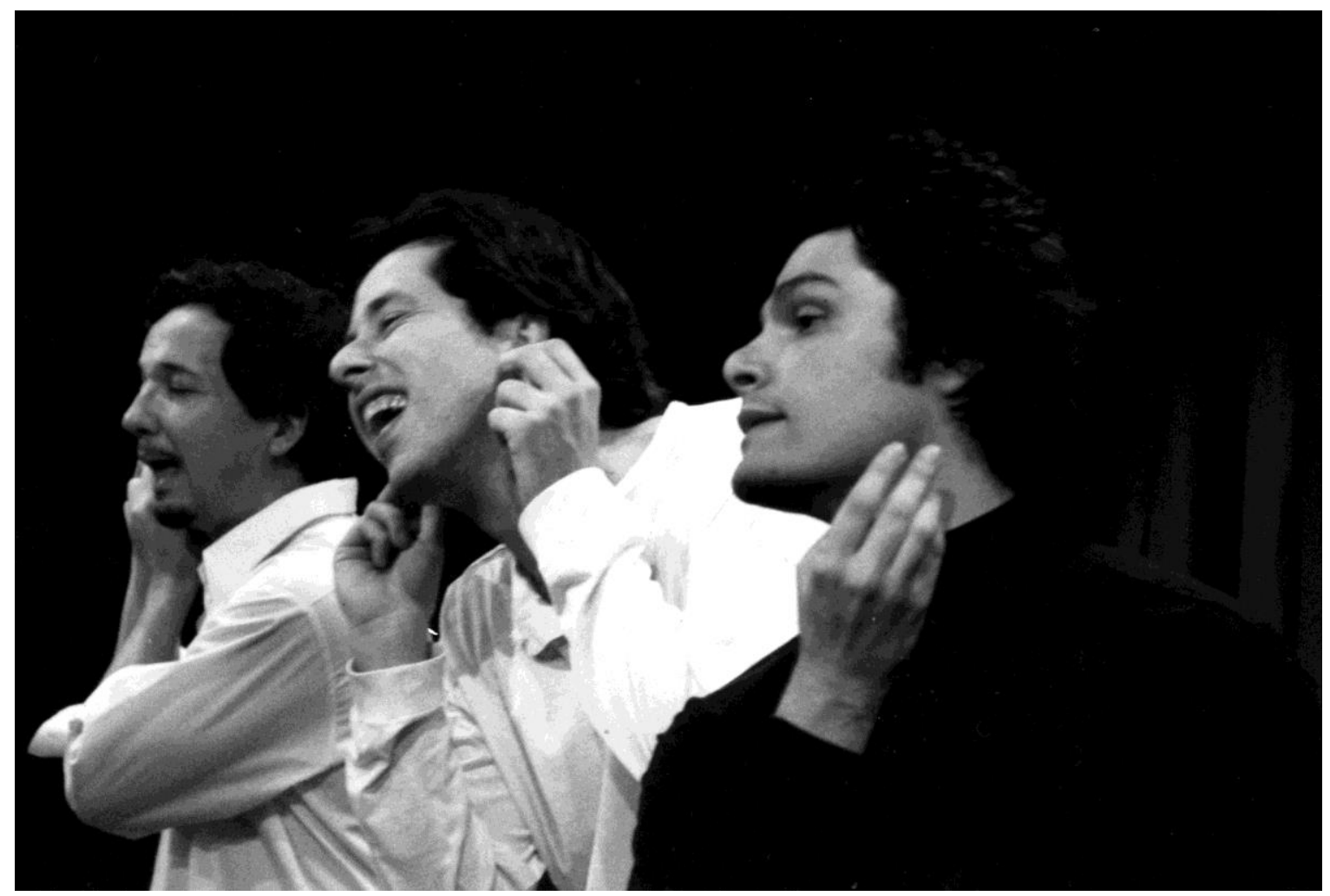

Edgar Castro, Otávio Martins e Gustavo Bayer na cena da Sandra. Ensaio sobre o latão, 1997. Foto: Belfort-Rodrigues.

O entrelaçamento nessa cena pode ser estendido a Ensaio sobre o latão como um todo, visto que a montagem não era linear. Suas partes se dividiam em quatro noites de ensaios e, se na primeira o público assistia a um híbrido entre cenas clássicas (Hamlet) com as observações de rua, ao final da segunda noite a equipe encenava uma adaptação do poema Sobre o teatro cotidiano, de Bertolt Brecht. O problema aqui era um acidente de trânsito e seus ângulos. Pantomima, gestos largos e caricaturas foram utilizados para mostrar como um evento pode ser mudado, dependendo de quem o conta. $\mathrm{O}$ tom anedótico servia para colocar em discussão os diferentes argumentos de cada um dos envolvidos no episódio. Passo a passo, íamos testando variados recursos, a fim de entendermos melhor como promover o estranhamento brechtiano, que tem como uma de suas finalidades um melhor entendimento das relações retratadas na obra.

Desde o início das nossas atividades, o efeito do distanciamento esteve em pauta no grupo. O problema foi elucidar o que para nós seria a paradigmática formulação do autor alemão. Entre conversas e as práticas de palco, foi adotado um conceito de que distanciar é desnaturalizar um acontecimento. A ordem das coisas no mundo não é natural, possui causas históricas, está inserida em um contexto social e existem sujeitos que fazem com que elas se apresentem de uma determinada maneira ou de outra. Outros agentes, que tenham 
discordâncias sobre esta ou aquela visão, podem fazer com que os valores sejam diferentes dos estabelecidos. Assim, pela nossa leitura, distanciar não seria apenas sair do personagem e comentá-lo via uma narrativa, mas também poder contestar um fato tido como incontestável, questionar o porquê da dominação de uns sobre outros, ou seja, politizar a cena com o intuito de desabituar as relações que estão fora do teatro. Os meios para se atingir tal fim estavam sendo investigados em exercícios e, gradativamente, começaram a aparecer.

Entre nós, um modo inusual de provocar o afastamento foi experimentado a partir de um episódio real por ocasião de uma visita de uma equipe de televisão, que foi ao Teatro de Arena fazer testes com os atores. Dias depois improvisamos a disparidade entre os interesses do assistente de direção da TV (vindo ao grupo em busca de tipos que servissem aos seus propósitos) e o momento do elenco da companhia imerso nas cenas de Hamlet. Com isso, entravámos na terceira parte da peça. Eu representava o assistente exagerando seu apego a detalhes visuais e o seu desprezo pelo desempenho artístico dos atores. Enquanto estes se concentravam em defender os textos que haviam preparado para a câmera, o assistente prestava atenção aos atributos físicos dos intérpretes. Cada intervenção do homem de televisão, cortando as cenas abruptamente, pedindo que um ator desse o seu perfil para ser gravado ou reparando na cor dos olhos de uma atriz, gerava um modo particular de distanciamento. O elenco também propunha distorções em seus desempenhos, por vezes não diferenciando o que era um texto e o que era uma fala do próprio ator. Vicente Latorre, que fazia o fantasma do pai de Hamlet, confundia as frases do papel e dizia ao final: "Escuta, escuta [fala do fantasma]... esqueci o texto!” (fala do ator - dita com a mesma verve de “Escuta, escuta...”). Maria Tendlau colocava um lacônico "acabou”, cortando secamente a comoção de Ofélia diante do pai morto. Otávio Martins chegava ao ponto de se esconder atrás da cortina para representar a morte de Polônio, deixando o assistente de TV perplexo em só ouvir a voz do ator oculto atrás dos panos. Edgar Castro tinha que, a um pedido meu por uma opção de tipo regional, fazer um sotaque nordestino. Toda essa série culminava no ator Gustavo Bayer, irritado com as diversas interferências que sofria em sua tentativa de realizar o monólogo "Ser ou não ser" de Hamlet, indo para cima do assistente, transformando o texto de Shakespeare em uma forte reação à postura daquele intromissor. As palavras do famoso monólogo viravam uma arma para Bayer: "[...] e os insultos que os mais pacientes toleram de gente indigna, que poderia se aquietar na ponta de uma faca!” (CARVALHO, 2009, p. 290291).

Assim terminavam as frases de Hamlet com Gustavo vociferando contra o representante da emissora. A metateatralidade, com o elenco representando a si e aos 
personagens e os momentos em que eu me voltava para o público não como assistente e sim fazendo comentários narrados em terceira pessoa, era crítica em duas pontas: tanto os atores não correspondiam às exigências televisivas ao recitarem textos clássicos, quanto o assistente os via somente como possíveis produtos para os seus objetivos. Dessa maneira, não nos limitamos a jogar com o teatro dentro do teatro, porém fornecíamos mais de um ângulo para os espectadores fazerem suas escolhas.

Podemos dizer que essa foi a tônica atoral de Ensaio sobre o Latão: deslocar os meios do distanciamento de Brecht para o nosso contexto a fim de que o espectador tivesse mais clareza sobre os motivos da obra. Colocamos sim em prática a interrupção do fluxo dramático para comentar diretamente ao público o episódio que estava sendo dramatizado, como eu fazia com meu assistente de direção, depois dos testes por ele dirigidos: "Naquele momento, o assistente se perguntou sobre o sentido desse tipo de representação" (CARVALHO, 2009, p. $286)^{20}$, entre mais exemplos. Porém, novas formas de estranhamento vieram à tona, como a já citada sóbria narrativa de Vicente Latorre ao descrever os gestos e atitudes do catador. $\mathrm{O}$ ator pouco se curvava para lembrar o homem que pegava latas abandonadas nas ruas, invisivelmente amassando-as com os pés e as colocando dentro de um saco. Assim, transmitia um incômodo que fazia com que quem o visse não aceitasse aquela situação já banalizada nos dias atuais. Ou seja, a maneira como a cena foi representada pelo ator produziu um reflexo de inconformismo com o estado a que chega um homem que sobrevive do recolhimento de lixo das ruas.

Ao final do espetáculo, irrompia no espaço o iluminador do teatro, declarando não ter muito tempo a perder para fazer a sua parte. O técnico veria a movimentação da trágica cena do fim de Hamlet, cujos confrontos levam os personagens à morte, e prepararia sua luz. Por uma teatralidade que colocava em paralelo os atores contando ao iluminador o desenrolar da situação da peça com trechos em que passavam da narrativa à ação e ainda com interrupções por parte do técnico, que se movimentava no teatro com sua escada para posicionar os refletores - o que se via era a reprodução de um ensaio para a iluminação. Porém o intuito, nesse caso, não era mostrar como se utilizava o equipamento, mas promover o distanciamento através do olhar de alguém de fora da obra (o técnico de luz). $\mathrm{O}$ atrito entre os momentos em que os atores partiam para executar os tensos duelos entre os personagens (sendo que estes eram indicados apenas, tendo cabos de vassoura como espadas) e a objetividade com que o

\footnotetext{
${ }^{20} \mathrm{Em}$ Escritos sobre teatro, Brecht aponta que o distanciamento pode ser obtido com: "O traslado para a terceira pessoa; o traslado para o passado; a inclusão (em voz alta) de citações e comentários" (Buenos Aires: Nueva Visión, 1973, p. 172).
} 
iluminador os interrompia, produzia dobras no desenrolar da cena, as quais deslocavam o olhar do espectador dos instantes dramaticamente carregados para a realidade física da própria arquitetura teatral em que estavam. Revelava-se a manipulação dos refletores, as varas que sustentavam as luzes e os cabos elétricos subtraindo a plateia da ilusão artística teatral, proporcionando-lhe uma ótica divergente da convencional.

“A graça desse experimento é mostrar para o público de que forma a criação se transforma sob o influxo de um propósito. Quando alguém se pergunta por que se representa, as cenas adquirem consistência e poder de comunicar" (LIMA, 1999, p. D30).

Como escreveu a crítica, Ensaio sobre o latão questionava a função da arte, se não vejamos as belas palavras que o personagem do diretor emitia a certa altura da peça:

Tenho uma curiosidade infinita pelo homem. Vê-lo, ouvi-lo. Me interessa a forma como os homens se tratam. O modo como vendem cebolas, como planejam suas guerras, como decidem seus casamentos. Como observam o céu. Como se enganam, se exploram, se julgam. Porque me pergunto como devo eu me comportar para ser tão feliz quanto possível. E sei que isso depende também da forma com que os outros se comportam. Por isso me interessa também a possibilidade de influir sobre os demais (CARVALHO, 2009, p. 273).

E também:

Imaginem um comerciante de Latão que um dia vai visitar uma banda de música. Ele vai lá, não para comprar o instrumento, mas o latão. O instrumento é feito de lata, mas há pouquíssima chance de o instrumentista querer vendê-lo pelo preço do quilo do latão. Eu, assim como esse comerciante, estou à procura da matéria dos acontecimentos que se produzem entre os homens (CARVALHO, 2009, p.273).

Este é o trecho que inspirou o nome do grupo e, naquele começo de existência, costumávamos usar uma expressão para definir o nosso projeto: diversão com reflexão. E o público de Ensaio sobre o latão era recebido como se fosse novos atores da Companhia naquele nosso primeiro experimento, já que queríamos dele uma maior participação, sem que isto o obrigasse a interagir com a cena. Uma cooperação imaginária, pelo prazer de ativar o entendimento.

Santa Joana dos Matadouros (1998) 
O assunto é a crise do capitalismo, cujo ciclo de prosperidade, superprodução, desemprego, quebras e nova concentração do capital determinam as estações do entrecho. As personagens são a massa trabalhadora, empregada ou desempregada, os magnatas da indústria da carne, os especuladores, e - disputando as consciências - os comunistas e uma variante do Exército da Salvação (os boinas pretas). Servem de lugar os matadouros de Chicago, o edifício da bolsa de valores e o quartel dos soldados de Deus (SCHWARZ, 2001, p. 7).

Na segunda peça da Companhia do Latão, contamos a história de Joana Dark, uma religiosa disposta a fazer o bem aos prejudicados pela crise de 1929 nos Estados Unidos. Em suas andanças ela aprende, nos abatedouros da capital do estado de Illinois, como agem os poderosos da fabricação da carne enlatada, em meio aos efeitos da depressão econômica. Entre eles, Pedro Paulo Bocarra, o graúdo entre os industriais que aplicavam na Bolsa de Valores. Outra figura de destaque nesse painel era a Senhora Luckernidle, uma mulher que procurava pelo seu marido operário desaparecido.

O nosso transcurso para esse clássico de Brecht se iniciou com leituras do texto visando a formação política dos integrantes do grupo, uma vez que Santa Joana dos Matadouros contém alguns dos principais conceitos da dramaturgia brechtiana, tais como a influência marxista reveladora do modo de produção capitalista. Se alguns de nós tínhamos algum conhecimento sobre a temática, com as noções de economia que nos forneceram, passamos a compreender um pouco mais a respeito de como a classe dominante maquina os meios produtivos e gera o capital excedente através da mais valia, explorando o trabalho dos assalariados.

Em paralelo aos estudos de compreensão da obra, nas leituras foram sendo corrigidos pela direção alguns equívocos que nós, atores, cometemos quando começamos a ler uma peça teatral. Ao invés de darmos atenção ao que está acontecendo no contexto da história, é comum que imprimamos ou velocidade, ou emoção ou entonação aos personagens, em uma espécie de demonstração precoce de que já estamos envolvidos com os papéis.

$\mathrm{Na}$ Companhia do Latão, aprendemos que antes de tudo é preciso entender a fábula, o enredo, o que está sendo contado e isso muitas vezes pede um estudo que se atenha ao sentido do texto e que dispensa a atuação precipitada sobre a obra. Não que não se possa desenhar a voz ou variar seu timbre ou o ritmo em leituras, porém, numa primeira etapa, a prioridade é o discernimento do que está posto pela dramaturgia.

Após alguns ensaios fechados, abrimos as nossas investidas ao público às sextasfeiras, sendo que a cada semana experimentávamos encenar uma nova parte do texto. Via de 
regra, essas leituras abertas eram feitas em pé (e não com o elenco sentado a uma mesa), com os textos nas mãos, exceto naquelas cenas em que já havia algum esboço de teatralização. Na medida em que fazíamos mais apresentações, novas partes da peça dispensavam os roteiros. As passagens do que era lido às encenações não foram simples e imediatas para os intérpretes, visto que geralmente ou se lê ou se encena uma dramaturgia. A nós foi proposta pela direção uma instância intermediária que chamamos de leitura encenada. A dificuldade para os atores se situava justamente no momento em que deixávamos o texto de lado e passávamos a atuar. A ansiedade de representar, enquanto líamos, fazia com que perdêssemos, por vezes, o significado das cenas. Para nisto não resvalar era preciso concentração e a percepção do que estava sendo posto, sem uma preocupação em pré-atuar. A própria leitura levaria ao conhecimento das cenas pelos atores e, assim, o público poderia acompanhar os episódios da peça.

Não demorou muito e Santa Joana dos Matadouros foi levada ao palco em sua inteireza. Sem dúvida que o trabalho anterior nos forneceu uma aproximação a formulações como a da desnaturalização: "Uma das razões da glória que Marx atribuía a si mesmo era ter explicado que o capitalismo não correspondia à natureza humana, mas que ele correspondia a uma formação histórica que tinha começado num certo momento e que, com sorte, em algum momento iria terminar" (SCHWARZ, 1997, p. 29).

Entretanto, ao mostrarmos aos espectadores um espetáculo teatral, novos problemas surgiram. O cinismo de Pedro Paulo Bocarra - industrial e investidor da Bolsa de Valores -, agradava mais o público do que as buscas de Joana Dark, a missionária. Mudamos, de acordo com as constatações dos dramaturgos-diretores, quatro vezes os originais, até chegarmos a um modo que desmascarasse as desastrosas consequências que as manobras dos ricos acarretavam aos de baixo. Entre as alterações estavam a troca de ordem das primeiras cenas, com Joana abrindo a peça e não com Bocarra e seus comparsas. Isto para evitar a empatia para com o sarcasmo do astuto proprietário e fazer com que os espectadores entrassem na história seguindo Joana e os religiosos. Era uma aposta para que o público acompanhasse os esforços da jovem missionária em fazer o bem e se afastasse da sedutora argúcia de Bocarra e companhia.

Às vezes, a gente, por exemplo, favoreceu certa identificação do público com o indivíduo Joana, mais do que o texto pedia. A ideia era tornar o impacto mais forte depois, quando a Joana cumpre a trajetória de aprendizado dela. E isso nasceu da nossa experiência com a peça, porque fizemos o espetáculo em muitas cidades e fomos percebendo que isso deixava o texto mais vivo (CARVALHO, 1988, p. 3). 
Em outra alteração, no meio do espetáculo, a direção intercalou a especulação na Bolsa de Valores com a penúria dos desempregados e isto culminava na morte da Senhora Luckernidle (esposa de um trabalhador desaparecido), em uma correspondência na qual se associava os golpes acionários a seus efeitos danosos nos operários.

“'Santa Joana 5' ganha em clareza e perde em humor” (SÁ, 1998, p. 5-6), registrou o jornal Folha de S.Paulo, confirmando que as nossas opções foram acertadas, apesar da desaprovação do crítico, já que o objetivo não era dar vazão à desfaçatez social imperante no final da década de 1990. O rebatimento dessas mudanças se deu também espacialmente: passamos a ir ao encontro do público no saguão do teatro como missionários, depois fazíamos uma cena na lateral do prédio - com um coro de trabalhadores ameaçando deixar a fábrica pelos baixos salários, para então os espectadores ficarem dentro do palco onde presenciavam a movimentação da Bolsa de Valores. Somente quando Bocarra dialogava com Cridle (um outro industrial) é que o público se dirigia à plateia e assim se estabelecia a relação tradicional entre a função e os espectadores.

Quanto à atuação, ouçamos Déborah $\operatorname{Lobo}^{21}$ a respeito de sua aproximação ao teatro épico e ao seu personagem.

Eu era uma atriz exclusivamente dramática, acostumada a decorar textos e seguir as marcações. No entanto, no Latão a cena era construída conforme o que cada ator levava. Tínhamos que defender um ponto de vista sobre determinado assunto e sermos responsáveis pelo que fazíamos. A minha Joana exigia uma interpretação mais verdadeira e era preciso defender aquela ingenuidade. Mas eu imprimia uma emoção antes de entender qual seria a estratégia, o enfoque a adotar com o personagem. E isso, não pensar em outras abordagens, diminuía a riqueza do papel. Gradativamente, a direção e eu fomos encontrando os meios de incorporar todos esses aspectos (informação pessoal) ${ }^{22}$.

Os dizeres de Déborah contêm um aprendizado que, a meu ver, é gradual, pois a apreensão do que vemos como uma interpretação épico-dialética não depende de técnicas, porém de um pensar, agir e se comportar que tenham como propósito transformar o meio em

\footnotetext{
${ }^{21}$ Elenco de Santa Joana dos Matadouros: Deborah Lobo, Edgar Castro, Georgette Fadel, Gustavo Bayer, Maria Tendlau, Otávio Martins, Ney Piacentini e Vicente Latorre; música: Walter Garcia e Fernando Rocha, com a colaboração dos atores; direção musical: Lincoln Antonio; cenografia e figurinos: Márcio Medina; iluminação: Paulo Heise e Wagner Pinto; direção técnica: Francisco Bruno; produção: Ney Piacentini, Tatiana Weberman, Juliana Pinheiro, Mirela Gorenstein; adaptado da peça de Bertolt Brecht (1898-1956); tradução: Roberto Schwarz; adaptação e direção: Sérgio de Carvalho e Márcio Marciano.

${ }^{22}$ Déborah Lobo, em depoimento a Ney Piacentini, em 27 jun. 2013.
} 
que vivemos, o que passa por mudanças em nós mesmos, para ficarmos em um alcance modesto, já que Marx e Brecht almejavam muito mais.

No que diz respeito à representação de Bocarra, havia uma particularidade: ele falava do processamento industrial de enlatar carnes como se fosse alta poesia:

\author{
Lembra-te, ó Cridle, o dia \\ Em que percorrendo o matadouro - era noite - \\ Paramos ao pé da máquina de enlatar presunto? \\ Lembra-te, ó Cridle, aquele vitelo \\ que virava o olho claro, grande e obtuso para o céu \\ Enquanto entrava na faca? \\ Senti como se fosse carne \\ Da minha carne \\ Ai de nós Cridle, como é sangrento o nosso comércio (BRECHT, 1996, p. 15).
}

Isto era insólito por fundir duas vias opostas, o violento mundo dos matadouros ("Enquanto entrava na faca?”) a uma poesia que tinha algo de clássica (“[...] que virava o olho claro, grande e obtuso para o céu [...]"). E ainda por imprimir uma dubiedade entre sentimento e insinceridade no maioral entre os negociantes (“[...] Ai de nós Cridle, como é sangrento o nosso comércio"). Gustavo Bayer, o ator desse papel, emocionava-se ao declamar tais versos o que levava o público a receber aquilo como esquisito, causando estranhamento e então se instalava o distanciamento. Quero dizer, os espectadores desconfiavam se o personagem estava sendo honesto ou não e, com a sagaz inflexão da interpretação de Bayer, via-se em seguida que se tratava de um artifício - falsear sair dos negócios dos matadouros - para mexer nos preços do mercado acionário e assim ganhar bem mais. Tal modo de manejar com esses antagonismos - estilo helênico e assunto rebaixado - seria assimilado em outros dos nossos projetos, como A comédia do trabalho e Ópera dos vivos ${ }^{23}$.

\footnotetext{
${ }^{23}$ Limitando-me a uma só amostra, reproduzo uma passagem de Ópera dos vivos, relativa ao cruzamento de um assunto ordinário em estilo elevado, no qual eu narrava: "Ó grande tela! Revelai seus segredos intactos. Belo neste mundo é tudo o que pode ser reproduzido pela câmera! Que se veja uma gigantesca torre e se intua seus sinais invisíveis transformando-se em ideais no céu da cultura! Inicia-se a jornada na maior emissora do país: a TV Todo! Maquiadores, maquinistas, carregadores de cenário, rebobinadores de fitas magnéticas. Vemos seus músculos, suas veias, como em uma batalha campal! Que se vislumbre mais ao fundo a estrutura de uma cozinha industrial: abrem-se as portas de uma geladeira frigorífica! E ao fundo, reparem, uma mulher contempla sua própria imagem na superfície de uma panela de aço inox!" (CARVALHO, Sérgio de. Ópera dos vivos. São Paulo: Expressão Popular, 2014, p. 124-25).
} 


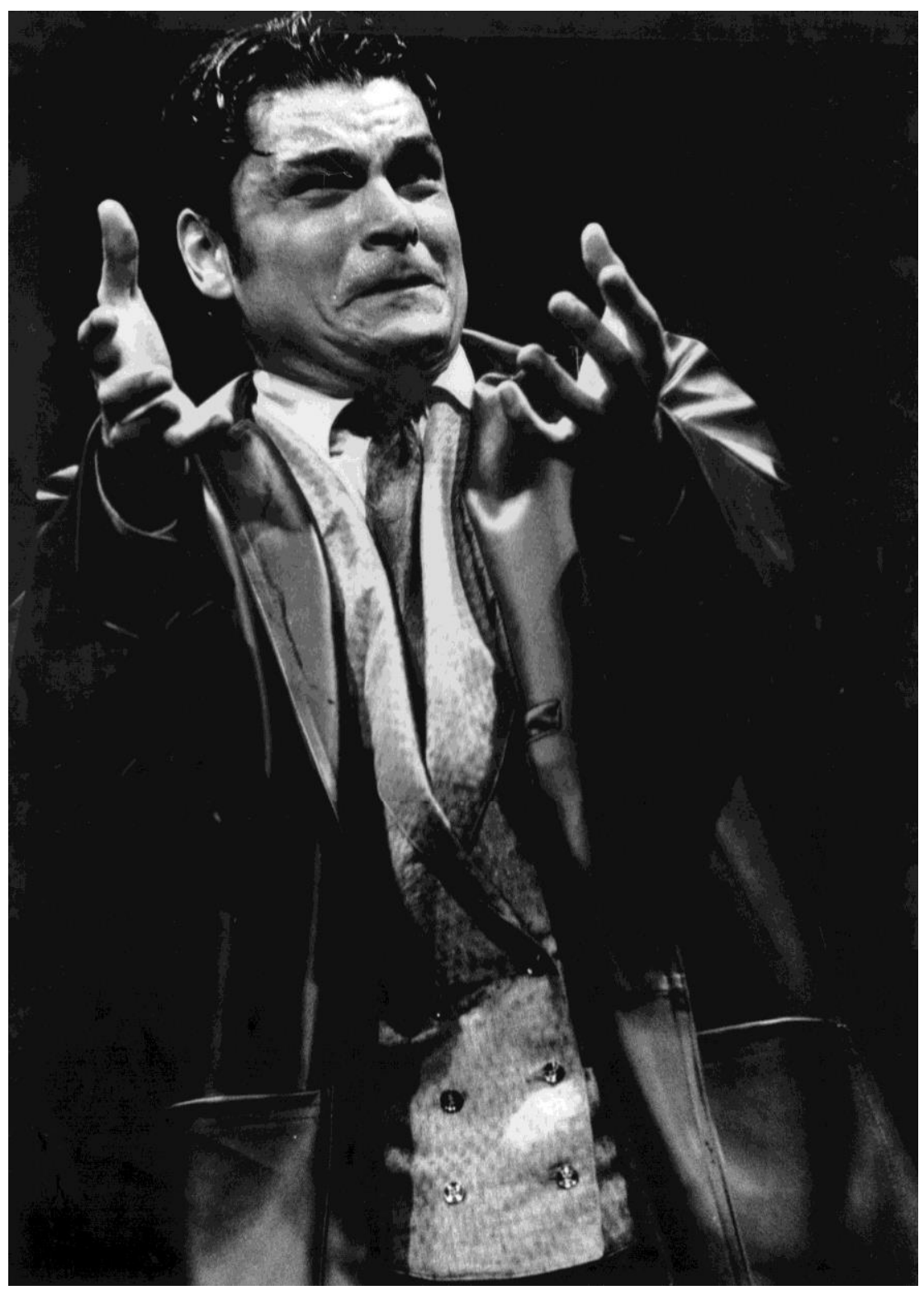

Gustavo Bayer como Bocarra em Santa Joana dos Matadouros, 1998. Foto: João Maria.

Já para Edgar Castro, que representou Slift, o assessor de Bocarra, a régua interpretativa foi outra:

Slift tinha uma desmedida, ao contrário de Bocarra que era ambíguo. Para mim as duas cenas importantes dele eram a descida para mostrar a Joana como os pobres são ruins, em que aparece a Senhora Luckernidle, e a cena na qual ele faz o pregão. São desmedidas! Mesmo ele não sendo o proprietário da fábrica e das ações da Bolsa, ele acredita naquilo. A construção do Slift foi toda calcada em atitudes não refletidas, o que me parece ser típico de todo capitalista selvagem, pois mesmo ele não sendo o dono, esse assessor assumia o papel dos seus patrões partindo para uma selvageria ainda maior (informação pessoal) ${ }^{24}$.

\footnotetext{
${ }^{24}$ Edgar Castro, em depoimento a Ney Piacentini, em 23 maio 2014.
} 
Os dois quadros lembrados por Edgar são: um sobre a Senhora Luckernidle, que trataremos a seguir, e o segundo (citado na p. 33) que versava sobre uma jogada na Bolsa de Valores. Slift ia às turras aumentando o valor das ações atingindo um gozo feérico arrasando com os concorrentes. Por sua vez, Maria Tendlau, a intérprete de Luckernidle, imprimia um toque de tipificação nessa personagem, o que não reduzia sua verossimilhança, pois era ela quem sofria as piores consequências dos atos dos exploradores. Vamos acompanhar sua participação em uma das cenas mais emblemáticas da peça: “A maldade dos pobres”, não sem antes contar como era tal passagem: Bocarra manda Slift levar Joana para ver os pobres e exibi-los na sua ruindade e animalidade, como eram traidores e covardes e que eles mesmos eram os culpados por isso. Slift leva então a missionária aos abatedouros onde um homem caiu nas caldeiras: “Agora ele é um toicinho perdido no mundo" (BRECHT, 1996, p. 26), sentenciava um trabalhador da fábrica. A Senhora Luckernidle batia à porta da empresa procurando por seu marido ausente, alegando que ela estava ali havia quatro dias esperando por ele. Slift propõe à velha que pare de procurar o esposo e almoce de graça na cantina da fábrica por três semanas. Joana acredita que a Senhora Luckernidle não vai aceitar a comida. Slift oferece ainda ao trabalhador que ficou com o paletó do desaparecido (o Senhor Luckernidle) um dólar e um prato de comida para ele contar à Senhora Luckernidle que o marido dela caiu nas caldeiras.

Quando esse homem, diante da mulher do colega morto, deixa escapar que seu paletó é de um homem que foi moído pelas máquinas, a Senhora Luckernidle passa mal, mas em seguida aceita a oferta de almoçar de graça na cantina, pois sua fome fala mais alto. Então Slift pergunta: "Você viu, Joana, como a maldade dela é infinita?" (BRECHT, 1996, p. 30).

Na opinião de Tendlau:

A colher chegava primeiro porque eu estava com fome, a personagem se apresentava pela colher e não por ela mesma. Eu imaginava que a colher entraria em cena antes. O objeto era o impulso da fome, da necessidade e eu pensava que aquilo era um gestus puro, porque ele está traduzindo uma situação social numa coisa muito simples que é essa colher (informação pessoal) $)^{25}$.

Os gestus, ao qual se refere a atriz, podem ser vistos como "As atitudes que as personagens tomam umas com as outras e que constituem o que denominamos domínio

\footnotetext{
${ }^{25}$ Maria Tendlau, em depoimento a Ney Piacentini, em 12 mar. 2014.
} 
gestual. As atitudes corporais, entonações, jogos fisionômicos são determinados por um gestus social: as personagens se xingam, se cumprimentam, trocam conselhos, etc." (BRECHT, 1978, p. 125) ou também: “Os gestus se compõem de um simples movimento de uma pessoa diante da outra, de uma forma social ou corporativamente particular de se comportar” (PAVIS, 1999, p. 187). Porém, menos do que teorizar, ressalto que Tendlau priorizou um problema causado pela fome da personagem. Foi disso que surgiu a relação com a colher e que se revelou em uma veracidade cênica convincente.

Como revisitamos os papéis centrais da obra, voltemo-nos aos menores, nos quais Georgette Fadel corrobora com o nosso aprendizado:

Nas narrativas do espetáculo, eu fazia uma amiga de Joana, a Marta. E procurei por algo desnecessário. Queria criar uma partitura ao narrar, uma marca, talvez até por vaidade, mas não precisava, era tudo mais simples. Bastava narrar com clareza e objetividade o texto que seria melhor do que ficar me questionando o que acrescentar para que aquilo fosse mais teatral. Não precisava elucubrar demais, era preciso abrir mão de coisas excessivas e, no Latão, eu aprendi isso (informação pessoal) ${ }^{26}$.

Chegamos a treinar, em exercícios, como realizar narrativas com objetividade e simplicidade. Geralmente, quando íamos narrar, dramatizávamos os textos e a ideia não era comunicar intensamente, mas chegarmos ao afastamento para termos duas vias em fluxo: as narrativas e os diálogos. Sendo assim, ao incorporarmos personagens, não nos abstínhamos de seus contornos dramáticos (sem exageros, naturalmente), sendo que a nossa narratividade primava pela intelecção. E do despojamento como atriz, minha ex-parceira discute a feitura da peça:

Foi um processo bem conduzido, pois os diretores pediam improvisações com enunciados concretos, solicitando situações claras para os atores. Depois ficávamos quebrando a cabeça, mas isto buscando algo que tinha ficado nítido para nós. Desta forma nós devolvíamos um material para a direção que eles se deleitavam e, no dia seguinte, eles nos devolviam aquilo reelaborado, então eu senti um trajeto íntegro. Foi um processo gordo, de informações, de estudo, com substância e uma condução clara (informação pessoal) ${ }^{27}$.

\footnotetext{
${ }^{26}$ Georgette Fadel, em depoimento a Ney Piacentini, em 02 jun. 2014.

${ }^{27}$ Georgette Fadel, em depoimento a Ney Piacentini, em 02 jun. 2014.
} 
Fadel resume como operávamos em nossos projetos. Todo o elenco contribuía por meio da preparação de fragmentos com a encenação e a dramaturgia, o que resultava na maior apropriação possível dos elencos dos meios de produção na manufatura dos espetáculos.

Por fim, eu fiz alguns pequenos personagens em Santa Joana, que se revelaram um aprendizado. Do industrial Lennox a um informante de Bocarra, passando por um missionário coligado à Joana e a participação nos coros na peça, sem esquecer que cantava e tocava instrumentos de percussão. O que não me passou despercebido em 1998 foi a persistência da direção em não deixar ninguém do elenco menos envolvido com o trabalho e lembro de eu ter sido monitorado em detalhes, mesmo em minhas breves intervenções. Como exemplo, recordo que o meu informante fazia apenas uma entrada e eu estava puxando essa inserção com uma voz que lembrava a de um desenho animado. Fui corrigido para que retirasse aquela caracterização e mantivesse a minha voz normal a fim de não destoar de todo o elenco. E, como nas peças da Companhia geralmente não usamos as coxias, com o grupo sentado em bancos (no caso de Santa Joana) ou no chão (como em outras peças) dos palcos, produzindo sons ou cantando e prontos para entrar em cena, estávamos sempre alertas ao que estava acontecendo no espaço cênico propriamente dito, independentemente da extensão dos nossos papéis, criando de fato um senso de coletividade.

Uma última observação sobre a nossa montagem dessa obra-prima de Brecht diz respeito ao seu alcance, segundo o testemunho de Sérgio de Carvalho:

Por outro lado, mesmo sem o horizonte do socialismo real, esse trabalho exigiu de nós um diálogo com os movimentos sociais brasileiros da atualidade interessados na crítica anticapitalista. Foi uma montagem que nos conduziu para fora do mercado das artes e mudou nossa atitude em relação ao teatro. Deixamos de dialogar apenas com os ambientes culturais intelectualizados (CARVALHO, 2009, p. 20).

Nosso dramaturgo e diretor estava se referindo principalmente ao Movimento dos Trabalhadores Sem Terra (MST), para quem fizemos diversas apresentações (talvez as melhores) de Santa Joana dos Matadouros.

O nome do sujeito (1998)

Cumprida a etapa necessária de criar e treinar um ensemble por meio da produção de espetáculos a partir de textos da família do teatro épico, o desafio seguinte - e a prova dos 
nove - seria olhar para o Brasil e traduzir as observações em texto e espetáculo. Esta seria em esquema rápido a pré-história de $O$ nome do sujeito (COSTA, 1999, p. 9).

Como aponta Iná Camargo Costa no prefácio à primeira edição em livro da peça, nela nos voltamos para os problemas brasileiros, sendo que esta foi a primeira dramaturgia do grupo totalmente composta na sala de ensaios. Durou cerca de dois anos o processo que nos conduziu a essa escrita própria, resultado da simbiose entre os atores e os diretores/dramaturgos ${ }^{28}$. No Recife do século XIX, acompanhávamos os mandos e desmandos de um barão pernambucano que, por sinal, não aparecia em cena, mas sim os personagens que o rodeavam. Algumas tristes figuras, de acordo com o subtítulo da peça: Fragmento histórico e sentimental.

O trabalho começou com a leitura de Fausto na versão do dramaturgo inglês Christopher Marlowe, que foi escrita cerca de duzentos anos antes da reescrita de Johann Wolfgang von Goethe. Após uma primeira e incipiente leitura do texto, a direção nos surpreendeu com uma proposta para que improvisássemos de chofre toda a peça, mesmo que de maneira imprecisa e entrecortada. Um tanto inseguros, fomos ao exercício, que por vezes dava grandes saltos na sequência da história, o que fazia com que algum ator usasse do expediente narrativo "porém antes disto aconteceu que...", sugerindo aos demais que tentassem incluir trechos esquecidos da fábula na improvisação, recheada de soluções cênicas inusitadas, ilustrativas de uma condução coletiva e caótica. Não faltaram lances cômicos como alguém contando um episódio e outrem propondo imagens corporais sem nenhuma correspondência com o que estava sendo falado. Ao final da experiência, nem tudo foi fracasso, pois o conjunto dos atores teve que fazer as escolhas que lhes vieram à lembrança durante o jogo, elegendo intuitivamente certos episódios de Fausto e, naturalmente, descartando boa parte deles. Da tentativa cheia de erros ficaram alguns momentos potenciais, caso fôssemos encenar a obra de Marlowe. Com o passar dos dias, esses primeiros contatos, assim como as posteriores experiências com a versão de J. W. von Goethe para a mesma peça, serviram como uma aproximação ao universo que estávamos abordando, embora ele tenha sido substancialmente transformado ao longo da empresa que derivou em $O$ nome do sujeito.

\footnotetext{
${ }^{28}$ Elenco: Edgar Castro, Georgette Fadel, Gustavo Bayer, Maria Tendlau, Ney Piacentini e Otávio Martins. Na remontagem de 2007 participou o ator Luís Mármora; direção musical: Lincoln Antonio; cenografia e figurinos: Márcio Medina; iluminação: Paulo Heise e Wagner Pinto; cenotecnia: Francisco Bruno; preparação vocal: Sandra Ximenez; colaboração teórica: Uta Atzpodien; texto: Sérgio de Carvalho e Márcio Marciano, com a colaboração de: Ney Piacentini, Maria Tendlau, Georgette Fadel, Otávio Martins, Edgar Castro e Gustavo Bayer; direção: Sérgio de Carvalho e Márcio Marciano.
} 
Entre os motivos que causaram uma guinada no processo que nos remeteu ao Brasil, esteve uma pergunta feita durante os ensaios - qual a relação de Fausto conosco? -, além de uma viagem que a companhia havia feito para a capital pernambucana como convidada do $1^{\circ}$ Festival Recife do Teatro Nacional em 1997. Essa breve estada no Nordeste para apresentar Ensaio para Danton e Ensaio sobre o latão também proporcionou uma maior proximidade com a obra de Gilberto Freyre, fazendo com que nos debruçássemos sobre seus livros Casa Grande e Senzala, Sobrados e Mucambos, Assombrações do Recife Velho, Açúcar e Guia Prático, Histórico e Sentimental da Cidade do Recife. Na esteira desse sociólogo, vieram outros pensadores nacionais como Sérgio Buarque de Holanda e Evaldo Cabral de Melo, que nos auxiliaram na compreensão de aspectos sobre a formação do sujeito brasileiro, com suas possíveis transposições para os palcos. Com isto, o grupo assumiu uma linha de pesquisa que iria fazer parte essencial da nossa trajetória, que foi a produção de dramaturgia autônoma, voltando-se para os temas e problemas do nosso país, sem abandonar as demais influências.

Tendo como referência livros com textos e imagens do Brasil imperial e descrições de estrangeiros que visitaram aquela região durante o segundo reinado, como a crônica $U m$ Barão Perseguido pelo Diabo, de Gilberto Freyre, e o relato de viagem Diário íntimo do Engenheiro Vauthier, os ensaios aconteciam com a permuta de proposição de cenas entre a direção e o elenco, com o empréstimo mútuo na equipe dos materiais de pesquisa (publicações, pinturas, objetos etc.) e um intenso trabalho musical sob a coordenação do maestro Lincoln Antonio, que nos trouxe uma farta coleta de música brasileira de raiz. A confluência de todos esses dados proporcionou um ambiente inquietante, criativo e participativo. Pelo fato de $O$ nome do sujeito ter sido uma obra cuja boa parte da dramaturgia foi construída nos ensaios, houve uma acentuada participação dos atores nessa tarefa, conosco praticando o que ficou conhecido como processo colaborativo ${ }^{29}$. Foi nele que ficou mais clara, para nós atores, a transmissão pelos diretores/dramaturgos do grupo de como elaborar uma cena teatral evitando erros recorrentes.

Em uma dinâmica em que o elenco preparava, geralmente em duplas, células a serem improvisadas para que os demais integrantes as assistissem, havia uma orientação de não gastarmos muito tempo com as introduções, mas entrar no problema da cena o mais diretamente, de modo a evitar clichês como os personagens se apresentando uns aos outros ou a emissão de textos pela boca dos personagens que localizassem a época e a cidade. E isso se

\footnotetext{
${ }^{29}$ Procedimento no qual os atores contribuem para o estabelecimento da dramaturgia e da encenação, propondo e improvisando cenas, textos e outros componentes de uma obra teatral, em consonância com a dramaturgia e a direção.
} 
traduzia em: "A - Olá como vai? B - Tudo bem e o senhor? A - Tudo bem também..." ou então: “A - Vim do interior para o ver o Imperador Dom Pedro II em visita à nossa capital. B - Eu, que não tenho posses, terei que me contentar em vê-lo de longe, atrás das cordas que separam os ricos dos pobres". Outra recomendação era a de que as improvisações contivessem uma mudança em sua rota, o que significava alguma ocorrência que causasse alterações nos fatos e/ou nos personagens da situação.

Uma terceira preocupação foi a de como escapar dos modos de representação facilmente identificáveis, os quais percebemos naquela altura como predominantes. Em um quadro que envolvia escravos, nós praticamente imitávamos os atores da televisão brasileira e seus clichês como o branco malvado e perverso, raivoso e gritando, e os negros como vítimas com vozes graves arrastadas e até o vocabulário usado era o de "sinhá, sinhô etc.". Na medida em que fomos nos dando conta de que estávamos reproduzindo o que esse massivo meio de comunicação impôs a quase toda a sociedade brasileira, fomos encontrando outras formas de interpretar personagens da história do Brasil, sem necessariamente termos que copiar sotaques e posturas corporais óbvios. O que fizemos foi procurar um modo simples de atuar junto às personas como os empregados de um barão, um padre, brancos sem posses, ex-escravas e exescravos. Por se tratar de um ambiente com figuras reconhecíveis, buscávamos antes fazê-las como quem os narra e não imitando o pseudonaturalismo televisivo. Partindo de uma quase neutralidade, sem imprimir vozes e trejeitos corporais tipificados, aos poucos os personagens iam adquirindo características próprias, a ponto de, depois de um tempo de ensaios, reintroduzirmos algum traço mais acentuado em um ou outro papel. Foi como se tivéssemos que primeiro promover uma limpeza nas formas comuns de representar personagens regionais do passado brasileiro para depois retomá-los sem maneirismos.

Em meio às experimentações, os atores puderam ainda expor suas próprias descobertas, trazendo ideias e proposições de acordo com suas investigações fora da sala. Assim, foi-nos possível propor rascunhos das personagens próximas ao Barão de diversas formas: através de canções, pequenas narrativas, cenas dialogadas ou ainda uma mistura delas. "Durante os ensaios levávamos um notebook para o palco e registrávamos os improvisos do elenco, conferindo-lhes, depois, uma forma literária" (CARVALHO, 1998, p. $5,13)$.

A afirmação de Sérgio de Carvalho atesta que o elenco e a dramaturgia caminhavam lado a lado. $\mathrm{O}$ meu personagem, por exemplo, teve a seguinte evolução: seus primeiros traços noticiavam sobre um tipo que havia sido funcionário de um cemitério, porteiro do Teatro Santa Isabel do Recife Antigo e animador de velórios com o uso de uma grande novidade da 
época - o gramofone, entre outras curiosas funções. Com o avanço dos ensaios, Lyra (nome com o qual foi batizado o meu papel) passou a ser um vendedor de mercadorias nos engenhos da região. Por sua vez, o historiador Evaldo Cabral de Melo contou aos nossos dramaturgos que os mascates daquele período em Pernambuco eram portugueses e Lyra finalmente se tornou um empregado do seu tio (um comerciante português). Assim, ao longo da peça, meu papel foi de um recém-chegado ao país, abrasileirando-se e assumindo um caráter melífluo que se adaptava aos costumes locais com negativas consequências éticas e sociais. Minha figura no espetáculo terminava por se constituir em um espelho da formação do sujeito brasileiro, cuja personalidade suscetível se deixa moldar pelo difuso contexto histórico nacional.

Entre nós, da Companhia do Latão, é aconselhável que os atores não se apossem das suas criações nos ensaios, pois um improviso proposto por uma atriz ou ator, por melhor que tenha sido, pode ou não ser aproveitado no resultado final, acontecendo às vezes que a ideia de um passe a ser conduzida por outros e também o contrário. Entretanto, é preciso esclarecer que na realidade não existe desperdício e, mesmo o que não venha a ser utilizado em um determinado projeto vale, no mínimo, como treino imaginário, como investigação artística ou como material para ser retomado em outros processos do grupo, em um contínuo levantar de propostas cênicas. E em $O$ nome do sujeito ocorreu uma quebra de expectativas dos atores em relação aos protagonismos. Mesmo sendo uma antiga cultura teatral, que envolve quem vai fazer o personagem principal e quem será coadjuvante, indiretamente isso estava em pauta neste e em outros trabalhos da companhia. Todavia, por uma bem sacada resolução dramatúrgica, o personagem central da obra, o Barão que a tudo dominava, ficou oculto, não aparecendo em cena diretamente, mas sempre presente através dos demais papéis que o rodeavam.

Para personificá-los, seguimos o realismo atento aos detalhes, que já estava em curso em trabalhos anteriores, traduzindo a busca pela veracidade de cada gesto dos personagens. Edgar Castro, ator condutor de Wagner - o preposto do Barão -, teve que dar conta da ignorância de sua figura como quando ele vibrava por estar presente em um jantar oferecido pelo seu patrão ao Imperador Dom Pedro II. No banquete, comemorado no palco do Teatro Santa Izabel, Wagner, na companhia do Padre (Otávio Martins), ocupava um canto da grande mesa e se deslumbrava com as mínimas atitudes de seu superior junto ao Imperador. O gesto de limpar a colher na toalha da mesa para comer a sobremesa e, depois de engoli-la, cuspir o caroço (imaginário) da ameixa na mesma colher para em seguida jogá-lo ao chão e chutá-lo 
para debaixo da mesa, deu a seu papel, entre outras ações, a devida postura de alguém que quer ser da classe superior, mas se trai em hábitos miúdos.

Georgette Fadel, entre outros personagens, conduzia uma escrava presa em focinheira e que comia terra. Isso não era feito realmente, e sim com ela apenas raspando o chão do palco. Era preciso uma realização simples, como quem a descreve, uma vez que a imagem já era forte o suficiente e qualquer deslize levaria a cena, que já era grotesca, para algo pior e isso poderia retirar sua força intrínseca. Ver a terra à sua frente, pensar no seu gosto na boca e se isso saciaria sua fome, traduzia-se em um ato de se violentar porque se está sendo violentado e isso era mais importante do que demonstrar quão repulsivo seria ter que engolir terra.

Gustavo Bayer cuidou de duas criaturas: um ex-escravo tornado um mendigo bêbado e uma senhora cega - Dona Branca -, adoradora de uma imagem do Menino Jesus. Bayer é um ator cuja presença cênica é forte e dono de uma potente voz. Para dar vida às suas figuras, seu trabalho foi o de diminuir a sua natural densidade teatral. Se apostasse em reforçar seu grave tom vocal e seu característico gestual físico, seus personagens se assemelhariam a ele mesmo. Ao contrário, Bayer partiu para um vinco pormenorizado de fazer os seus papéis, o que lhes conferiu leveza e estranhamento no caso da velha cega e ojeriza e comiseração ao mendigo. Para vivenciar os contrastes, Gustavo investiu no que seriam atitudes próprias dos personagens com suas obsessões, o que não é tão fácil, uma vez que, para dar vida a pessoas à margem do que se tem como normal, é preciso lucidez em cena e ponderabilidade nas ações. Assim, quando sua velha sentia sensorialmente com as mãos que seu menino Jesus de porcelana tinha um pequeno pênis (o ator manipulava um objeto imaginário que o público não via, dentro de uma caixinha de madeira real), não era suficiente registrar somente em palavras - "E tem também uma piroquinha! Eu não me conformo com a piroquinha do meu menino!" (CARVALHO; MARCIANO, 2008, p. 45), mas sim imaginar em detalhes o diminuto falo no corpo de sua imagem religiosa fictícia, enquanto emitia o texto relativo à cena. Como ator, penso ser melhor buscar o que não temos para que possamos relacionar àquilo que já possuímos. A mescla de dons inatos com o que é preciso descobrir fora de nós mesmos pode ampliar o nosso repertório, retirando-nos do já conhecido, a meu ver não recomendável à prática da atuação.

Maria Tendlau personificou Margarida, a jovem pobre pretendida pelo Barão e num extrato essa moça tinha que matar uma galinha a pedido de sua tia (a senhora cega de Bayer). O episódio era feito em um quintal apenas sugerido e sem o animal no palco. A atriz criava o espaço e a galinha, inicialmente perseguindo-a, em seguida a capturando com as mãos e 
finalmente torcendo o seu pescoço para que ela morresse. Maria não era uma atriz com técnicas de mímica, mas ao materializar visualmente o quintal da casa em que viviam Margarida e a tia e ao perseguir a galinha com a convicção de que ali havia um bicho vivo e inquieto que fugia agilmente, o agarrando com as mãos, porém com medo de que o animal reagisse, a cena ganhava em veracidade. Ao relutar em matar a galinha, pois era a primeira vez que ela cometia esse ato, e ainda pressionada pela tia para que torcesse o pescoço da presa, não havia entre os atores e no público quem não acreditasse que de fato estava acontecendo aquela luta entre a jovem brejeira e a galinha. Mais do que a destreza física e corporal, a atriz fazia uso da visualização do quintal e do animal, a ponto de reproduzir em seu corpo os espasmos do bicho prestes a morrer, torcendo com repugnância o seu pescoço.

Otávio Martins teve a incumbência de personificar um Padre nessa obra, personagem presente em diversos enredos que tratam de episódios da história do Brasil. O de Otávio se manifestava na peça como um religioso preocupado com a emancipação social de sua comunidade, com a exclusão dos negros e dos pobres e desconfiava do alcance dos benefícios que a presença do Imperador e de estrangeiros poderia trazer ao país e à Região Nordeste. Mas era em uma visita espiritual a uma escrava presa (Georgette Fadel) que ele exibia sua dualidade quando, ao final de um discurso de conforto à negra, pedia-lhe, não sem alguma sensualidade, um beijo. $\mathrm{O}$ ator executava essa face de seu papel de forma neutra, com frases que levavam alguma esperança à escrava encarcerada. Porém, ao pedir-lhe um beijo, aumentava a opressão sobre a negra já oprimida pela sua condição e pela situação de presa em que ela se encontrava. O desejo do Padre já estava presente desde o início da cena, como se as palavras de solidariedade fossem uma máscara que segurasse sua intenção sobre a escrava. A passagem exigia que o ator levasse em conta duas dimensões: a externa - do mensageiro de que aquela situação humilhante poderia ser superada; e a interna - de uma energia sexual que borrava a solidariedade.

Não obstante, de par com a carga dramática e realista da nossa interpretação, tínhamos a instância narrativa entre as cenas e por dentro delas. Não apenas se narrava legendando um quadro ou acontecimento, como os próprios personagens falavam de si mesmos em terceira pessoa. E, por exercê-los, criamos alguma habilidade niso:

Era como se a capacidade de criar experimentos de narrativa fosse se amalgamando a ponto de imediatamente assimilarmos qualquer evento. Já pensávamos assim coletivamente, havia esse código como princípio básico para improvisar. E as cenas vinham aos borbotões. A continuidade desses experimentos, ao longo desses anos juntos, nos treinou. Claro que, individualmente, esse código trouxe outras consequências como a preocupação de estarmos 
nos acostumando a um formato e criar mecanismos para não cristalizar os processos de pesquisa, as improvisações, as cenas, o espetáculo e o grupo em si. Acho que por isso o processo de $O$ nome do sujeito foi tão importante: além da preocupação intelectual sobre o que fazíamos, sabíamos da importância em procurar algo novo. A quantidade de cenas improvisadas foi gigantesca, suficiente para montar dois espetáculos e o corte dramatúrgico foi feito seguindo o preceito da construção da cena épica: um jantar entre barões, uma escrava que se joga ao mar, o estupro da virgem, a subserviência - tudo isso criado a partir de poucos elementos de cena, ambientados numa pesquisa musical a partir de cantos dos escravos no século XIX (informação pessoal) ${ }^{30}$.

O resumo de Martins aglutina a abundância de materiais ofertados pelos atores aos dramaturgos-diretores que, ao nos instigarem a trabalharmos em mais de uma frente - atuar, propor breves dramaturgias e encenações e criar canções -, tinham como devolutiva uma fartura cênica aproveitável ou descartável. Quanto à atuação propriamente dita, a contradição entre os aspectos externos (o que se passa por fora, nos gestos do corpo de um papel - sua dimensão objetiva) e internos (o que acontece dentro do papel, em sua psique - a sua dimensão subjetiva) dos personagens foi apontada de forma embrionária em $O$ nome do sujeito, como no caso do Padre de Otávio Martins, muito embora viesse a se tornar um dos destaques em nossas investidas sobre a interpretação, como veremos ao longo deste escrito.

Sobre o meu envolvimento com Lyra, o português recém-chegado ao Brasil pelas mãos de um tio que o explorava em sua loja de secos e molhados, relato algumas passagens dos ensaios. A partir do indicativo repassado pela direção aos atores, para que fizéssemos mudanças de sentidos dentro dos fragmentos em experimentação, resgato um improviso entre mim (como Lyra) e Gustavo Bayer (como o mendigo bêbado). Meu português, indo do trabalho para casa, ao ver aquele coitado esmolando na rua, meio dormindo, meio fora de si, a princípio o rejeitaria pelo asco que lhe causava aquele ser repulsivo. Porém, durante o improviso, eu via uma moeda no chão que algum passante teria jogado ao mendigo. Lyra passava por dificuldades: seu tio lhe cobrava a passagem de navio de Portugal para o Brasil e, por mais que trabalhasse para o seu parente, a sua dívida só aumentava, pois este lhe reclamava os juros da viagem. Percebendo que era possível pegar para si a moeda sem que o mendigo reparasse e, dividido entre os seus problemas e a sórdida decisão de roubar um pior que ele, decidia recolher o metal para si. No exato momento em que estava colocando a moeda no bolso, o mendigo reagia e Lyra achava que tinha sido visto roubando a esmola. Mas

\footnotetext{
${ }^{30}$ Otávio Martins, em depoimento a Ney Piacentini, em 11 mar. 2016.
} 
não, o pobre diabo apenas resmungara e então o lusitano resolvia levantá-lo do chão e dar-lhe uma ajuda (a mesma que ele havia suprimido ao bêbado). Ao fim, a cena ficou com duas viradas: da recusa inicial em se relacionar com o mendigo Lyra passava a furtar a sua miséria para em seguida ajudá-lo com o saldo do roubo. Os fins, durante a cena, mudaram conforme a relação entre os personagens. Se apenas seguíssemos um roteiro preestabelecido no jogo, não teríamos encontrado os desvios que os personagens vivenciaram na improvisação. Foi nessa passagem que se iniciaram as mudanças no personagem Lyra, que dali para a frente gradativamente abandonaria sua postura de humilhado pelo tio para se tornar, pouco a pouco, um arrivista, um sujeito que, ao aderir ao costume da troca de favores vigentes no Brasil, sobe na vida.

Nesses episódios envolvendo dinheiro, eu enxergo o começo de uma minha atitude dialética no arriscar-se das cenas, além de um incipiente aprendizado dramatúrgico. Ou ainda a absorção da matéria negativa a que se referia Brecht ${ }^{31}$. Aproximemo-nos: ao ouvirmos dos nossos coordenadores (dramaturgos/diretores) que toda cena deveria conter um câmbio, ao nos dirigirmos às improvisações, minimamente combinávamos em que altura a cena poderia sofrer uma reversão. Mas devíamos estar abertos ao inesperado, sem a obrigação de seguirmos um esquema traçado previamente. Ou seja, eu e Bayer havíamos conversado sobre como Lyra e o mendigo se conheceriam e se algo de diferente acontecesse durante o exercício, adaptaríamo-nos um ao outro. Foi quando, em cena, vendo que ele estava gemendo de tão bêbado e quase dormindo, que, num átimo, veio-me a ideia de lhe furtar a moeda que ficara no chão próximo ao seu corpo. Assim, entre um esboço previamente pensado que poderia conter uma virada e a intuição, o meu pobre Lyra surrupiava um pior que ele. Sintetizando: tivemos a iniciação à dialética improvisacional pela abordagem oposta à de um ser humano ajudar o outro; o explorado empregado português roubava o pedinte à espera de caridade, porém deixando ao espectador a rejeição ou não do gestus do personagem. E se levarmos em conta que esse português devolvia a moeda ao indigente sem que ele percebesse o furto, crescia a ambivalência entre a dupla. Conduta similar vivanciamos em outro episódio, no momento em que Lyra, socorrendo em seus braços o mendigo atropelado pelo Barão a cavalo, ao ter em mãos uma taleiga de dinheiro atirada por Wagner para comprar seu silêncio,

\footnotetext{
31 “"...] com o lixo da sociedade, com comportamentos grotescamente criticáveis, com exposição pelo avesso, com a capacidade de ver o melhor no pior, só o aprofundamento da sondagem negativa pode gerar uma perspectiva contemporânea" (CARVALHO, Sérgio de [org.]. Questões sobre a atualidade de Brecht, em Introdução ao Teatro Dialético. São Paulo: Expressão Popular, 2009, p. 46-47).
} 
depois de alguns segundos atônito, esse aprendiz de caráter moldável opta por aceitar a oferta e calar sobre a responsabilidade do Barão no acidente.

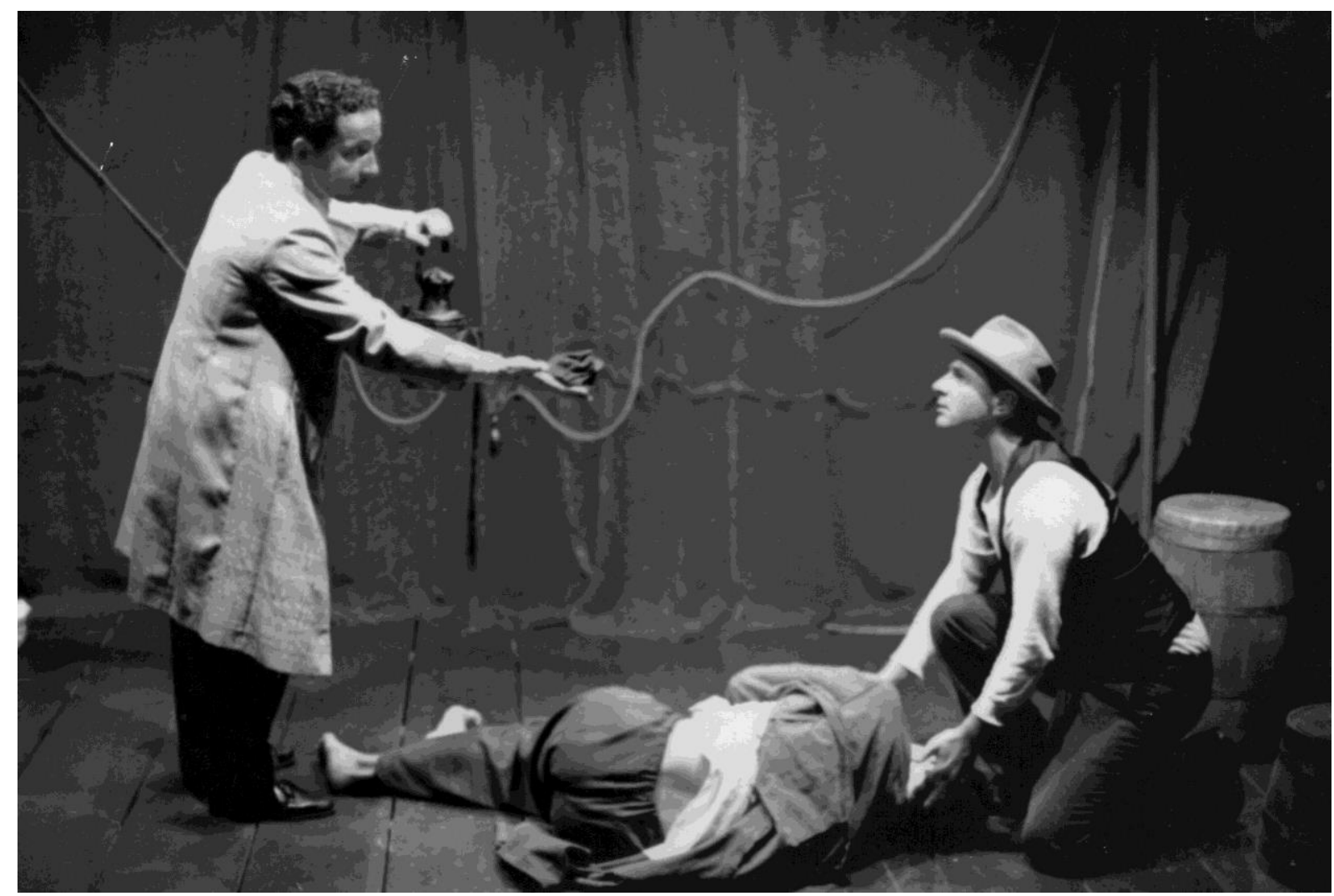

Edgar Castro (Wagner), Gustavo Bayer (mendigo) e Ney Piacentini (Lyra). O nome do sujeito, 1998. Foto:João Maria.

Ainda em relação a esse personagem, foi com ele que voltei a recorrer a algumas práticas conhecidas para intensificar os contornos de um papel. Adotei um caderno de anotações no qual não só escrevia as cenas que viriam a ser testadas em improvisos, mas pedaços da biografia de Lyra, ora extraídos de dados pesquisados, ora inventados. Trechos de textos históricos ou sociológicos que pudessem envergar o personagem também foram transpostos para essas folhas e ainda recortes de imagens correlacionadas. Descrevo alguns trechos do que lá registrei:

16.09.1998 - Roubo/chantagem/extorsão. Um fiscal da prefeitura anda fazendo benfeitorias em sua propriedade. Lyra fica intrigado com o fato. Vai até a repartição onde ele trabalha e suborna um outro funcionário para saber qual é o salário do fiscal. Consegue a informação de que não é lá grande coisa o que ganha o tal. Começa a persegui-lo em suas andanças. Descobre que ele é quem cobra a taxa de iluminação a gás das ruas com lampiões e que alguns destes, em certas ruas, são desligados mais tarde que o normal. Ao invés das $22 \mathrm{~h}$, só lá pela meia-noite. Continua a bisbilhotar e descobre que quem paga uma taxa por fora tem 
os lampiões na frente de suas casas apagados mais tarde. Lyra planeja chantagear o fiscal corrupto.

Sem data - Perpetrar uma situação em que os haveres particulares se confundam com as posses da Administração, e esta continue a se realizar por via de expedientes, favores, privilégios e conflitos pessoais (FRANCO, 1969, p. 140).

Sem data - CARNEIRO (tio de Lyra) Já te forneci mais de uma dezena de endereços, já te disse quem gosta do quê, como trabalhar com créditos e não me apresentas os dividendos!

LYRA: Mas, patrício, a maré não está para peixe.

CARNEIRO: Isto é para quem não gosta de trabalhar, tens uma dívida. Esquecestes quem pagou o vapor para chegares até aqui. Estás neste país de favor!

LYRA: Eu já tentei de tudo!

CARNEIRO: Não tentaste! Estás amolecido pela permissividade, pelo calor. Estás com alguma rapariga?

LYRA: Não!

CARNEIRO: Mas então, vamos, me mostre como trabalhastes (informação pessoal) ${ }^{32}$.

O primeiro trecho é uma descrição imaginária que fiz de Lyra perseguindo um fiscal, o segundo uma anotação do livro Homens livres na ordem escravocrata e o terceiro um diálogo que escrevi entre ele e seu tio/patrão. São pedaços que, ao lado de outros pontos, serviram para se criar a ambientação do personagem.

Para completar, vejamos o que dizia Sérgio de Carvalho sobre a atuação no grupo naquele estágio:

Nós fazemos um trabalho de ator dentro do grupo que não parece trabalho de ator. Lógico que existem processos tradicionais em nossos ensaios, aquecimentos, exercícios, experimentos etc. e tal. Mas fundamentalmente os atores estão improvisando material dramatúrgico o tempo todo. Nas cenas de acabamento, jamais a gente diz para onde o ator tem que andar, só muito no final, se necessário. Nós nunca trabalhamos, por exemplo, mandando um ator decorar um texto depois ir marcando. Decorar não é importante. Quer dizer, o ator tem que inventar o texto dele e aí no final nós damos uma forma para esse texto. Decorar texto é a última etapa do processo. Trabalhamos a partir de improvisos de atuações. Esse método se liga um pouco ao método das ações físicas de Stanislavski ${ }^{33}$. Se liga porque não é exatamente a mesma coisa. Tentamos adaptar à nossa experiência dentro das nossas linhas. O ator vai ganhando consciência ao longo do processo. Ele nunca tem

\footnotetext{
${ }^{32}$ Material oriundo dos arquivos de Ney Piacentini.

${ }^{33}$ Método das Ações Físicas (ou Análise Ativa): recurso em que os atores tomam conhecimento de uma determinada dramaturgia sem a leitura prévia do texto, mas sim através de improvisações coordenadas pela direção que, gradativamente, fornece as indicações ao elenco até que este se aproprie da obra por meio de suas ações.
} 
que se apropriar de uma forma, ele é sempre gerador da forma. É um trabalho lento e difícil. Às vezes o ator tem a sensação de que ele não está ensaiando, é um processo muito delicado (CARVALHO, 1998, p. 4) . $^{34}$

A propósito, um importante aprendizado pessoal aconteceu durante os estudos para $O$ nome do sujeito. Da leitura de Raízes do Brasil, de Sérgio Buarque de Holanda, retiramos a crítica de uma postura que contamina as relações sociais até os dias de hoje. Ela diz respeito ao tratamento diferenciado que damos a classes sociais distintas. Dependendo da nossa formação, tratamos bem as classes superiores e o inverso em relação às classes baixas. É como se fôssemos subservientes aos ricos e tratássemos mal aos pobres. Depois de constatar que eu reproduzia esse vício comportamental, passei a reparar como lidava com esse problema, observando a distinção das pessoas segundo seu nível social. Reparei que dois personagens da peça, Wagner (o empregado do Barão) e Lyra agiam como que transferindo a opressão que recebiam dos de cima para aqueles que estavam abaixo deles. Com o tempo, fui percebendo esse preconceito social e procurei corrigir essa atitude que absorvemos da nossa educação, sem nos darmos conta. Hoje posso dizer que, se não sou o mais educado dos homens, ao menos tento ser menos desigual no trato dispensado às pessoas, independentemente de suas posses.

O primeiro repertório - Ensaio para Danton: segunda versão (1999)

Quando reunimos nossas quatro primeiras realizações para as apresentarmos ao público, refizemos Ensaio para Danton que, ao lado de Ensaio sobre o latão, Santa Joana dos Matadouros e $O$ nome do sujeito, formaria o primeiro repertório da Companhia. Recapitulemos antes a primeira versão de Danton feita em 1996 para, em seguida, tratarmos das modificações realizadas na segunda montagem de três anos depois:

Sérgio disse que a peça era sobre a falência da Revolução Francesa. Então veio a pergunta: qual é a nossa falência? É a representação. Assim, esta é uma obra sobre uma representação que não dá certo, que está falida. Por isso os elementos teatrais se evidenciam em cena: os figurinos de ensaios, as bambolinas que eram as guilhotinas e a luz de serviço usada como iluminação em alguns momentos. As repetições vieram junto com o ponto de teatro e a peça começava na última cena, com o palco limpo e terminava com um telão de teatro do século XIX. Um teatro pela metade, a meio pau. Também disso veio de se colocar o público para que assistisse à obra no palco, como num ensaio, porque às vezes os ensaios são 
melhores que os espetáculos prontos. E isso espelhava a discussão do texto, pois não eram só recursos formais (informação pessoal) ${ }^{34}$.

Assim como a Revolução Francesa, a peça não se dava por finalizada e se mantinha esboçada. Este e os demais fundamentos esclarecidos por Maria Tendlau permaneceram na segunda versão que, porém, sofreu alterações. Em 1999, houve mais intervenções do grupo sobre os originais de Georg Büchner, o que transformou a encenação: "Modificamos a montagem com o objetivo de diminuir o foco nos conflitos individuais de Danton e buscar uma maior ressonância social" (CARVALHO, 1999, p. 1).

A colocação de Sérgio de Carvalho referia-se a que, na primeira versão de 1996 (quando ainda não tínhamos o nome de Companhia do Latão), a desilusão de Danton era preponderante diante do processo revolucionário. Ou seja, na variante seguinte se relativizou o lirismo de Danton para abrir espaço às pretensões de Robespierre, Camille Desmoulins, Legendre e Saint-Just, assim como para duas novas personagens, Cristininha e Gauché, que foram criadas pela equipe:

A provocação veio da direção. Eles diziam que era preciso que tivéssemos uma visão do povo, fora do contexto dos revolucionários. O ponto de vista popular já existia na personagem pelo ponto de teatro, o bêbado Simão, feito pela Maria Tendlau, mas os dramaturgos consideraram importante inverter essa perspectiva para além do texto de Büchner. Foi improvisando que criamos essas duas figuras. De início acionamos as possibilidades corporais, na base do Heitor Goldflus portô e da Georgette Fadel volante, com ela pequenininha subindo no meu ombro. Especificamente sobre o meu personagem Gauché, eu pensei nele como quem tem um corpo de valentão, mas pronto para fugir a qualquer momento. Em uma briga, por exemplo, ele daria um cascudo em alguém no meio do salão e sairia correndo para depois contar que participou ativamente da luta. Eu experimentava a partir disso. Outro dado eram os olhares. Como ele tinha como marca as mentiras, os exageros, Gauché estava sempre olhando para os lados, porque alguém poderia chegar e o desmentir. Ele era multifocal, atento a vários lados para não ser pego. Nunca olhava nos olhos de sua parceira Cristininha, pois precisava prestar atenção em quem estaria chegando, mesmo que a cena fosse só deles dois. Eram condutas particulares sobre o papel que não necessariamente o público percebia. E na prisão eu tinha a sensação de que ele fora preso de manhã para ser solto à noite. Na contramão de estar abalado, meu papel se comportava como um herói contando falsas proezas para Danton, Camille e os outros presos (informação pessoal) ${ }^{35}$.

\footnotetext{
${ }^{34}$ Maria Tendlau, em depoimento a Ney Piacentini, em 12 mar. 2014.

${ }^{35}$ Heitor Goldflus, em depoimento a Ney Piacentini, em 06 abr. 2016.
} 
O relato de Heitor Goldflus vai do geral ao particular, reportando como surgiram os personagens que não estavam na dramaturgia original e o porquê disso. Os pormenores da íntima relação do ator com o seu papel nos dão a noção de como ele aproveitava seu corpo robusto e enxertava falhas comportamentais em sua criatura.

Como era (e é) comum na Companhia do Latão, retomar uma peça significava não apenas reensaiá-la substituindo um ator por outro e manter a mesma estrutura de antes. Em Ensaio para Danton II aproveitamos para rever inclusive a ótica adotada em 1996, deslocando a melancolia de Danton para condutas mais ativas dos outros papéis. A relação entre Danton e Robespierre, que antes pendia para o primeiro, foi reelaborada fazendo com que as forças se equilibrassem. Enquanto na montagem de 1996 o personagem título ganhara em identificação com a plateia em uma encenação que o colocava como o centro do rumo brutal que a Revolução tomara, na segunda versão sua postura foi problematizada, com Robespierre não sendo tratado apenas como o carrasco irracional daquelas transformações. Na refação da peça em 1999, o radical Robespierre poderia ter tido suas razões políticas para querer enviar seu amigo à guilhotina.

É de se conferir o que escreveu uma crítica carioca (que nem sempre endossou nossos projetos) a respeito da readaptação de Danton:

[...] Dá a perfeita impressão de ser o resultado de uma busca honesta, autêntica, de uma linguagem apta a enfatizar um máximo de politização do texto de Büchner, cuja fragmentação já de si abria a porta para improvisações e "enriquecimentos esclarecedores" (HELIODORA, 1999, p. 3).

Todavia, como atores, tivemos que procurar por mais dados que subsidiassem as possibilidades de alterações na reinvestida sobre a dramaturgia de Büchner. Foi preciso reler e ler livros do período para que eles renovassem o nosso interesse e dos quais pudéssemos extrair ideias de novos quadros para a segunda versão. Como em nossa equipe os estudos sempre são traduzidos em cenas, apresentamos nos ensaios as pesquisas bibliográficas em teatralizações. Da minha parte, quando em Ensaio para Danton II fui escalado para fazer o papel de Robespierre (na primeira montagem eu não estava), como é de costume, fui estudar. Não haveria como fazer uma obra sobre a Revolução Francesa sem conhecê-la para além da criação de Georg Büchner. Entre os livros que li, estavam o de autoria de Jean Matrat: Robespierre - o incorruptível, e logo na primeira contracapa dessa publicação me deparei com: "Homem complexo, influenciado pela filosofia de Rousseau, sua vida é uma teia de 
contradições na luta pelo poder" (MATRAT, 1977). Ao me deparar com essa frase, puxei da estante $O$ contrato social, de Jean-Jacques Rousseau, para entender um pouco mais sobre as possíveis raízes dos pensamentos do meu personagem. E, associando as duas leituras (Rousseau-Matrat), encontrei o que supus, no filósofo do século XVIII, ter persuadido o meu revolucionário:

O povo, por si, quer sempre o bem, mas por si nem sempre o encontra. A vontade geral é sempre certa, mas o julgamento que a orienta nem sempre é esclarecido. É preciso fazê-la ver os objetos tais como são, algumas vezes tais como eles devem parecer-lhe, mostrar o caminho certo que procura. Defendê-la da sedução das vontades particulares, aproximar a seus olhos os lugares e o tempo, pôr em balanço a tentação das vantagens presentes e sensíveis com o perigo dos males distantes e ocultos. Os particulares discernem o bem que rejeitam. O público quer o bem que não discerne. Todos necessitam, igualmente, de guias. A uns é preciso obrigar a conformar a vontade à razão, e a outros, ensinar a conhecer o que quer. Então, das luzes públicas resulta a união do entendimento e da vontade do corpo social, daí o perfeito concurso das partes e, enfim, a maior força do todo. Eis donde nasce a necessidade de um legislador (ROUSSEAU, 1999, p. 108).

Por essa leitura, podemos ter que meu personagem seria o "guia" e o "legislador" que o povo necessitaria entre outros pontos de identificação sobre o ideário rousseano. Daí poderia vir a sua determinação em fazer a história se transformar de fato. E pela biografia de Jean Matrat, através de uma estreita relação com seu texto, eu vertia os discursos contidos no livro em oratória do personagem, deixando a cargo da dramaturgia e da direção a opção de as absorverem ou não: "Peço que este memorável acontecimento seja conservado como um monumento destinado a alimentar no coração dos povos o sentimento dos seus direitos e o horror dos tiranos e na alma dos tiranos o horror salutar da justiça do povo" (MATRAT, 1977, p. 189). A citação se referia à queda do rei Luís XVI e foi um, entre outros, dos excertos que levei experimentalmente aos ensaios na retomada do espetáculo. Entre as cenas em que eu o interpretava, estava a que eu discursava no Clube dos Jacobinos, onde professava sobre o que realmente acreditava, estabelecendo os princípios do papel:

ROBESPIERRE: Eu peço a palavra. Vocês querem a liberdade do indivíduo quando ainda não conquistamos a liberdade pública. Estamos em guerra, é preciso uma atitude extraordinária. Em tempos de paz, basta a virtude; em tempos de guerra devemos fortalecêla com o Terror. O Terror, porque sem ele a virtude seria impotente. A virtude, porque sem ela o Terror seria nefasto. Vocês pedem misericórdia para quem? Para os monarquistas? Para os traidores da Revolução? Nunca. A verdadeira obra de misericórdia é combater os opressores dos homens comuns. Misericórdia sim, mas com o cidadão pacífico. 
Misericórdia com os inocentes, misericórdia com os fracos. Misericórdia com a humanidade (MATRAT, 1977, p. 347).

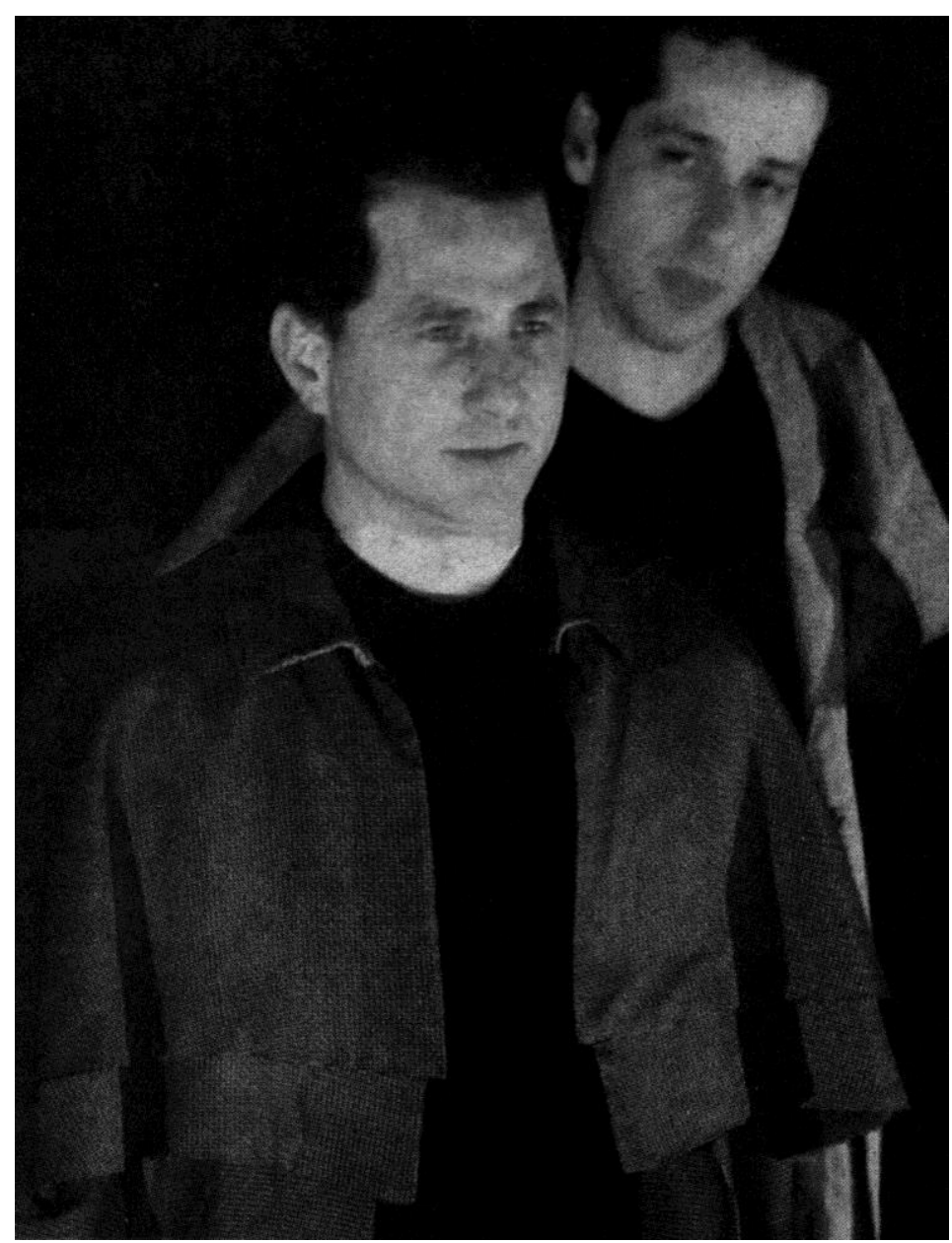

Ney Piacentini (Robespierre) e Otávio Martins (Saint-Just). Ensaio para Danton, 1999. Foto: Sérgio de Carvalho.

À ocasião eu não tinha consciência dos pormenores que tais cenas requeriam. Pergunto-me se deveria ter definido mais exatamente o dia e a hora do discurso no Clube dos Jacobinos e quem claramente eram os presentes na assembleia. Não que eu não tivesse conhecimento sobre a reunião, mas poderia saber bem mais. Esses questionamentos perduram até a atualidade, em menor grau talvez, e só com muita persistência diminuíram a sensação do quanto eu desperdiçava ao abrir mão de ser mais aplicado junto aos meus personagens.

A fim de passarmos à próxima etapa dos projetos do grupo, deixo a opinião de um jornal carioca, que bem definiu, em 1999, quando apresentamos Ensaio para Danton dentro do nosso primeiro repertório no Rio de Janeiro, o propósito em construção da Companhia:

A Cia do Latão traz para a peça uma das suas características, que é a provisoriedade dos espetáculos, isto é, uma montagem que se mostra ao público despreocupada como produto 
artístico acabado, mas como matéria formativa sempre em constante transformação, uma tentativa de melhor compreender os problemas atuais" (ALEIXO, 1999, p. 4-B).

\title{
1.2 A COMÉDIA DO TRABALHO (2000) E AS OFICINAS INTERNAS
}

\begin{abstract}
Não é uma dramaturgia coletiva no estilo da década de 60. Nós temos funções. Eu e o Márcio Marciano somos os dramaturgos que conduzem, mas os atores têm que aprender a pensar o conjunto da cena, eles vão aprendendo aos poucos a história antes de ensaiar uma cena, formalizá-la é uma última etapa. Tanto que a gente estreia uma matéria bruta que vai sendo aperfeiçoada depois da estreia. Assim, muitas vezes nós falamos para o ator mudar o tempo de uma fala na cena. As questões formais são às vezes discutidas depois que o espetáculo ganhou uma forma pelos atores, como tendência (CARVALHO, 1998, p. 5).
\end{abstract}

Neste trecho de uma entrevista dada pelo nosso diretor e dramaturgo em 1999, temos uma síntese de como operávamos àquela altura no grupo e foi o que basicamente aconteceu em A comédia do trabalho. Ela foi das mais abertas concepções à participação dos atores na feitura do texto e da encenação. Isso possivelmente se deu pelo fato de que o assunto, em sua maior parte, surgiu na sala de preparos. Tendo o tema do trabalho em mente, fomos convidados, como outras companhias vinham sendo, a realizar o projeto Residência Artística da Oficina Cultural Oswald de Andrade de São Paulo, para lá desenvolvermos uma pesquisa que envolvesse oficinandos/alunos em várias frentes, como direção, teoria crítica, atuação, cenografia e figurinos, iluminação, produção e vídeo-documentário. Além da equipe do Latão $^{36}$ havia 46 pessoas participando de um composto entre pedagogia e ensaios. Em conjunto com os alunos ou apenas entre nós do grupo, improvisávamos a partir de incursões a praças, terminais de ônibus, de conversas com gentes da cidade como catadores de papelão e homens-placa, palhaços locutores de portas do comércio etc. Apresentávamos como estudos, sem muita preparação, imitações de pessoas que encontrávamos nas ruas, pedaços de canções sobre as situações observadas, poemas pensados nos cantos dos espaços da Oficina Oswald de

\footnotetext{
${ }^{36}$ No elenco estavam: Adriana Mendonça, Alessandra Fernandez, Heitor Goldflus, Maria Tendlau e Ney Piacentini. (Em apresentações posteriores, entraram: Helena Albergaria, Gustavo Bayer, Beto Matos, Cátia Pires, Emerson Rossini, Izabel Lima, Victória Camargo, Ana Cristina Petta, Renan Rovida, Rodrigo Bolzan, Maurício Braz e Carlos Escher), a direção musical foi de Walter Garcia e Lincoln Antônio, com cenografia e figurinos de Marcio Medina, iluminação de Paulo Heise, preparação vocal de Sandra Ximenes, pesquisa técnica de Lauro Mesquita, vídeo-documentário de André Lopes, produção gráfica de Otávio Martins e Vera Padilha, coordenação de produção de Ney Piacentini, assistência de produção de Marcelo Vinícius, texto coletivo da Companhia do Latão e direção de Sérgio de Carvalho e Márcio Marciano.
} 
Andrade e vários outros fragmentos, meio reais meio fictícios, porém sempre inspirados no que tínhamos visto pela cidade adentro.

Os oficinandos também participaram do levantamento de material em exercícios coletivos, o que os unia aos atores do grupo. Por nossa vez, propúnhamos extratos potencialmente cômicos, como duplas, gêmeos e jogos clownescos. Outra fonte para as improvisações foram as gravações em vídeo trazidas pelo pessoal do audiovisual, coletadas em locais onde circulavam desempregados e trabalhadores precarizados, em cruzamentos de trânsito ou em ambientes de atividades informais.

Os diálogos com os alunos das oficinas foram importantes para os atores. Porque eles realizavam cenas ligadas ao tema do trabalho, e assim nós tínhamos um espelhamento. Sobre o modo de criação de cenas, no começo existiram dois processos: no primeiro os diretores sugeriam um tema e nós nos juntávamos para fazer uma cena coletiva. Depois se buscou que cada ator, a partir de uma fonte ou sugestão, elaborasse uma cena sozinho e a ensaiasse com as outras pessoas que acabavam interferindo, dando palpite e modificando a cena, mas a partir de uma base concreta (FERNANDEZ, 2000, p. 16).

A atriz Alessandra Fernandez se refere ao passo seguinte em relação a um início mais aberto, em que alguma organização se desenhava e assim surgiu um mosaico de pequenas cenas, coros, imagens, situações, tipos e músicas, porém sem um local, um cenário que os agregasse. Não sabíamos se situaríamos a futura peça em uma fábrica de penicos, em um supermercado ou em um banco, e uma série de testes compôs um panorama para que os diretores/dramaturgos fossem interligando as propostas e solicitando novas ideias.

Exemplificando, havia uma cena em que dois trabalhadores de um depósito de mercadorias conversavam sobre a ameaça de serem demitidos. Um deles ficava dentro de um elevador (imaginário) em movimento ascendente e o outro no nível térreo. Foi quando surgiu a forma de planos de altura diferenciados que mais tarde foi usada na peça em outro contexto, com os donos da empresa no alto e os desempregados e a massa da rua embaixo, porém sem uma cenografia que colocasse parte do elenco em cima de alguma estrutura. A visão de que alguns estariam no alto em relação aos demais seria dada pela simples convenção de os personagens de baixo olharem para cima e os de cima olharem para baixo, mas com todos os atores no mesmo plano no piso do palco.

Como o ritmo dos ensaios foi crescendo, os atores começaram a assumir, entre outras atribuições, a criação de alguns prováveis personagens, produzindo materiais que ampliassem os perfis de seus nascentes papéis. Adriana Mendonça pesquisava uma diretora de recursos 
humanos, que na realidade teria como principal função demitir funcionários, segundo a política de redução de quadros da empresa. Alessandra Fernandez voltou-se para uma telefonista solitária, cuja única razão de existir era o seu trabalho automático e repetitivo. Heitor Goldflus assumiu a personificação de um gerente que, apesar de ter sido preparado para ser um obediente seguidor das regras corporativas, tinha em si interrogações que destoavam das normas da reengenharia em implantação na firma em que tais figuras conviviam. Maria Tendlau passou a desenvolver uma estrangeira de uma organização não governamental (ONG) - a Srta. Liu Liu, interessada em ajudar o tempo todo os seus semelhantes. Eu fazia exercícios relativos a um funcionário demitido, nominado como Núlio, que se encontrava no topo do edifício da empresa prestes a se atirar lá do alto. E quando foi definido que o cenário das ações seria um banco, assumimos também outros papéis: Heitor Goldflus e eu, por exemplo, envolvemo-nos com a dupla Leonid e Creonid (Léo e Créo), donos de uma instituição financeira que estava em crise e cuja política interna de empregos estava sendo reformulada.

"Fomos para a rua, entrevistamos pessoas, pesquisamos em livros e jornais e assistimos ao material gerado pela oficina de audiovisual. As personagens nasceram dessa pesquisa" (MENDONÇA, 2000, p. 16).

Apesar da tendência à tipificação que vínhamos esboçando, uma preocupação passou a tomar conta dos ensaios de A comédia do trabalho: como dar dimensão àqueles rascunhos que, para além das aparentes caricaturas, vivificariam os seres que estavam ganhando relevo na peça?

"Desde o começo, estabelecemos que trabalharíamos com tipos. Eu, particularmente, resolvi carregar muito na tinta desses tipos para poder diferenciá-los, porque eu teria que fazer muitas personagens e depois, se fosse necessário, os humanizaria, tiraria seus exageros" (FERNANDEZ, 2000, p. 17).

E na medida em que idealizávamos nossos papéis segundo o que vinha das ruas, os personagens se vitalizavam. Porém, notamos uma discrepância entre a nossa imaginação de classe média ao imitarmos figuras do povo e quando mimetizávamos pessoas reais de baixa renda. Nossa postura era a de autocomiseração, enquanto, ao conhecê-los (saindo a campo ou assistindo-os em vídeo), notávamos que eles tinham uma visão de mundo diferente dos coitados que interpretávamos. Nesse sentido, em outra perspectiva, A comédia do trabalho se aproximava das observações de rua iniciadas em Ensaio sobre o latão (ver as p. 22-29). Ou seja, de um olhar mais apurado sobre problemas de uma realidade de emprego e desemprego, de trabalho e da falta dele, surgiram perfis de carne e sangue. Ficou claro para nós que, se 
fôssemos nos guiar somente pelos nossos referenciais, a peça não teria metade da riqueza e das contradições que vieram a tomar parte na dramaturgia final. A vida, a rua e as pessoas são sempre muito mais surpreendentes do que aquilo que supomos conhecer como artistas.

Destaco um acontecimento daquelas buscas que, a propósito, costumávamos contar em oficinas e debates que aconteceram depois da obra pronta. Ao seguirmos, com uma câmera de vídeo, um homem com cerca de 25/30 anos, que recolhia das ruas os mais variados tipos de papel em seu carrinho, fomos levados por ele para debaixo de um viaduto no centro da cidade. Segundo o depoimento dele, ali era a sua empresa, na qual promovia reuniões com a equipe (sua família, que esperava por ele), distribuindo as tarefas pela manhã e retornando ao final do dia para fazer o balanço do trabalho. Perguntamos como ele administrava o negócio e o homem declarou que tinha cartão de crédito e telefone celular (isso no ano 2000) e assim agilizava seu comércio. Não havia em seu rosto evidências de sofrimento, tampouco ele se colocava como um excluído do mercado. Ao contrário, ele enxergava pela frente boas oportunidades em seu ramo. Se nos fosse solicitado representar algum catador de papelões, provavelmente exibiríamos um pobre desvalido se lamuriando de sua condição miserável. Jamais imaginaríamos alguém como aquele homem, com atitude positiva mesmo diante de uma realidade que lhe era desfavorável.

Por outro lado, segundo Márcio Marciano, a personagem:

Ela até pode agir de uma forma em uma cena e agir de forma contrária na cena seguinte. É preciso deixar claro que a situação impunha um determinado comportamento a ela e, consciente ou inconscientemente, a agir de determinado modo. Acaba sendo um marco, quando o ator começa a fazer esta personagem de forma dialética, contraditória (MARCIANO, 2000, p. 16).

Nos casos originários das ruas, a contradição vinha da própria vida daquela gente que não esmorecia com sua precariedade e era precária em seu não esmorecimento. Por sua vez, as personagens de Adriana Mendonça - uma mulher que dizia: "Mesmo quando ele me bate em mim, eu tenho dó" (CARVALHO; MARCIANO, 2008, p. 103), e também um malucobeleza que pregava aos policiais um "viva o amor!" (CARVALHO; MARCIANO, 2008, p.132) em uma manifestação e deles apanhava - levavam o selo dialético justo por serem não sem discrepâncias. Espero ter deixado claro que a vertente contraditória na composição das personagens já vinha sendo apontada em obras anteriores do grupo e o que talvez tenha se acentuado em A comédia do trabalho foi antes uma cena dialética do que uma atuação 
dialética propriamente. Senão, vejamos um trecho da peça em que um banqueiro falava do alto do seu andar à multidão nas ruas:

LEONID (Grita ao povo na praça): Ei, vocês aí embaixo, aqui. (Tenta parecer um líder popular.) Companheiros, vocês sabem por que estão na miséria? Sabem por que aquele pobre-coitado está querendo se matar? É tudo culpa do governo. É o governo que não libera empréstimos para que possamos dar emprego a vocês. (A Créo que o puxa.) Me deixa, me deixa que eu estou inspirado. (Ao povo.) E tem mais, vocês têm que xingar, protestar e se revoltar para que o governo ajude homens ricos e honestos como eu a ajudar vocês (CARVALHO; MARCIANO, 2008, p. 118).

A impostura desse meu financista contrastava com a sua posição e, para chegarmos aessa fusão, improvisamos passeatas de gente rica, protestos em que eles exigiam cada vez mais luxo e congêneres. A inspiração para tanto veio de notícias de jornais e revistas que reportavam sobre as dificuldades que os milionários encontravam na contemporaneidade. Em outro momento da peça, víamos a preparação da tropa policial que iria combater uma manifestação. Experimentamos fazer o discurso de um coronel da Polícia Militar dando ordens de como os soldados deveriam se comportar no confronto com o povo. A reconhecível imagem de um militar autoritário e feroz ordenando seus comandados a agir com violência na repressão a uma agitação não nos satisfez por ser óbvia e sem oposições. Improvisando algumas vezes, colocamos na boca do coronel um discurso razoável e humano, que respeitava os direitos dos cidadãos de se indignarem por serem contribuintes, porém emitindo tais palavras de bom senso de um modo febril e raivoso. Foi assim que encontramos os contrapontos que buscávamos.

Mais complexo era o momento em que, durante os confrontos entre a polícia e o povo, um soldado dizia:

POLICIAL (Desabafa enquanto chuta um manifestante caído no chão): Sabe quanto eu ganho para trabalhar na polícia? Sabe quantos empregos eu tenho fora daqui? Sabe o que é fazer bico de segurança em casa de bacana? Só por isso eu vou me revoltar? Só por isso eu vou protestar? Só estou fazendo o meu trabalho (CARVALHO; MARCIANO, 2008, p. 132).

Note-se que a ação externa (espancar uma pessoa) se engastava com os ditames expostos por meio do que o soldado dizia e, assim, a razão se dividia. Não era admissível que ele batesse no cidadão, embora o que ele dissesse não fosse sem razão. Aqui a contradição se encalcava a ponto de condenarmos sua atitude, mas não as suas palavras. Podemos considerar 
que, nessa célula cênica, migramos da cena dialética coletiva para a ação dialética individualizada. Esclareço que, para mim, na cena dialética a disparidade dos vetores se dava no contorno da situação, na desvinculação do texto com a atitude dos papéis. Por sua vez, na atuação dialética, os personagens vivenciavam um descompasso maior entre o que eles faziam (ou sentiam) e o que professavam. Ou seja, a primeira modalidade era mais aberta que a segunda, cuja contradição era internalizada.

Por conseguinte, foi colocando forças em embate, quer em figuras individualizadas, quer em cenas de disputas entre os grupos sociais, que a peça ganhou um tom cômico no geral, embora seus personagens enfrentassem situações drásticas, contaminadoras dos gêneros da comédia e da tragédia. Como exemplo, tínhamos a sujeição de alguns personagens a condições depauperadas de trabalho, uma vez que aceitar uma função indigna seria relativamente melhor do que ficar desempregado. Em um quadro da peça em que eram feitas entrevistas com candidatos a vagas de emprego, uma mulher declarava ter como sonho de vida ser uma faxineira, no afã de conseguir uma colocação. O dissenso da cena não estava apenas nesse exagero, mas também no fato de que os entrevistadores exigiam da candidata o cumprimento de um rito que envolvia o preenchimento de formulários e a apresentação de um currículo para fazer faxina. O coro, comentador da situação, servia de elemento distanciador:

VENDEDORA DE SUCO: Olhe, dona, eu já entreguei o tal do curri...

ENTREVISTADOR 3: Calma, a senhora está muito tensa. Não quer declamar um poema? VENDEDORA DE SUCO: Um poema (Procura). "Palheirinha, palheirão, toma lá este dente podre me dê cá um dente são."

ENTREVISTADOR 3: Consta em sua ficha que a senhora tem dificuldade em lidar com as emoções. Por que a senhora foi demitida?

VENDEDORA DE SUCO: Fui eu que me demiti. É que no outro emprego, o patrão gostava de chamar a atenção da gente na frente dos outros, só para humilhar. E isso eu não admito. Se quer me chamar a atenção, me chama no cantinho.

CORO: Não culpe os outros por estar desempregado. Todo patrão quer escravos educados. ENTREVISTADOR 3: Precisamos de pessoas mais equilibradas. Obrigado (CARVALHO; MARCIANO, 2009, p. 101).

Essa personagem da vendedora foi uma das que, entre outras, veio das ruas. Maria Tendlau, a atriz que a fez surgir, começou imitando uma mulher indignada que se irritou (durante uma nossa gravação em vídeo sobre um grupo de desempregados) com o descaso do qual ela era uma consequência. E, por Tendlau ter se mirado em uma pessoa de verdade, sua persona se tornou sanguínea e vivaz. 
Destarte, A comédia do trabalho resultou que:

\begin{abstract}
No auge do capitalismo financeirizado, um banqueiro depende da ajuda governamental para vender seu negócio a um investidor estrangeiro. Um desempregado, em meio às massas de demitidos, tenta suicidar-se no alto da empresa em que trabalhou. Uma representante da Missão Filantrópica Internacional viaja ao trópico para oferecer sua ajuda. A massa de miseráveis da grande cidade se move caoticamente entre a insatisfação, o desespero e a rebeldia. Os capitalistas e policiais se deparam com a necessidade da ação coletiva. O assistencialismo cultural pode ser um bom negócio ${ }^{37}$.
\end{abstract}

Para constituir tal síntese, cobrimos praticamente todo o espectro social durante as pesquisas do processo. No primeiro semestre do ano 2000, entrevistamos banqueiros, exministros de Estado, sociólogos, especialistas em gerenciamento de pessoas, psicólogos que atendiam executivos responsáveis por demitir funcionários, desempregados, sindicalistas e moradores de rua. Outras fontes como livros a respeito de políticas de recursos humanos (incluindo uma obra que estava na moda à época $O$ Ócio Criativo, do pensador italiano Domenico de Masi) proporcionaram um repertório que nos permitiu criar um contexto em que estavam presentes todas as classes sociais do país.

Desse panorama foi possível teatralizar o amplo extrato socioeconômico nacional, perante um tempo em que o emprego e o trabalho eram muito valorizados, justo pela sua falta. O Brasil de então estava com uma alta taxa de desemprego e o espetáculo fez um enorme sucesso por levantar um tema premente. Por oposição, permanecemos em cartaz por mais de uma década, com alta repercussão junto ao público, uma vez que a questão da empregabilidade no país não evoluía.

Outro efeito do processo sobre nós, atores, foi a revisão do nosso olhar quanto à dinâmica das relações de trabalho no setor cultural. Em A comédia do trabalho, fizemos uma espécie de autocrítica sobre a profissão de artista que, sem uma reflexão maior, em nada se diferencia da atual avassaladora mercantilização do ser humano por consequência de uma economia capitalista cada vez mais financeirizada. Também nós somos e muitas vezes nos portamos como uma mercadoria em circulação dentro do universo da cultura e da comunicação. E pior, chegamos a nos colocar à venda, posto que a mecânica vigente trata a arte como um produto, o espectador como um consumidor e a difusão de uma obra teatral como estratégia de marketing.

37 Companhia do Latão. Na página Espetáculos, sobre A comédia do trabalho. Disponível em: <www.companhiadolatao.com.br>. Acesso em: 09 abr. 2016. 
Foi preciso ouvir e investigar as reflexões dos nossos interlocutores, ler e comparar a literatura sobre o assunto, para estabelecer uma consciência crítica e dialética sobre o tema. Perceber que, quando nos vemos fracassados individualmente como artistas, por não sermos reconhecidos, isso se deve menos ao fato de sermos incapazes do que ao fato de estarmos inseridos em um ambiente que prima pela competitividade extremada, pela exclusão e pela eleição de valores que submetem os indivíduos à lógica do vencedor versus o perdedor máxima do modo de vida das sociedades em que o capital contamina todas as relações.

O que explico é que na Companhia do Latão somos antes um grupo de estudos, de aprendizes e curiosos que, ao longo do convívio, fomos assimilando conhecimentos e uma visão sobre os fenômenos da vida. Isso nos forneceu instrumentos para entender um pouco mais a nossa posição como trabalhadores da cultura e como cidadãos em um país que ainda não firmou sua identidade. Foi, e continua sendo, uma contínua assimilação de como agir diante das dificuldades e, ao mesmo tempo, de como nos posicionarmos para que algum avanço aconteça individual e coletivamente.

Trata-se de um projeto político, sem dúvida, e, como tal, considera os indivíduos e seus dilemas dentro das faixas sociais a que pertencem. Somos uma companhia de teatro de esquerda, porém estamos no mundo da mercadoria e sofremos os paradoxos inerentes à nossa posição. Todavia o que não queremos perder de vista é a possibilidade de, mesmo em tempos de violentos retrocessos, levar em conta valores como a solidariedade, a justiça social e a igualdade econômica.

Especificamente a respeito da minha atuação em A comédia do trabalho, houve uma autoironia, pois procuramos também expor o nosso afã por espaço na publicidade e na televisão. Em improvisações que revelavam os embaraços dos intérpretes nesse ambiente, surgiu uma pista: um depoimento proposto pela dramaturgia sobre a minha condição de ator de teatro político. Eu recitava um pequeno poema ${ }^{38}$, emitido em estilo shakespereano, que colocava em oposição um intérprete optante pela cena engajada, que muito pouco lhe rendia, em relação a um período em que não ganhava tão mal fazendo anúncios de produtos do mundo do consumo. Por cômico que fosse, não deixava de ser incômodo perceber que, sem ter passado pela Companhia do Latão, talvez eu não tivesse obtido aquela visão de que, na televisão, com raras exceções, somos meros veículos para a difusão do desenfreado incentivo

\footnotetext{
38 "Sou um ator de teatro/ Apesar do amor ao ofício as contas de casa não pago com isso/ Tenho saudades do dia em que era um ator mercadoria/ Fazia anúncios vinhetas reclames, vendia carros, viagens, salames/ E tudo fazia sentido, porque o meu cabelo não tinha caído/ Cheguei mesmo a pensar que a vida era bela quando fiz o papel de garçom numa telenovela/ Alguém aí tem outro emprego que volte a me dar sossego?/ No mundo da mercadoria, coisa má é não ser mercadoria" (CARVALHO: MARCIANO, 2008, p. 119).
} 
aos negócios. Noutra banda, ficou reforçada a consciência de que, ao escolher o teatro, eu teria que encontrar meios alternativos para sobreviver.

A comédia do trabalho foi apresentada em teatros, para o MST, em sindicatos, associações comunitárias e escolas, além de festivais em diversas cidades do país e ainda em Portugal. Se por um lado ela nos trouxe muita satisfação por ir longe, por outro deixava em nós, e possivelmente no público, alguns dissabores, como a narração distanciada que eu fazia do meu personagem Núlio, próxima do fim do espetáculo:

No oitavo mês de desemprego

Núlio poderia ter dito

Que andando pelas praças

Ouviu muitas histórias, de vidas começadas na esperança

Quando os homens ainda têm bons estômagos

$\mathrm{E}$ as mulheres não ensaboam os cabelos nas águas da sarjeta

Poderia ter dito que viu abrir à sua frente um abismo profundo

e imenso

E viu a si próprio

Agarrado às paredes escorregadias

Dobrando os dedos para que as unhas não quebrassem.

E percebeu que todos os dias

Fez tudo o que diziam ser certo

Até a exaustão.

Talvez tenha sido este o seu engano:

Pensar que sofria sozinho

Que o trouxe tão baixo no fundo do abismo.

Núlio poderia ter dito, mas não disse (CARVALHO; MARCIANO, 2008, p. 135). 


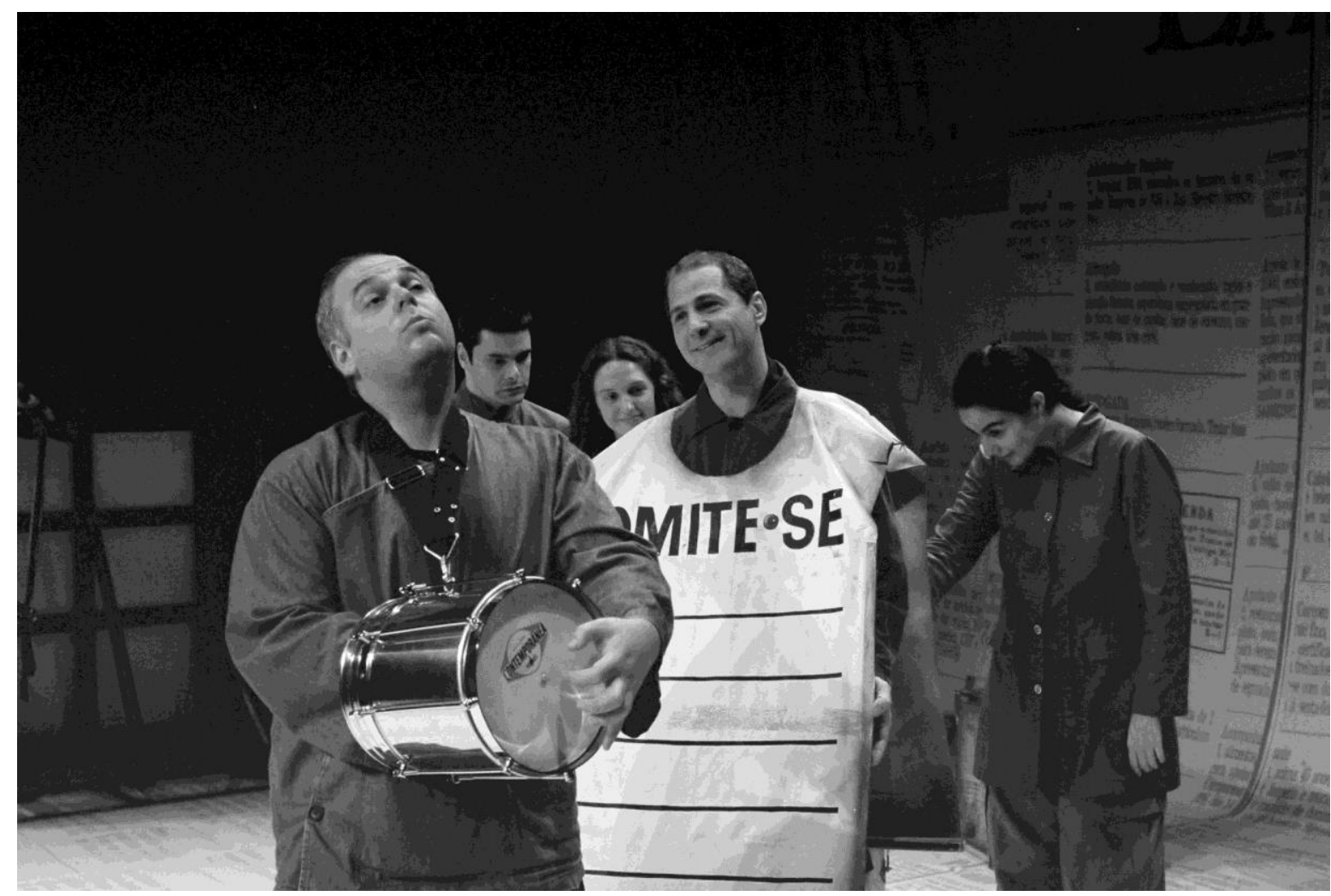

Heitor Goldflus, Gustavo Bayer, Helena Albergaria, Ney Piacentini e Alessandra Fernandez. A comédia do trabalho, 2000. Foto: Douglas Estevam.

Parar para estudar

Nos últimos anos, ele fala muito de Stanislavski. Especialmente sobre os últimos textos de Stanislavski, publicados em 48 e 49, em Moscou, sobre a importância das ações físicas. É por aí que Brecht pegou Stanislavski. Não foi banhado na emoção, ou coisa que o valha, à moda do Actor's Studio. É a ação física de Stanislavski que interessa. Agora, que há uma abertura para a subjetividade, isso há. Nos próprios personagens. A subjetividade em Brecht é sempre uma coisa muito lenta e arduamente conquistada (BORNHEIM, 1997, p. 4).

"Por outro lado, o grupo está sentindo a necessidade de recuperar alguns princípios de trabalho do ator. Voltar a estudar algumas coisas de Stanislavski, as quais Eugênio Kusnet também trabalhava no Teatro de Arena" (CARVALHO, 1998, p. 6).

Após A comédia do trabalho, antes de iniciarmos um novo processo que chegaria ao Auto dos bons tratos, elenco e diretores da Companhia do Latão se reuniram para praticar alguns procedimentos retirados do Sistema de Stanislavski. Não havia uma premência de se estudar a interpretação realista gestada no Teatro de Arte de Moscou, mas a coordenação do 
grupo propôs que nos dedicássemos alguns dias para visitar aquela pedagogia atoral russa. Nessa oficina interna, passamos a nos exercitar de maneira muito simples, andando pela sala, embora já aí com um diferencial: não caminhávamos abstratamente, ou seja, quem caminha tem algum objetivo, mesmo que seja o de devanear.

E se uma pessoa tem sempre muitas coisas em mente enquanto se desloca, neste que é um dos exercícios recorrentes nos mais variados processos teatrais (andar pelo espaço), iniciamos uma espécie de preenchimento interno do ato de andar. Assim, as nossas caminhadas pelo espaço começaram a ser providas de pensamentos sobre este ou aquele estado interno de alguém, o que consequentemente modificava o tempo-ritmo do se mover. Quem tem um compromisso e está atrasado não caminha do mesmo modo de alguém que vai a um encontro amoroso. Agir como na vida real nos pareceu mais concreto do que as abstrações de caminhar feliz ou angustiado, sem uma situação que subsidiasse o andar. Ou seja, se andamos de modo rápido, porque o faríamos? Quanto tempo temos para chegar ao destino? De onde viemos e o que especificamente vamos fazer quando chegarmos? São inúmeras as perguntas a serem levantadas, a fim de que o caminhar não se esvazie.

Em um segundo momento nesses exercícios básicos, começamos a pensar em contradições, a princípio apenas físicas, como olhar para cima visualizando o que estava abaixo e andar para trás para ir ao encontro de alguém à nossa frente. E essas apostas não eram apenas formais, uma vez que alguém poderia estar tão preocupado com determinado problema, com tantos e perturbadores pensamentos a ponto de isso provocar uma movimentação exterior vagarosa, fazendo com que o deslocamento de uma pessoa com intensa atividade mental fosse lento.

O mesmo princípio foi aplicado em outra prática em que uma atriz ou um ator permanecia absolutamente parado, porém imaginariamente envolvido em uma situação extrema. Por exemplo: um colega contava para um ator voluntário (sentado em uma cadeira), sem que os demais ouvissem, que havia um corpo morto à sua frente e ele não sabia o que fazer com o cadáver. Quem executava a ação deveria apenas pensar no problema sem demonstrar nada externamente. Era um exercício de ação internalizada no qual haveria alta atividade psíquica, mas que não se traduziria em gestos ou palavras. Os colegas (sem conhecer o enunciado) que assistiam o ator executor do exercício depois opinavam sobre o que estaria acontecendo naquela situação. Mas não se tratava de um jogo de adivinhação. $O$ intérprete se concentrava rigorosamente em um problema e os demais simplesmente o observavam. Era um treino para a imaginação apenas e não uma representação teatral. $\mathrm{O}$ desafio consistia em que quanto mais o ator se envolvesse na tarefa, mais claro ficaria o 
problema para quem o assistisse, sem a necessidade de ilustrá-lo sonora ou fisicamente. O fluxo de consciência da pessoa deveria ser substituído pela capacidade do ator de figurar sobre a situação.

Na mesma linha de pesquisa, foi testada uma proposta de improvisação retirada do livro A poética da pedagogia teatral, de Maria Knebel, assistente de Stanislavski:

O cenário está escuro. Ao fundo se escutam vozes. Abre-se a porta e entra uma mulher com bolsas e uma mala e acende a luz. Atrás dela aparece um taxista que leva uma mala grande. O diálogo nos intera que eles vêm de um lugar longe. Que faz frio na rua e que a mulher tomou o táxi em um lugar em que a deixou um ônibus. A mulher expressa ao taxista seu agradecimento por ele tê-la levado. Ele a está escutando, mas não se retira. A ela parece que já é hora de que ele se vá, porém ele parece esperar algo. “O que quer é uma xícara de chá. Deve estar gelado como eu." Ela se retira para pegar o chá. O taxista se põe a observar a habitação, pensativo. "Desculpe, mas não tenho com que acompanhá-lo...", diz ela sobre o chá.

O taxista está perturbado. “Obrigado, já é muito tarde, devo voltar para casa.” Mas ela já o serviu e o condutor deve aceitar a xícara. A jovem se inquieta. Não há mais ninguém na casa e já é noite alta. O taxista está também nervoso, mas não se move do seu lugar. Por fim o homem não se aguenta e pede que ela pague o que lhe deve. Subitamente ela se lembra de que não havia pago a corrida. Pensava que tinha lhe dado o valor da viagem quando ele havia deixado a mala quando a ajudara, mas se esqueceu. Incômoda, se desculpa. Dá-se conta de que seu medo era infundado. $\mathrm{O}$ condutor se sente incômodo por ter tido que lembrá-la de que não o havia pago. Ao mesmo tempo, ele está aliviado em saber que a mulher não o tinha enganado. Ele abandona a casa contente e agradecido (KNEBEL, 1999, p. 72).

Em uma das tentativas de se executar o que foi descrito acima, o ator Otávio Martins, ao entrar no apartamento na pele do taxista, enquanto a mulher ia à cozinha pegar um copo com água (em lugar do chá), sentou-se como se houvesse um sofá na sala. Essa atitude fez com que o diretor Sérgio de Carvalho comentasse que um taxista que estaria esperando o pagamento pela sua corrida não se sentaria, a não ser que ele estivesse certo de que receberia pela corrida, ou que esquecesse que estava cansado por ser tarde da noite ou ainda pelo taxista ser um tanto espaçoso. Nessa última possibilidade é que estaria o problema. Otávio investira em um tipo - o taxista folgado e não em seu estado interno com suas dúvidas sobre o momento. Ou seja, o ator imprimira ao papel características exteriores, com uma figura que foi se alargando em um apartamento que não conhecia, em vez de uma pessoa que se indagava sobre o que estava se passando com aquela mulher que não lhe pagava a corrida. $\mathrm{O}$ 
equívoco de Otávio é (penso) comum entre nós: ao invés de nos atermos aos pensamentos do personagem em uma situação, partimos para atitudes que nem sempre expressam as reais preocupações do papel. Para corrigir aquele desvio, Sérgio sugeriu que Otávio fizesse um taxista tímido, o que acarretou em outro tipo, contrário do anterior. Mais tarde, nosso diretor se deu conta de que a indicação dada ao ator fora errônea, justo por priorizar um viés tipificador e não vivencial. E que era preciso investir na visualização do apartamento, por exemplo, para que o ator se ativesse aos fatos em curso, não se preocupando com este ou aquele dado demonstrativo do personagem.

Quando eu fui fazer o mesmo exercício, tentei preencher os espaços vazios da cena puxando assuntos com a passageira, comentando sobre o clima, que já era tarde, se fazia tempo que ela morava naquela casa e assim por diante. Tudo isso não tinha relação com a situação proposta. Novamente era o ator tentando manter o funcionamento da cena e não vivenciando, naquele momento, as circunstâncias entre o taxista e a mulher. Os personagens estariam lacônicos porque cada um se questionava (em silêncio) sobre o que poderia estar acontecendo com o outro: a mulher, sem se dar conta de que ainda não pagara o taxista, tinha dúvidas do porquê ele não ia embora, pensando talvez que aquele homem pudesse querer alguma coisa a mais com ela, como uma aproximação física, o que poderia provocar nela um receio dele. O taxista, por sua vez, tentando entender aonde aquela mulher queria chegar não lhe pagando e não sabendo como dizer isso a ela. O problema estava na imaginação de cada um dos dois personagens e era improvável que o taxista se pusesse a falar se estava quente ou frio, ou algo do gênero. Não havia essa necessidade de povoar a cena com outras ações que não as que estavam se passando internamente com eles. Como Otávio Martins, eu quis resolver o problema da cena por fora, não entrando nela. Em outras palavras, éramos atores ansiosos em fazer alguma coisa e não o taxista duvidando dos acontecimentos à sua frente.

Em algumas das oficinas que fazíamos, quando propúnhamos esse exercício, era recorrente (como eu mesmo o fiz) que alguns voluntários se pusessem a falar sem parar no improviso. Esse desvio não é um problema de um ou outro intérprete. Acredito ser comum considerar que atuar é encontrar frases e sentenças que mantenham uma cena aparentemente em movimento. Mas agir não é só falar, é antes pensar, refletir sobre o que está acontecendo como quem se envolve em uma ocorrência, como se ela fosse verdadeira. É preciso se perguntar sobre uma série de fatores para que uma improvisação se aproxime de alguma verossimilhança cênica. Um taxista que sobe as escadas de um prédio levando as malas de sua passageira está mais atento à dificuldade de carregar aquele peso ou em conversar com sua freguesa? Ao entrar no apartamento pela primeira vez, o taxista repara no tamanho do imóvel, 
no mobiliário e sente o cheiro de uma casa fechada há dias ou não? Ele se põe a se perguntar se aquela mulher vive sozinha naquele lugar? Ou seja, existe uma série de indagações silenciosas que podemos supor enquanto estamos atuando que venham a provocar as ações internas dos personagens, sendo as palavras, muitas vezes, dispensáveis.

A própria Maria Knebel trata desse problema em O Último Stanislavski: "Ele estava convicto de que o ator pode chegar à palavra viva apenas como resultado de um grande trabalho preparatório que o leve a valorizar as palavras como algo imprescindível para expressar as ideias de um personagem" (KNEBEL, 2013, p. 24).

Não que a palavra, para Stanislavski, não tenha importância, mas ela germina motivada pelas ações psíquicas que a antecedem, como cita a pedagoga russa sobre seu mestre no trecho acima. É evidente que só nos damos conta dos problemas das nossas performances nos dispondo a entrar no jogo e provavelmente errando, afinal, trata-se de experiências. Ninguém espera acertos nas primeiras investidas. O acúmulo de erros e suas revisões é que podem fazer com que as improvisações melhorem até atingirem um grau satisfatório do envolvimento procurado. Para tanto, em uma situação cênica, como o caso do taxista e da passageira, é recomendável levantar as informações que envolvem o problema: Em qual cidade vivem os dois? Com que ela trabalha? Qual o motivo da viagem dela? Em qual horário se dá a chegada da dupla no apartamento da mulher? Como seria a arquitetura do prédio e assim por diante. Esses dados auxiliam na constituição do episódio entre os personagens, dando-lhes realidade. Durante o jogo, é aconselhável se portar como as duas figuras fictícias, de acordo com as circunstâncias propostas ${ }^{39}$, e não como intérpretes que buscam a manutenção de um falso ritmo da cena. Alimentar o pensamento com perguntas que o taxista e a mulher se fariam sobre o que o outro teria em mente provavelmente levaria ao enleio requerido. As ações internas dos papéis é que provocariam alguma motivação na relação. Não uma movimentação dos atores pelo espaço, porém aquilo que pode fazer com que o espectador acompanhe os desassossegos dos envolvidos na cena.

Os exercícios que acabamos de discutir funcionaram como estímulos à nossa imaginação e estabeleceram uma plataforma realista, na qual se assentou, ao longo dos anos, o trabalho dos atores da Companhia do Latão. Não seguiríamos à risca os preceitos stanislavskianos em todos os nossos projetos, porém os teríamos como uma referência. E tanto mais compreendíamos o realismo matizado, nuançado, que levasse em conta os

\footnotetext{
${ }^{39}$ Circunstâncias propostas: termo criado por Constantin Stanislavski para designar os dados e as informações que circundam um personagem e uma cena.
} 
pormenores das situações e as minúcias sobre os personagens, quer em ensaios, quer nas encenações para o público, mais preparados estaríamos para nos distanciar desse suporte e tentar entender como Brecht lidou com Stanislavski.

\section{A dialética para o ator}

Ainda que Brecht tenha, em distintas fases, criticado Stanislavski, nós nos interessamos pelo período em que houve uma conexão angular entre eles. E, se desde o início da história da Companhia em 1997, já não víamos o dramaturgo alemão como o oposto do ator e diretor russo, a partir de 2001 nos voltamos ao uso que Brecht fez de partes do Sistema de Stanislavski, notando inclusive que este último já ensaiava alguns princípios da dialética em sua concepção sobre a atuação. Se tomarmos a citação de que “[...] uma mãe, na melancolia da doença de um filho de trinta anos, enxerga a coragem dele de toda uma vida" (STANISLAVSKI, 2012, p. 112), teremos um indicativo dialetizante do que mais tarde se sofisticaria, como veremos a seguir. É o caso também da opção que Constantin Sergueievich fez por Anton Tchekhov, em cuja obra o que se passava na aparência dos personagens diferia dos seus sentimentos. Colocar em oposição as ações internas com as externas bem poderia caber no modo como Brecht via o trabalho com seus atores. E até mesmo servir como estímulo para que o poeta germânico viesse a escrever personagens paradoxais como foram os casos de Mãe coragem, de Galileu Galilei, de Grusha e Azdak em O círculo de giz caucasiano, ou Matti de Altonen e o próprio Senhor Puntila de $O$ senhor Puntila e seu criado Matti. São figuras que pensam de uma maneira e agem de outra, e vice-versa. Se Brecht e Stanislavski levavam em conta a contradição na composição dos papéis teatrais, encontramos entre eles um campo comum.

Contudo, uma das maiores evidências da aproximação entre Brecht e Stanislavski para mim o dínamo da nossa atuação dialética - está presente no artigo "O que se pode aprender de Stanislavski", escrito por Brecht e publicado no livro O Evangelho de Stanislavski, organizado pelo mexicano Sergio Jimenez. O autor de Aquele que diz, aquele que diz não lembra um conselho de seu colega russo que consiste em "Mostrar a mesquinharia de alguém no instante em que este alguém procura ser generoso... Não mostrar a raiva, porém os esforços para dominá-la; não demonstrar a volubilidade do ébrio, mas seus esforços em parecer sóbrio" (BRECHT, 1990, p. 230). Quando representamos um bêbado, comumentemente buscamos sua malemolência corporal e uma voz pastosa. Todavia, por vezes, quem está alcoolizado procura exprimir que não está tão alterado pela bebida. $\mathrm{O}$ mesmo se pode constatar nas emoções. Um ator quase sempre quer chorar em cena quando 
seu personagem se comove. No entanto, na vida pode acontecer o contrário, que é escondermos nossas constrições. O que existe é uma luta entre o que está se passando internamente em nós e o que exteriorizamos. São forças antagônicas em ação dentro da nossa mente e corpo.

Desfeita a separação entre os dois teatrólogos, no grupo seguimos praticando para entender a junção entre Brecht e Stanislavski relativa à interpretação. Pensando nisso, fizemos, nessa mesma fase de estudos independentes de estarmos montando uma peça, o seguinte improviso: dois atores ocupavam o centro da cena. Um era delegado e o outro seria o interrogado. A regra do jogo era a de que o primeiro teria que pressionar ao suspeito sem usar de violência. $\mathrm{O}$ ator incumbido de fazer o delegado não poderia agir, evitando o lugar-comum, de asperezas. Contrariamente, ele deveria tratar bem o interrogado, sem deixar de, subliminarmente, intimidá-lo. Depois de algumas tentativas, chegamos ao que se segue, em uma demonstração de que é possível realizar o pretendido:

\section{DELEGADO: Está tudo bem com o senhor? \\ INTERROGADO (Silêncio.)}

DELEGADO: O senhor tem notícias da sua família?

INTERROGADO (Estranhando a pergunta.)

DELEGADO: Pois eu soube que todos estão muito bem, inclusive sua filha pequena.

INTERROGADO: O que isso quer dizer?

DELEGADO: Que ela é muito bonitinha e carinhosa e eu espero que continue assim.

INTERROGADO: O senhor esteve na minha casa?

DELEGADO: Para uma visita amigável e fiquei encantado com sua menina. Tamanha graça que ninguém teria coragem de fazer mal a ela...

Independentemente da fidelidade da transcrição acima, a pressão de um personagem sobre o outro não se deu de forma direta e explícita, embora houvesse por parte do delegado uma ameaça encoberta contra a filha do interrogado. Procuramos outros exemplos para o exercício, como o de um chefe que agradaria um funcionário que seria por ele demitido ou alguém que trata mal outrem por não conseguir expressar o seu afeto. Quero dizer, variáveis de um mesmo propósito: dizer uma coisa e pensar/fazer outra, assim como o seu oposto.

Atuar dialeticamente não é algo imediato, visto que a nossa formação cênica em geral (como na vida) é dualista, geralmente apartando as tensões envolvidas de um determinado fenômeno e as colocando umas contra as outras (o bem combatendo o mal). Reverter essa tendência exige que passemos mais tempo agindo dialeticamente do que não o fazendo, de 
sorte que se temos como aumentar a nossa presença no chão dos espaços de trabalhos artísticos, manter um contato maior com uma literatura que nos reeduque através de paradoxos, entre outras iniciativas, é de se esperar que a representação contraditória, teatralmente vivificadora, tenha mais chances de se expandir em nossos projetos.

Como consequência, creio ter sido em uma oficina ministrada aos integrantes do Movimento dos Sem Terra que reparei haver uma ênfase ainda maior no princípio da contradição, o qual já vinha sendo sondado em nossas peças e atividades pedagógicas. Desde os aquecimentos até a elaboração das cenas, as antíteses estiveram em uso naquele convívio com o MST, o qual resultou em uma peça de curta duração, posteriormente publicada em livro $^{40}$ : em um tribunal, um camponês é julgado culpado por falta de heroísmo ao ter se fingido de morto (para escapar da morte) durante o massacre de Eldorado dos Carajás em 1996. A assimilação da contradição como método de trabalho para a constituição da cena criada pelos jovens do movimento foi tamanha que os levou a pensar e atuar paradoxalmente. Não sendo suficiente que a figura julgada tenha se passado por morto para viver, o sobrevivente seria condenado por não morrer como mártir e por ser considerado como covarde pelo ato de ter permanecido vivo. Recuperei essa vivência em que estivemos ao lado dos jovens camponeses porque eles nos ajudaram a ver mais claramente que a dialética teatral pode gerar consequências salutares, tanto no nosso grupo quanto em quem nós tivemos como parceiros em distintos períodos.

Anos depois, Sérgio de Carvalho apareceu na sala de ensaios com o livro La ligne des actions physiques ${ }^{41}$. Dele, fizemos dois exercícios de acordo com a descrição abaixo:

1. Entrar pela porta:

a. Para reencontrar os próximos e os amigos.

b. Para conhecer e se apresentar a desconhecidos.

c. Para se isolar.

d. Para evitar um reencontro desagradável.

e. Para surpreender e agradar pela sua chegada repentina.

f. Para causar medo.

g. Para observar, sem dar a impressão de interferir, aquilo que se passa na sala.

h. Para reencontrar a sua amada ou um amigo.

\footnotetext{
${ }^{40}$ A farsa da justiça burguesa, com redação final de Sérgio de Carvalho a partir da proposta do Grupo Filhos da mãe... terra do MST, que faz parte do volume: COLETIVO NACIONAL DE CULTURA - BRIGADA NACIONAL PATATIVA DO ASSARÉ (org.). Teatro e transformação social - Vol. 2 - Teatro Épico. São Paulo: Centro de Formação e Pesquisa Contestado, 2006.

${ }^{41}$ AUTANT-MATHIEU, Marie-Christine. La ligne des actions physiques. Paris: L’Entretemps, 2007.
} 
i. Para introduzir um homem desagradável ou perigoso (inimigo, trapaceiro, desconhecido que bate à porta).

j. Para compreender se tem ou não alguém atrás da porta.

2. Saudar todo mundo:

a. Para se mostrar acolhedor.

b. Para mostrar a todos a sua superioridade.

c. Para mostrar-se chateado.

d. Para atrair gentilezas, para lisonjear.

e. Para fazer de modo a não atrair a atenção.

f. Ao contrário, para exibir-se, para atrair a atenção.

g. Para mostrar que se é um próximo, um familiar, um íntimo.

h. Para fazer rir, alegrar, animar a sociedade com a sua entrada.

i. Para exprimir silenciosas condolências.

j. Para tratar imediatamente dos seus negócios. (PIACENTINI; FÁVARI, 2014, p. 115 $116)^{42}$.

Ambos são para ativar as ações internas, para nos levar a pensar em cena do ângulo dos personagens e praticar a abstenção do que é redundante em cena. Se de fato observamos, é precisar confiar que estamos agindo ainda que não verbalizemos. E o que Sérgio de Carvalho acrescentou a esses exercícios stanislavskianos foi uma camada dialética, do gênero: saudar a todos procurando esconder a timidez ou se fazendo parecer tranquilo. É perceptível que nos exemplos carvalhianos são precipitados os contrastes, uma vez que para parecer tranquilo tem-se que estar intranquilo e para disfarçar a timidez é preciso demonstrar-se extrovertido.

Tivemos também, em outras fases, encontros com Peter Palitzsch, colaborador que esteve próximo a Brecht a partir de 1949; com Alexander Stillmark, que também foi parceiro do dramaturgo alemão e com Hans Thies Lehmann, conhecido por sua teoria sobre o teatro pós-dramático. Da oficina que Palitzsch nos deu, em setembro de 1998 (no e com o apoio do Goethe-Institut de São Paulo), foram feitas anotações por integrantes da Companhia, das quais reproduzo uma parte:

\footnotetext{
${ }^{42}$ A tradução para o português dos exercícios contidos no livro La ligne des actions physiques, de MarieChristine Autant-Mathieu, foi feita por Ana Paula Zanandréa para o livro STANISLAVSKI revivido (org. de Ney Piacentini e Paulo Fávari).
} 
- A diferença entre a forma épica e a forma dramática na interpretação é quase impossível de se distinguir conscientemente. São duas formas semelhantes. Não existem modos de se epicizar. Nos pequenos detalhes de comportamento está a diferença.

- Sugestão de procedimentos épicos: dizer o texto na terceira pessoa, usar a linguagem popular, dialetos regionais, porque neles estão presentes as raízes do idioma. Coisas que atendam ao objetivo de tirar a dramaticidade das falas. Anular o pathos da personagem. É bom ouvir Shakespeare em dialeto.

- O procedimento épico, antinaturalista, consiste em apontar a realidade ao espectador. $\mathrm{O}$ efeito de distanciamento é fundamentalmente mostrar um evento como um "momento histórico" [...] A questão da emoção não é suprimi-la. Mas sim: contra o quê e para quê se canaliza essa emoção. Os atores do teatro épico também precisavam manifestar temperamento, paixão e contradição dentro de si para que a encenação não fosse seca.

- O início da dialética é a surpresa, o espanto. Devemos procurar no teatro esses momentos em que a lógica é superada, devemos procurar uma imagem que se inscreva na memória (PALITZSCH, 2006, p. 40-41).

Pelas afirmações do colaborador do Berliner Ensemble, distanciar não pressupõe um meio definido, uma técnica, mas um veículo para mudanças. O que não exclui os sentimentos, embora requeira certa dosagem para transitar na fronteira entre o dramático e o épico. Proveitoso também foi o último tópico sobre a surpresa na dialética, pela sua simplicidade e objetividade pois, pelo meu entendimento, dialético também pode ser o que se apresenta como inusitado e marcante. E o assistente de Brecht ainda diria: "Se o ator não investir toda a sua energia para representar esse papel como psicologia, ele estará um pouco fora dele e assim terá condições de mostrar a viabilidade de um comportamento diferente" (PALITZSCH, 2006, p. 40-41).

Ou seja, distanciamento como descolamento da verve do personagem. Contudo, os comentários de Peter Palitzsch, de certa forma, aproximam-nos da questão de sermos ou não, na Companhia do Latão, atores épicos e não dramáticos. Pois, a exemplo das obras de Brecht, tanto atuamos através de diálogos (forma dramática) quanto nos utilizamos de narrativas (uma das formas épicas), além de provocarmos o distanciamento por outros meios (até pelo transbordamento da própria forma dramática: uma cena dialogada pode ser exagerada ao ponto de o espectador desconfiar daquilo). E quando estamos atuando vivencialmente, não pensamos em ser épicos. Ou seja, o nosso solo para quando não estamos distanciados em cena é stanislavskiano, realista, mas de uma verossimilhança interrompida, visto que nossas dramaturgias são descontínuas em relação à tradição do drama. Também é verdade que ouvimos muitas vezes da nossa direção para representarmos como quem cita o texto, a fim 
evitar os excessos de dramatização em cena. Assim como, entre outros modos de representar, quebramos o formato de contracenarmos de frente uns para os outros, para ficarmos paralelos entre nós e frontais aos espectadores, mesmo quando estamos dialogando.

\begin{abstract}
$\mathrm{O}$ ator em cena jamais chega a metamorfosear-se na personagem representada. $\mathrm{O}$ ator não é nem Lear, nem Harpagon, nem Scheik, antes os apresenta. Reproduz suas falas com a maior autenticidade possível, procura representar sua conduta com tanta perfeição quanto sua experiência humana o permite, mas não tenta persuadir-se (e dessa forma persuadir, também, os outros) de que neles se metamorfoseou completamente. Será fácil os atores entenderem o que se pretende se, como exemplo de uma representação sem metamorfose absoluta, indicar-se a forma de representar de um encenador ou de um ator que estejam mostrando como se deve fazer determinado trecho de uma peça. Como não se trata do seu próprio papel, não se metamorfoseiam completamente, acentuam o aspecto técnico e mantêm a simples atitude de quem está fazendo uma proposta (BRECHT, 1978, p. 81-82).
\end{abstract}

Não me foi imediata a absorção dessa ótica atuativa brechtiana. Podemos falar em ao menos uma década para que eu começasse a compreender que a metamorfose total do ator em personagem, até então uma meta para mim, não seria necessariamente um ideal. De mais a mais, o que estava em questão era a renúncia de veleidades pessoais em função dos nexos artísticos.

Todavia, quando eu atingia um grau de transformação considerável em um papel, apegava-me a ele, recuando apenas quando o nosso diretor reiterava para que, em algumas ocasiões, atuássemos de forma indicada, citada, como nas primeiras fases dos ensaios, em que ainda estamos estudando os materiais. Assim sendo, é possível observar uma redução de possíveis desmedidas, o que faz com que a compreensão da cena fique mais clara. Ou seja, o distanciamento é possível não somente através da quebra do fluxo dramático por uma narrativa, por uma música ou interferência de outro personagem, como ainda via a atenuação do índice de transferência dos atores para os seus papéis. Apesar disso, lembremos que nessa equação teríamos que incluir a influência da escola stanislavskiana de interpretação sobre o nosso trabalho, para ficar mais próximos das operações atorais na Companhia.

A experiência com Alexander Stillmark, realizada em fevereiro de 1999, teve como orientação o texto João Fausto, que era o libreto de uma ópera de Hans Eisler, parceiro musical de Brecht, não musicada por ter sido censurada na Alemanha Oriental socialista na década de 1950. Reponho dois exercícios que ele fez conosco sobre o tema: 
- Para estudar o primeiro encontro entre João Salsicha e Grete (personagens da ópera), Alexander propõe que a cena seja improvisada como um número de palhaços. Um ator, como ponto, sopra a fala da personagem. Os atores que improvisam ouvem e reinterpretam a fala à sua maneira. O jogo do escultor: dois atores leem o diálogo de uma cena, preocupados apenas com o sentido de cada fala. Enquanto estão lendo, um ator-escultor movimenta o corpo de dois atores que representam as personagens da cena (MARCIANO, 1999, p. 43).

Os estímulos repassados por Stillmark não se diferenciavam muito de jogos semelhantes aos que aprendemos em alguns cursos de teatro. No entanto, o convívio com o encenador alemão foi útil a ponto de levarmos adiante nossa aproximação a João Fausto, que desembocou em uma leitura cênica, apresentada no Goethe-Institut naquele mesmo ano de 1999, assim como no Centro Cultural São Paulo, por ocasião do primeiro repertório da Companhia do Latão.

Não foi apenas de oficinas, como as aqui relatadas, que fomos compondo o conjunto de conhecimentos que podemos considerar característicos no trabalho dos atores no grupo: a lida sobre os espetáculos e experimentos cênicos entre elencos e direção nos embasaram bem mais do que em outras instâncias (como é perceptível ao longo de todo este documento).

\subsection{AS OBRAS DO PERÍODO INTERMEDIÁRIO}

\section{Auto dos bons tratos (2002)}

Abro o relato sobre a nossa sexta montagem, abordando uma questão que vejo como ética. Depois do sucesso que obtivemos com A comédia do trabalho e também pela minha dedicação aos trabalhos anteriores, estranhei que os diretores estivessem escalando Marcos de Andrade, ator recém-chegado ao grupo, para o papel do Capitão Pero do Campo Tourinho, que seria central em Auto dos bons tratos. Pelo meu raciocínio de então, por eu ter estado na Companhia desde a sua fundação, caberia a mim protagonizar a nova missão da equipe. Fiquei tão intrigado com isso que pedi uma conversa com a dupla da direção e eles tiveram que me repetir preceitos já conversados entre nós. O primordial era o projeto coletivo, mesmo que houvesse uma divisão das funções dentro do conjunto. Tardei em modificar minhas ideias sobre a matéria e acho que ainda hoje elas não se resolveram totalmente, apesar de perceber que houve progressos. Márcio Marciano e Sérgio de Carvalho me disseram que estávamos apenas começando a construção da história da Capitania de Porto Seguro, um tema amplo, e 
que seria melhor se eu empregasse minhas energias colaborando com o entendimento do que viria a ser a obra. Acrescentaram que o personagem a mim reservado, o de um padre francês catequizador dos índios, tinha muitas possibilidades e que seria precipitado discutir se esse ou aquele papel teria ou não mais importância que os outros. À medida que os laboratórios prosseguiram, esqueci aquela pecha diante das alternativas que vinham surgindo no decorrer dos ensaios e das pesquisas, nos quais me cingi para alimentar tanto os meus quanto o todo dos nossos propósitos. Diante da quantidade de tarefas que tínhamos pela frente, preocuparme em ser ou não o protagonista tornou-se dispensável.

Entre os preâmbulos que nos conduziram a investir sobre um quinhão da colonização do Brasil, inicialmente exploramos o contrabando de pessoas e diamantes em Serra Leoa e, em outra borda, nos voltamos para encenar trechos de Anton Tchekhov (Tio Vânia), Henrik Ibsen (Casa de Bonecas) e John Steinbeck (Ratos e Homens). Iniciamos os trabalhos assuntando o tráfico humano e paralelamente visitávamos o realismo como prática atuativa, consequência dos estudos acerca de Stanislavski que antes havíamos feito. Foi assim que entendemos melhor as cenas-modelo, nas quais a direção nos fornecia partes dos clássicos ou variantes e, a partir deles, o elenco recriava situações similares inspiradas nas obras originais. Quero dizer que não só dávamos uma versão cênica àquelas referências como apresentávamos outras situações que vinham dessas fontes, embora com outros enfoques. Essa forma de trabalho, as cenas-modelo, perdurou, tornando-se um dos nossos dispositivos para reinvenções teatrais no grupo.

Achei ótimo ter feito essas cenas de alto nível que também tinham algo de dialéticas. Eram textos de realismo psicológico (no caso de Tchekhov e Ibsen), mas não apenas realistas. Elas possuíam um componente épico, já que os personagens sabiam muito de si mesmos e falavam sobre isso mais do que a média. São textos que vazam o dramático e por isso beiram o narrativo (informação pessoal) ${ }^{43}$.

A atriz Helena Albergaria recordou ainda que Anatol Rosenfeld tinha uma ideia mais clara sobre essa questão: “[...] personagens que vivem no passado saudoso ou no futuro sonhado, mas nunca na atualidade do presente, talvez seja o tema mais épico e menos dramático que existe" (ROSENFELD, 2006, p. 92).

\footnotetext{
${ }^{43}$ Helena Albergaria, em depoimento a Ney Piacentini, em 13 jun. 2016.
} 
O crítico elucida que dentro de dramas realistas, como no caso das obras de Ibsen e Tchekhov, existem componentes narrativos como um excessivo discorrer sobre si mesmo, que expandem a visão sobre os personagens e sobre os contextos em que eles se situam.

Por outra via, Heitor Goldflus resgatou uma terceira natureza de exercícios que praticamos nas preliminares da peça:

Foi proposta pela direção uma improvisação a partir de retratos de jornais, de figuras politicas e a mim coube a de um senador. E eu fiz tudo na contramão. Eu falava uma coisa e fazia outra, ou seja, em um discurso eu proferia "eu amo meu povo" e, ao mesmo tempo, dava uma bronca no técnico do microfone. Algo desse gênero. Uma ação pública demagógica e outra privada reveladora e que criava um problema: como eu iria rosnar com o técnico falando abertamente para uma plateia? De certa forma eu acho que isso inspirou um pouco, mais tarde, que os dramaturgos pensassem o Juiz Escorcyo e, sem dúvida, que eu o realizasse (informação pessoal) ${ }^{44}$.

É de se reparar que Helena e Heitor apontam que atoralmente procurávamos, e nem sempre conseguíamos, dialetizar desde a fase em que ainda não tínhamos escolhido qual seria a fábula nem os personagens que surgiriam mais tarde. E o Juiz Escorcyo, citado por Goldflus, foi o personagem que depois, junto com Padre Bernard e o Capitão Tourinho ${ }^{45}$, representariam os poderes institucionais do início da colonização brasileira, retratada em um dos seus no espetáculo. Como acontecem mudanças de rumos em nossas pesquisas, seja porque determinado caminho não atende às nossas expectativas, seja porque um outro assunto que surja durante o processo se torne mais atraente, migramos para a edificação da Capitania de Porto Seguro. Esse tema estava relacionado com a etapa anterior (de Serra Leoa) pelo comércio de gente - o contrabando humano na África e a escravização dos índios no Brasil e possuía ainda um mesmo recuo temático que versava sobre as origens da mercantilização mundializada. Os ensaios aconteceram no começo da década de 2000 e a globalização, estandarte do neoliberalismo, grassava em todo o planeta como algo positivo, segundo o pensamento hegemônico. De maneira que passamos a problematizar cenicamente o ingresso do Brasil colônia nas trocas capitalistas internacionais, tanto que a frase que viria a fechar a

\footnotetext{
${ }^{44}$ Heitor Goldflus, em depoimento a Ney Piacentini, em 06 abr. 2016.

${ }^{45}$ O elenco contou com: Beto Matos, Cátia Pires, Emerson Rossini, Heitor Goldflus, Helena Albergaria e Ney Piacentini. O ator Gustavo Bayer participou dos ensaios, assim como Marcos Andrade, que esteve concosco até a nossa primeira estreia, do mesmo que Izabel Lima e Fernando Paz atuaram nas temporadas posteriores; direção musical: Walter Garcia; figurinos: Helena Albergaria; assistência de direção e figurinos: Renata Deuse; iluminação: Paulo Heise; cenografia: Antonio Marciano e Márcio Marciano; produção executiva: Ney Piacentini; texto e direção: Sérgio de Carvalho e Márcio Marciano.
} 
peça, mostrando um negociador de cativos trocando os indígenas por negros como um novo produto, era: "Entramos na rota do comércio mundial" (CARVALHO; MARCIANO, 2008, p. 199).

Auto dos bons tratos mostrava os meios de controle do trabalho alheio no início da colonização brasileira, por meio de um processo da Igreja que acusava Pero do Campo Tourinho (donatário de Porto Seguro) de blasfêmia e heresia. De modo que foi inevitável experimentar na sala de trabalho fontes históricas e geográficas. Para estudar a figura central contávamos com a obra da professora carioca Rossana Gomes Britto, que inclusive nos visitou e cujo livro A saga de Pero do Campo Tourinho nos auxiliou. Nessa linha, eu me aproximei de um volume com as cartas de José de Anchieta, por estar conduzindo um padre contemporâneo ao jesuíta e que também tinha como missão converter os índios:

\footnotetext{
$\mathrm{Na}$ catequese mostrou-se incansável: formou um seminário em São Vicente; entrou repetidas vezes no sertão adentro, em visita aos tamoios e carijós, tendo por intérprete os irmãos; com a provisão que Tomé de Souza lhe dera na Baía, restituiu a liberdade aos carijós escravizados pelos portugueses. Enfrentou João Ramalho, a quem certa vez expulsou da Igreja de São Vicente, o que lhe valeu uma tentativa de agressão por parte de um dos filhos do patriarca (ANCHIETA, 1988, p. 60).
}

Se substituirmos São Vicente por Porto Seguro, João Ramalho por Pero de Campo Tourinho e os carijós e tamoios pelos índios da Bahia, poderíamos ver a exegese do meu personagem. Não digo que temos que ser fiéis à história quando fazemos ficção, porém não se pode negar que esses dados que nos ajudam a vislumbrar um papel são bem-vindos.

Olhando para o interior da obra, o meu clérigo tinha lá suas fraquezas. Quando ele surgia na segunda cena da peça, já estava sob o efeito do fumo usado pelos índios, seus educandos. Mesmo não sendo das mais claras as minhas lembranças de como abordamos representar o estado alterado de Bernard de Aurejac, recordo que sua malemolência não era só exterior. Confuso, ele se relacionava com a tribo e com o Juiz Escorcyo (Heitor Goldflus) e o eco das oposições entre as camadas externas e internas do papel se fazia presente. Podemos considerar que, em 2002, estávamos em uma fase intermediária, vinda do realismo nuançado de peças como $O$ nome do sujeito e da cena dialética tecida em A comédia do trabalho, em direção à atuação contraditória que viria a se desenvolver ainda mais dali em diante. Transição truncada em mim, uma vez que, em virtude da falta de uma consciência maior, predominava em meu pároco o seu estado intoxicado e não a sua dificuldade em se mostrar normal. 
Por outro ângulo, ficou-me gravado um ensaio, que creio ter acontecido em um domingo pela manhã, quando estávamos improvisando algumas cenas pré-desenhadas da futura peça. Nele, trabalhávamos sobre o processo de inquirição em que Bernard pressionava João Douteiro, o ferreiro local (interpretado por Emerson Rossini), a admitir suas aberrações junto aos índios, a mando de Tourinho, o donatário. O juiz procurava segurar o descontrole do meu padre que estava tomado por ditames bíblicos, invocando bestas e espadas. Ao ser reprimido pela sua embriaguez: "Eu lhe proibi de beber hoje", dizia-lhe Escorcyo em voz baixa, meu personagem lhe respondia: "Eu bebo sim" (CARVALHO; MARCIANO, 2008, p. 174), acrescentando que, para que tolerar as crueldades contra os índios, "só mesmo se embebedando" e frases semelhantes. Essa reviravolta não estava prevista e eu mesmo me surpreendi com uma ação contrária ao senso comum: normalmente, quem bebe não o assume abertamente e, assim, aquilo tanto escapou vivamente que foi utilizado na dramaturgia final, com o posterior tratamento literário. Intuitivamente ou não, revelou-se nesse caso uma atitude atoral reversa.

Igualmente, é sabido que, depois de encontrado um embrião genuíno, nós, atores, não costumamos refazer o percurso que levou à descoberta, mas nos precipitamos ao ápice do acontecimento cênico, como se já estivéssemos no auge da cena desde o seu início. Não absolutamente, mas foi o que ocorreu comigo por um tempo com a indignação do padre, até que a direção me reorientasse para que eu tivesse a noção do acúmulo gradativo de uma ira que seria a resultante de sucessivas adversidades.

Em seu desfecho, meu religioso terminaria por se imiscuir entre os índios, dançando com eles um canto tribal. Ao não aceitar aquela mixórdia, o Juiz ouvia de Bernard: "Está tudo bem, nunca esteve tão bem. Temos que ser um pouco como eles" (CARVALHO; MARCIANO, 2008, p. 193). Como se pode constatar, meu catequizador propunha um meio mais brando de dominação, menos brutal do que o do colonizador Pero do Campo ${ }^{46}$ que, na peça, afinal, é embarcado para Portugal, onde seria julgado pela Inquisição de Lisboa por confrontar a Igreja.

\footnotetext{
${ }^{46}$ Raízes do Brasil, o livro de Sérgio Buarque de Holanda, norteou-nos a respeito dos modos de dominação no Brasil, especialmente em seu capítulo "O homem cordial”, não só em Auto dos bons tratos, como também em $O$ nome do sujeito e em $O$ patrão cordial.
} 


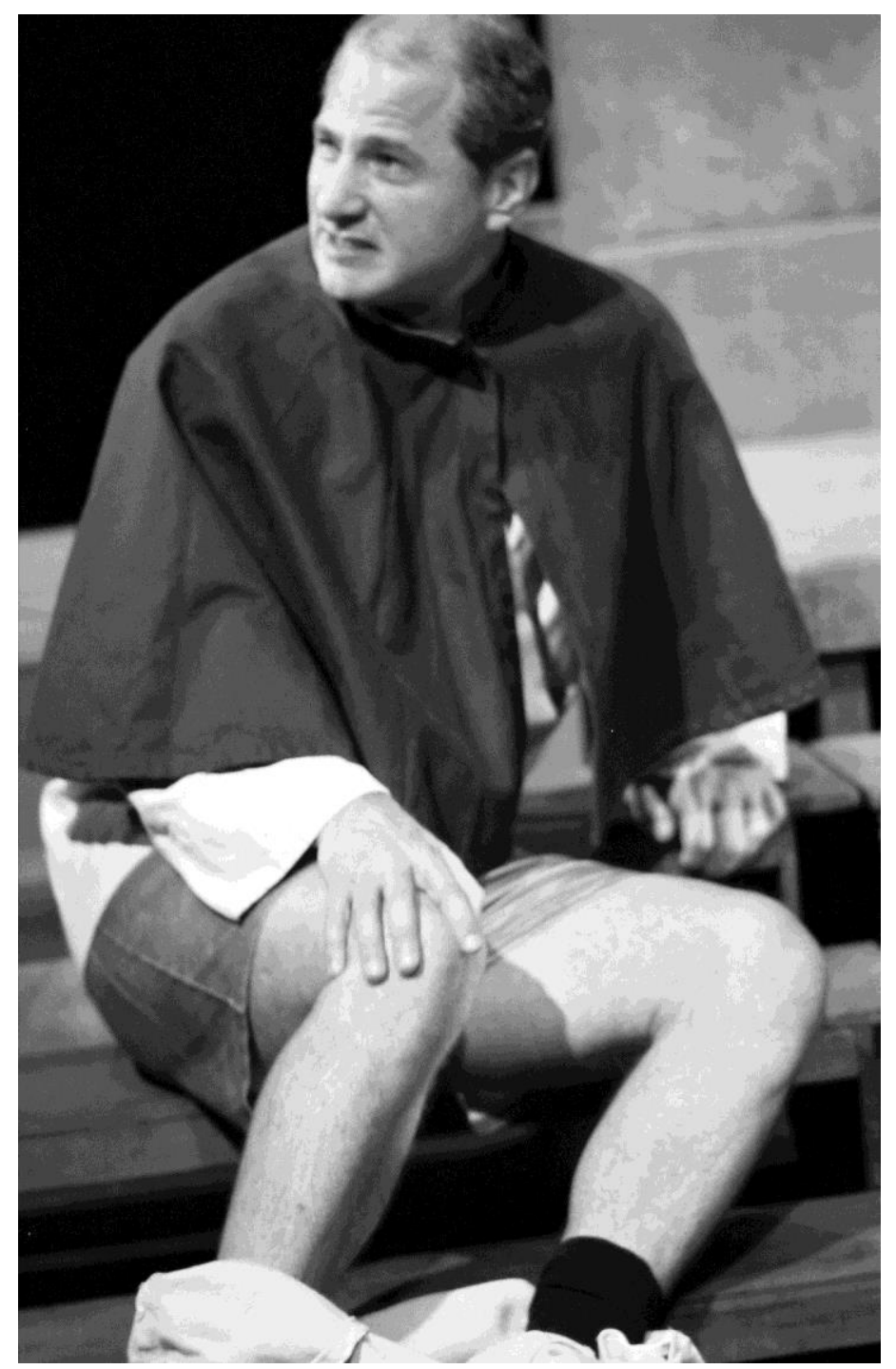

Ney Piacentini (Padre Bernard de Aurejac). Auto dos bons tratos, 2002. Foto: Lenise Pinheiro.

Ainda nessa obra, ao lado de Emerson Rossini, envolvemo-nos com a dupla Biela e Manivela: "Eles vieram de uma improvisação em que fazíamos dois pescadores que reproduziam a relação de classes, em uma cena clownesca em que um domina o outro pelo raciocínio pseudológico, e que depois viravam dois empregados do Capitão" (informação pessoal $)^{47}$. Acrescento à lembrança do meu parceiro que também nos servimos dos coveiros de Hamlet, particularmente quando eles jogam com as palavras:

PRIMEIRO COVEIRO: Com licença. Aqui está a água; bem. Aqui está o homem; bem. Se o homem vai para a água e se afoga, é ele, quer o queira, quer não, que vai até lá. Toma nota. Mas se a água vem para ele e o afoga, não é ele que se afoga. Logo, quem não é o culpado de sua própria morte, não encurta a vida (SHAKESPEARE, n/d, p. 96).

\footnotetext{
${ }^{47}$ Emerson Rossini, em depoimento a Ney Piacentini, em 12 jul. 2014.
} 
Similar à resposta que dávamos ao nosso patrão - Capitão Tourinho, ao voltarmos de uma caçada a um escravo: "O fugitivo se recusou a colaborar e se atirou contra as pedras que trazíamos nas mãos”. "A mão de obra não quer continuar viva" (MARCIANO; COELHO, 2008, p. 158). Eram tipos que ficavam entre a estupidez e a esperteza, rudes e de uma perspicácia inútil.

De participação mais breve foi Gregório, vigia do Capitão Tourinho na prisão. A parte em que esse simples homem aparecia servia de elo para o principal na cena, que era a visão que seu superior tinha de Santa Luzia (Helena Albergaria) a qual, por sua vez, dava-lhe uma lição de cordialidade no lugar de suas violências. Restringindo-me ao aldeão, fazia-o com certo carinho, apesar de ele professar uma crença pessoalmente duvidosa para mim. Gregório, do lado de fora da cela, dizia ao Capitão que se ele não tivesse jogado a Santa "de um penhasco", agora poderia ver a procissão com a estátua reconstituída, e “[...] as túnicas brancas, as crianças com estrelas nas mãos". Frente à rispidez de Pero de Campo, que bradava: "Nenhum Santo Antônio ergueu a igreja, nenhum São Martinho cortou os índios na espada. Foi o meu trabalho. Está ouvindo? O meu trabalho", meu vigia reagia dizendo que seus pais o ensinaram "[...] a respeitar os céus, porque homens como o senhor faziam parte do firmamento". E não acreditava que "tudo são ações dos homens e não é fixo o meu lugar na ordem do mundo" (CARVALHO; MARCIANO, 2008, p. 183-184).

Sua educação católica ponderava os ataques verbais de Tourinho, o que me conduzia à ingenuidade do colono. O crédito dessa junção de crença e elaboração literária deve ser atribuído aos dramaturgos-diretores, sem dúvida, que me levaram a usufruir de um tom poético, ainda que ele expressasse ideias conservadoras.

Contudo, abrindo o campo do trabalho dos atores para Auto dos bons tratos como parte de um projeto maior da Companhia do Latão, fiquemos com o seguinte comentário crítico:

\footnotetext{
Esse teatro, que assume sem medo sua função pedagógica, torna-se radical não pelo emprego de tecnologias de ponta ou pela qualidade subterrânea e contraventora da pesquisa, mas por dar as costas a recursos teatrais, concentrando-se na discussão das ideias, na exposição racional e bem elaborada dos temas em questão (GUZIK, 2002, p. D5).
}

O mercado do gozo (2003)

Este projeto derivou de uma pesquisa inicialmente chamada Mídia e Poder, em que estávamos nos propondo a conhecer um pouco mais sobre as relações entre a imprensa e o 
poder econômico e político no Brasil. Começamos com improvisações sobre o ambiente de um grande órgão de comunicação do país, fazendo cenas que envolvessem um dono de jornal e as possíveis conexões com os governos e empresários. Todavia, mudamos de rota após um ciclo de palestras que contou com a participação de Mino Carta, Tereza Cruvinel, Raimundo Pereira, Eugênio Bucci, Fernando Haddad, Fernando Rodrigues de Souza, Nelson de Sá, Marcelo Coelho e Marco Antônio Araújo. A partir da abordagem sobre a fabricação do imaginário e a compra do olhar, presentes na palestra de Eugênio Bucci, deslocamos o objeto:

O olhar social é comprado para compor a imagem da mercadoria. É o capitalismo em outro patamar. Isto eu também não digo sozinho porque Guy Debord já disse isso quando afirmou: o espetáculo é o capital num tal grau de acumulação que se torna imagem. Só isso explica por que o negócio da mídia se tornou um dos negócios do capitalismo contemporâneo... (BUCCI, 2004, p. 22).

De maneira que o nosso interesse se voltou para o "início da hegemonia estética das mercadorias [...] em que a forma da narrativa é também uma personagem desconfiável"48.

O projeto envolveu cerca de cinquenta pessoas e contou com oficinas, encontros e debates, nos quais também recebemos Margareth Rago, Roberto Schwarz, Maria Rita Kehl e Iná Camargo Costa, a partir de quem incluímos os temas da prostituição e da influência da televisão na formação do brasileiro. Para os ensaios, a nossa equipe se dividiu em quatro linhas de investigações: uma de teatro de rua, outra de realismo, uma terceira de cinema e vídeo e uma última de música. Cada atriz/ator se engajou em uma dessas frentes, ficando responsável por levantar dados e propor à equipe exercícios e situações. Eu me engajei nos exercícios fílmicos e, desconsideradas algumas experiências que coordenei, o que vingou foi um simples mecanismo utilizado para reproduzir uma projeção de cinema: um lençol foi esticado e, por trás dele, uma lâmpada comum com um ventilador à sua frente enquadravam as atrizes fazendo uma pantomima de posições sexuais. $\mathrm{O}$ efeito era como o de um filme mudo em seus primórdios, com as imagens trêmulas e imperfeitas. Este foi um dos casos em que os atores pensaram, produziram e realizaram a ideia com a posterior adesão dos diretores à proposta, que posteriormente foi adaptada ao contexto da peça.

De modo que escolhemos fazer da presença do cinema na obra algo indireto e sugerido. Como quando parávamos as ações e olhávamos para um ponto fora do espaço

\footnotetext{
48 Site da Companhia do Latão. Na página Espetáculos, sobre O mercado do gozo. Disponível em: <www.companhiadolatao.com.br>. Acesso em: 13 maio 2016.
} 
cênico, como se houvesse alguém dando instruções para que a tomada fosse refeita com mudanças. Ou em outro segmento no qual dois atores trocavam de posição em uma cena: na primeira versão, um homem era bruto com uma mulher (uma operária em vias de se prostituir) antes do ato sexual entre os dois em cima de uma campa em um cemitério. Na segunda versão, feita logo após a primeira, a mulher é que abordava o homem ainda vacilante se iria ou não consumar o programa. Esse quadro era revelador não apenas formalmente, mas possibilitava a reversão do ponto de vista de uma cena através da alteração da postura dos personagens diante do problema.

Sobre o enredo da peça, O mercado do gozo seguia os passos de um industrial (Burgó - Emerson Rossini) que se imiscuía no submundo da prostituição e das drogas, enquanto na cidade de São Paulo aconteciam as greves de 1917. Tínhamos a meretriz Rosa Bebé (Helena Albergaria) e, ligadas a ela, as prostitutas Cafifa e Getúlia (Izabel Lima e Victória Camargo). O dono de um opiário - Papoula (Beto Matos) - e o cafetão Bubu (Ney Piacentini), entre outros papéis $^{49}$. Some-se a isso um terceiro viés dramatúrgico, oriundo das prévias investidas imagéticas e que se traduziu em um filme sendo rodado durante a história, interrompendo as ilusões vividas pelos personagens. Na peça "O espectador é conduzido por um caminho que suspende as fronteiras espaciais que separam a fábrica do bordel, o operário da prostituta e, por fim, o dono da fábrica do cafetão" (FONSECA, 2003, p. 11).

E cuja matéria foi esmiuçada por um de seus criadores:

“A mercadoria opera muito por produção do desejo. Ela se mantém em aberto, à espera de uma satisfação abstrata, promessa de valor de uso, do gozo a cada relação. Daí a erotização do mundo mercantil, presente também na indústria cultural” (CARVALHO, 2003, p. 5-1).

Redirecionando o debate para a ótica dos atores, Beto Matos nos refez o percurso que o levou ao seu travesti Papoula, proprietário de uma casa de ópio:

Eu comecei experimentando fazer um anão que a Helena tinha achado em um dos livros da pesquisa, o Joãozinho. Ele seduzia as prostitutas com contos infantis em versão

\footnotetext{
49 Atores: Beto Matos (depois Fernando Paz), Emerson Rossini, Helena Albergaria, Izabel Lima, Ney Piacentini e Victória Camargo; direção musical: Martin Eikmeier e Walter Garcia; figurinos: Márcio Medina; assistência de figurinos: Helena Albergaria; assistência de direção: Renata Deuse; iluminação: Paulo Heise; cenografia: Antonio Marciano e Márcio Marciano; pesquisa cinematográfica: Diogo Noventa, Marco Dutra, Caetano Gotardo e Juliana Rojas; assistência de pesquisa: Douglas Estevan e Rafael Carvalho; preparação corporal: Vivien Buckup; produção: Ney Piacentini; texto: Sérgio de Carvalho, Márcio Marciano e Helena Albergaria; colaboradores: Ney Piacentini, Emerson Rossini, Beto Matos, Izabel Lima e Victória Camargo; direção: Sérgio de Carvalho e Márcio Marciano.
} 
pornográfica. Era um boca-suja e fazia as mulheres costurarem as meias dele. Fizemos uma cena com esse anão apresentando um show em um cabaré e contando essas histórias erotizadas para crianças, mas foi um tipo que não vingou. Já o Papoula, que eu fiz na peça, ele oferecia drogas para os clientes, mas se condoía com os problemas alheios. Eu parti da indicação de uma figura com certa afetação, acentuada, mas não caricatural. Perguntava-me onde estaria aquela feminilidade em mim e até que ponto eu externalizaria isso sem cair no estereótipo. E formalmente eu fazia uma voz característica, trejeitos com os braços e mãos e me apoiava numa única perna o que me dava um pouco de delicadeza (informação pessoal $)^{50}$.

Nas palavras de meu colega, reconhecemos a preocupação em não deixar que o papel se tornasse unilateral. $\mathrm{O}$ travesti de Matos era um contraventor, um repassador de ópio, porém acolhia afetivamente quem frequentava sua casa noturna. Era afeminado, mas o ator e os diretores cuidaram para que houvesse um equilíbrio entre o masculino e o feminino no personagem, evitando o clichê.

Já a relação do meu proxeneta com suas fêmeas era de puro negócio e parte do seu vocabulário sobre elas vinha de contas e cálculos: "Fizemos um acordo, você não deprecia as minhas mercadorias, eu não deprecio as suas" (CARVALHO; MARCIANO, 2008, p. 213) dizia reclamando a Papoula sobre o consumo de drogas de uma de suas meninas; "Uma boa embalagem eleva o valor de qualquer produto. É uma sábia lei da economia" (CARVALHO; MARCIANO, 2008, p. 227) - ao dar de presente um chapéu a uma operária a quem queria seduzir; "Faz três dias que te procuro peso falso" (CARVALHO; MARCIANO, 2008, p. 254). Este último termo, por exemplo, que se refere a uma prostituta menor de idade, foi retirado de um livro sobre a prostituição de mulheres judias na Argentina, El camino a Buenos Aires ${ }^{51}$.

Note-se que estamos falando da troca entre o elenco e a dramaturgia/direção, na medida em que levávamos sugestões às cenas, como a terminologia do caftén contida no livro de Albin Michel, as quais, quando coubessem, seriam inseridas no corpo do texto em criação.

Outra leitura que nos guiou, trazida por Helena Albergaria, foi Boca do Lixo, autobiografia de Hiroito de Moraes Joanito ${ }^{52}$, um criminoso que se envolveu com drogas e prostituição e ganhou fama em São Paulo na década de 1950. Dessa fonte veio também a raiz

\footnotetext{
${ }^{50}$ Beto Matos, em depoimento a Ney Piacentini, em 29 maio 2017.

${ }^{51}$ MICHEL, Albin. El camino a Buenos Aires. Tradução do francês para o espanhol de Albert Londres. Buenos Aires: Prensa Ibérica, 1967.

52 Boca do Lixo. São Paulo: Labortexto, 2003.
} 
do que depois se tornaria a personagem de Albergaria, uma meretriz que teve seu rosto queimado pelas amigas por ter roubado os clientes delas.

Para a evolução do papel, entre outros fatores, a atriz entrevistou profissionais do ramo, entre as quais uma mulher que, quando virara cafetina, obrigava suas mulheres a fazerem tudo o que ela odiava quando estava na ativa, como ter relações menstruada, com febre ou amamentando. Essa figura real reconhecia que explorava quem com ela trabalhava e afirmava que, por mais precária que fosse a condição de quem entrasse na prostituição, isso era sempre uma opção que envolvia algum prazer. "Inverte a nossa lógica de classe média de achar que elas são só umas coitadas e isso foi criando ruídos para o meu papel” (informação pessoal) $)^{53}$, comentou Helena.

De modo que, filtrando as informações e sugestões que trazíamos, os dramaturgos Sérgio de Carvalho e Márcio Marciano deram vida aos papéis, servindo-se de sentenças como:

BUBU: Rosette Bebé, minha máquina mais azeitada, mantém positivo o balancete. Mas o senhor não imagina o quanto custa repor o desgaste da utilização. Quanto as minhas outras peças menores, as desgarradas, contabilizo como quebra de estoque, faz parte do negócio. Essa profissão não é ofício para um pai de família (CARVALHO, MARCIANO, 2008, p. 236).

Sobre a minha atuação dialética, temos que levar em conta o fato de que meu cafetão era ao mesmo tempo cruel e sentimental. Os contrates desse comerciante de gente chegariam ao ápice quando da fuga de sua querida Rosa Bebé para Buenos Aires. Voltando da Argentina, ele contava a Papoula como a tratou depois de resgatar a sua presa:

BUBU: Trouxe-a de volta comigo

amarrada no porão do navio

para que não ouvisse seus pedidos.

Minha cabeça embranqueceu em três dias.

Chegamos em Santos

subimos a serra num carro alugado

Ela compreendeu que era melhor voltar calada.

Parei, mandei-a descer

Ela disse que era só minha

Dei-lhe um murro

\footnotetext{
${ }^{53}$ Helena Albergaria, em depoimento a Ney Piacentini, em 13 jun. 2016.
} 
Joguei gasolina na sua cara.

Acendi o fósforo.

Meu maior título de renda feito cinza (CARVALHO; MARCIANO, 2008, p. 256).

Tênue era o tom da violência, quase como um poema de amor. A ponto de, nessa confissão, meu personagem se desfazer de seus bem cortados terno e colete, desabrindo a camisa para mostrar uma tatuagem de Rosa no centro do peito, maior que a de outras mulheres nos lados:

BUBU: Foi uma homenagem. Dei a ela um lugar que não daria à minha mãe. Fiz na primeira semana em que nos conhecemos. Por ela ter se deitado 132 vezes em sete dias. Uma produtividade incrível. Por 132 vezes ela desfez os laços das sandálias. Acredita? Eu estava apaixonado (CARVALHO; MARCIANO, 2008, p. 256).

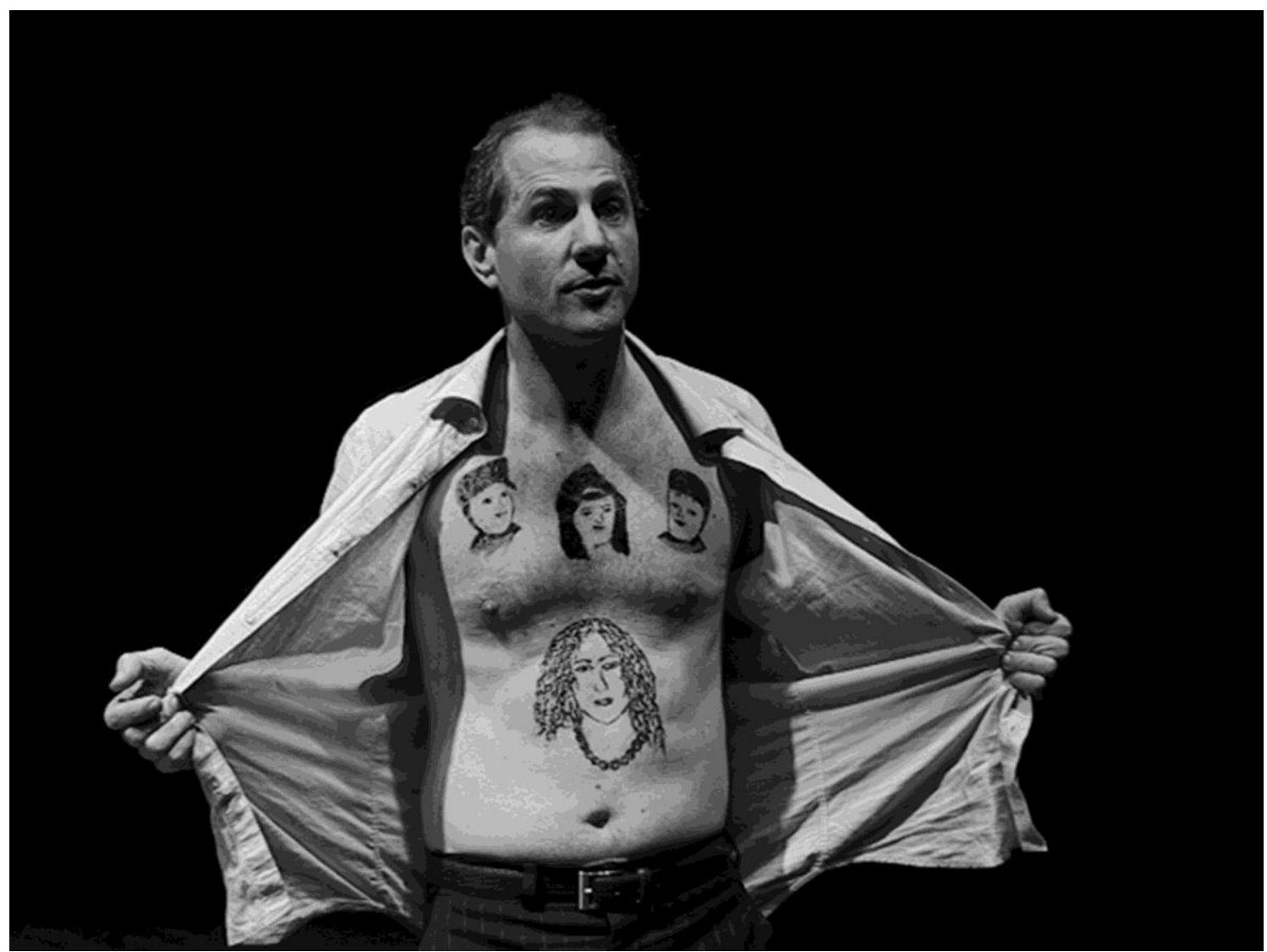

Ney Piacentini (Bubu, o cafetão). O mercado do gozo, 2003. Foto: Lenise Pinheiro.

Emocionado, o mercador de mulheres era consolado por Papoula, que lhe oferecia um cachimbo de ópio e, chorando, ele ainda reclamaria da "ganância" de sua prenda, por querer ter seu próprio negócio, desprendendo-se dos cuidados que ele lhe reservava. No entanto, meu 
cafetão não a matara, apenas queimara seu rosto. Portanto, "Nunca mais ela será Rosette La Rubra, agora é Maria, a Calabresa" (CARVALHO; MARCIANO, 2008, p. 257).

Depois da canção em que Rosa surgia com a face desfeita, o cáften, refeito de sua desolação, dizia que iria optar por um comércio limpo:

BUBU: Papoula, eu preciso de um capital sólido, livre das flutuações do mercado. A burguesia do crime trabalha de mãos limpas.

PAPOULA: É a parte que eu não gosto: a ascensão social sempre requer violência.

BUBU: Não vou mais lidar com gente, melhor usar as mulheres aos pedaços, fazer retratos, calendários, películas para o cinematógrafo. Negócio sem gente é mais sossegado (CARVALHO; MARCIANO, 2008, p. 258).

E Bubu abraçava Papoula dizendo que só tinha a ele e a alguns amigos na polícia, com desolação. Nesse caso, o estranhamento não vinha só do aparente domínio de seu linguajar empresarial para tratar de relações informais com a prostituição. Ao escaparmos da vilania comum em cafetões no teatro, introduzindo traços melancólicos em suas agressões, chegamos a distintas contraposições. Esse negociante de fêmeas não apenas se apaixonara por sua refém, como sofria feito um amante desiludido e era nessa condição de rejeitado que ele, afetivamente, descrevia de que modo ateara fogo no rosto de seu "exemplo de trabalhadora" (CARVALHO; MARCIANO, 2008, p. 236).

Creio que, nessa obra, demos um passo a mais em direção à contradição nas interpretações. Os personagens se desvendavam estranhos pelas suas incongruências íntimas. A ironia existia não pelo recuo dos atores em seus papéis, mas sim pela identificação com os mesmos. Como se transbordassem exacerbados conflitos internos para quem os visse de fora, mas não para os personagens. $\mathrm{O}$ que quero com isto sugerir é que demos continuidade a nos envolvermos ainda mais no propósito praticado em Auto dos bons tratos, em uma representação capaz de provocar a desconfiança do espectador por suas cargas dramáticas e emotivas, além das narrativas. E seria preciso adicionar a forma da peça que, por suas interrupções do correr dramático, conosco parando as cenas e as repetindo de outro modo para um suposto e invisível diretor de um filme, reforçava a desconfiança do público.

No começo do processo de $O$ mercado do gozo, junto aos alunos das oficinas que envolviam o projeto, fizemos algumas experiências improvisadas em que teríamos, em fragmentos dramáticos (sem a quebra das cenas com narrações ou canções, entre outros meios que conhecíamos de distanciamento), de modo a extravasar sofrimentos desmedidos dos personagens em situações que a princípio não os levariam a tais exageros. Em algumas 
ocasiões, isso simplesmente fracassava, embora em outras algum proveito guardássemos desse distanciamento interiorizado. Não foi à toa que, ao final do processo da pesquisa, as marcas dessa estranheza de um papel com ele mesmo, em alguma medida, estiveram presentes nos papéis da obra.

O espetáculo acabava fora do teatro, tendo um automóvel de época como cenário, em uma tomada externa noturna de uma filmagem, justo na cena em que Bubu incendiava Rosa, promovendo, como o todo da obra, uma intersecção de planos narrativos, como apontou a crítica Mariângela Alves de Lima:

"Nos três planos ficcionais que estruturam a peça figuram o movimento operário, acontecimentos que se desenvolvem no universo da prostituição e a feitura de um filme que contém a um só tempo o universo do bordel e da produção fabril” (LIMA, 2003, p. D5).

As discussões sobre a dramaturgia e a encenação de $O$ mercado do gozo mereceriam mais espaço, no entanto, como venho centrando minha atenção em pontos sobre a interpretação, adianto-me na cronologia dos espetáculos realizados pela Companhia do Latão.

\section{Equívocos colecionados (2004)}

Iniciamos as investigações para o que viria a ser a oitava peça do grupo com a leitura de entrevistas dadas por Heiner Müller. O teórico Hans Thies Lehmann viria da Europa nos ministrar uma oficina sobre o dramaturgo alemão e solicitou que lêssemos textos nos quais Müller comenta uma série de assuntos e problemas sobre a Alemanha Oriental. Inéditos no Brasil, Christine Röhrig os traduziu para que estudássemos esse material, aguardando a chegada de Lehmann. Em Necrofilia é amor ao futuro havia, principalmente, uma crítica à classe média, incapaz de transformações. Em Para sempre em Hollywood, a morte aparecia como tema e em Quero ver Brecht no peep-show, se discutia basicamente a importância do prazer. Não lineares, as respostas de Müller a Franz M. Raddatz (em Necrofilia é amor ao futuro e Para sempre em Hollywood) e a Wolfgang Heise (em Quero ver Brecht no peepshow) nos foram arremetidas por Hans T. Lehmann, cujo intuito foi demonstrar ser Heiner Müller um pensador progressista. "Num tempo em que a tradição socialista internacionalmente é mais e mais diluída por todos os lados, e no Brasil ela nunca foi uma práxis, incomoda a atitude fraturada de Müller” (MARCIANO, 2004, p. 48). Apesar da ponderação de um dos nossos diretores à época, fomos conferir o que o propositor do teatro pós-dramático tinha a nos dizer.

E Lehmann entregou o que prometeu. Vamos acompanhar algumas de suas considerações, lançadas naquela sua oficina conosco: 
A forma de trabalhar de Heiner Müller é procurar na história e na política momentos em que houve a destruição. E apontar para ela não dando uma resposta, mas de uma maneira tão forte que se induza o leitor ou o espectador a uma reação que necessariamente teria de levar a uma revolta (LEHMANN, 2004, p. 45).

É uma resistência contra a cultura capitalista que só conhece o presente, para quem só existe o tempo presente. E sua perspectiva é a da relação com a grande História coletiva. Nisso ele está de acordo com a crítica marxista da sociedade burguesa: com o burguês surge o medo da morte. Essas imagens da paisagem histórica em Müller sempre são imagens de uma convivência de uma vida coletiva. A tarefa do teatro é a de que olhemos além da própria vida, no sentido de que nos entendamos como elemento da história da humanidade (LEHMANN, 2004, p. 46).

Nós poderíamos, então, concluir que a voz que nós ouvimos nessa peça (Hamlet-Máquina) é a do resto, daqueles que ficam à margem da sociedade, a expressão daqueles que normalmente não têm voz, os marginais, os criminosos (LEHMANN, 2004, p. 46).

Ela (a voz de Müller) nos faz lembrar sem cessar - aos atores, diretores, e também ao público - que nós temos a necessidade e o dever de estarmos constantemente inventando e reinventando o teatro (LEHMANN, 2004, p. 45).

A partir destes e de muitos outros aspectos que foram discutidos durante uma semana por Hans Thies Lehmann e a equipe do Latão, meses depois iniciamos os trabalhos cênicos a respeito de partes dos Equívocos reunidos, que reunia entrevistas, colóquios, comentários e anedotas de Heiner Müller, como:

Wagner-Régeny contou uma piada a Brecht. Uma velha virgem estava tendo a sua primeira relação sexual e falou ao seu galã: "Meu jovem, afinal, está querendo sair ou entrar? Esse eterno vai e vem está me dando nos nervos". Wagner-Régeny esperava que Brecht caísse na gargalhada. Mas ele ficou calado, pensando por um longo tempo, e depois disse: "O pequeno-burguês só suporta a situação, o estado: ele odeia a mudança”. O problema é exatamente este (MÜLLER, 2004, p. 26).

Na edição de janeiro de 1933 da revista Die Rundschau, surgiu um artigo de Malaparte com o título: "Lênin, pequeno-burguês". Nele, o autor descreve Lênin em seu habitus, seu estilo de pensamento, seu modo de vida como típico pequeno-burguês. O texto termina com a frase: "O pequeno-burguês ainda vai nos dar muito trabalho, nesse século". O dilema deste século é certamente a corrupção do movimento revolucionário na Europa, pelos pequenoburgueses (MÜLLER, 2004, p. 27). 
Quando conduzimos a utopia do comunismo de volta ao seu cerne religioso, ela é uma crença na imortalidade. Em 1871, os participantes da Comuna de Paris atiraram nos relógios. Era esse o impulso revolucionário: deter o tempo, e dentro disso está o desejo da imortalidade (MÜLLER, 2004, p. 31).

Quem for idêntico a si próprio, este pode ser colocado no caixão, este já não existe mais, não está mais em movimento. Idêntico é um memorial. O que precisamos é do futuro, e não da eternidade do instante. Precisamos desenterrar os mortos, mais e mais, porque só deles podemos receber o futuro (MÜLLER, 2004, p. 35).

Eis alguns dos estímulos que recebemos, sendo que este último, sobre a morte, fez com que Hans Thies Lehmann nos endereçasse a pergunta: "E quem são os mortos da cultura brasileira?". Assim, resumidamente, Equívocos colecionados "Foi a primeira experiência da Companhia do Latão com o estilhaçamento da fábula, num trabalho de choque entre fragmentos líricos e históricos”. E “O tema da 'cultura como diálogo com os mortos' é trabalhado na perspectiva da deterioração atual do ideário nacional-popular, tal como formulado no Brasil da década de 1960 em obras como Terra em transe de Glauber Rocha"54.

Como não poderia deixar de ser, as atuações eram distintas das peças anteriores, uma vez que não tínhamos personagens propriamente, mas espectros deles. Um juiz dos mortos e sua assistente viam desfilar uma ex-estudante politizada transformada numa consumista. Um ex-intelectual que migra para a publicidade, uma prostituta que foi uma cantora popular e um técnico da construção civil, ex-líder. Completavam o painel um Hamlet-pianista, um Faustoiluminador e os Mortos. Para tanto, representávamos a seco, sem nos preocuparmos com os antecedentes dos papéis, se tinham tido essa ou aquela trajetória, uma vez que eram figuras cadáveres, como se não houvesse nada por trás deles. As rubricas do texto da peça indicavam como agiam os atores:

Música. Sentados lado a lado nas cadeiras de uma pequena plateia superior, quatro personagens olham para o vazio. Com o início da música, procuram comunicar-se através de rictus e posturas corporais grotescas, transmitidas de um para outro. São eles os réus defuntos que aguardam julgamento... (CARVALHO; MARCIANO, 2008, p. 380).

\footnotetext{
54 Companhia do Latão. Na página Espetáculos, sobre Equívocos colecionados. Disponível em:
} <www.companhiadolatao.com.br>. Acesso em: 21 jun. 2016. 
Os réus descem da plateia superior e posicionam-se ao lado do piano. O juiz ordena com um gesto de bengala que se acomodem sob a cauda do instrumento. Agem como mortosvivos, como se as juntas estivessem petrificadas. Assustadiços. Abrigam-se, por fim, debaixo do piano (CARVALHO; MARCIANO, 2008, p. 381).

Eu tinha uma referência para fazer o juiz em Equívocos colecionados que era $O$ Julgamento de Lúculus de Brecht, como uma imagem para o meu papel também de julgador na peça. $\mathrm{E}$ a caracterização exterior dada pelo figurino, chapéu, paletó, bermudas vermelhas, coturno e bengala, sustentava minha figura em cena (informação pessoal) ${ }^{55}$.

Como se pode reparar, as palavras de Heitor Goldflus ${ }^{56}$ se reportam às imagens que desenhavam seu personagem e não os conteúdos recorrentes para a criação de um papel. Embora tivesse acontecido um momento-chave nos ensaios que fez com que capturássemos a atmosfera de Equívocos colecionados. Quem nos narra é Marina Henrique, que foi assistente de direção nesse trabalho:

Numa das tardes de ensaios, aproximando-se a estreia, os atores manifestaram suas
angústias e questões em relação à construção de cenas caricatas e a falta de uma base
dramatúrgica para seguirmos, pois, afinal, as cenas eram compostas a partir de textos
teóricos e não dramáticos ou literários. Fui para casa sem saber como sanar a crise dos
atores através de propostas de aquecimento. Também parecia ter cessado, desgastado, o
modo que estávamos trabalhando, no entanto, eu queria fazer algo, propor e não sabia por
onde começar. Nada como levar para o sono as perguntas. No dia seguinte, acordei com
uma ideia maluca. Cheguei um pouco antes e combinei com Martin Eikmeier, músico da
companhia, que quando todos chegassem eu iria começar a falar algumas coisas e ele
deveria tocar o piano enquanto eu falasse. O clima de início de ensaio estava descontraído,
as pessoas iam chegando e batendo papo na sala, alguns atores se alongavam no palco e Martin estava ao piano. Emerson Rossini estava do lado de fora e Ney Piacentini, nesse dia, chegaria um pouco mais tarde. Chamei o grupo para uma conversa, fingi estar em crise também, imitava, não explicitamente, a tarde anterior. Martin tocava e improvisava conforme o que eu ia falando. Chamei uma das atrizes para se colocar em meu lugar no palco. Os diretores pediram para que o piano parasse, afinal, parecia grosseria. Algum ator riu da minha crise e a partir disso, desse momento, desse clima, fomos improvisando uma

\footnotetext{
${ }_{55}^{55}$ Heitor Goldflus, em depoimento a Ney Piacentini, em 06 abr. 2016.

56 Elenco: Emerson Rossini, Heitor Goldflus, Helena Albergaria, Izabel Lima, Marina Henrique (depois Alessandra Fernandez) e Ney Piacentini; direção musical: Martin Eikmeier; figurinos: Helena Albergaria; iluminação: Paulo Heise; assistência de direção: Marina Henrique; texto: Márcio Marciano, Sérgio de Carvalho, Marina Henrique e Helena Albergaria, a partir das entrevistas de Heiner Müller e do filme Terra em transe, de Glauber Rocha; colaboradores: Ney Piacentini, Emerson Rossini, Heitor Goldflus, Izabel Lima; direção: Sérgio de Carvalho e Márcio Marciano.
} 
cena desconstruída. Todos entraram na proposta e os atrasados adentraram uma cena bagunçada, cheia de fragmentos de personagens e em uma situação de crise. Ficamos um tempo longo improvisando. Os diretores cessaram a cena depois de mais de uma hora, quando a proposta já se esgarçava. Fomos tomar um café felizes, pois algo de interessante havia acontecido. Ao voltarmos, nos foi pedido que remontássemos a cena, porém, com consciência do processo. A partir desse momento, descobrimos a forma da cena e a dramaturgia amadureceu o desmembramento da fábula. O processo deslanchou e acabei trabalhando também como atriz neste trabalho (informação pessoal) ${ }^{57}$.

Essa improvisação foi crucial na definição da atmosfera em que as figuras cênicas se movimentariam. Uma espécie de instabilidade permanente que, se aliada ao fato de eles estarem mortos, causaria uma impossibilidade de absolvição, o que os levaria à exasperação. Isso também forneceria os contornos da interpretação: sem arrefecimentos ou introspecções. Visto que quando o projeto se mesclou aos excertos de Terra em transe, longa-metragem de Glauber Rocha, as atuações já estavam rascunhadas. O que significava que a interpretação acalorada do elenco se alinhou ao modo representacional inconformado de um dos principais filmes do cinema novo brasileiro. Porém não se buscava um estilo e sim desdobrarmos aquelas personas que clamavam por julgamento, cientes de suas responsabilidades perante a história. Havia uma pressão sobre elas, externa e interna, e tal clausura as fazia nervosas.

Equívocos colecionados não se filiou a nenhum outro dos nossos trabalhos, caracterizando-se por uma dramaturgia interceptada e febris interpretações. Todavia, isso tudo não deixou de adotar um predicado constante da Companhia: todos os recursos técnicos e formais a serviço das razões da obra.

\footnotetext{
${ }^{57}$ Marina Henrique, em depoimento a Ney Piacentini, em 19 jun. 2016.
} 


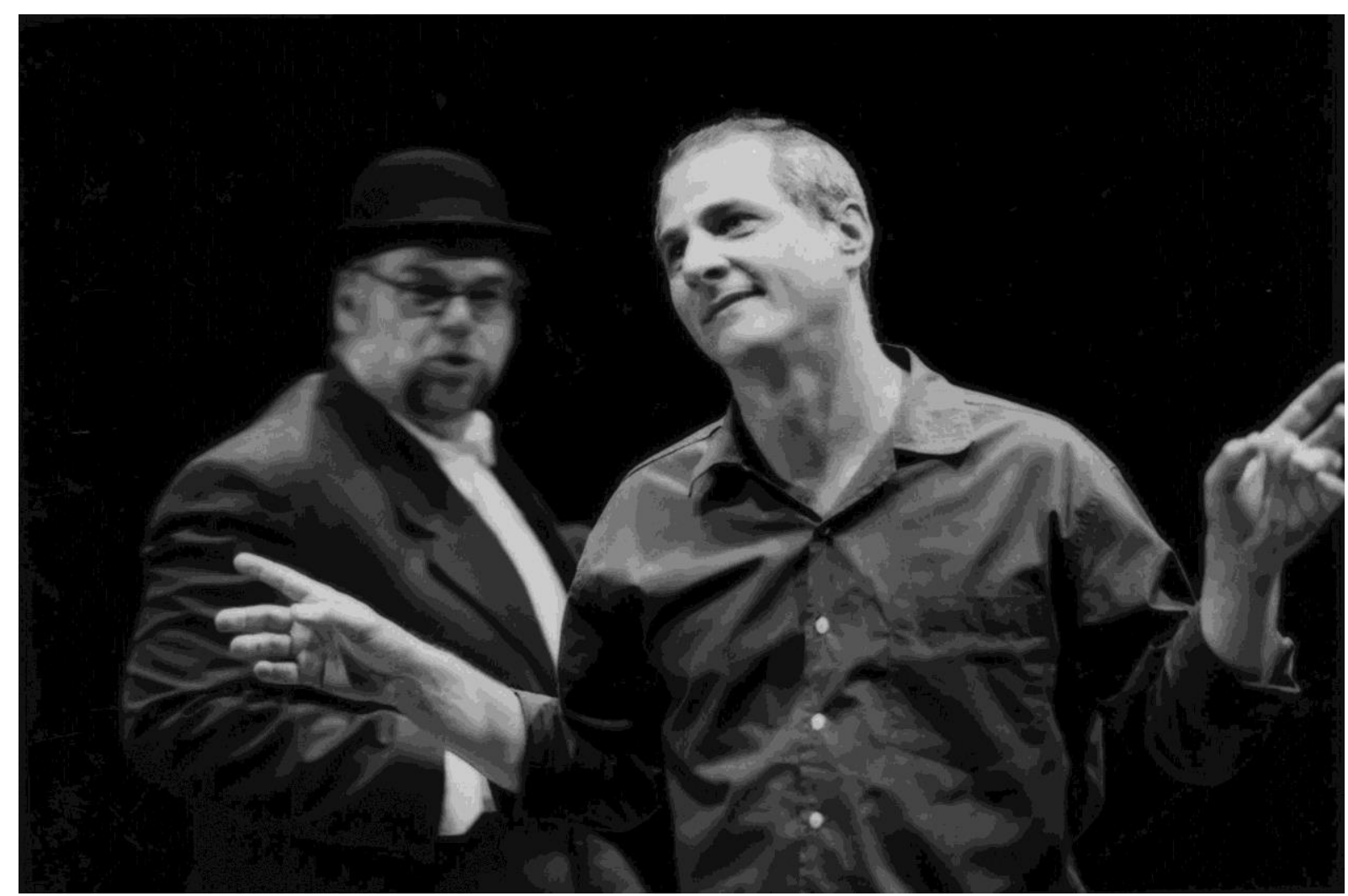

Heitor Goldflus (Juiz) e Ney Piacentini (ex-intelectual). Equívocos colecionados, 2004. Foto: Sérgio de Carvalho.

Visões siamesas (2004)

Antes mesmo de iniciamos os ensaios sobre este projeto, procuramos pelas similaridades entre a obra contista de Anton Tchekhov e a de Machado de Assis. Optamos pela machadiana e com ela fizemos diversos experimentos. Eu, por exemplo, encenei com os colegas o conto Ayres e Vergueiro, em que dois sócios misturam afinidades familiares com negócios escusos. Izabel Lima se envolveu com a Crônica dos burros, na qual os animais discutem sobre a propriedade. Com Heitor Goldflus, não foi diferente: "Eu tomava o metrô com Machado de Assis na mão, escolhendo um conto ou outro e preparando uma improvisação. A Teoria do Medalhão foi um da minha preferência e o propus como uma base para aquele começo de trabalho" (informação pessoal) ${ }^{58}$. Ou seja, o escritor carioca alimentava nossos encontros e assim recebemos o crítico inglês John Gledson e os professores José Antônio Pasta Júnior e Roberto Schwarz, que nos instruíram sobre os aspectos históricos e literários da obra de Machado de Assis. De maneira que, em Visões siamesas:

\footnotetext{
${ }^{58}$ Heitor Goldflus, em depoimento a Ney Piacentini, em 06 abr. 2016.
} 
A inspiração do título vem de As Academias de Sião, conto obscuro e pouco representativo de Machado de Assis, mas repleto de sugestões, cuja excentricidade serviu de estímulo à criação da fábula oriental que o grupo utiliza como pretexto para o exame da suposta alternativa "místico-metafísica" imposta desde sempre à escória social como única saída (MARCIANO, 2007, p. 44).

\section{Além do olhar de Márcio Marciano, a crítica Mariângela Alves de Lima, observou:}

Em sete anos de trabalho, a Companhia do Latão definiu um perfil singular no panorama teatral brasileiro. Todos os espetáculos que produziu até hoje são explorações analíticas das forças sociais em movimento. Em uma visão retrospectiva poderíamos dizer que o drama, na acepção vulgar, está fora de cena porque o que as encenações contemplam é o modo como os indivíduos ou os movimentos coletivos são afetados pelo regime capitalista. Dramático propriamente é o que se conclui dessas representações. Ao todo rememoram para o público o sentimento de opressão de um sistema que sabemos ser uma produção histórica, mas que sentimos como um determinismo. E é exatamente neste interstício, entre o conhecimento e o sentimento das coisas, que a arte pode intervir. São, portanto, espetáculos sintonizados com um fenômeno contemporâneo que afeta a um só tempo a vida cotidiana e intelectual: as coisas que precisam ser transformadas nos parecem, pela sua dimensão e durabilidade, irremediavelmente eternas. É contra os sintomas da rendição incondicional que impregnam de modo tão evidente as instituições que se aparelha essa modalidade de teatro crítico [...] Visões Siamesas, a mais recente criação apresentada agora em um sistema de repertório ${ }^{59}$ em que se incluem espetáculos anteriores do grupo, apoia-se mais no espírito do que na letra de um conto de Machado de Assis. A referência a um só tempo legitima e ironiza o legado crítico dos intelectuais brasileiros. Salva-se o patrono do espetáculo, sabidamente um dos mais argutos observadores da sociedade do século 19. Da sua narrativa o espetáculo utiliza a ideia da duplicidade da escrava e do rei e a jocosa imagem dos acadêmicos produzindo cosmogonias ajustadas às suas próprias necessidades. Há um “céu econômico" decifrado por esses sábios, ou seja, está tudo escrito nas estrelas. Cabe a esses sábios justificar um modo de produção, cuja consequência é a marginalização de imensos contingentes populacionais de qualquer forma de riqueza (LIMA, 2004, p. D9).

As apurações dos dois comentadores indicam similarmente os porquês da obra, cujo acúmulo de uns poucos destrói a vida de muitos. E era esse o assunto da peça: as causas da degradação humana, que não são místicas como querem os sábios da peça. Por esse prisma, não deixava de ser perceptível a combinação Machado x Brecht.

\footnotetext{
59 Trata-se do segundo repertório da Companhia, composto por Auto dos bons tratos, O mercado do gozo, Equívocos colecionados e Visões siamesas.
} 
Sobre a atuação, o projeto requereu uma preparação específica do elenco, pelos ares orientais que a obra adquiriu. Alice $\mathrm{K}$ foi convidada a nos fornecer noções do Teatro Kabuki e do Nô, além do Kyogen. Enquanto a exuberância está presente no Kabuki, no Nô a simplicidade dos gestos e expressões se sobressai. Já o Kyogen é uma variante cômica, apresentada nos intervalos das peças Nô. Com a nossa orientadora, experimentamos, entre tantos recursos, uma vivência com a cerimônia do chá. Ao treinarmos uma postura inclinada para a frente, colocávamos bastões de madeira por dentro das roupas em contato com a coluna vertebral, arrastávamos levemente os pés e fechávamos as mãos ao lado do corpo com os polegares acima dos outros dedos. Isso a fim de nos adaptarmos a um andar não ocidental que eu, por exemplo, utilizei em parte do caminhar do personagem Sr. Tchong, dono de um arrozal que estava sendo desfeito.

Quanto aos personagens, tínhamos Kinara (Helena Albergaria), uma jovem retirante camponesa que via um Rei em seus delírios. O Rei Kalafanko do Sião (Ney Piacentini), a mãe de Kinara: Ganam (Izabel Lima), Mestre U-Tong (Heitor Goldflus), Sai-Bile (Emerson Rossini) e Sai-Baba (Fernando Paz): os acadêmicos do Sião, entre outros que compunham aquele mosaico de figuras humanas ${ }^{60}$. E Izabel Lima nos testemunhou que:

\begin{abstract}
Ganam surgiu de uma improvisação em que contávamos sobre os colhedores de arroz e era, na verdade, uma colheita que já não vingava. Sair daquele lugar seco e falido, ir embora, buscar outra vida, outra possibilidade com a filha Kinara. Desterradas e sonhadoras foram adjetivos que ajudaram nessa construção. Ganam - a que ia se curvando à medida que o espetáculo avançava até sua morte no final, com o corpo sendo arrastado em cena pela filha (informação pessoal) ${ }^{61}$.
\end{abstract}

Sobre Kinara, "que magicamente troca de corpo com o Rei Kalafanko por acordo mútuo, sem perder nenhuma nuance. Evolui de uma frágil inocência a uma arrogância cega, vulnerabiliza-se até as lágrimas. A ilusão da emoção, conseguida com desenvoltura técnica, é o que promove a reflexão" (COELHO, 2004, p. 12).

O que o crítico apontou no trabalho de Helena Albergaria é a não exclusão da emoção nas intelecções do papel e a inclusão do raciocínio nos sentimentos da jovem migrante. Se nunca houve, acentue-se que, no trabalho dos atores da Companhia do Latão, inexiste a

\footnotetext{
${ }^{60}$ Victória Camargo fez a taberneira e Marina Henrique (depois Alessandra Fernandez) atuou no papel da Srta. Chin. A direção musical foi de Martin Eikmeir (em parceria com Walter Garcia), cenários e figurinos de Fábio Namatame, iluminação de Domingos Quintiliano, assistência de pesquisa de Rogério Marciano e dramaturgia e direção de Sérgio de Carvalho e Márcio Marciano.

${ }^{61}$ Izabel Lima, em depoimento a Ney Piacentini, em 03 jun. 2016.
} 
separação entre as duas instâncias: razão e sentimentos. Entretanto, pelo nosso prisma, como queria Stanislavski, não é a emoção que conduz à ação e sim a ação que provoca a emoção.

Por minha vez, além do Rei que mudava de alma com Kinara, interpretei o Senhor Tchong. Reporto-me a essa figura por ela ter-me proporcionado uma metamorfose como poucas entre os personagens que fiz no grupo. $\mathrm{O}$ conjunto de experiências que foram das técnicas de teatro oriental com Alice $\mathrm{K}$ até vestir indumentárias distintas das ocidentais, entre outras, fizeram-me, por alguns momentos, sentir-me como um senhor oriental. Eu não precisava carregar no sotaque (que sequer conhecia), nem fechar os olhos para que ficassem repuxados, mas era uma leve curvatura, um pequeno acento vocal, um reduzido arquear dos braços que me davam a sensação de estar na pele daquele senhor que se desfazia de sua gente vendendo os arrozais.

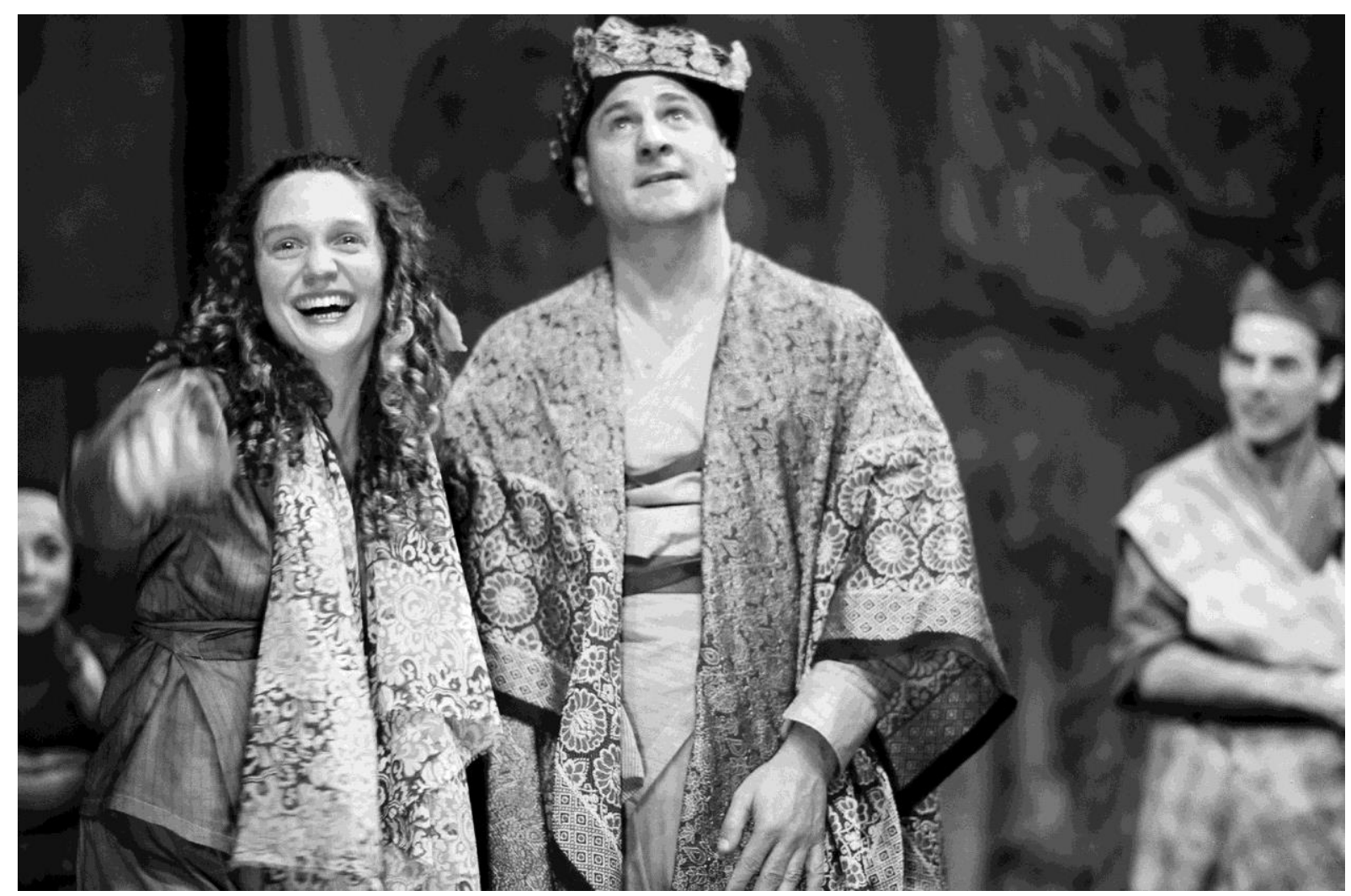

Izabel Lima (Ganan), Helena Albergaria (Kinara), Ney Piacentini (Rei Kalafanko), Helena Albergaria (Kinara) e Emerson Rossini (Deng). Visões siamesas, 2004. Foto: Lenise Pinheiro.

Em outra chave, havia a comicidade dos sábios do Sião. Porta-vozes das forças econômicas (disfarçadas de místicas) esse trio era dividido em um deles (o mestre mais velho) não aderente ao cinismo dos dois seguidores mais jovens. E o humor de tais figuras era carregado de força bruta. Vejamos uma passagem: 
O mestre anda pelo palco confuso, enquanto seus discípulos continuam no proscênio. Vez ou outra se aproxima deles para falar.

SAI-BABA: O velho mestre está desalinhado.

U-TONG: Deve haver alguma alternativa. Não é possível que os nossos destinos estejam traçados no céu econômico.

SAI-BILE: É a cegueira de um pateta.

SAI-BABA: É incrível que eu tenha caído nessa esparrela toda.

SAI-BILE: Ele ainda acredita na crítica da economia política. Nós já estamos na crítica da linguagem.

Subitamente, U-Tong passa a ser agressivo com os discípulos.

U-TONG: Vocês, vocês também têm culpa pela desgraça social.

SAI-BABA: Ora, Mestre.

U-TONG (Grita.): Traidores, traidores!

O mestre avança sobre Sai-Bile e começa a estrangulá-lo.

SAI-BILE: Aaaaaaah!

SAI-BABA: Mestre, mestre!

SAI-BILE: Faça alguma coisa!

SAI-BABA: Mestre! Mestre!

Sai-Baba pega um cajado e bate na cabeça no Mestre com violência. O velho sábio resiste antes de tombar em sangue.

SAI-BABA: Nós não temos culpa! (Bate mais.) Não temos! A desgraça social provém de uma causalidade sistêmica...

SAI-BILE: ... de um determinismo congênito...

SAI-BABA: ... de uma fatalidade randômica...

SAI-BILE: ... uma esqualidez famélica...

SAI-BABA: ... uma idiossincrasia climática... (CARVALHO; MARCIANO, 2008, p. 306307).

Para os atores que representaram esses papéis (Heitor Goldflus, Emerson Rossini e Fernando Paz), apenas a ironia seria insuficiente, assim como somente se coléricos. Da desfaçatez entre eles mesmos passavam às agressões e se voltavam ao desresponsabilizar-se das causas dos males sociais. Traduzindo, no grupo, os porquês de os personagens reagirem desta ou daquela maneira fazem uso do benefício da dúvida, visto que não há um estado (patético neste caso) que dê conta das variáveis que compõem os papéis. Esses sábios primavam sim pelo cômico, mas passavam pelo sarcástico, pelo jocoso, pelo sóbrio e até pelo catártico. Portanto era necessário entender os motivos pelos quais agiam dessa ou daquela maneira, sendo seus comportamentos uma consequência de suas crenças materiais. 
Neste primeiro capítulo, visitamos as peças em que os integrantes do grupo estavam aprendendo a lidar com a dialética na atuação. E mesmo tendo retratado aspectos dramatúrgicos e de encenação, busquei enfatizar como as atrizes e os atores operavam com uma interpretação singular, pautada pelas contradições. Na próxima etapa, vou discutir o alcance dessa fase inicial e os seus reflexos no meu aprendizado atuativo. 


\section{CAPÍTULO 2 - A PRÁXIS DE UM ATOR DIALÉTICO}

Este capítulo será dedicado a discutir a minha prática como ator em três espetáculos que compuseram o terceiro repertório da Companhia do Latão em 2014. Os informes dizem respeito às peças sendo apresentadas aos espectadores, incluindo observações sobre os ensaios e demais etapas que levaram aos resultados públicos.

\subsection{O CÍRCULO DE GIZ CAUCASIANO ${ }^{62}$}

"Nos diários de trabalho, o Brecht escreveu: 'Numa sociedade como esta, a única coisa a ser feita é colocar mensagens na garrafa'. A algum lugar essas mensagens vão chegar" (SOUZA, 2006, p. 58) ${ }^{63}$.

Começarei pela remontagem da obra de Brecht, resumindo-a para que se possa acompanhar o que em seguida será comentado. No prólogo da peça, dois grupos de camponeses decidem sobre qual deles deverá ficar com uma área de terras. Enquanto uma comunidade, que lá criava cabras para produzir queijo, teve que abandonar sua região por causa da guerra, outro agrupamento passou a ocupá-la, defendendo-a dos ataques e elaborando um plano de irrigação para aumentar a sua produtividade. Quando a guerra termina, os moradores, que antes habitavam a localidade, voltam e reclamam seu direito anterior de ficar com as glebas. A disputa é resolvida por consenso e o segundo grupo ganha o usufruto, pois lá promoveram melhorias.

Para celebrar o ensejo, faz-se um teatro que se passa em uma época antiga, na Região do Cáucaso, em que há um confronto no qual a Pérsia derrota a Geórgia. O conflito gera uma mudança no poder georgiano, sendo seu governador degolado pelos príncipes golpistas e a

\footnotetext{
${ }^{62}$ O círculo de giz caucasiano teve duas montagens pela Companhia do Latão: a primeira estreou em 2006 e a segunda em 2014, é de autoria de Bertolt Brecht, com tradução de Manuel Bandeira; Ópera dos vivos teve suas primeiras apresentações em 2010 e foi uma criação da Companhia do Latão com encenação e dramaturgia final de Sérgio de Carvalho. O patrão cordial estreou em 2012 e foi uma dramaturgia de Sérgio de Carvalho sobre o original O senhor Puntila e seu criado Matti, de Bertolt Brecht com tradução de Millôr Fernandes. Como, neste segundo capítulo, vamos discutir a atuação com essas peças já montadas, lembro que $O$ círculo de giz caucasiano foi ensaiada em análise ativa (via improvisações sem que o elenco fizesse, previamente, leituras do texto de Brecht - ver notas 32 e 96); Ópera dos vivos teve seu texto e encenação levantados em processo com a constante participação dos atores e $O$ patrão cordial pode ser visto como híbrido das duas anteriores: foi improvisada com a colaboração do elenco em criações paralelas à de Brecht, mas não abriu mão do trabalho de mesa, com a equipe lendo e discutindo o material em conjunto.

${ }^{63}$ A primeira encenação da Companhia do Latão para essa obra, em 2006, teve como impulso os cinquenta anos da morte de Bertolt Brecht.
} 
primeira-dama escapa esquecendo o bebê do casal no palácio. Uma empregada de cozinha da corte, de nome Grusha, cuida da criança e o primeiro ato da obra narra a sua relutância em cuidar do filho de Natela Abaschvile, sendo que, depois de alguns percalços, a criada decide adotar o menino e, por isso, passa a ser perseguida. No segundo ato, acompanhamos a trajetória de Azdak, um velho escrivão de aldeia, que se torna inesperadamente juiz - função que passa a exercer com métodos peculiares. É este o homem que vai julgar, no último quadro da fábula, quem tem direito à criança abandonada: se a mãe verdadeira ou a de criação, propondo uma solução salomônica para o desfecho.

Como nesta seção darei preferência a discorrer sobre o meu trabalho atoral (o que não excluirá ponderações sobre os meus colegas), precipito que, quando surgia em cena, Azdak hospedava sem o saber, em sua cabana na floresta, o mais poderoso homem da Geórgia, o Grão-Duque (disfarçado de mendigo), que fugia da conspiração dos seus príncipes temendo também perder a cabeça. Após a partida desse estranho visitante, o anfitrião, ao se dar conta de que abrigou um grande e não um miserável, vê-se como um traidor do que para ele era uma revolução popular e não um golpe de Estado e, amarrando-se em cordas, dirige-se à cidade para se entregar.

Iludido que o povo está rebelado, Azdak, ao se deparar com uns soldados em praça pública (que ele supõe serem também revoltosos), lhes diz: "Prendam-me!"64, exibindo as mãos entrelaçadas.

Se na primeira montagem o meu personagem começava em alta voltagem, na segunda versão procuramos uma dupla intenção em sua atitude. Do que me recordo sobre como atuava na nossa versão inicial, eu agia me curvando em direção aos soldados meio embriagados, insistindo para que eles me prendessem. Ao enfatizar a minha autocondenação, inclinava meu corpo para a frente, adequando a postura física às expressões verbais. Porém, logo que recomeçamos os ensaios para a remontagem, o diretor Sérgio de Carvalho sugeriu que eu tentasse oferecer as mãos frontalmente, porém voltando o corpo para trás. Essa decomposição - mãos esticadas para os soldados com a coluna vertebral no sentido oposto - fazia com que a minha cabeça não soubesse ao certo que posição tomar. O intuito não era resolver o problema pelo desenho do corpo e sim procurar uma expressão que se colocasse em oposição à consciência revolucionária de Azdak com, quem sabe, um desejo de ele ser reconhecido como

\footnotetext{
${ }^{64}$ A expressão não consta na tradução de Manuel Bandeira, sendo uma das adaptações feitas pelo dramaturgo e diretor Sérgio de Carvalho sobre a obra de Bertolt Brecht. O correspondente no original a essa inserção é a frase: "Reclamo severa condenação contra mim" (BRECHT, Bertolt. O círculo de giz caucasiano. São Paulo: Cosac Naify, 2002, p. 140) e que fez parte da nossa primeira versão.
} 
alguém capaz de um anti-heroísmo, como nessa estranha atitude de ele se oferecer para ser preso.

Contradição, colisão ou atrito entre duas ou mais forças produz, para nós, movimento e dão dimensão dialética a um personagem. Sendo que, com os cortes e adaptações feitos por Sérgio de Carvalho sobre o texto de Bertolt Brecht, aumentaram as exigências no meu revezamento entre o fazer e o narrar, uma vez que nessa aparição do personagem, ao mesmo tempo que eu contava aos soldados que havia deixado escapar o Grão-Duque, retomava fragmentos do diálogo com aquele nobre disfarçado de mendigo.

O trecho acima descrito tem o intuito de demonstrar como operávamos com as instâncias dramáticas (vivenciais) e épicas (narrativas) no grupo, o que, como relatamos no Capítulo 1, aproximava Stanislavski de Brecht e vice-versa. Quando estávamos em relação dialógica, em que os personagens reagiam através de suas subjetividades, buscávamos a veracidade nos termos stanislavskianos. Por outro viés, se a dramaturgia nos solicitava uma atitude de narradores, interrompendo o fluxo dramático para nos dirigirmos aos espectadores, a esteira seria brechtiana. É preciso dizer que o Latão não se limitou a um uso estanque desses dois modos, cruzando outras possibilidades as quais, a meu ver, contribuíram para uma atualização da atuação épico-dramática, rumo a uma contradição formal e conteudística.

Detalhando a cena azdakiana, aquela primeira sequência se deu de acordo com os seguintes passos:

- Como o segundo ato abria com uma canção ${ }^{65}$, ao final da música eu fazia uma rápida intervenção sem palavras sobre o canto grupal que lembrava Azdak saudando febrilmente a chegada da revolução.

- Após a canção, ao ouvir uma narrativa a respeito do meu papel, aproveitava para pensar nas imagens que as palavras do texto me sugeriam. "Quando deposto foi o Grão-Duque e degolaram o Governador Abaschvile, um velho escrivão de aldeia, Azdak, amarrou-se a uma corda e se dirigiu até a cidade" (BRECHT, 2002, p. 139) ${ }^{66}$. Durante essas sentenças, levava

\footnotetext{
${ }^{65}$ Irmão cobre a tua cabeça/ Irmã vai buscar a tua faca/ É tempo de destrambelhar, é tempo de destrambelhar/ Os grandes estão cheios de queixas/ Os pequenos cheios de alegria/ É tempo de destrambelhar/ É tempo de destrambelhar.

${ }^{66}$ Quem narrava esse trecho era Deborah Lobo na primeira versão e Alessandra Fernandez na segunda (e ambas fizeram o papel de Natela Abaschvile). Helena Albergaria fez Grusha nas duas versões, assim como eu atuei como Azdak. E nos demais papéis estavam: primeira montagem - Carlota Joaquina, Luís Mármora, Cibele Jácome, Rodrigo Bolzan, Mafá Nogueira, Rogério Bandeira, Sidney Frreira e Martin Eikmeier (músico); segunda montagem - Álvaro Franco, Érika Rocha, Daniela Casteline, Fernanda Gonsales, Mafá Nogueira, Ricardo Monastero, Rogério Bandeira e Martin Eikmeier (músico); a cenografia e o figurino foram de Fábio Namatame; iluminação de Fábio Retti e Melissa Guimarães; assistência de direção de Daniele Riciere;
} 
meus pensamentos até a agitação que deflagraria mudanças políticas e sociais, através de visões de gente gritando nas ruas, vendo-me no meio da revolta, eufórico, saudando as pessoas no caminho que me conduzia ao centro da cidade. Ou seja, não havia um deslocamento espacial pelo cenário que ilustrasse o trajeto da minha cabana até a praça, por isso era narrado em sintéticas frases. Minha escolha como condutor de Azdak foi a de apenas ouvir a narrativa e ter em mente o caminho em que via as manifestações populares, pelas quais passava com as mãos amarradas, correndo para onde estariam os militares que me prenderiam.

- Como o que acabo de descrever acontecia somente em minha imaginação, comigo parado em cena, com um simples giro de corpo já me deparava com um soldado, situando-me em um largo, pedindo que me detivessem. Aí entrava na ação dramática com os outros soldados e explicava a eles por que queria ser preso. Ao entender que não me davam crédito a respeito de que o Grão-Duque estivera em minha casa, reiterava como havia sido meu encontro, alternando trechos do meu diálogo com o governante e as falas para os soldados, a fim de lhes demonstrar como tinha me enganado com o visitante em trajes de mendigo. Ou seja, quebrava a ação dramática reportando-me aos outros personagens que estavam dentro da cena e não narrando aos espectadores.

Nesse módulo, eu recuava dos soldados para convencê-los de que merecia ser castigado por ter recebido o poder em pessoa em minha cabana, mas permitindo que ele escapasse enquanto o povo queria o seu pescoço. Isso tudo se passava em minutos, o que me requeria uma tripla atenção: como um integrante de um conjunto de atores-narradores, como o personagem Azdak, sendo que este se dividia contracenando com o Grão-Duque e paralelamente contava aos soldados seu encontro com a autoridade deposta. Para tanto, era preciso algum treino em transitar entre os registros vivenciais e narrativos sem achatar o tempo-ritmo em um só. Com a orientação da direção, percebi que tinha que fazer cada parte em seu tempo, respeitando o compasso dos diferentes momentos.

Se haveria de ser rápido na troca de registros atuativos, não era preciso dar a mesma velocidade nas subcenas, que tinham dinâmicas próprias. O convencimento dos soldados para que me encarcerassem possuía um tempo mais premente do que quando recebia o GrãoDuque na floresta (no qual talvez eu estivesse mais calmo, uma vez que receber um mendigo meio perdido não geraria urgência alguma em Azdak). Se não estivesse atento, faria tudo de 
um só modo, o que atenderia mais a minha ansiedade como ator em resolver três tarefas distintas, prejudicando o andamento de cada segmento da cena (o mesmo problema atoral será debatido mais adiante em $O$ patrão cordial, p. 133-134).

Na sequência, meu escrivão apelava ao soldado líder para que um Juiz o interrogasse e este apontava para um corpo pendurado em uma forca dizendo: “Aí está o Juiz" (BRECHT, 2002, p. 141). A minha tendência, assim que eu visualizava o juiz morto, era a de grassar um entusiasmo, congraçando-me com os soldados, em exaltação denotada por meio de contração muscular e rispidez vocal. Sérgio então me perguntou se meu Azdak não poderia estratificar as ações e eu, seguindo o diretor, depois de ver o magistrado enforcado, pensaria que estávamos mesmo varrendo os opressores e começaria (mas apenas começaria) a me empolgar que outros poderosos também cairiam E só depois buscaria a confirmação junto aos soldados, entre outros passos do meu agir, e se conseguisse cumprir cada obstáculo, não sairia falando o texto forte e alto. Se tivesse que sentir alguma coisa, isso brotaria aos poucos das relações entre o que eu via e previa, das perguntas e respostas que fazia e recebia aos e dos outros personagens presentes. O que seria outro meio que não acionar a minha energia pessoal possuidora de dispositivos para forçar emoções imediatas. Era preciso regular ímpeto e razão, reflexo e reflexão, confiando em que os sentimentos seriam decorrências das atitudes em cena.

Adiante, Azdak em seu itinerário representava, como que por acaso, o próprio GrãoDuque. Isso acontecia porque, depois de aqueles soldados se revelarem uns reacionários e quase terem enforcado também o escrivão, surgia o golpista Príncipe Kazbek (Ricardo Monastero) que, além de ter decapitado o governador, estava atrás do Grão-Duque para eliminar qualquer oposição a ele. Para tanto, Kazbek vinha propor que seu sobrinho assumisse a função de juiz (recém-enforcado pelos guardas). Nesse golpe teatral, Brecht criava um ardil dramatúrgico em que os soldados resolviam pedir a opinião de Azdak (que sobrara num canto desde a entrada do príncipe) sobre a proposta de Kazbek de fazer do seu afilhado o novo juiz. Ao responder que o candidato ao cargo julgasse um caso, o escrivão tinha a ideia de se fazer passar pelo Grão-Duque, para que ele fosse julgado por ter perdido a guerra contra a Pérsia.

Como se pode notar, instaurava-se o metateatro, sendo que eu, que já representava Azdak, teria que fazê-lo se passar pelo Grão-Duque. Recebi então, das conversas diárias e reensaios que costumávamos ter durante a temporada, algo que se aproximava da seguinte observação: "Ney, parece-me que você está imprimindo nessa cena mais a sua prontidão de ator do que como Azdak poderia imitar o Grão-Duque. Repare que o escrivão tem que conferir se seus ataques verbais atingem o príncipe, se ele está conquistando os populares que 
assistem à simulação do julgamento, ao mesmo tempo que o personagem lembra de dados e informações sobre a guerra, cujo acesso ele teve, talvez, como funcionário, os quais podem comprometer Kazbek". Mesmo que os meus quase quarenta anos de vida teatral pudessem ter me antecipado um exame sobre o papel naquela situação, vinha optando, não conscientemente, por um caminho mais conhecido por mim, que era o da agilidade e do vigor que costumava colocar nas palavras de um texto. Ao procurar realizar as observações da direção, pensando antes de responder às perguntas do sobrinho pseudojuiz, voltando-me para os soldados que acompanhavam o julgamento para verificar se as minhas respostas estavam repercutindo neles e ainda olhando as reações do príncipe, diminuí a minha velocidade e prontidão, mudando o meu agir e baixando o tom de voz, antes demasiado alto.

É compreensível que um intérprete ache que capacidade de memorização de longas frases, articulação vocal e força física sejam seus atributos. E, se bem dosados, poderíamos dizer que sim, pois garantem certa comunicação à audiência. Mas é pouco diante da exigência que é se comportar segundo as determinações da história em curso. Ou, para recorrermos aos predicados stanislavskianos, levar em conta as circunstâncias propostas pelo autor (ver nota 38). Correntemente, as informações que necessitamos para nos envolvermos em uma cena já estão contidas na dramaturgia. Basta descobrirmos as especificidades não só dos nossos personagens, como também dos outros papéis da peça. E uma orientação eficiente por parte do encenador só faz aumentar o grau de aprofundamento, consequente na gestação de matizes que dão vida à ficção.

Ao unirmos os dois exemplos anteriores, detectaremos o que Sérgio de Carvalho nomeou como o ator energúmeno. Não no sentido comum, mas aquele que é conduzido mais pelas suas energias no lugar das motivações de seus papéis. Nisto eu me reconheço, uma vez que, se me deixam fazer o que os meus ímpetos imediatistas me ditam, sou bem capaz de atuar com grande empenho e visceralidade, o que não significa que os meus personagens tenham que se agir da mesma forma. Principalmente Azdak, criação ímpar de Brecht, que engendra lógicas inusitadas e tortas, com finalidades ora jocosas, ora lúcidas ou ambas: bêbado, no entanto justo, corruptível, porém revolucionário, ambíguo, inteligente e vulnerável.

Depois de termos retirado os excessos do ator sobre o personagem, ouvi de Sérgio: “Agora que não você está mais encobrindo Azdak com o seu temperamento pessoal, temos que lembrar que ele faz o seu teatro, quando se investe de Grão-Duque". Ou seja, retirado meu exagero, haveríamos de somar uma terceira face à cena, encadeando primeiro o ator à personagem (Azdak) e depois a personagem a um segundo papel (Grão-Duque). 
Em uma das noites das apresentações, antes da peça, pus-me a anotar em um papelzinho as prováveis quantias que os príncipes tinham recebido durante a guerra e imaginariamente escondendo-o dentro de um livro para levar comigo quando deixasse a repartição como escrivão. Foi como se Azdak espionasse os dados oficiais para um dia usá-los contra os manipuladores da população. O que é esse mínimo gesto diante da autoincumbência de criar o ambiente onde minha criatura trabalhava? Por que não me atribuí o expediente de ter para mim como era meu espaço como funcionário? O máximo que fiz foi ver fotografias de lebres e coelhos, já que se fala, rapidamente na peça, que Azdak os roubava de quando em vez. Cheguei a rabiscar, com meu traço precário, os couros desses animais pendurados em seu casebre e, em uma ocasião, sabendo que meu colega Álvaro Franco desenhava bem, pedi e ele o fez, esboços do encontro entre Azdak e o Grão-Duque e os pendurei no espelho da bancada do camarim. Algumas noites depois, Franco me atendeu novamente, desenhando-o bebendo em uma taberna, enquanto ouvia uma discussão entre aliados e detratores dos príncipes e do Grão-Duque.

De modo que me encontrava no meio. Percebia que, ao me propor tímidas iniciativas, ao menos me dispunha a conhecer um pouco mais sobre os rasgos do meu papel e, na contramão, reconhecendo o insuficiente envolvimento que seria preciso para o conhecer todo o seu mundo.

De volta ao cenário como Azdak, após ter enfrentado o príncipe no julgamento simulado (fazendo-me de Grão-Duque) e de tê-lo denunciado em suas manobras para tomar o poder, restaria-me a desgraça. Ao pensar no que iria acontecer comigo, vinham-me subtextos como "por que não fiquei quieto no meu canto...", "que ingenuidade acreditar que as coisas iriam mesmo mudar..." e "burrice encarar logo quem vai mandar em tudo daqui para a frente..."; e ver-me com a cabeça na forca fazia com que me arrependesse do que tinha acabado de causar. Isso tudo enquanto, à minha frente, os soldados iam togar o sobrinho como juiz, conforme havia planejado o Príncipe Kazbek. Ao preencher aquele momento de aparente inanição, com elucubrações sobre quais seriam as consequências dos meus rompantes que haviam desmascarado o golpista, era pego de surpresa ao receber em meu corpo a capa de juiz. Ao rechear com inquietações o andamento de uma cena em que eu aparentemente não agia nem falava, encontrara uma maneira de permanecer em ação mesmo parado, esmoendo sobre minha derrocada, culpa dos impulsos incontinentes do meu papel.

Para seguir à risca o aviso tantas vezes relembrado pelo nosso diretor de que um intérprete sabe o que vai acontecer nas partes de uma peça e o personagem não, enquanto ninguém vinha em minha direção nessa cena da escolha do novo Juiz, eu me sentia ameaçado 
de morte. Como próximo aos meus olhos eu assistia os preparativos para a nomeação do sobrinho (Daniela Casteline) do Príncipe Kasbek, não haveria por que esperar outra coisa senão o meu fim.

Ao ver que o soldado chefe se desviou de colocar a capa de juiz no jovem que se apresentava como candidato para com ela me vestir, passava a me perguntar, segundos após segundos, o que estava acontecendo. Por que me tiram a roupa com a qual estava imitando o Grão-Duque? O que estão querendo comigo aproximando-se com a toga? Inquiria-me de maneira a esquecer que eu, como ator, já sabia que Azdak viria a ser o próximo juiz. Na mesma linha, se eu viesse a favorecer meu colega para ele me encaixar nos braços as mangas da capa, seria uma precipitação técnica, uma vez que o personagem ainda não estava entendendo a irônica mudança dos soldados.

Há ocasiões que pedem resistências às resoluções costumeiras dos movimentos corporais. Carlos Escher (condutor do soldado que vinha com a toga nas mãos) chegou a comentar que ele teria que retirar o que eu vestia (a roupa que Azdak trajava para imitar o Grão-Duque), pôr-me a de juiz e me passar o martelo símbolo da justiça. Sérgio de Carvalho rebateu para que Escher não se preocupasse em agilizar a cena, mas simplesmente atuasse como na situação. Levando em conta que os soldados aprovaram os ataques verbais de Azdak contra o príncipe, talvez o soldado sentisse algum prazer em subverter a expectativa, dando-se o tempo necessário, nem mais rápido nem devagar, para tirar o disfarce de Grão-Duque do corpo de Azdak, colocar nele a toga de juiz e lhe pôr na mão o martelo de julgador.

Por vezes, eu só me sinto agindo quando estou falando em cena, menosprezando os atos sem palavras potencialmente mais significativos. Se eu continuasse a duvidar, sem levantar meus braços para que a roupa entrasse em meu corpo ou abrindo os dedos para o encaixe do martelo em minha mão (o que seria mais uma facilitação entre parceiros do que reações dos personagens), teríamos uma série de pequenos problemas que, somados, gerariam os envolvimentos solicitados pelo contexto. Carvalho salientou para que, logo depois, eu não fosse me sentar na cadeira reservada ao juiz, coisa que levaria os soldados a me empurrarem para ela, segundo a mesma objeção para que um ator não se marque a si mesmo em cena, porém que se deixe levar pelos pequenos incômodos que surgem durante as cenas.

Ao ocupar o que seria o assento do Juiz ${ }^{67}$, ao som de uma música que saudava minha nomeação, eu teria que adaptar Azdak à sua nova e acidental função. O que fiz, antes de tudo,

\footnotetext{
${ }^{67} \mathrm{Na}$ nossa encenação, a maioria das soluções cenográficas, como a cadeira de juiz, era feita com as arcas médias e pequenas que, colocando-as em pé ou unindo-as, criavam outras possibilidades.
} 
foi olhar para o que estava próximo a mim, estabelecendo o círculo de atenção ${ }^{68}$ que envolvia a cadeira improvisada, a toga de veludo e o martelo de madeira com o qual eu colocaria ordem no tribunal. Atentar-me aos objetos e apenas isto, instalava-me ${ }^{69}$ e eu passava a tatear a textura daquele tecido pesado e macio, fechando melhor a capa que estava aberta, erguendo minhas vértebras e me vendo como alguém que agora era respeitado pelos outros. Uma transeunte vinha me beijar a mão, o que para um solitário como Azdak era quase um afago e a conversão de um escrivão em uma autoridade ia se dando aos poucos, até que eu me enxergasse em um tribunal me perguntando quais seriam as minhas posturas diante do júri, réus e advogados. Apontaria ou levantaria o martelo? Promulgaria sentenças? Entre essas perguntas, pensava: “Aproveitaria o cargo para fazer jus aos desfavorecidos, condenando os ricos e absolvendo os pobres?". E ainda, se encontrasse um meu superior, que me havia humilhado, iria à forra? Disparando uma carga contínua de interrogações em minha cabeça, delinearia a transformação do aldeão em Juiz, abstendo-me das questões técnicas como a movimentação da cenografia para o próximo quadro.

Por uma supressão temporal, que dava a entender que Azdak vinha julgando havia algum tempo, ele propõe que a justiça seja levada ao campo, pois: "É bom que ela funcione ao ar livre: o vento lhe levanta a saia e assim podemos ver o que está por baixo" (BRECHT, 2002, p. 157). No seu percurso, o novo juiz visitava uma fazenda onde iria decidir sobre um caso de estupro. Ouvia o dono (Ricardo Monastero), sua nora (Érika Rocha) e um jovem empregado (Carlos Escher), em uma triangulação na qual o fazendeiro provaria que o rapaz havia abusado de sua nora, na ausência do filho. Porém o perspicaz ex-escrivão invertia o jogo e acabava, através de um raciocínio inusitado, por libertar o par de acusados, punindo o mandante da área.

Na retomada dos preparativos para a versão de 2014 da obra, descaí em mostrar à equipe que me lembrava do texto e dos deslocamentos espaciais, ao invés de recriar, como indicava a nossa direção, novos entendimentos sobre as relações da história e, por consequência, das atitudes dos personagens. Sendo o primeiro julgamento de Azdak diante dos espectadores, era mister a calma épica, termo que entre nós da Companhia ficou conhecido como uma tranquilidade derivada da compreensão dos fatores envolvidos em uma equação teatral, com sua conscienciosa execução, sem pressa alguma.

\footnotetext{
${ }^{68}$ Elemento do Sistema de Stanislavski que possibilita a atenção do intérprete ao que o rodeia proximamente como os objetos de cena. Chamado também de círculo da solidão em público.

${ }^{69}$ Instalação: termo usado por Eugênio Kusnet que promove a transferência do ator ao personagem, de acordo com a sua capacidade imaginária.
} 
Com três passos à frente, convencionávamos que íamos do tribunal ao campo, em que eu visualizava (onde o público estava acomodado) os animais, não sem uma curiosidade sobre como o dono da fazenda tinha acumulado tudo que se me apresentava aos olhos, com uma ponta de desconfiança de que apenas com trabalho talvez ele não tivesse enriquecido tanto. A minha admiração pelos seus bois e cavalos carregava uma suspeita, embora estivesse ali para ouvir os protagonistas da celeuma e, portanto, o primordial era atentar aos relatos.

Seria imprescindível para meu Juiz ler nas entrelinhas o que estaria oculto nos depoimentos. Se o indicativo da direção era: "Ney, temos que ver Azdak raciocinando em cena...", cabia a mim articular seus pensamentos. Neste sentido, haveria de me fixar no que os demais personagens teriam a me dizer, observar como se movimentavam e desconfiar do jeito como falavam. Se o fazendeiro tinha tanta segurança no que dizia, por que esperneava? Notei que a milícia do dono empurrara o jovem acusado (já com as mãos amarradas e com a cara encoberta por um pequeno tampo de um cesto de palha) como se fosse um criminoso violento, sendo que, ao retirar a máscara do rapaz, me deparava com um rosto passivo. E havia também Ludovica, a estuprada, que vacilava em seu relato. Teria ela decorado uma palavra ou outra que não lhe cabia na boca pelo seu parco grau de instrução? Se sim, quem a orientara?

Alguma coisa me parecia estar fora do lugar e, portanto, eu teria que verificar se a vítima estava mesmo falando por si. Para tanto Azdak passava a interpelá-la a respeito de seus hábitos alimentares e de asseio pessoal: "Tu gostas de doces? Costumas te demorar ao banho, sentada na bacia?” (BRECHT, 2002, p. 158). Se Brecht se inspirou em seu Sr. Keuner ${ }^{70}$, que é dono de nexo invertido, para esculpir Azdak, eu teria que criar a fonte de onde brotavam tais ideias trocadas. Poderia alimentar minha desconfiança com: "Será que esta mulher não faz uso de sua sensualidade? Uma perna descansa sobre a outra, o que lhe dá um leve desleixo... Se lambuzaria em açúcares?”. Daí então viria a primeira pergunta e, sendo sua resposta positiva, estimaria que ela, talvez, gostasse de brincar com a água entre as pernas enquanto se lavava em louça de ágata. Ao dela ouvir que gastava meia hora no banho de assento, projetava-a divertindo-se sozinha no banheiro.

Assim eu partia para a confirmação da minha hipótese, procurando alguma coisa que auferisse minha suspeita de que ela talvez não tivesse sido obrigada pelo cavalariço Melquias a fazer sexo com ele. Se eu mandasse meu preposto Shauva fincar sua faca no chão e pedisse que Ludovica a arrancasse da terra, veria como ela caminhava. Com esse estratagema,

${ }^{70}$ Histórias do Sr. Keuner é um livro de aforismos de Brecht, publicado no Brasil em 1989 pela Editora Brasiliense. Por recomendação de Sérgio de Carvalho, eu também estudei O juiz da beira, de Gil Vicente, como referência para a constituição do modo de agir e pensar de Azdak. 
checaria se a moça bem se requebrava ao andar e, ao se abaixar para pegar a faca, eu dava o bote: "Parada! Viram como ela rebola?" (BRECHT, 2002, p. 159). No entanto, eu não fazia isso para condenar a provocadora sensualidade de Ludovica, mas como um ardil para fisgar seu sogro que era quem, para mim, aproveitara-se da nora e, pelo ciúme de ela ter ficado com seu empregado, queria condená-lo.

Entrecorto um apontamento feito a mim por Sérgio de Carvalho, em meio aos caucasianos reensaios. Portando o martelo de juiz, derivei para o seu uso clichê, que me fazia falar mais por ele. Típica "muleta" teatral que, não fosse a direção reparar, lá estaria eu manipulando-o a torto e a direito, sem o menor controle sobre o seu uso indiscriminado. Assim como os braços e as mãos, temos que nos precaver para não abusarmos da utilização de adereços, agarrando-nos a eles a ponto de eles nos explorarem e não o contrário. Somente quando um motivo, inerente à palavra ou a um ato não verbal for indispensável, podemos estender o uso de um objeto, contanto que exista um motivo legítimo para tal. Ilustrando, toda a bronca que Azdak dava em Ludovica pela sua meiguice, como um desvio para capturar seu sogro, era acompanhada de um uso ininterrupto do martelo de juiz no ar. Depois da contenção por parte do diretor, passei a mantê-lo o mais parado em minha mão, relaxando-o solto no braço, erguendo-o somente ao proferir a sentença, o que reforçou as intenções das falas, economizando em gestos dispensáveis.

Como se pode notar, eu procurei fazer da minha cabeça um recipiente a ser ocupado pelas abstrações do personagem. E existem outros meios como nos questionarmos acerca do que está entre uma fração e outra de uma ação, através de fatias cada vez mais finas, pois sempre haverá interrogações. Por que ele faz isto? Como chegou àquela conclusão? O que o levou a pensar dessa forma e não de outra. Está suficientemente claro que eu sei o máximo que poderia sobre tal parte do enredo e, caso contrário, o que eu posso fazer para me informar sobre as indefinições? Inquietações, inquietações e inquietações.

O segundo julgamento por Azdak se passava em uma taberna e iria tratar de uma senhora denunciada como ladra por três proprietários rurais. As saídas da mulher para escapar à pressão daqueles senhores eram de ordem milagrosa. Ela alegava que um São Banditus havia se penalizado de sua pobre condição, dando-lhe uma vaca e fazendo aparecer bolas na testa dos capatazes dos donos das terras que vinham lhe retirar a santa bovina doação. Completando o caso, um enorme pernil de presunto em litígio havia voado até ela, entrando pela janela, portanto eram infundadas as acusações dos endinheirados sobre ela.

Falando como atuante, vez ou outra acontece de me derivar nos erros de cenas anteriores, o que me impede de vivenciar o que está em ação. No julgamento da velha, ao dar- 
me conta dessa falha sobre falhas, passei a resistir ao que uma longa fala da atriz Fernanda Gonsales (condutora da ré na cena) me permitia mal fazer, que era aproveitar o momento em que a personagem relatava por que estava sendo acusada, para remoer os deslizes antes ocorridos. "Esqueci uma palavra lá", "troquei de ordem duas frases", "não lembrei daquele gesto" e assim por diante. Esse engano não só me desligava como contrariava a percuciência que qualquer interpretação solicita. O que vale anotar sobre essa questão é que eu, como ator, tenho uma tendência a memorizar a aritmética teatral, descartando sua vivacidade, o que se conseguiria, entre outros meios, prestando a máxima atenção aos outros em cena. Os motivos pelos quais me volto mais aos cálculos técnicos, se não estou emitindo textos, vão desde uma autoeducação atoral pendente às exterioridades cênicas até a falta de treino da concentração.

A consciência que vinha ganhando lendo os livros de e sobre Constantin Sergueievich Stanislavski estava me ajudando a diminuir o problema e hoje me sinto menos dispersivo. Entre os recursos que contribuem para manter o foco está a aplicada observação sobre o que está em jogo: peças do cenário, vestimentas e os personagens com suas relações. Comecemos pelo mais imediato que são os objetos de cena: por experiência, estou certo de que olhar acuradamente para as coisas à mostra contribui e muito para escapar ao arrasto dos nossos pensamentos para possíveis desvios (e que tantas vezes nos assolam) como se descontrair com os erros que inesperadamente cometemos.

Por vezes, é preferível separar os níveis de observação para depois acoplar os dados que conduzirão aos múltiplos focos, como no segundo julgamento de Azdak, ao qual me referia. Não havia segredo: na bodega, à minha frente, rompia um homem com o rosto coberto por um pano, enquanto eu escutava os proprietários me solicitando nervosamente. Eu reparava nas roupas do personagem surpresa e quão grande era o facão em sua cintura. Meu cérebro juntava as informações comigo deduzindo que aquele devia ser o bandido (ou São Banditus, para a velha ré) que tirava dos ricos para ajudar os pobres. Tudo isso me acontecia sem esforços, uma vez que bastava esquecer o funcionamento da máquina teatral e apenas ver o que se me apresentava. Desconcentrados é bem capaz de nos incomodarmos com desencontros, como falas encavaladas ou esbarros de corpos entre colegas. Hoje, depois de tanto sofrer com esquecimentos de palavras minhas e de meus parceiros, deslocamentos espaciais (marcas) que não estavam combinados, prefiro tentar aproveitá-los na história, adaptando meu comportamento para o fictício, que se vincula às personagens e não aos atores.

Dou igual relevo ao alcance de Sérgio de Carvalho aos perímetros das cenas (ver p. 36-37). Como parte de uma ideia em que as reações de todo o conjunto são determinantes sobre o que acontece entre duas ou três figuras pilares de um incidente teatral, nosso diretor 
sempre engajou todos do elenco, principalmente aqueles que, em uma ou outra passagem, não são seus principais. Como os guardas que acompanhavam os julgamentos de $O$ círculo de giz. À altura em que o bandido Iracli (Rogério Bandeira) tomava de assalto o improvisado tribunal-taberna com sua entrada triunfal, um soldado reagia a ele apontando sua lança. Como meu juiz era afeito aos párias e avesso aos fortes, meu diretor me recomendou que eu ordenasse em gestos para o guarda abaixar a arma, liberando o repentino visitante de intimidações. As coisas falam: lança, facão, copos e trouxas de dinheiro que traziam as custas que Azdak cobrava dos que queriam sua justiça - ambiguidade entre corrupção e correção. Ao aguçarmos os sentidos para perceber se estavam sujas ou limpas as taças, afiados ou um pouco enferrujados os objetos cortantes, isso tudo não se aliaria aos demais componentes para nos manter ainda mais atentos em ação?

Voltando aos acontecimentos da peça, depois de uma nova canção que dava fim ao julgamento da velha senhora, consagrando Azdak como o juiz dos desprovidos, uma narrativa corria o tempo e o levava a uma reflexão. A preocupação da direção era a de não fazer daquele fragmento um monólogo com a sobreposição do ator ao personagem. Com a luz me recortando, o violoncelo de Mafá Nogueira me acolhendo e todo o elenco sentado à minha frente, não seria difícil deixar de me exibir, caso Sérgio não redirecionasse o solilóquio de Azdak:

A derrota dos velhos senhores não gerou um novo tempo, mas um tempo de novos
senhores. Eu sustentei a pobreza em magras pernas, enfiei o nariz no bolso dos ricos. O
tempo da confusão e da desordem passou, sem que os grandes tempos tenham vindo. Agora
estás livre Shauva, do freio da razão, das pancadas da minha lógica. Livre, para dar vazão à
tua fraqueza e lamber o traseiro dos superiores e enfiar a bota na cara das criaturas. Teria
sido um tempo maravilhoso se a desordem tivesse durado um pouco mais (BRECHT, 2002,
p. 164).

Diria isso ao meu assistente Shauva, como o próprio texto indica. Todavia, pela aparência genérica da primeira parte desse trecho, eu não me fazia perguntas sobre o personagem, como observou o diretor: "O que aconteceu do último julgamento até aqui? Onde Azdak está agora, em que local da cidade ou do campo? O que o subsidia para espiar a vitória dos de cima sobre os de baixo?”. Foi quando reorganizei as imagens que povoavam a mente do improvisado Juiz naquela hora, lembrando:

a) Do Príncipe Kazbek dizendo que só ficaria em paz quando arrancasse a cabeça do GrãoDuque, enquanto emitia a primeira frase: "A derrota dos velhos senhores não gerou um novo tempo, mas um tempo de novos senhores." 
b) Da velha ladra recebendo o martelo da justiça das minhas mãos e de mim expulsando os proprietários no mesmo episódio, como base para: "Eu sustentei a pobreza em magras pernas, enfiei o nariz no bolso dos ricos".

c) De tapeceiros em fúria antes de serem destroçados pelos soldados reacionários, sobre: "O tempo da confusão e da desordem passou, sem que os grandes tempos tenham vindo".

Uma correlação simplificada, uma vez que eram quadros intrínsecos ao que poderia ter me trazido àquela conjunção.

Na passagem seguinte eu teria, com uma nova reviravolta no poder, que fugir para não ser preso, visto que fatalmente me tirariam o posto de Juiz, prendendo-me e me enforcando. Por que deixariam vivo um sujeito que absolvia os pequenos punindo os grandes? Ao tentar escapar, era cercado por três soldados, os mesmos que tinham me conduzido ao cargo e que, com a reinstitucionalização do governo, voltavam a seguir as ordens dos seus superiores, abandonando o caos que tinha feito de mim um magistrado. Eles me jogavam ao chão e me encurralavam com suas lanças. Depois que passei a mirar as pontas daqueles bastões, senti que crescia o meu temor de realmente ser perfurado por eles e isso consequentemente me imobilizava no palco. Um dispositivo elementar - dar veracidade ao artefato de madeira que mimetizava a lança - foi o que modificou os meus movimentos corporais. Isso se deu por eu ter aguçado a minha observação sobre as coisas que, como a proximidade das ponteiras das armas, impuseram-me medo. A materialização do que a mim se mostrou uma quase realidade foi o que evitou rechaços automáticos.

Procedimento semelhante aconteceu quando me encapuzavam e me arrastavam a uma forca. Como ator sabia que aquele era um momento especial da peça, no qual eu quase sucumbiria, sendo salvo segundos antes de me matarem. Por outro lado, Azdak teria que reagir a cada ação dos soldados, tratando-as como se estivessem acontecendo naquele curto espaço entre o chão e a corda. "Por que me cobrem a cabeça? É isso mesmo, vão me enforcar? O que estão fazendo senhores? Não tenho nada contra vocês..." - e isso eu pensava enquanto era forçado, sentindo mãos e braços me pegando com violência. E em desespero, com medo de ser estrangulado, pioravam as sensações: "Parem! Eu não quero morrer!", "Me arrependo de tudo que fiz...", "Me perdoem!”. Nessa espécie de cena, não é difícil prestar mais atenção à sua mecânica em oposição ao que está ocorrendo a cada instante. Novamente me deparava em luta entre a entrega à imaginação, alimentada pelos mínimos atos e respostas físicas, e o esquema fora do personagem controlado pelo ator. 
O que Eugênio Kusnet desejou, que o ator passasse a pensar como o personagem ${ }^{71}$, concretizou-se em mim quando Shauva (Mafá Nogueira) - um guarda que se sujeitava a quem quer que estivesse no comando (e Azdak o nomeara promotor público) - recebia ordens dos soldados para me chutar. Ele vacilava, mas acabava cumprindo a ordem por ser um tanto fraco de caráter. Veio-me, em uma das noites da temporada, que seria melhor eu apanhar de Shauva e não dos soldados. Vindo dele, o espancamento poderia não ser tão violento a ponto de me matarem. Então, na iminência de apanhar, ao invés de olhar para o meu promotor como quem quisesse dizer para ele não me chutar, mudei para que sim, que me enfiasse os pés. Se fosse para ser espancado, que eu sofresse o menos possível. Ou seja, passei da representação do pavor (reação irrefletida - clichê de ator) para a necessidade de ser surrado (pensada para sobreviver, a exemplo do sobrevivente do massacre de Eldorado dos Carajás (ver p. 67); e da Senhora Luckernidle em Santa Joana dos Matadouros (ver p. 34-36). Aprendizado ou intuição (ou ambos), este evento foi para mim um passo na trilha da atuação materialista, dialética.

A última parte da peça cruzava as trajetórias de Grusha e Azdak, na qual seria decidida quem era a verdadeira mãe do menino abandonado no palácio: se a natural ou quem a criou. Em uma das sessões do trabalho, aguardando nos bastidores ser anunciado como Juiz, notei que desperdiçava o tempo que tinha para me preparar. Depois de um intenso ato em que permanecia sem sair de cena um só minuto, eu me punha a descansar um pouco. Não obstante, pelos treinos que vinha praticando, passei a mudar a minha postura nas coxias e reparei que a arquitetura daquele espaço se assemelhava à de um tribunal: pé-direito alto, tesouras de madeira expostas sustentando o telhado e um veludo que servia de isolamento acústico correspondiam à arquitetura de um salão da justiça. Dessa forma, transformei minha espera para entrar em cena na expectativa de Azdak em arbitrar um grande caso, imaginando: "Veja, meu velho. Quem diria que, um dia, você seria aguardado como o juiz que decidiria o futuro do país. Um pobre diabo, ladrãozinho de coelhos para fazer um assado de quando em vez e ainda vender um couro no mercado negro em troca de uns goles de bebida barata...”. Daqueles elementos que estavam fora do palco me veio esse monólogo interior, que seria interrompido pela chamada do promotor: "Cidadãos de Nuka, Sua Excelência, o Juiz!" que eu dizia a mim mesmo: "Vamos lá, Asdak. E que você saia vivo dessa...".

\footnotetext{
71 “Ao incorporar o personagem, o ator deve entrar no seu pensamento...” Depoimento de José Renato a Ney Piacentini. PIACENTINI, Ney. Eugênio Kusnet: do ator ao professor. São Paulo: Hucitec, 2014.

${ }^{72}$ Também essa frase não consta na tradução de Manuel Bandeira e foi adaptação feita pelo dramaturgo e diretor Sérgio de Carvalho.
} 
Ao entrar no tribunal, o que teria que fazer? Nada. A não ser reparar em como me tratavam, pois disso poderia coletar informações sobre os indivíduos em litígio. Atino tardiamente, enquanto escrevo, que não consultei sobre como são os juízes, nem de hoje ou outrora. Ao mesmo tempo que me desculpo, posto que Azdak era um escrivão que virou juiz adventiciamente. No entanto, poderia ponderar que não eu, mas meu personagem teria estudado o comportamento dos togados, seja para remediá-lo ou evitar seus vícios. Quanto à entrada, o que me diziam os exageros com os quais a empregada Grusha (a mãe de criação) me recebia, ajoelhando-se e me beijando a mão? Quem a acompanhava estacionados à esquerda da arena? Que roupas usavam? Ela mesma estava com um avental sobre o vestido: "Ninguém lhe falou ao menos para que dele se desfizesse? Teria ela permanecido com o avental para esconder um defeito do seu já precário vestido? Ou o conservava para exibir que era uma trabalhadora dedicada? E a mulher do governador e seus guardiões? Estariam ostentando seus casacos elegantes para combinarem com a suntuosidade do local ou como um meio de me pressionar ou, ainda, aquilo seria tão normal para eles que sequer pensaram que destoariam da média dos presentes no julgamento?". Todos esses dados me mantinham alerta, sem interferir no rito coordenado pelo promotor Shauva. Ao cobrar as custas dos advogados (Álvaro Franco e Ricardo Monastero) de Natela Abaschvile (Alessandra Fernandez) - mãe biológica do menino em disputa e mulher do ex-Governador, passava pela minha cabeça que não deveria fazer o mesmo com os pobres, e não porque não o quisesse, mas para evitar receber apenas uns míseros trocados da parte deles. Meu Azdak gostava de dinheiro e não se contentava com pouco. Bebia bons vinhos e, quando podia, satisfazia-se com refeições caras. Por conseguinte, das bolsinhas de couro com moedas que me vinham dos advogados da parte abastada, sentia nas mãos uma falta de peso, o que me levava a pedir mais.

Depois de interromper um dos advogados de acusação que não parava de falar em favor de sua cliente, era a vez de escutar a empregada acusada de ter raptado o filho dos governantes. Porém o exercício, nesse caso, era o de não antecipar as ações: "O que tens a dizer sobre o que disse e ainda dirá esse advogado?”, perguntava eu a Grusha. "O menino é meu", dizia-me ela laconicamente. Se a sabedoria de Azdak estava dizendo a ele para que esperasse ouvindo a criada, eu, como ator, não poderia me render à ansiedade de tapar o silêncio da cena. "É tudo?" (BRECHT, 2002, p. 178), replicaria o Juiz. No que ela acenava que sim. Do que eu especulava: "Será que esta coitada não sabe falar? Ela me parece nervosa...”. Então acenava para que ela continuasse. Titubeando, a criada soltava as frases que demonstravam seus cuidados com a criança e, neste momento no julgamento, a balança pendia para o lado dos pobres. Até que um homem, que já estava ali entre o grupo da criada, 
afirmava ser o pai de Miguel, o menino em disputa. Surpresa no tribunal: uma testemunha imprevista mudava o rumo da disputa: se a criada de cozinha dizia que o filho era dela e aquele homem era o pai, o caso se encerrava. Porém, os advogados contra-atacavam afirmando que aquele era o noivo da empregada e contavam como ela sequestrou a criança do castelo, por ocasião da fuga da corte durante a revolta. A minha única preocupação como julgador era a de acompanhar cada movimento das partes para tomar pé da testilha. Foi bem um daqueles momentos em que um ator tem que confiar na sua escuta de seu papel e que isso o fará responder, quando for chegada a hora. Como hoje penso que atacamos alguém por não sabermos nos defender, Azdak poderia ter se irritado com Grusha por se sentir impotente em favorecê-la.

\footnotetext{
AZDAK: E o menino, é filho das ervas? Que espécie de criança é? Um maltrapilho de rua, um bastardinho qualquer ou é filho de família rica?

GRUSHA: Um menino, como outro qualquer.

AZDAK: Não demonstrou precocemente nenhum sinal de refinamento?

GRUSHA: Um nariz no meio da cara (BRECHT, 2002, p. 181).
}

Era preciso aceitar essa bofetada verbal e o consegui, afinal, com o subtexto: "O que estás me dizendo? Eu ouvi bem? Tiveste a petulância de me desafiar no tribunal que eu comando? Estão rindo de mim? (Pausa) Azdak, seja inteligente. Não se nivele a ela. Até que foi engraçado". Para só depois virem as palavras do autor: "AZDAK: Eis uma resposta que considero importante" (BRECHT, 2002, p. 181). E seguiria pensando: "A danada me derrubou e como eu saio dessa? A imbecil não se deu conta que estou do lado dela. O que faço agora? O caso é muito maior do que eu contra ela. Estou numa enrascada”.

Dar lugar a hesitações em cena (como acontece na vida) foi uma novidade na minha vida como intérprete.

Eu acho que ali houve uma evolução sua como ator, com méritos para a força de vontade e inteligência em estudar o que é importante. Creio que você simplesmente entendeu que é aí onde reside a grande coisa do teatro. O elo entre nós aumentou porque você está menos exibido, sem se preocupar com o efeito do que vem fazendo. De modo que as ligações ficam sinceras. Aquela nossa conversinha na qual que eu lhe disse que Azdak teria que estar preocupado em estudar a Grusha para auxiliá-la e ela o dificultava por não entender que ele estava do lado dela também contribuiu (informação pessoal) ${ }^{73}$.

\footnotetext{
${ }^{73}$ Helena Albergaria, em depoimento a Ney Piacentini, em 18 nov. 2014.
} 
Albergaria e eu revisitamos um tópico do livro de Vasili O. Torporkov ${ }^{74}$, em que Orgon e Cleante se enfrentam sobre Tartufo, figura notável de Moliére, sobre os quais Stanislavski recomendou:

\begin{abstract}
Vocês acabam de interpretar a cena de uma feroz disputa entre duas pessoas e a haviam começado pela discussão, omitindo uma etapa prévia, muito importante, que é a orientação, a auscultação mútua, o acomodar-se às circunstâncias, a busca de uma onda conveniente para uma conversação tão suscetível. Estas sutilezas, estas ações físicas minúsculas se sucedem parcialmente antes de começar a conversação e, em parte, durante as primeiras cinco ou dez réplicas formam o primeiro anel do futuro encadeamento de toda a linha ativa ulterior da cena. Vocês estão esquivando tudo isto, faltando com a verdade" (TOPORKOV, $\mathrm{n} / \mathrm{d}, \mathrm{p} .214)$.
\end{abstract}

Apesar de o mestre russo se referir aos personagens de Tartufo, havia uma correspondência com as criaturas de Brecht que estávamos representando, o que se traduziaem: deveríamos nos medir (Grusha e Azdak) antes de nos enfrentarmos.

Finda a missão em atribuir "As crianças para as mulheres maternas” (BRECHT, 2002, p. 190), dando a Grusha, a criada, o direito de educar o menino que adotara, Azdak desapareceria. Não tenho como omitir que essa criatura, sem dúvida mais inteligente do que eu, modificou-me não apenas como ator. Um sujeito torto, incorreto e generoso, desapegado. Vicioso, gentil e inconformado, possuía a consciência de que seu poder era limitado e mais do que passageiro. Portanto, tinha que fazer o possível antes que as forças regressivas o expulsassem da vida pública. Voltaria para a sua cabana? Viajaria para longe? Morreria beberrão? Como sobreviveria? Quem sabe errasse um tanto, se perderia e, doravante, não sem tristezas, continuaria a ler, refletir e passear até que uma nova ideia o inquietasse a agir. Com ele aprendi a errar.

\footnotetext{
${ }^{74}$ TOPORKOV, Vasily Osipovich. O teatro de Stanislavski. Havana: Ediciones del Pueblo, (sem data).
} 


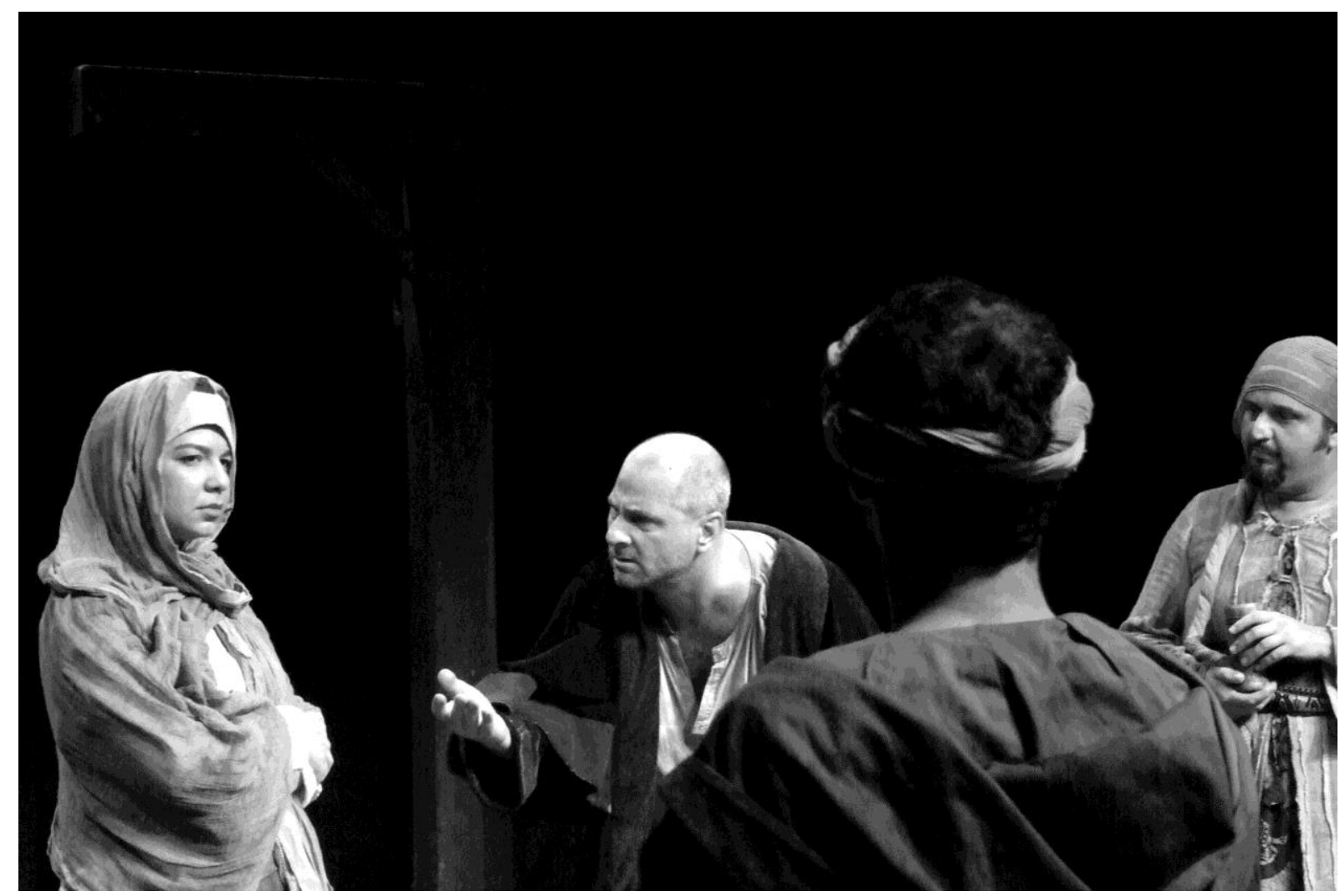

Cibele Jácome (velha ladra), Ney Piacentini (Azdak), Rogério Bandeira (Iracli), Luiz Mármora (proprietário). O círculo de giz caucasiano, 2006. Foto: Sérgio de Carvalho.

Outros papéis

Além de Azdak, nesse espetáculo fiz outros personagens, como o governador degolado na conspiração promovida pelo Príncipe Kazbek, logo no início da fábula. Na retomada da obra em 2014, perante a responsabilidade de conduzir uma das grandes figuras de Brecht - o escrivão Azdak tornado juiz, sequer tinha aberto em mim espaço para levar adiante os contornos de outros papéis. Fazia-os com reduzidos traços internos, seguindo a antiquada fórmula: papel pequeno-pouca dedicação. Embora tenha passado a pensar sobre eles e isso provavelmente se deveu a uma relativa maturação do meu trabalho sobre um dos protagonistas da peça e também como consequência das leituras a respeito da arte de representar que vinha fazendo naquela segunda temporada em que a peça esteve em cartaz.

Na nossa montagem, compúnhamos um coletivo de narradores que, de acordo com o desenrolar da história, iam assumindo seus personagens. Especialmente a primeira cena era propositadamente fragmentada, em um revezamento de breves narrativas e ações, com todo o elenco sentado no palco e dois ou mais atuadores levantando-se aqui e ali, para fazer avançar a descrição do golpe articulado pelos príncipes contra o Grão-Duque e os seus governadores. 
Narrar a respeito do contexto e/ou de um personagem e investir-se deles era uma das atribuições dos intérpretes na Companhia do Latão, como já apontei, posto que o grupo adotou essas funções em sua práxis épico-dialética. De modo que, em seguida ao prólogo em vídeo $^{75}$, eu anunciava: "Outrora, em uma época sangrenta, numa cidade chamada a réproba, a maldita, vivia um Governador de nome George Abaschvile..." (BRECHT, 2002, p. 51) e colocava em minha cabeça um pequeno gorro que indicava ser eu mesmo o governante. Entre a descrição histórica e o viver aquela figura, passava eu desapercebido por uma zona de sombra. Hoje constato que operava como que por um reflexo cognitivo, menos ciente do binômio fazer-narrar ou narrar-fazer do que pelos vinte anos de práticas.

Independentemente da junção ou separação entre as duas formas de representação, foi somente no final da última temporada que dei uma atenção maior ao meu governador. Consequentemente, como eu (ator) sabia que adiante ele (o personagem) pediria para tomar conhecimento de uma mensagem sobre a guerra apenas depois do banquete daquele domingo de Páscoa, punha-me a conceber imaginariamente como teria sido o grande almoço em seu palácio. Fazia isso durante os quinze minutos em que era projetado o documentário prévio à peça, ao qual assistíamos sentados no palco, de costas para a plateia e em frente a uma tela que ficava no fundo da cenografia. Assim figurava de que maneira os convidados estariam posicionados no banquete, quais pratos seriam servidos se as taças de bebidas eram de vidro ou de metal, entre outras divagações que me vinham antes mesmo de nos revelarmos ao público.

A escuridão em que nos encontrávamos durante a projeção do curta-metragem me conduzia mentalmente ao interior dos aposentos daquele governador que, na minha concepção, cultivava momentos de introspecção mística a ponto de ajoelhar-se em um altar dentro de seu quarto para pedir proteção a si e aos seus.

Como na ocasião eu estava lendo a Bíblia, vinham-me associações como a de que George Abaschvile via-se como um protegido pelas divindades cristãs-ortodoxas, de cujas iconografias eu tinha vagas lembranças de uma exposição de arte russa que tinha visto havia muitos anos. Será que ele acendia incensos durante suas rezas? Quais eram as frases que ele pronunciava enquanto, de olhos fechados, falava em silêncio aos céus? Noite após noite, com a imaginação fui mobiliando o quarto daquele homem: tecidos transparentes sobre seu dossel e tapetes cobrindo o piso de pedra polida.

\footnotetext{
75 O prólogo do nosso $O$ círculo de giz caucasiano era exibido em vídeo que mostrava uma comunidade do Movimento dos Trabalhadores Sem Terra (MST), em uma oficina conosco, discutindo e fazendo exercícios e cenas sobre o prólogo da peça escrita por Brecht.
} 
Mais nítidos eram os passos que o meu Governador dava rumo à morte. Ludibriado pelo Príncipe Kazbek, eu seria humilhado antes da minha capitulação. Para tanto, antes de me posicionar no umbral, arrecadava os desenganos de George Abaschvile, martirizando-me pela ingenuidade em pressentir os embustes do meu parente. Forçado a me ajoelhar, recebendo suas corrosivas palavras, rememorava que não veria meu filho crescer.

\footnotetext{
Não queria ter que fazer isso, meu irmão, mas junto com o Grão-Duque deverão cair todos os seus Governadores. Dá-nos a honra de erguer o seu busto. Não precisas mais de um arquiteto, a ti basta um marceneiro. Já não vais a nenhum castelo, vais para um buraco na terra! Levanta e olha um pouco em redor, ó cego! (BRECHT, 2002, p. 61).
}

Soerguido, apavorado olhava o mundo pela última vez.

Relato também meu envolvimento com um padre casamenteiro, encarregado da cerimônia entre Grusha e Iussup (Mafá Nogueira). A festa fúnebre, abertamente cômica, apresentava um quarto na casa de uma senhora que aceitara casar o seu filho moribundo com Grusha, em troca de dinheiro. O arranjo havia sido feito entre a mãe (Fernanda Gonsales) de Iussup e Laurenti, o irmão (Álvaro Franco) da protagonista que, depois de ter dado abrigo à Grusha em fuga com sua criança, viu-se obrigado por sua esposa a se livrar da irmã. Seu plano era conseguir um marido para Grusha, que carregava uma criança, o que resolveria a falta de um pai para Miguelzinho e, como o noivo estava à beira da morte, ela não precisaria desistir de esperar pelo soldado Simão Chachava (Rogério Bandeira), com quem havia se comprometido no início da fábula.

Como padre, eu tinha a função de promover a união entre um moribundo e uma mulher contrariada, vítima de sua malfadada opção em cuidar de um filho de nobres. Eu chegava à casa alcoolizado e me dirigia ao quarto em que se daria o casório, em função da prostração do noivo no leito. E registro outro caso consequente da quase inercial tendência que temos de nos anteciparmos enquanto atores sobre os personagens: como atuante sempre soube que me depararia com um semivivo deitado na cama. Das duas uma: ou poderia conceber que o acompanhante do padre já tinha lhe passado o caso ou, como personagem, teria que me perguntar (internamente) sobre o inusitado da situação: "Para onde estão me levando? Meu Deus, é um cadáver? E é ele o noivo? Se eu soubesse disso não teria bebido tanto...".

Tardiamente reparo que continuo não dando a devida importância aos pequenos papéis, desprezando a ideia de que não importa o tempo de permanência em cena das nossas criaturas cênicas, pois mais vale a riqueza que podemos descobrir, dando vida a esses seres irreais. E opondo retrocessos e conquistas, sublinho o que considero um ganho ético sobre os 
ensaios nesta mesma passagem. O maior volume de texto da cena do inusitado matrimônio era meu, o que me deixava impaciente com o que era um preconceito da minha parte em relação à forma como a atriz Fernanda Gonsales (na pele da dona da casa) absorvia as orientações da direção. A minha rasa postura era a de me perguntar em silêncio comigo mesmo: "Quanta demora antes de eu entrar em cena e dar o meu texto...”. Porém, ao respirar, percebi que Sérgio de Carvalho tratava com Fernanda as implicações do ponto de vista daquela mulher, fazendo com que ela buscasse os problemas físicos de alguém que tem um filho inerte e sem reações, o que a levaria a responder por ele e a agir em seu nome. Como mãe, ela estava entre a pressa de acabar com um falso compromisso para receber o dinheiro do acordo e ter que aparentar ser verdadeiro aquele ajuste. Foi quando entrevi a paciente troca entre diretor e atriz, lembrando o quanto era proveitoso quando uma tal ordem de envolvimento acontecia comigo. Ora, se eu recebia toda a atenção de Sérgio junto aos meus personagens, por que os meus pares não teriam o mesmo direito? De quebra, notei que o pivô daquela sequência era a mãe e não o meu padre que tinha mais falas a dar. Em dramaturgias bem urdidas nem sempre as palavras dão o tom das relações cênicas. Por vezes, são as atitudes dos que não dizem ou pouco se manifestam verbalmente que expressam o que interessa. Em um autoexame, sentime mais à vontade nos ensaios, ao invés de me impacientar com o tempo entre Sérgio e Fernanda, tratando de voltar-me ao que acontecia antes de o meu padre chegar ali. Por exemplo: se vinha bêbado, cheguei a pensar que aquele poderia ser o terceiro ou quarto casamento que eu havia celebrado no dia e, aceitando uns copinhos lá e cá, ao chegar à casa de Iussup já me encontrava torto. Arrematando: é melhor usar nossas energias nas tantas tarefas que temos com os nossos papéis do que nos incomodarmos com o dispêndio que cada parceiro precisa para trabalhar os seus problemas.

Na Companhia é comum nos desdobrarmos em mais de um papel e, assim, concomitante a Azdak, ao governador e ao padre, havia também o funcionário de uma estalagem de estrada, que me era particularmente querido, por me acender a imaginação sobre quem seria aquele sujeito que obedecia ao dono do hotel. Mesmo eu tendo vinte anos a mais de idade do que Carlos Escher (dono do hotel), sentia-me mais novo e creio que ele se sentia mais idoso do que eu naquele episódio da peça em que Grusha fugia com a criança e tentava se disfarçar como uma fidalga na presença de duas hóspedes ricas. As três teriam que ficar num único e mal-arranjado quartinho que restara da hospedaria lotada e, como auxiliar, eu as acompanhava com um livro nas mãos. Havia pego, como objeto de cena, um amarelado livro 
de Taine ${ }^{76}$ que me fazia supor ser o moço um estudante em um seminário das proximidades e, sempre que sobrasse um tempinho, ele estaria lendo.

E, de fato, isso eu fazia nos bastidores antes do patrão me convocar. Numa aparente dispensável dedicação a essa rápida persona, reconheço que, se deixei de constituir como deveria outros miúdos personagens, aqui a autocrítica é dispensável pela simples razão de que uma antiga publicação, resgatada ao acaso no depósito da sede do grupo, levou-me a vivificar àquele atendente. No enredo, meu funcionário fora gentil com Grosa depois de um escândalo causado pelas madames ao descobrirem a origem humilde da criada. E da minha simpatia de classe à empregada em fuga, surgia uma das sentenças que mais me agradavam em toda a peça: "Qual o quê? Nada mais difícil do que se disfarçar de gente desocupada. Se elas descobrem que limpas teu cu tu mesma, estás perdida. Espera um instante, vou te trazer um pão de milho e duas maçãs". E comovia-me ao despedir-me de alguém da minha laia que jamais veria novamente, indicando a ela: “[...] na encruzilhada, toma a esquerda" (BRECHT, 2002, p. 87).

Completando o painel das minhas intervenções na empreitada, teria que me voltar a um serviçal do palácio e a um soldado. Desta feita, ao perceber que os executava mecanicamente, passei a dar vazão a alguns lampejos me vinham durante as últimas sessões da obra. Então, logo que a mulher do governador fugia esquecendo o bebê, uma outra de suas empregadas (Daniele Casteline) recolhia a criança do berço e a colocava nos braços de Grusha, que era rodeada pelos outros criados e entre eles um meu opaco servidor sem nome nem função definida. Em nada ele interferiria nas ações se apenas entrasse, ficasse na posição e, nas suas deixas, emitisse suas duas frases. Era como me portava até que me perguntei quem era aquele pobre homem, se tinha família, se catava lenha ou amassava uvas. Não cheguei a traçar sequer um pedaço da vida dele, no entanto essa simples curiosidade fez com que eu não o deixasse à solidão de quem nunca recebe uma visita. $\mathrm{O}$ meu soldado, integrante da tropa que buscava a recompensa oferecida pelo Príncipe Kazbek aos resgatadores do herdeiro, tampouco tinha cor, idade ou sabia se voltaria para sua família em alguma aldeia se não estivesse em serviços militares. Sem dúvida, não ter cuidado deles foi uma falha. O que me impedia de considerá-los dotados de vida como todos os personagens da peça? Que pobreza artística os ver como menores por não terem falas e quão limitado era equalizar o meu empenho investindo apenas nos papéis que tinham um maior número de palavras na dramaturgia.

\footnotetext{
${ }^{76}$ TAINE, Hypolite. Do Ideal na Arte. Rio de Janeiro: Companhia Brasil Editora, 1939.
} 
Porque ele jamais terá interesse real pela vida dos outros. Jamais tocará o coração da relação ética - a preocupação com o sofrimento alheio. E mesmo aqueles artistas com pensamento bom, com senso ético e "sexto sentido para a história", terão que se haver com essa nossa época medíocre. Sem tempo para lamentações, resta a alegria do aprendizado (CARVALHO, 2014, p. 33).

Sérgio de Carvalho faz uma relação entre o caráter dos atores e a disposição para enfrentar os problemas fora e dentro da cena, a fim de que abrir espaço à criação e depositar no prazer do conhecimento a esperança produtiva do trabalho artístico. Um antídoto às limitações a que estamos sujeitos quando enfrentamos os afazeres teatrais, como as nossas diminutas, e não menos importantes, participações em cena.

Um desvio atoral

Como introdução ao que guardo como um acidente dessa minha fase, reitero que, à época do Repertório 2104 da Companhia do Latão, como doutorando vinha revisitando a literatura acerca do Sistema de Stanislavski, incluindo seus mais próximos discípulos. De maneira que quanto mais analisava os livros sobre atuação, mais crescia a vontade de aplicálos nas performances em curso. Volta e meia me pegava suspendendo tais leituras, pois as associava aos personagens que estavam sob minha guarda, o que gerava um estreito vínculo entre teoria e prática. Dia sim e dia também, alguma coisa eu propunha a mim mesmo ou aos meus colegas, com o intuito de acrescentar novos dados sugestivos às circunstâncias das peças e aos seus respectivos papéis.

Sobre Azdak, para me limitar a um só exemplo, da cópia que tenho em espanhol de $E l$ Evangelio de Stanislavski, na parte em branco dos versos das suas páginas, anotei os seguintes rascunhos de uma carta e a descrição do avô do escrivão-juiz:

"Meu neto,

Se eu morrer, quero que saibas que tiveste em mim um homem que lutou para que a nossa vida melhorasse. Não desejo que cultives ódio aos ricos para quem temos que trabalhar, vendo pela janela como eles aproveitam a mesa. Não. Quero apenas que sejas honesto. Mas que não aceites ser subjugado se te tratarem como um escravo a serviço deles. Cuidado com o excesso de humildade e se te livrares da pobreza, não faças o mesmo que fizeram conosco. Tente promover alguma justiça porque mesmo uma pequena ação...”

“Gregori Azdak: sapateiro. Aos bem-nascidos da sua região, fornecia calçados que fazia de peles de bois e de carneiros para homens e de peles de coelhos e lebres para 
mulheres. Por frequentar as casas abastadas, começou a desconfiar de como toda aquela opulência tinha se formado. Quando soube que havia um movimento contra a miséria, foi lá se meter. Vivia só com o neto, pois sua mulher e filho tinham morrido de doenças de pobres. Conseguiu mandar o menino para um presbitério que ele pagava com seu trabalho e frequentava as reuniões dos artesões de Pérsia, nas quais compareciam ferreiros, tecelões, marceneiros, tapeceiros e sapateiros. Lívio Azdak (o neto) viu coisas no mosteiro que o marcaram: frades se empanturrando de vinho, aguardente e comida. Freiras escapando à noite. Mas estudava com medo das represálias dos párocos professores que castigavam os meninos que não faziam as lições."

Também sublinhei a parte abaixo, enquanto lia Las Lecciones de "régisseur",77, de Nicolai M. Gorchakov sobre seu convívio com Stanislavski:

Está absorta em sua ideia. Sua imaginação a submete agora. Vê atos de sacrifícios do que tem lido e escutado. A casa que habita está construída sobre um antigo campo de batalha onde se travaram furiosos combates. Quantas lendas ouviu em sua infância sobre essa grande batalha. Vê seu irmão mais velho, experimentado soldado, defendendo valorosamente jovens recrutas. Vê um oficial ceder seu próprio cavalo ao comandante quando matam o animal de seu superior. A batalha não terminou ainda. As balas de canhão ainda estão caindo, quando algumas mulheres em toscos vestidos cinza se movem de um ferido a outro. Essas mulheres se apressam para vedar as feridas e os ajudam a manter-se em pé ou recostarem-se mais comodamente. É aqui que uma delas é alcançada por um estilhaço de granada. Com um débil lamento se deixa cair junto a um dos que estava por ajudar. Mariana vê que essa mulher é ainda muito jovem. O que foi que a fez dar sua vida para salvar a um estranho que nada significava para ela? (GORCHAKOV, 1990, p. 53-54).

Stanislavski produzia uma segunda literatura sobre a de Charles Dickens e eu, atingido por suas missivas, aventurava-me transferindo o romantismo de A batalha da vida para a parábola política e poética de Brecht ( $O$ círculo de giz). Se o inventivo mestre criava imagens de guerra paralelamente aos devaneios de uma rapariga, em um pacífico jantar burguês do século XIX, procurei, naturalmente sem a qualidade dele, exercitar o que se passaria com meu Azdak, quando este, diante dos soldados que o pressionavam a respeito de uma canção revolucionária por ele cantada, mencionava seu avô. Escrevendo nas próprias publicações que estudava, busquei lastrear uma figura que não aparecia no espetáculo, mas que existiria nas

77 GORCHAKOV, Nicolai. Las lecciones de "régisseur” de Stanislavski. Montevidéo: Ediciones Pueblos Unidos, 1956. 
memórias do meu personagem. Simplificando, o que fiz foi uma transferência do que Constantin Sergueievich propunha como memória de Mariana (na adaptação para teatro do romance de Dickens) para uma das infinitas lacunas biográficas (que seria a do seu avô) a serem preenchidas na trajetória de Azdak.

Com tal aplicação, como poderia ter acontecido tamanho equívoco como anunciado no início deste subcapítulo? Voltemo-nos à outra faceta da minha biografia: durante dez anos, entre 2002 e 2013, tomei parte na diretoria da Cooperativa Paulista de Teatro ${ }^{78}$.

Apesar de em 2014 eu não mais estar na condução da entidade, havia compromissos junto à militância cultural que me recolocavam na arena dos debates sobre os impasses do nosso setor. Na semana em que encerraríamos as apresentações de $O$ círculo de giz caucasiano, eu também me engajara na realização do II Congresso Brasileiro de Teatro, em Florianópolis, Santa Catarina, e acabei experimentando um desgosto daquela fértil fase de pesquisas acadêmicas aliadas às práticas atorais. Se por quase toda a minha vida profissional me dividi atuando e produzindo teatro, por alguns dias daquele segundo repertório houve um choque entre o estreitamento da aplicação à atuação e as atribuições fora da Companhia.

Ao trabalhar para o Congresso e cuidar do artístico e do doutoramento, minha concentração foi furtada pelos compromissos inadiáveis, como a redação de um artigo para o jornal Diário Catarinense ${ }^{79}$ e a preocupação de qual seria o teor das minhas intervenções nas discussões políticas sobre as lutas da categoria. As sessões de $O$ círculo de giz caucasiano eram de quarta-feira a sábado e eu iria a Florianópolis no domingo, último dia do encontro. Na quinta-feira à tarde mandei o texto para o jornal e, a caminho do teatro, dei uma entrevista por telefone a um jornalista de Brasília sobre os entraves do meio teatral. O meu estado geral naqueles dias era outro, se comparado aos outros em que chegava mais cedo, com um tempo para ler antes de me aquecer e ainda receber as correções da direção da apresentação da noite anterior. Para piorar, não resisti à tentação de consultar os e-mails via aparelho celular e lá

\footnotetext{
${ }^{78}$ Fui vice-presidente por dois anos (2002 a 2004) e depois presidente da Cooperativa Paulista de Teatro por oito anos (2004 a 2013). Entre 2010 e 2016 ocupei a presidência do Centro Brasil ITI - Instituto Internacional de Teatro - ligado à Unesco. Esses cargos e outras atribuições, como o de coordenador de produção da Companhia do Latão de 1997 a 2006, interferiram na minha qualidade artística e a escolha por se abster de quaisquer outros trabalhos paralelos para centrar-se apenas no ofício da atuação não é uma decisão fácil, material e existencialmente falando. É preciso ainda que se leve em consideração que o teatro não comercial brasileiro muitas vezes não tem estrutura suficiente para manter, em seus quadros, não artistas que se dediquem a apenas à gestão, tendo, por vezes, as funções de produção que serem assumidas por parte da própria equipe de criação. Um terceiro aspecto era a aposta de que, assumindo a frente das nossas organizações, os nossos planos para as políticas públicas teriam mais chances de progredir. Hoje, mais consciente das demandas criativas para atuar, penso ser melhor poder trabalhar somente como ator.

${ }_{79}$ O texto "Tentativa de unidade" foi escrito em parceria com a atriz e professora Fátima Lima e publicado no Diário Catarinense de 30 ago. 2014, Caderno Cultura, p. 01.
} 
constava uma resposta da editora do jornal pedindo urgentes mudanças no texto. Respondi dizendo que só poderia nele mexer por volta das 23 horas, quando voltasse para casa, depois da apresentação e pensei: "Chega, agora tenho que me concentrar..." para a sessão que começaria às 18 horas. Qual não foi a minha surpresa ao saber que a mesa de luz estava com problemas e que só começaríamos uma hora ou mais além do previsto, o que aumentou a minha desconcentração, pois atrasaria o envio do texto para o jornal. Fiz o primeiro ato da peça pensando, a cada vez que saía do palco para acompanhar as cenas dos outros atores, nas modificações do artigo sobre o Congresso, o que causou tensão em meu pescoço e na minha lombar. No segundo ato a coisa melhorou porque entrava para não sair de cena como Azdak, o que evitava maiores dispersões.

Porém, no sábado, não sei ao certo se pela viagem que faria no domingo logo cedo ou pelo acúmulo de preocupações extras sobre o meu trabalho como ator, aconteceu o pior. $\mathrm{Na}$ sexta-feira eu já havia me desviado na primeira cena do escrivão, repetindo sem querer, na terceira frase, palavras da sentença anterior para a qual, por sua vez, pela persistência nos ensaios e apresentações, eu conquistara alguma impregnação de imagens ao texto na visita do Grão-Duque à minha cabana.

Cheguei a não mais me preocupar com o texto por estar contaminado com as lembranças do personagem, tanto que desenhei alguém andando entre as árvores próximas ao casebre de Azdak, como também rabisquei o interior da choupana, que seria feito de tábuas de madeira, com ganchos sustentando panelas e um armário pregado em uma parede, onde ele guardava queijos e vinhos, entre outros alimentos. No entanto, isso não foi o suficiente para combater os escapes que me rondavam naquela semana, comigo esquecendo uma parte do texto por alguns segundos o que, mesmo sendo imperceptível ao público, fez aumentar minha perturbação. O fosso se abriu quando, em ação, fui pegar a capa do Grão-Duque dos ombros de Shauva, mas ela não estava lá (Mafá Nogueira a esquecera nos camarins). Susto! Solucionei o erro de contra-regragem do meu amigo tirando a veste que ele mesmo usava e dizendo aos soldados: "Ele (me referindo ao Grão-Duque) usava uma roupa parecida com esta", no lugar de "Esta é a roupa dele". Entretanto, aquela mesma vestimenta seria usada um pouco mais adiante, pois quando visse a capa no chão (que sobraria dessa primeira cena), Azdak teria a ideia de se fazer passar pelo Grão-Duque. Uma preocupação extraficcional atrás da outra, todas fora do arco do personagem, retiraram-me da vivência das situações imaginárias, fazendo com que eu me debatesse muito mais como pessoa do que como escrivão. O certo é que não consegui recuperar minha confiança no papel, o que fez voltarem as tensões físicas que se intensificaram a ponto de quase não sentir os meus pés no chão. 
Explicitamente, apenas errei uma palavra ou outra do texto, fruto da falta de envolvimento com as situações. Ao acabar a apresentação, estava atônito com tamanha regressão de quem vinha lutando para se aprofundar na história e entrar nas veias do aldeão transformado casualmente em juiz.

Conclui que não haveria mais como me fraturar entre o ofício de ator e atribuições paralelas como produtor, gestor e/ou ativista cultural, caso eu quisesse me envolver ainda mais com a interpretação. Contudo, incongruentemente, dependendo da nossa realidade econômica, não há como fugirmos dos "ossos do ofício".

\subsection{O PATRÃO CORDIAL}

Em tempos nos quais imperam discursos apologéticos tanto sobre o capitalismo triunfante quanto sobre a pós-modernidade inescapável, vale a pena querer ouvir o que a Companhia do Latão tem a dizer. Bertolt Brecht e Sérgio Buarque de Holanda continuam atuais, e os temas encenados em $O$ patrão cordial repercutem diariamente na vida brasileira ${ }^{80}$ (ANDRADE, 2013).

Volto-me agora a $O$ patrão cordial, versão da Companhia do Latão para $O$ senhor Puntila e seu criado Matti, de Bertolt Brecht. Observaremos nossas últimas apresentações de 2014, eventualmente recuando até os ensaios e temporadas a partir de 2011 e, como já o fizemos em outras peças, sintetizo o espetáculo para que nos sirva de guia nas discussões que a ele se seguirão.

Essa encenação contava as desventuras de um fazendeiro generoso quando bêbado e ríspido se sóbrio. A ação foi transposta do interior da Finlândia para o Vale do Paraíba, no Brasil, da década de 1970 e os papéis foram renomeados: Puntila como Sr. Cornélio (Ney Piacentini); Matti, o motorista de Puntila, para Vítor (Rogério Bandeira); Eva, a filha de Puntila, para Vidinha (Helena Albergaria); Attaché para Hélio Savatti (Ricardo Monastero) e assim por diante. Optei por retroagir do final para o começo da peça, sendo que começarei com uma reflexão sobre a derradeira cena em que o proprietário procura se recompor de uma briga por ele provocada justo na festa de casamento de sua filha com o adido diplomático. Antes, pelo efeito da bebedeira, ele havia tentado unir Vidinha ao seu chofer, mas isso não

\footnotetext{
${ }^{80}$ O patrão cordial teve, como fontes de pesquisa, além da obra de Brecht, o livro Raízes do Brasil, de Sérgio Buarque de Holanda (ver nota 46).
} 
aconteceu. Depois da confusão, o arrependido Cornélio afirmaria que iria parar de beber e demitiria (pela segunda vez) uma agricultora comunista.

Enquanto aguardávamos o transporte que nos traria de volta a São Paulo, finda a definitiva apresentação do espetáculo na cidade de Suzano, Rogério Bandeira, olhando para um cão na calçada à saída do galpão onde tínhamos acabado a função, e me disse: "Finalmente descobri o que acontece com o Vítor depois que a peça termina. Lendo seu livro sobre o Kusnet me pus a supor o que teria acontecido ao meu personagem, quando ele vai embora da fazenda. Meu motorista reencontra seu cachorro - lembra que eu falo que já tinha tido um na nossa primeira cena? - e abre um boteco de beira de estrada". "Justo um bar, Bandeira, para quem teve como patrão um 'bebum' que o humilhava?", disse a ele. “Sim, e de vez em quando Seu Cornélio vai até lá encher a cara comigo...”, respondeu Rogério. Repliquei ao meu amigo que apenas havia pouco tempo eu tinha começado a pensar no que poderia acontecer a um personagem depois de ele sair de uma situação no palco. Geralmente eu cogitava sobre o que se passava com um papel antes de ele entrar em cena, como um aquecimento às ações por virem. Considerei, em nossa conversa, que quando saímos para as alas do palco, geralmente abandonamos os personagens e voltamos às nossas individualidades. Ou seja, acontece uma fadiga na sustentação do que é figurado, como se aquilo que arquitetamos imaginariamente se desfizesse e, assim, nos reacomodamos à norma cognitiva pessoal. Se tal explicação fizer sentido, podemos afirmar que projetar ser, o mais continuamente possível, o que não se é, pretender diferenciar-se de si é trabalhoso e demanda exercitar constantemente a faculdade de abstração.

Ainda que descansemos nas coxias, é preciso sempre reenredar-se à ficção. Não menos importante do que essa dispersão inevitável é a retomada da ficção. De acordo com tais ideias, em $O$ patrão cordial, ao deixar o palco, depois de me desconcentrar um tanto, buscava voltar à órbita da história fazendo-me perguntas nos bastidores: "Onde foi mesmo que parei, o que aconteceu quando deixei o espaço cênico? Ah, sim, acabei de colocar os meus empregados em seus devidos lugares. Pensam que só porque eu bebi um pouquinho, vou permitir que a minha fazenda se transforme em uma república de anarquistas. Agora tenho que me preocupar com o casamento da minha filha e fazer sala para o seu noivo. Um sujeito elegante que não é nada disso que dizem dele. Fala-me de vinhos franceses e seria melhor que eu aprendesse com ele alguma coisa sobre uvas e safras. Vai que eu dou uma bola fora diante dos convidados na festa...". Era mais ou menos assim que o indivíduo ator retornava ao seu papel, mesmo fora de cena. 
Ricardo Monastero, que ouvia a conversa entre mim e Bandeira, comentou: "Que importância tem saber o que acontece com um personagem depois que uma peça já terminou?". Eu disse a ele: “É só mais um exercício de imaginação, dentro daquela ideia do Stanislavski de que ela é um músculo treinável. Sempre que pudermos, por que não completarmos o que a dramaturgia não exibe. O que nos custa, mesmo que nunca mais voltemos a fazer essa obra?". Acredito que, se não estimularmos constantemente a nossa capacidade de invenção, corremos o risco de ela nos escapar quando precisarmos.

De volta à peça, complexa e multifocal era a cena final dessa nossa versão de $O$ senhor Puntila e, porque nervosa e agitada, solicitava-me calma. Como alcançá-la vivendo cada uma de suas camadas? Quanto maiores as nossas responsabilidades de representadores, mais elas nos pedem tranquilidade. A ansiedade é uma das maiores inimigas da atuação e um dos remédios para contê-la pode ser a percepção sobre as particularidades que compõem uma ação.

O episódio ora discutido dizia respeito a uma recomposição da ordem, após os escândalos acontecidos durante a festa de casamento de Vidinha com Hélio (a filha de Cornélio e o seu noivo diplomata), da qual o dono da casa tinha expulso os convidados a chutes e xingamentos, incluindo um ministro e a alta sociedade da região próxima à casa da fazenda.

Mas o que teria eu que fazer para evitar entrar em cena esquecendo da tensão que aconteceria lá na frente? Cumprir parcela por parcela das preocupações de Cornélio na situação em que ele se encontrava naqueles momentos. Nos quinze passos que dava até me sentar, minha atribuição era a de lembrar o que tinha acontecido na noite anterior, cuja bebedeira fora maior que as costumeiras. Eu surtara com a frivolidade do meu futuro genro e estaria com dor de cabeça pelo exagero alcóolico e, sem chegar a resolver a representação da ressaca, ao menos resistia às formas conhecidas como gemidos e lamúrias.

Cornélio poderia pensar em uma visita que ele havia recebido do Capitão do Quartel (apenas citada no texto, não visível em cena), fato que em seguida ele citaria em um embaraço com a empregada Maria Rosa (Daniela Castelini). Ou seja, buscava me ver (como personagem) diante do oficial do Exército ouvindo as ameaças desse Capitão, de que eu não poderia manter uma subversiva trabalhando em meus domínios, pois sofreria o boicote da suspensão da compra da minha produção de leite pelo Batalhão do distrito. De maneira que, quando me deparasse com o problema da trabalhadora comunista, eu teria em mente a anterior pressão exercida pelo militar (não aparente no palco), o que me forçaria a demiti-la. 
Decidido a parar de beber, em virtude das generosidades concedidas sob o efeito etílico, eu impunha aos meus empregados que trouxessem toda a minha adega para destruí-la. Nisso chegava Maria Rosa com seus filhos, em seguida o motorista Vítor, juntando-se a eles Ina e Descalcinho ${ }^{81}$ que voltavam com as garrafas da adega. Cindida minha atenção, teria que separar: como mandaria embora aquela mãe esquerdista; responder à interferência do motorista e coordenar o retorno dos funcionários do porão com os engradados.

Se em 2012, quando estávamos nos ensaios abertos da peça, cedia ao engano de reagir rápido aos quatro interlocutores de Cornélio nessa cena, como quem demonstra lepidez interpretativa, ao longo do nosso aprimoramento a direção asseverou que a perícia estaria em abordar cada uma das demandas em tempos-rítmicos únicos. Falsear à comunista demissionária que eu não tinha outra alternativa senão mandá-la embora, pois até os generais exigiam sua saída; vociferar reservadamente contra Vítor, acusando-o de estar mancomunado com a bolchevique; e impor aos empregados Ina e Descalcinho a destruição do meu estoque de garrafas. A escalada nessa sequência, rumo a um ápice corrosivo, estaria sendo fermentada e, justo por isso, seus segmentos haveriam de ser autônomos, justapondo-se em direção ao imprevisto. Os giros propulsores do estrago iminente ao redor do patrão que logo exasperaria sua cordialidade, prescreviam restringir-se às singularidades núcleo a núcleo. Não antever que a governanta largaria as bebidas janela abaixo, por minha própria determinação, impunha que eu fizesse da ação precedente - a entrega do dinheiro a Maria Rosa pelo acerto - um gesto que teria que ir até o seu fim e nunca uma espera artificial, do gênero: "Vou enrolar um pouco aqui ao passar a grana para a Daniela (Maria Rosa) até a Adriana (Ina) ${ }^{82}$ levantar o braço e então eu a interrompo...”. Este seria o raciocínio de fora, em contraposição ao interno, cujo pensamento talvez fosse: "Toma mulher, nota por nota, conforme prometi cumprir a lei e assim estamos quites sem que eu nada fique devendo a você...”. E, numa esgueirada para checar se a minha ordem para acabar com todas as minhas bebidas estava sendo cumprida, entrevia o formato e o rótulo de uma valiosa garrafa prestes a se espatifar, impulsionando-me

\footnotetext{
${ }^{81}$ Descalcinho, personagem interpretado por Carlos Escher, era um jovem agregado à família Cornélio na fazenda. Criação da dramaturgia de Sérgio de Carvalho sobre a obra de Brecht.

${ }^{82} \mathrm{Na}$ segunda montagem de $O$ patrão cordial, o elenco era composto por: Adriana Mendonça, Álvaro Franco, Carlos Escher, Daniela Casteline, Helena Albergaria, Ney Piacentini, Ricardo Monastero e Rogério Bandeira. Na primeira montagem: Adriana Mendonça, Carlos Escher, Helena Albergaria, Ney Piacentini, Renan Rovida, Ricardo Monastero, Rogério Bandeira e Rony Koren. O cenário e os figurinos foram de Cássio Brasil; iluminação de Melissa Guimarães, produção de João Pissarra, assistência de direção e dramaturgia de Paula Bellaguarda e Sara de Mello Neiva, direção musical e composição de Martin Eikmeier, execução musical de Alessandro Ferreira, Cau Karam, Francisco Andrade e Martin Eikmeier, cenotecnia de Waldomiro Paes, desenhos do programa e cartaz de Ricardo Bezerra, diagramação e arte gráfica de Pedro Penafiel, assistência da remontagem de Érika Rocha e encenação e dramaturgia de Sérgio de Carvalho.
} 
para no ar interromper a intenção de Ina. Para tanto, procurei adotar o máximo de atenção em dar fim ao pagamento a Maria Rosa como um meio para desautomatizar aquele instante crucial. Nele, eu recairia com o argumento de que iria demonstrar o meu controle sobre a bebida dando só um golinho. Era então que me enroscaria numa miríade de afagos e agressões aos outros, rasgando o que até então vinha se mantendo separado: sobriedade cortante e bebedeira sentimental.

Nesta hora, misturava sorrisos nervosos com grosserias afetivas, o que me levaria a um delírio de propor fazermos uma montanha com os móveis da casa ${ }^{83}$, na qual subiríamos eu e o chofer para contemplar o vale, comigo me derramando sobre a descrição da paisagem. Diversamente da maioria, uma das peripécias menos resolvidas dessa encenação era justamente quando meu proprietário propunha erguer um morro em plena sala de estar de sua casa. Não foi uma meia dúzia de vezes que nosso diretor repassou conosco esse trecho buscando dar verossimilhança à improvável ideia do cordial patrão mais do que embriagado. Intrigávamo-nos seja com os motivos pelos quais Cornélio decidia por aquele extravagante arbítrio, seja pela razão de que não dispúnhamos de um mobiliário real, mas sugerido por paletes, a base da cenografia.

Eu via aquilo como um não me deixar abater pela rejeição de Maria Rosa, que havia me deixado com a mão estendida, refutando uma conciliação amigável após ser, mais uma vez, dispensada de seus serviços na fazenda. "Eu não vou me deixar abater, a farra vai continuar...", era um subtexto cabível que promoveria a guinada implausível. Mas De Carvalho não se dava por satisfeito alegando inconsistência no ato de eu propor que subíssemos ao Pico do Itatiaia sem sairmos de dentro da casa. Neste momento, ao me apoiar em Vítor dizendo a ele que a nossa relação era diferente da ingratidão da empregada, vendo que ele e Descalcinho me abandonariam, em minha mandonista desolação, dizia-lhes que fôssemos apreciar a "vista deslumbrante" $", 44$ arrastando os móveis para fazermos com eles uma montanha. Na realidade, a coisa não era imediata e por isso tanto refazíamos aquela cena. Obcecado, meu patrão impunha sua vontade até o chofer arregaçar as mangas e não sem violência, empilhar os objetos de madeira e me oferecer, em um misto de raiva e subserviência: "Pronto seu Cornélio, a montanha é sua" 85 .

\footnotetext{
${ }^{83}$ A cenografia da peça era composta por uma lona no chão e paletes e baús que se transformavam de acordo com as cenas, como na final, em que eram empilhados feito os móveis da casa.

${ }^{84}$ Frase extraída da dramaturgia de Sérgio de Carvalho para $O$ patrão cordial, sobre a obra de Beltolt Brecht $-O$ senhor Puntila e seu criado Matti.

${ }^{85}$ Idem.
} 
Parece-me que tínhamos dois obstáculos: um aparente e o outro não. Como sugerir que paletes e baús seriam o sofá, as cadeiras, o relógio de parede etc., que seriam empilhados como um monte sobre a lona-chão? E o que levaria o agropecuarista a tal atitude? A mim caberia mais essa segunda instância e, em estado alterado etílica e emocionalmente, eu seria capaz daquele absurdo e mais, ao escalar o monte feito das coisas da sala, de cima dele me deslumbraria com a paisagem. O painel se completava com uma música melancólica ${ }^{86}$, composta por Sérgio de Carvalho e Martin Eikmeier, que contrastava com a fúria de Vítor destruindo os móveis e construindo a montanha. Não resolvemos de todo essa questão teatral e, caso continuássemos a apresentar a peça, não estariam descartados reensaios para buscarmos outras saídas para uma transição problemática. Contudo, nesse disfuncional epílogo do personagem, em que um homem chorava admirado de suas próprias posses, após de uma das nossas apresentações, cheguei a ouvir de um espectador que ele enxergava a serra, o rio e a estrada por mim descritos. Quero dizer, as dificuldades intrínsecas àquele trecho não chegavam a obstruir o transcorrer da cena.

Entre as possibilidades para manter o frescor do meu Cornélio na última temporada da peça, foi recorrente o recurso de me imaginar em situações paralelas às ações propriamente ditas do espetáculo. Para evitar o lugar-comum que caracteriza um ator entrando no palco simulando surpresa, procurava em pensamentos, antes de entrar em cena, visualizar a paisagem no entorno da casa do meu personagem como se eu estivesse atrás de Vidinha, sumida justo na festa do seu casamento. Por uma associação de imagens, o pátio que eu avistava pela janela do prédio em que a nossa peça era mostrada seria o da minha residência, um anexo ao setor que ocupávamos seria o depósito da fazenda e assim, mesmo estacionado nas coxias, eu estaria em busca da minha filha. O subtexto decorrente disso seria: "Onde ela se meteu? Vai me deixar na mão essa sem-vergonha? Será que ela se escondeu no curral?”. E entrava em cena vendo-a com uma garrafa de bebida nas mãos, nos braços de Descalcinho. "Enchendo a cara, a desgraçada...", dizia a mim mesmo em silêncio. Eu evitava pisar sobre a lona vazio de inquietações que supostamente antecediam aquele momento entre pai e filha.

E ao perceber o baixo nível do líquido dentro da garrafa, deduzia que normal ela não estava. Então, esquecendo que eu mesmo era um beberrão, chamava-a de volta à realidade, xingando-a de "Escapista!". E não passou desapercebido da direção uma minha inserção no meio da dança dos convidados em que, ao pegar um copo e a concha do ponche, bebia na

\footnotetext{
86 "O velho ator sobe a ribalta/ Num gesto de todos se afasta/ Sozinho num palco ideal/ Sozinho num palco ideal/ Eu tinha paixão do arruído/ Do cartaz do foguete de lágrimas." (Esses dois últimos versos foram retirados de Memórias póstumas de Brás Cubas, de Machado de Assis.)
} 
própria concha enquanto com o olhar dava uma panorâmica no ambiente do salão. Sérgio de Carvalho aprovou o gesto, vendo naquele meu olhar, por detrás da forma convexa do objeto que tapava a maior parte do meu rosto, a preocupação do fazendeiro com os custos da festa, simultânea ao proveito gaiato que o patrão tirava bebendo dos seus próprios gastos. No entanto, eram grandes as chances de isso se tornar um artifício de ator, caso todas as noites eu não elaborasse mentalmente os reais porquês daquela atitude imprópria.

Saliento que o casamento descambaria em escândalo, sendo imperativo que Cornélio vivenciasse cada passo que o levaria a uma explosão frente aos presentes na festa. Para isso, eu teria que graduar a minha irritação por causa do comportamento do noivo. Primeiro eu estranharia o modo exagerado como aquele diplomata dançava no salão. Depois, quando meu amigo Frederico, o juiz da cidade, contava-me uma piada para aliviar o recinto e o noivo não a entendia forçando um riso histérico, eu perderia a paciência, batendo na bandeja de bebidas e partindo para cima dele. Revisamos muitas vezes essa briga entre mim e aquele diplomata. Um bate-boca não se faz com os dueladores se estrebuchando desde o seu começo. Isso seria começar a cena pelo seu final. Tínhamos que pouco a pouco perder a paciência um com o outro. Eu ordenava que ele abandonasse a minha casa chamando-o de "Seu cupim de fraque, eu não vou deixar você roer minha fazenda e o meu sangue...”. Ele não obedecia, comentando: "Senhores, peço a vocês encarecidamente que ignorem este incidente que está ocorrendo" ${ }^{\prime 7}$. Os seus atenuantes faziam aumentar minha irritação e, frase a frase, desembocaríamos comigo o arrastando para fora e torcendo-lhe o nariz.

Expulso o almofadinha e, com ele, a elite local, eu decidia entregar minha filha ao motorista, insistindo em continuar a festa com os empregados. "Somos todos iguais!" 88 , eu afirmava alcoolizado. Diante da relutância de Vítor, Vidinha (não menos alterada) armava um torto rito de pedido de casamento ao chofer e eu me emocionava com o enlace de minha filha. Todavia nosso diretor constatou que em certas passagens da peça o elenco, prevendo as risadas na plateia, armava-se para atingir o efeito cômico, ficando a vivência das situações a reboque, como neste ponto com ela pedindo a mão do motorista. Logo após suas românticas palavras, eu me aproximava dos dois exclamando baixo e chorando: “Lindo, Vivi!'. Não era improvável que o público risse do ríspido patrão agora meigo e sentimental e com voz

\footnotetext{
${ }^{87}$ Na tradução de Millôr Fernandes a frase é: "[...] um gafanhoto de fraque [...]”. BRECHT, Bertolt. O Senhor Puntila e seu criado Matti. Rio de Janeiro: Paz e Terra, 1993, p. 86. "Seu cupim de fraque..." faz parte da reelaboração dramatúrgica de Sérgio de Carvalho a partir da obra de Brecht.

${ }^{88}$ Essas palavras não fazem parte da tradução de Millôr Fernandes e foram colocadas por Sérgio de Carvalho na nossa versão. No texto de Brecht, consta apenas: "E por que na cozinha? O noivado de vocês ainda não foi festejado...”. BRECHT, Bertolt. O senhor Puntila e seu criado Matti. Rio de Janeiro: Paz e Terra, 1993, p. 89.
} 
adocicada. Nenhum problema com o público se divertindo, desde que isso viesse das reais trocas entre os papéis e não dos truques dos atores.

Na trama, as alegações de Vítor de que a noiva não suportaria as condições e os costumes entre os pobres levariam minha filha a propor um teste em que ela comprovaria ser capaz de viver casada com um empregado em um lar modesto. Diante das provas a que a noiva se submeteria de como receber o marido depois de um dia exaustivo de trabalho, tirar as botas do esposo, costurar uma meia suja dele etc., eu me modifiquei ao longo da temporada de uma agitação contínua para apenas assistir o desconcertante de uma mulher rica se fazendo passar por dona de casa. Diviso que, caso não me cuidasse, exageraria nas caras e bocas reativas, interferindo em uma cena em que eu era um espectador interno, ainda que, quando citado bêbado, me divertia concordando que eu era um execrável patrão.

$\mathrm{O}$ mesmo se pode dizer do bizarro número que minha filha me faria, depois do malogro da união entre ela e o chofer. Quando eu menos esperava, Vivi voltava à sala insinuando um strip-tease cantando uma paródia de "My heart belongs to daddy" 89 , na qual ela declarava ser do pai o seu coração. Ver minha filha se comportando daquela maneira me causava prostração, sem que eu quisesse vê-la dançando, esfregando a blusa entre as pernas e mostrando os seios no colo de Descalcinho. O meu desespero viria da impotência paternal que se dava conta do estrago que atingira o que restara da sua família. A decadência filial doía mais que o copo que ela lançava contra mim e nada poderia ser feito a não ser admitir a minha debacle como pai. Quanto mais histérica uma cena, mais dentro dos personagens podemos ficar, sem acentuar o que já é o suficiente.

Nessa cronologia invertida da peça, no meu penúltimo entremeio, eu aguardava num vestíbulo lateral ao palco o ponto de reentrar na peça. Nele eu avisaria meu futuro genro que o Ministro, seu principal convidado, havia chegado ao casamento. De modo que aproveitava o tempo fora de cena para imaginar os preâmbulos da ação seguinte e voltava meus pensamentos para o que seria o portal da minha propriedade, local em que chegaria um carro oficial.

Pensava também que, ao receber um telefonema no qual me avisavam do desembarque de uma autoridade federal, sairia à procura do meu motorista para que ele fosse à cidade se inteirar sobre a recepção do Ministro, o que estava me deixando inseguro, já que eu não era o mais elegante dos donos de fazendas daquelas bandas e não sabia como exatamente deveria me comportar em uma ocasião como aquela. Indo atrás do meu chofer, apanhava-o na

\footnotetext{
${ }^{89}$ Música de Cole Porter cantada por Marilyn Monroe.
} 
presença de quatro mulheres, em pleno bate-papo, o que me freava repentinamente. Assim encontrava as trabalhadoras da cidade que eu havia pedido em casamento em uma bebedeira de dias atrás, mostrada em outra parte da peça. Era apenas nesse momento que eu reentrava em cena e tudo o que relatei antes eram os meus preparativos. Note-se que também aqui lançava mão do recurso de me preencher com possíveis acontecimentos que precediam a ação propriamente dita. Seguindo essa ideia, punha-me ainda a olhar para os objetos nos bastidores, que na realidade eram bolsas, roupas e equipamentos da equipe do nosso grupo, embora eu procurasse vê-los como mantimentos que seriam usados na festa que iria acontecer na residência de Cornélio, como se ali fosse a dispensa em que estavam guardadas as comidas e bebidas que seriam servidas no casamento. O que me deixava um tanto mal-humorado, porque quem pagaria aquela abundância seria eu mesmo. Por conseguinte, ao ir cobrar do motorista o porquê de tantas caixas de champanha no depósito, via o empregado divertindo-se com aquelas mulheres no gramado.

Descrevi os antecedentes por mim figurados para destacar que fazia um movimento de me afastar ao máximo da previsibilidade de que as encontraria em meus domínios. De maneira que, quando perguntasse a Vítor - "Quem são essas?"90 -, como constava na dramaturgia, estaria mais próximo de realmente me surpreender. A afirmação irônica do chofer de que eram minhas amigas acendia em mim uma faísca de recordação, como: "Já vi essas mulheres em algum lugar...”. Ao delas ouvir que eram minhas noivas, eu pensava: "Meu Deus, o que foi que eu aprontei para que estejam no meu portão dizendo que eu as pedi em casamento...". Aos poucos, eu as ia reconhecendo e, simultaneamente, projetava o vexame que aquelas donzelas iriam me fazer passar diante da burguesia regional. Ao ecoar em mim que todos iriam rir da minha cara com comentários jocosos - "Que porre o Cornélio entornou para chamar aqui essas coitadas?”, ou "O velho acha que dá conta dessa mulherada toda?" reagia que tinha que expulsá-las antes que os verdadeiros convidados começassem a chegar.

E um dispositivo de transformar objetos e pessoas reais em outros que tivessem relação com o universo do espetáculo, surgiu-me mais nitidamente nessa nossa temporada final da peça, quando, em uma tarde, tive que atender um telefonema sobre um problema externo a $O$ patrão cordial. Normalmente, prefiro não olhar para o aparelho celular, a fim de evitar surpresas que me tirem da concentração no preparo para atuar ou ensaiar. O problema são as exceções. Cerca de duas horas antes de começarmos a sessão, envolvi-me em uma

\footnotetext{
${ }^{90}$ Segundo Millôr Fernandes: “Quem é essa gente aí?”. BRECHT, Bertolt. O Senhor Puntila e seu criado Matti. Rio de Janeiro: Paz e Terra, 1993, p. 86. "Quem são essas?" foi como Sérgio de Carvalho a transcreveu para a cena.
} 
conversa em que fui criticado por ter tomado a iniciativa de promover o mesmo II Congresso Brasileiro de Teatro (comentado anteriormente em $O$ círculo de giz caucasiano) e, devido às alterações no calendário das apresentações do Repertório 2104 da Companhia do Latão, não iria comparecer ao encontro que eu havia incentivado para que acontecesse.

Importa menos saber se eu tinha ou não responsabilidade sobre os compromissos em discussão do que quanto fiquei preocupado a ponto de não conseguir tirar aquilo da minha cabeça. Com a proximidade do horário da apresentação, em que costumava me vestir com parte do figurino e fazer um alongamento sobre a lona, ocorreu-me transferir para o meu personagem o embaraço: e se ele tivesse marcado uma reunião da associação dos fazendeiros da região e depois tivesse avisado que iria faltar? A cada sentença do telefonema que me voltava à lembrança, tratava-a como se fosse chamada dos membros da organização dos agropecuaristas me cobrando a presença: "Bonito, hein? Marca a reunião e desaparece? Está pensando que é o rei da paróquia, Cornélio?”. Neste caso, diferentemente do que descrevi em "Um desvio atoral", no subcapítulo anterior, percebi que diminuía a tensão causada por uma preocupação da minha vida fora do ambiente da peça e cheguei a me divertir derivando que o meu patrão, pirracento que era, sentia um gosto em deixar os associados na mão. Ampliando a solução encontrada naquela tarde, recorri ao mesmo expediente em outras ocasiões em que fatos externos perturbaram meu envolvimento com a história encenada. Se ruídos de motores de automóveis invadiam a sala que não possuía isolamento acústico, poderiam ser dos carros que chegavam ou passavam pela minha fazenda. As luzes de aparelhos de telefonia móvel que se acendiam durante o andamento da peça, iriam se passar pelos vagalumes rondando a paisagem e assim por diante.

Quanto mais permanecia ausente do palco, por meu personagem não presenciar as cenas que aproximavam sua filha do chofer, continuava me comportando como Cornélio fora do estrado. Se antes, costumeiramente, quando estava nas coxias, entregava-me aos meus devaneios pessoais, aleatórios e incontroláveis, mudei de atitude, passando a ter esses momentos que estamos apenas conosco, em um camarim ou em um canto apartado do espaço teatral como um prolongamento da peça. Se temos que ficar em silêncio para não atrapalhar o correr da apresentação, em um rito que pouco existe em outras ocupações humanas, por que não continuar em ação para além dos limites dos cenários?

$\mathrm{Na}$ obra, havia uma passagem em que eu entrava com o que sugeria ser um vestido de noiva, para interpelar minha filha. Isso acontecia depois de eu ter saído esbravejando contra os meus empregados e, ao aguardar o episódio em que expulsaria minhas ex-futuras noivas, punha-me a especular que depois de dias sem dormir, bebendo muito, terminava dormindo 
sem sequer tirar o terno que vestia. Naturalmente que eu, o ator, não dormia realmente, mas fazia de conta que meu personagem se entregava ao sono e, quando acordava, havia ao meu lado o que parecia ser o vestido que estava sendo costurado para Vidinha. Eu mesmo havia contrarregrado o adereço, de modo a tê-lo em mãos quando dele precisasse, coisa comum em qualquer representação teatral em que temos que preparar nossos apetrechos para deles fazermos uso. No entanto, após fechar os olhos, entrava no que supunha ser Cornélio sonhando com uma debandada do seu gado estrada afora e, ao acordar, deparava-me com o corte do tecido branco com um tule por cima do cetim. "Mas o que é isto?" Pensava como se estivesse meio sonolento. "Quem deixou isso aqui e o que significa?" Lentamente, ia atinando ser aquilo a roupa do casamento de Vivi e que talvez fosse uma provocação da minha filha deixá-lo ali, já que eu poderia ser um pai que brigava sempre com ela. "Quer me perturbar, a desgraçada?” E rosnava, como quem mal dorme depois de uma bebedeira: "Mas eu vou atrás dessa moça e ensinar a ela como se obedece a um pai...”, para então entrar no tablado com a vestimenta nas mãos e me deparar com ela em outro problema. Por alguns segundos lhe apontava o figurino como quem supostamente cobrasse: "O que isto estava fazendo ao lado da minha poltrona?", como uma ação interna e, à medida que ela me lançasse outro assunto, entrava em relação com suas questões, mantendo uma desconfiança não verbalmente expressada e mostrando-lhe a roupa que trazia nas mãos. Replicava esse exercício imaginário para me desabituar do que eu ouvia em todas as notas dos meus colegas.

Abro parênteses para falar de um singular progresso, adquirido durante as exibições públicas dessa nossa versão de $O$ senhor Puntila. Ou me engano ou nós, atores, quando temos trocas rápidas de roupas entre os quadros de um espetáculo, involuntariamente nos desconectamos dos nossos personagens em meio às urgências de nos desfazermos de camisas e calças para vestirmos outros figurinos. Percebi que, ao ter que rapidamente me recompor atrás dos paletes do cenário, ao invés de me ver como o ator se preocupando se iria conseguir se vestir a tempo, passei a perceber que era o personagem quem se arrumava, enquanto ouvia a conversa entre seus empregados. Desse modo, reuni, em uma atitude, o que poderia ser um exclusivo problema técnico a uma atenção aos comentários feitos pela minha governanta Ina, o motorista Vítor e Chalton (um trabalhador de serviços gerais). Os três estavam falando de mim e eu os escutava enquanto manipulava botões, camisa, suspensórios, colete, paletó, gravata e chapéu.

Aproveitava o exíguo espaço atrás da cena para me esconder deles e a cada frase que diziam a meu respeito, vestindo-me reagia em pensamentos que iam de "Esses desgraçados estão falando mal de mim?"; passando por "Dou emprego à canalhada toda para ficarem 
reclamando às minhas costas?"; até chegar em: “Ah, mas vão se ver comigo e é para já!”. A incumbência extraficcional de ter que primeiro reabotoar a camisa desfeita na cena anterior, subir aos ombros os suspensórios, pôr a gravata e, em seguida, o colete para só então entrar no paletó, completando com o terno e o chapéu, em um curto tempo, foi inserida no personagem como que espreitando as maledicências de seus funcionários sobre ele mesmo. Uma vez que Cornélio, passada a embriaguez, voltava ao seu autoritarismo sem freios, havia uma conjuminação fora/dentro da cena, unindo duas faces: a técnica e a imaginária. Consequentemente, ao terminar de me arrumar oculto ao trio que conversava sobre a falta de contratos de trabalho, rumava até eles dizendo: "Vagabundos, o que é essa assembleia aqui?"91.

Não obstante, havia algo malfeito nessa sequência. Em mais um "colapso de sobriedade" ${ }^{92}$, meu personagem ia para cima do motorista, intimando-o a lhe entregar o seu casaco. Hoje percebo que fazia uma transição menos realista do que mecânica, dado que o meu conhecimento antecipado como ator era o que fazia o roteiro seguir, sem que o personagem tivesse motivos suficientes para desconfiar que seu subalterno o estaria enganando. No pico daquele trecho, depois de arrancar o paletó de Vítor, eu encontrava em um de seus bolsos a minha carteira de dinheiro e o acusava de ladrão, sendo que na primeira cena da peça eu pedira a ele para que a guardasse - "antes que eu amoleça" ${ }^{\text {"93 }}$, tornando-o meu cúmplice na prevenção das bondades que eu cometia quando bêbado e das quais pudesse depois me arrepender. A ressalva atoral é a de que, do ponto de vista de Cornélio, não engendrei motivos suficientes para ir de encontro ao meu empregado. Depois de desfazer a reuniãozinha entre eles, mandando Chalton embora e afirmando que não iria assinar a carteira de trabalho de ninguém, voltava-me ao chofer dizendo: “[...] deixa eu ver este paletó"94. E o arrancava do seu corpo sem saber ao certo o porquê de tal ofensa. Tenho para mim que, quando vamos insultar alguém em ato teatral, o atavismo das ações nos leva a elas, antes de formularmos as razões do nosso irracionalismo. Sequer um lampejo vinha-me à cabeça que me fizesse sentir a falta da minha carteira. Ou que eu estivesse encenando uma farsa diante deles por estar ciente de que lembrava ter dado a ele a guarda do meu dinheiro e naquele instante mentia que ele me roubara. Faltou um engano interno, ou algo que o valha, para dar vazão ao brusco ataque em direção ao motorista. Ao encontrar a carteira, descarregava no

\footnotetext{
${ }^{91}$ Frases inseridas na nossa montagem pelas mãos de Sérgio de Carvalho.

92 Idem.

93 Idem.

94 Idem.
} 
chofer a minha fúria e, no instante em que Vítor ia me responder que fora eu mesmo que a entregara a ele, eu o xingava de "Ladrão!".

$\mathrm{Na}$ cena do banheiro, tínhamos nosso maior problema em grupo. No enredo, minha filha e o motorista tramavam para fazer com que o diplomata Hélio desistisse do noivado, com os dois se fechando em um sanitário como se fizessem sexo, fingindo gritinhos e gemidos, porém simulavam jogar baralho. A dificuldade para o elenco era o fluxo dos curtos diálogos em meio à simultaneidade das ações. A dramaturgia desse segmento estabelecia ao redor da dupla Vidinha-Vítor mais dois veios formados pelos empregados Ina e Descalcinho e por Hélio e Cornélio, sendo que os três pares se misturavam no decorrer da situação. Haveríamos de dominar o entrecortado jogo das falas-atos e dar vida a ele. Mas a sobreposição da movimentação dos personagens fazia com que sempre tivéssemos que reensaiar, levando também em consideração os aprefeiçoamentos da direção de uma sequência que muito ecoava nas plateias. Eu passei a me integrar melhor à multidimensionalidade daquela cena quando percebi que eu teria, sobretudo, que ouvir, de forma gradativa, o que vinha dos demais papéis. Se, como fazia no começo do quadro, eu estivesse reagindo desde o início sabendo aonde o conflito ia chegar, a ação estaria fadada ao engodo teatral. Foi quando passei a promover uma escuta progressiva que melhorei meu envolvimento com o episódio. Primeiro ouvindo os barulhinhos (gemidos) que vinham do banheiro sem os identificar ao certo se eles eram de animais ou de gente. Em seguida, ao reconhecer que eram sim de pessoas, não distinguia quem estava sussurrando exatamente o quê. Depois passava a desconfiar que era a voz da minha filha murmurando e que deveria estar na companhia de um homem. Era quando atinava que algo comprometedor estava se passando. A atenção aos detalhes da situação é o que daria vivacidade ao que se passava entre nós e faria da comicidade não uma meta, mas uma consequência das articulações na cena.

Contratando gente no mercado para a minha fazenda na quinta parte da peça, via-me, a certa altura, novamente dividido em mais de um foco. Foi quando meu diretor me disse: "O que é este pezinho virado meio para trás?”. Naquele momento eu estava de frente para a garçonete do bar do local, sendo que logo seguida teria que me dirigir ao chofer que negociava com os trabalhadores ali disponíveis. Sequer havia reparado que minha perna esquerda já estava voltada à marca seguinte. Ao me perceber daquele modo, respondi que como o próximo fragmento seria na direção em que meu pé precipitadamente girava, involuntariamente me adiantava ao instante seguinte. Sérgio comentou que aquele era um raciocínio do intérprete se auto-orientando e não do personagem que passava uma cantada na garçonete. "Conclua o que Cornélio começou e depois, com calma, vá ao encontro do seu 
motorista." Esse desacerto é similar ao que relatei sobre a última cena da peça (p. 131-132): se acontecer de termos a atenção fracionada em diferentes focos, contracenando concomitantemente com vários parceiros, é melhor evitar presteza demasiada e particularizar cada parte que compõe o conjunto das ações cênicas.

$\mathrm{Na}$ dramaturgia da Companhia do Latão, ocorrem sínteses que provocam saltos, requererendo do elenco mudanças abruptas nos comportamentos de suas figuras. Interrupções com cortes temporais que cindem as linearidades. Todavia, a meu ver, temos que não simplesmente pular agilmente de uma fração de tempo a outra, porém sermos conscientes da autonomia das partes que dão sentido ao todo. Se é vário o espaço-tempo em um tecido dramático, cabe aos intérpretes se aterem aos pedaços que possam reunir o que foi segmentado pela encenação. Digo isso porque em nosso teatro-épico dialético não são raras as concisões em que breves narrativas se mesclam a imagens sucintas e/ou curtos diálogos, o que, em alguns casos, fornece um caráter fragmentário à estética latoniana. Para que essa opção não recaia em formalismos, é solicitado aos atores e músicos o máximo de cuidado com cada uma das células cênicas, integrantes de um organismo maior que, quanto mais bem executadas, melhor substância darão aos corpos das obras. Acrescento a esse comentário o aspecto ensaístico dos processos do grupo, nos quais optávamos por não darmos por acabados os nossos trabalhos, renovando-os continuamente, o que, por sua vez, imprime nas montagens a exposição aos espectadores do funcionamento teatral. Isso porque, para nós, expor as regras do jogo horizontaliza a relação com os espectadores sem deixar de encantá-los.

Digno de nota foi um acaso entre mim e o diretor que, por ser também dramaturgo, costuma atualizar tanto as movimentações quanto os textos, em um permanente aprimoramento estilístico e temático das nossas peças. Em O patrão cordial, havia um diálogo entre Cornélio e Maria Rosa, no qual o proprietário (bêbado) perguntava à empregada por que ele (sóbrio) a tinha demitido. Sérgio me pediu para que eu incluísse algumas palavras a mais naquele reencontro: "A terra da Esperança nunca mais vai sair debaixo dos pezinhos deles. E eu vou mandar reabrir a escola"95. Elas seriam relativas à situação de descaso em que se encontravam a camponesa e seus filhos que, depois de terem sido dispensados pelo dono da fazenda, ficaram privados de um lugar para viver e da escola que havia sido fechada por ordem do mesmo patrão que agora mudava de ideia. Atendi imediatamente àquele simples

\footnotetext{
95 Trecho adaptado para a nossa montagem por Sérgio de Carvalho (Esperança é o nome da fazenda de Cornélio).
} 
pedido e, pelo fato de ter recebido as frases pela voz do dramaturgo e não por escrito, imediatamente me vieram imagens de pés pisando a terra e de uma escola rural.

Percebi que, sem ler as palavras, foi-me natural imaginar o que dizia sem ter que recordar da disposição das letras em uma folha de papel. Ou seja, não seria melhor, ao invés de termos que memorizar, apenas ouvirmos e aos poucos assimilarmos os conteúdos, abreviando assim a etapa de primeiro nos lembrarmos da ordem das palavras no texto para somente depois darmos vida a elas? Ciente de que estou levantando uma hipótese inusitada, sugiro ao menos que os colegas tentem, se é que já não o fizeram, não mais lidar com arquivos de computadores ou cópias grampeadas ou espiraladas de textos, e sim que façamos um trabalho em conjunto com os assistentes de direção, na impossibilidade de termos o tempo necessário para tal com os diretores, para que nos repassem oralmente a literatura dramática escutando-a e a ensaiando sem o uso dos suportes que contêm os textos escritos. Trata-se de uma proposta de avançar sobre a análise ativa ${ }^{96}$, liberando os intérpretes de decorar seus trechos, saltando diretamente para a elaboração das imagens e sentidos das palavras. $\mathrm{O}$ acaso acima descrito carece de confirmação, porém creio merecer experimentação, ainda que seja para demonstrar a sua inviabilidade.

Retrocedendo ao quarto quadro da peça, discorro sobre o primeiro dos dois encontros de Cornélio com suas quatro futuras noivas (anterior ao descrito na p. 136). Após brigar com a filha que o impedia de continuar bebendo, meu adicto ganhava a madrugada em busca de álcool e acabava por se envolver com algumas trabalhadoras das redondezas. Em uma rodada em que mais ouvia delas suas condições de vida, posto que quando bêbado eu me interessava pelos outros, a cada ensaio e apresentação fui prestando mais e mais atenção no que elas tinham a me dizer. Se no início desse projeto ficava preocupado com o que eu teria que fazer diante delas, com o tempo passei a me deter no que aquelas damas tinham a me dizer. Segundo o princípio de que ouvir os que contracenam conosco precede nossas ações, fui perdendo a necessidade de enfiar "caquinhos" no meio dos relatos, priorizando recepções internas não verbalizadas e lutando contra manifestá-las por expressões faciais.

Lembro-me de que a atriz e diretora Helena Ignez, após assistir a $O$ patrão cordial, fez-me um comentário sobre minhas caras e bocas. Apesar de Ignez provavelmente me ter elogiado, fiquei constrangido na presença dela e fui para casa falando a mim mesmo: "Não

\footnotetext{
96 Análise ativa ou análise em ação ou análise em pé: ideia concebida por Stanislavski, trata-se de um procedimento de se conhecer uma dramaturgia através de improvisações programadas que levem os atores a compreenderem as situações dramáticas sem o uso do texto teatral. Também conhecido por Método das Ações Físicas (ver nota 33).
} 
tem jeito, você é mesmo um careteiro, que sempre suja suas atuações". Contrariando meu autodeterminismo, passei a conter minhas caricaturas, policiando-me para interiorizar os efeitos da bebida. O substrato dessa luta contra o que é demonstrativo, que se traduz na redundância entre o que se pensa e o que faz com o corpo (incluindo o rosto) e a voz, foi um controle para não exagerar com as faces enquanto elas me contavam sobre suas vidas, tampouco emitir sonzinhos dispensáveis, mas, sobremaneira, entender o que as moças me diziam. Nesse sentido poderia surgir algo distinto, como o contraste entre suas sofridas narrativas (mas expressadas sem autocomiseração) e o meu entusiasmo etílico. Não seria forçando ao público com um pensamento como: "Vejam, vocês sentados na plateia, como estou me deliciando com a dura realidade destas trabalhadoras...”, e sim me deixar encantar pela singularidade de seus problemas. Cabe dizer que três atores (que na última temporada foram dois $)^{97}$ faziam as personagens femininas, em um formato que driblava os clichês de homens representando mulheres no teatro, justamente pela sinceridade atuativa. Eu me dirigia principalmente às mãos de Rony Koren, aos olhos de Renan Rovida e às nádegas de Carlos Escher, o que me despertava ternura e desejo por elas (feitas por atores barbados). Essa atenção dirigida me afastava das tipificações opondo volúpia e a sua contenção, a bebedeira e “os esforços em parecer sóbrio" (ver p. 65).

Como tínhamos, por parte da direção, a recomendação de não nos deixarmos embalar pelas atmosferas criadas por fundos musicais lentos, entendi melhor a noção de tempo-ritmo nessa abordagem de Cornélio. Na contramão de um certo enternecimento da cena, sentia-me excitado pela companhia de quatro mulheres e as pediria em casamento. E não se comete tal impulso sem alguma ebulição interna. Elas tinham suas razões para reclamar da vida e a dramaturgia de Brecht/Carvalho era rica o suficiente para realçar as contradições daquelas prestadoras de serviços seduzidas pelo fazendeiro. Mas nas veias de Cornélio corria a fantasia etílica de noivar com todas elas de uma vez só. Mesclando compreender suas provincianas existências aos meus aflorados desejos, eu irrompia em um apaixonado "Casem comigo!".

Havia sim uma suavidade musical por parte do maestro Eikmeier e seus instrumentistas e, embora meu corpo se mantivesse estático ouvindo-as, por dentro eu estava agitado, o que desarmonizava a sonoridade da atuação. Do que assimilei do termo stanislavskiano, o tempo-ritmo não se refere a uma concordância entre os termos cênicos, como interpretar liricamente quando a iluminação está azulada. Porém diz respeito à pulsação

\footnotetext{
${ }^{97}$ Na primeira temporada, eram Carlos Escher, Renan Rovida, Rony Koren mais Adriana Mendonça que faziam as mulheres. Na segunda, Renan Rovida foi substituído por Daniela Casteline e Rony Koren por Álvaro Franco.
} 
interna dos personagens, segundo aquilo que está acontecendo psicofisicamente com eles. Por exemplo, as impulsões interiores de quando gostamos de alguém são diferentes das de quando desgostamos. O que nem sempre se traduz nas mesmas exteriorizações físicas e, por vezes, acontece justamente o contrário: “[...] tio Vânia. Astrov, Sônia, as três irmãs e outros personagens estão quase sempre tranquilos exteriormente, mas agitados e comovidos por dentro" (STANISLAVSKI, 2009, p. 260).

Avançando, pergunto-me se o que descrevo a seguir tem relação com o florescimento do subconsciente ao qual se referia Stanislavski, ou seria um golpe de intuição em função de um meu envolvimento cada vez maior com o meu Puntila/Cornélio, ou melhor, se foi mero acaso. Na cena dois, em que meu personagem voltava para casa após uma ausência de trêsdias de pescaria e bebedeira, aproximando-me para beijar o rosto de minha filha, Helena Albergaria, intérprete de Vidinha, vinha ao meu encontro para conferir o meu bafo, pois conhecia o pai que tinha. Em uma das apresentações da peça, senti em seu hálito um cheiro adocicado parecido com o de chocolate, o que me causou uma leve repulsa, sem que eu me programasse ou esperasse por aquilo. Como ator, sabia que ela tinha comido um doce, uma vez que eu assistira a cena anterior, na qual Vivi e Hélio (meu futuro genro) ficavam à minha espera. Porém meu personagem tudo ignorava, pois estava fora de controle de tanto beber. Considero esse incidente importante (invisível a todos - elenco e público) por ele ter me conduzido a um contrassenso: do ponto de vista de quem quer continuar se embebedando, o gosto de chocolate pode não ser agradável e até causar rejeição. Tenho a expectativa de que esse frêmito germinou, por segundos apenas, uma reação autônoma do papel, fugidia às minhas convenções atorais. Teria a jornada iniciada em 1997 dialetizado a sensorialidade?

Entretanto, essa mesma parte da peça me impunha outros desafios. Vindos da pescaria, entrávamos na sede da fazenda com meu motorista carregando um baú nas costas, enquanto éramos aguardados por Vivi. Preso à marcação, eu dava menos atenção a ela do que ao instante em que Rogério Bandeira (no papel de Vítor) depositaria a arca no chão. Eu antecipava o perigo das garrafas quebrarem naquele momento, reduzindo a relação ao que ocorria diante dos meus olhos. Se minha filha me dava uma bronca por eu ter ficado três dias fora de casa, responderia a ela e, somente quando ouvisse o som da arca batendo no piso, voltaria-me para o chofer. A preocupação com como e onde exatamente tal ou qual movimento de adereços ou cenários vão ocorrer por vezes nos trai a atenção daquilo que é o fundamental: viver as situações enquanto elas se apresentam diante de nós.

Por outra via, os transtornos causados pelas dificuldades de se lidar com um enorme e pesado artefato de madeira contendo garrafas em seu interior eram propositais (e tiveram 
inspiração chapliniana). Durante a feitura de $O$ patrão cordial, Sérgio de Carvalho enfatizou a importância das ações físicas nas atitudes dos personagens ${ }^{98}$. Se a marca material dessa cena era a instabilidade do baú sobre os ombros do motorista, todos os demais episódios da obra continham seus pontos concretos: empilhar os móveis da casa para fazer uma montanha na sala, torcer o nariz do diplomata e arrastá-lo para fora da casa, tirar as peças de roupa em um strip-tease etc.

Mas o maior entrave dessa volta ao lar acontecia quando eu era impedido de continuar a beber. Depois de uma disputa em que minha filha ordenava a Vítor que subisse o baú para o andar de cima da casa, eu a desobedeceria e o abriria, deliciando-me com o que por dentro era um verdadeiro bar ambulante, com várias marcas de bebidas. Ao insistir em sua repreensão ao pai fechando na minha cara aquele meu tesouro, ela provocava em mim um sentimento trágico: “O filho pródigo volta à casa e nenhum carneiro é morto, nenhum vinho é aberto. Só desprezo e humilhação! Assim me obrigas a voltar para a rua!"99 . Essa passagem, a propósito, era-me imprecisa. Tanto que, certa noite, Sérgio de Carvalho me mostrou algumas fotografias que ele mesmo vinha fazendo do espetáculo e, entre elas, estavam justamente as do instante em que eu clamava aos céus sobre me subtraírem os álcoois. Como os retratos do meu alterado pai foram feitos em diferentes noites, comentei com Sérgio que em uma eu "estava no personagem" e na outra, não. O porquê de uma foto transparecer alheamento e a outra, envolvimento, de acordo com os meus parâmentros, deve-se a que na segunda havia lacunas a serem preenchidas por motivações internas que dessem sustentação à expressão facial e gestual, ao passo que, na fotografia em que me via mais como o fazendeiro, provavelmente implicara-me mais com os problemas do próprio Cornélio.

Por exemplo, quando pensava apenas, sem a emissão de palavras, que "Estão levando a minha capela para longe de mim, por que meu Deus, por quê? O que fiz para merecer tamanho castigo? Que crueldade com um pobre ser humano que só tem suas santas garrafas como únicas e fiéis seguidoras...”, em uma mistura de fígado e oração, prepararia, quem sabe, a eclosão textual da citação da Bíblia, proposta pela dramaturgia. Entre recuos e avanços, entre mim e Helena Albergaria havia, vez por outra, oscilações que teriam origem, talvez, no

\footnotetext{
${ }^{98} \mathrm{O}$ termo ações físicas, nesse contexto, é definido como os gestos e movimentos corporais que são subsidiados por sensações e pensamentos dos personagens.

${ }_{99}$ Do que Brecht escreveu, Millôr Fernandes transpôs para: “Quero ir-me embora daqui para sempre. Isto não me agrada. Vê, sofro um acidente no temor da noite, e assim mesmo faço tudo para chegar na hora e olha como me tratam. Ah, Frederico, isso me faz lembrar o filho pródigo: já imaginou o que seria da história se, quando ele voltasse, em vez de um vitelo gordo e fumegante, a família lhe tivesse dado uma esculhambação? Vou-me embora" (BRECHT, Bertolt. O senhor Puntila e seu criado Matti. Rio de Janeiro: Paz e Terra, 1993, p. 26).
} 
excessivo respeito à ordem das frases e ações da cena. A partir das apresentações em que passei a me ater mais às coisas e aos movimentos físicos dos contextos, os ganhos apareceram. Lembro que após pegar uma garrafa de dentro do baú, aguardava que Helena a viesse retirar de mim. Em uma mudança de atitude a respeito da importância dos objetos de cena, ative-me à alegria do meu personagem ao se agarrar à bebida. Sem pressa para levá-la aos lábios, ele antes conferia a marca da cachaça, sentindo seu cheiro e deixando-se salivar para em seguida abocanhar o líquido redentor. E me entretendo com as peculiaridades de ter em mãos o que seria uma preciosidade para Cornélio, afastava a expectativa de quando exatamente a minha colega viria me arrancar a garrafa, deixando que seu gesto me surpreendesse.

Na primeira parte da nossa adaptação, diferentemente do original de Brecht em que Puntila bebia em um bar de hotel, Cornélio se encontrava em um trapiche de um pesqueiro, na companhia de uma prostituta, quando era abordado por seu motorista que havia três dias o aguardava. Decupo algumas observações sobre como eu agia para estar mais concentrado no começo da peça, equacionando suas barreiras e soluções.

Um artifício (aliás, dos mais conhecidos) era a escrita nos camarins do que talvez acontecesse com o meu papel cinco minutos antes da sua primeira aparição, o que ampliei para dez minutos, quinze etc. Anotava em uma folha se me encontrava no quiosque do local, se pedia ao garçom para me servir à beira do lago, se tinha ido ao banheiro, se perturbava o responsável daquelas instalações ou se fiscalizava a qualidade das aguardentes que estavam me vendendo. Lastreava ainda mais o percurso do meu papel refazendo o itinerário que o conduziu para fora da cidade, reconstituindo por onde ele tinha passado, como no fórum do município, a fim de visitar o amigo Frederico, o juiz da comarca, a quem arrastava até as imediações da lagoa para lá beberem, com a desculpa de terem que conversar a respeito de uma minha empregada comunista que eu dispensara. Nessa ampliação do que constava no texto, a questão da demissão me desgastava consideravelmente, visto ser este um dos principais entraves que acompanhariam meu personagem por toda a obra. Por isso, eu me enxergava no automóvel tramando junto ao juiz a negociação de como evitaríamos qualquer processo contra a minha pessoa. Espero estar me fazendo entender que as observações acima eram imaginárias e retroativas à minha primeira aparição na peça.

Assim, tanto à espera do terceiro para o primeiro sinal quanto no caminho entre os camarins e o cenário, buscava eu me colocar no lugar de Cornélio e, seguindo esse recurso, ao subir no palete que se passava por trapiche, via-me rodeado de águas que de fato não existiam. Mesmo que estivéssemos em posição de atores, em que meus colegas narravam e 
cantavam a abertura da peça diretamente aos espectadores, eu me colocava como quem estava planejando a pescaria. Externamente, eu compunha o grupo que iria contar aquela história e, internamente, me transferia para o papel, sem no entanto destoar da postura coletiva dos meus pares.

Sobre a cena em si, havia uma triangulação entre o garçom (Álvaro Franco), o fazendeiro e o chofer que havia 72 horas me esperava. Quanto mais eu desprezava os menores detalhes em pedir outra bebida ao garçom ou ignorava no trapiche a biscate mais bêbada do que eu ou, ainda, aguardava como ator a entrada de Rogério Bandeira como Vítor, menos me envolvia com a cena. Inversamente, se eu via a garrafa e os detalhes do seu rótulo nas mãos do funcionário do quiosque, se me detinha sobre as curvas do corpo daquela mulher da várzea insinuando-se ao meu lado e permanecia mesmo em dúvida se iria levar a sério ou fazer troça da irritação do meu motorista que, por sinal, atrapalhava a minha pescaria, mais concentrado estaria nas imperfeições do meu bebum.

De modo que, progressivamente, fui-me imantando pelos acontecimentos ao meu redor: ao mandar o garçom buscar uma pinga mais forte - " [...] aquela com a serpente dentro" ${ }^{-100}$, conferia se ele me obedecia ou fazia cara feia; para reverter o pedido de demissão que cometeria meu motorista com seus consequente direitos trabalhistas, mirava em suas pupilas apelando para uma sincera amizade com ele. Os gestos diziam mais que as palavras do texto.

"VÍTOR: Sr. Cornélio.

CORNÉLIO: Quem é você?” (BRECHT, 1993, p. 14)

Este era o primeiro contato entre os papéis títulos do original de Brecht - O senhor. Puntila e seu criado Matti, transformados em Cornélio e Vítor em $O$ patrão cordial, na versão da Companhia do Latão. A fim de não somente esperar a chegada do meu colega ao palco, eu inventava o voo de um mosquito à beira do lago, se ventava, se havia e como seriam as nuvens no céu e assim por diante. Deleitava-me ouvindo a canção em que a prostituta enrolava a língua e com a qual me identificava alegremente: "Corujinha que vida a sua, bebendo cachaça caindo na rua. Isso é bom corujinha, isso é bom [...]"101. Conferia se o farelo para atrair peixes que tinha jogado na lagoa afundava ou boiava e assim por diante. No

\footnotetext{
${ }^{100}$ Inserção textual de Sérgio de Carvalho sobre os originais.

${ }^{101}$ Cancioneta de domínio popular, reelaborada por Martin Eikmeier.
} 
microcosmo do papel (meu pequeno círculo de atenção), atinha-me às minudências imaginadas, de modo a ter a minha paz interrompida por aquele sujeito (meu motorista) que me chamava pelo nome e então outro jogo se iniciava. Um senão nessa passagem era aoscilação entre concentração e tensão. Reparei que, quando estava prestando mais atenção ao funcionamento da cena (como quando, em uma apresentação lotada, com gente sentada no chão, fiquei em dúvida sobre como Rogério Bandeira chegaria à sua posição, já que o público tomara conta do espaço) e menos jogando com a ficção, a minha tensão física se elevava e eu, por exemplo, apertava demais a vara de pescar em minhas mãos. Naturalmente que o contrário também se dava: se estava atento aos acontecimentos do enredo, vivenciando-os como personagem, diminuíam as tensões musculares.

Para aquele começo de peça, cheguei a estabelecer que claro que o conhecia, mas fazia troça do chofer para me divertir, alegando não saber quem ele era, à guisa dos interioranos que brincam com os seus em típicas armadilhas. Também porque ele seria um novo passatempo depois de três dias em que eu testara a paciência do pessoal do quiosque. Essas divagações me serviam de subtextos até o momento em que Vítor decidia entregar as chaves do carro e reclamava suas contas da função de motorista, alegando que eu o desrespeitara ao deixá-lo três dias esperando. Se o assunto envolvia dinheiro, algo calava em meu proprietário instintivamente no bicho capitalista que ele era, mesmo que altamente alcoolizado. Para reter o meu dinheiro, oferecia um trago a ele a fim de selar a amizade, valor acima da relação entre patrão e empregado. Desconfiado, o chofer cedia ao apelo do seu chefe pulando para o trapiche e os dois brindavam o afeto entre eles.

Talvez valha citar que, pela utilização de alguns exercícios encontrados em The Stanislavski's Technique: Russia ${ }^{102}$, como um em que o elenco observava com toda a atenção as características físicas dos olhos do parceiro, com foco nas particularidades dos glóbulos, íris, pupila e luminescência, dei-me conta que pouco via os olhos dos meus colegas em cena e a partir de então passei a me fixar no olhar do meu motorista. Assim, na sedução para que ele esquecesse sua indignação contra mim, eu seria sentimental, afeito à humanidade da nossa relação a ponto de lhe pedir desculpas pela sua lúcida doença: "Eu sofro uns ataques de sobriedade" 103 .

\footnotetext{
${ }^{102}$ GORDON, Mel. The Stanislavski technique: Russia. New York: Aplause Theater Book Publishers, 1998.

${ }^{103}$ Na versão de Millôr Fernandes: "Eu tenho uns ataques sim! Acordo e percebo, de repente, que estou sóbrio! Fresco como um pé de alface. Que é que você acha, é grave?" (BRECHT, Bertolt. O Senhor Puntila e seu criado Matti. Rio de Janeiro: Paz e Terra, 1993, p. 17).
} 
Gostaria ainda de dizer que, a exemplo de Eugênio Kusnet em Os pequenos burgueses, redigi, ao longo das temporadas dessa nossa peça, todos os supostos acontecimentos entre as suas cenas e os subtextos de todas as minhas falas ${ }^{104}$. Não posso afirmar que tais exercícios influenciam na qualidade da atuação teatral, apenas que me senti próximo da obra, além de me divertir.

\section{Motilidade}

Resisti, por mais de uma vez, às mudanças propostas por Sérgio, relativas à dramaturgia, à encenação e à atução. Mesmo sendo uma característica do grupo, não me foi tranquila a assimilação de que nada seria fixo entre nós e que, mesmo pouco antes de uma estreia ou com um trabalho já em cartaz, poderíamos tudo mover, quer em suas formas ou em seus sentidos. Provoquei atritos, resmunguei pelos cantos, carreguei queixas, pedi desculpas, até perceber que a plasticidade melhoraria o nosso teatro e a mim como intérprete e pessoa. Contribuíram para isso os anos de psicanálise e uma tomada de consciência de que eu não me transformaria se não me dispusesse a ser flexível na arte e na vida. Em O patrão cordial, provoquei dissensos não aceitando uma ou outra modificação na peça, e dias depois eu as percebia como razoáveis. No entanto, foi também nessa obra que, logo após a sua primeira apresentação no Rio de Janeiro, disse ao meu diretor parceiro: você fez de mim um ator.

\footnotetext{
${ }^{104}$ Renato Borghi me contou, em um depoimento para o meu livro Eugênio Kusnet: do ator ao professor, que Kusnet tinha um caderno sobre o seu personagem Bessemnov, no qual anotava todos os subtextos do papel, escrevendo praticamente uma dramaturgia paralela à de Os pequenos burgueses, de Máximo Gorki.
} 


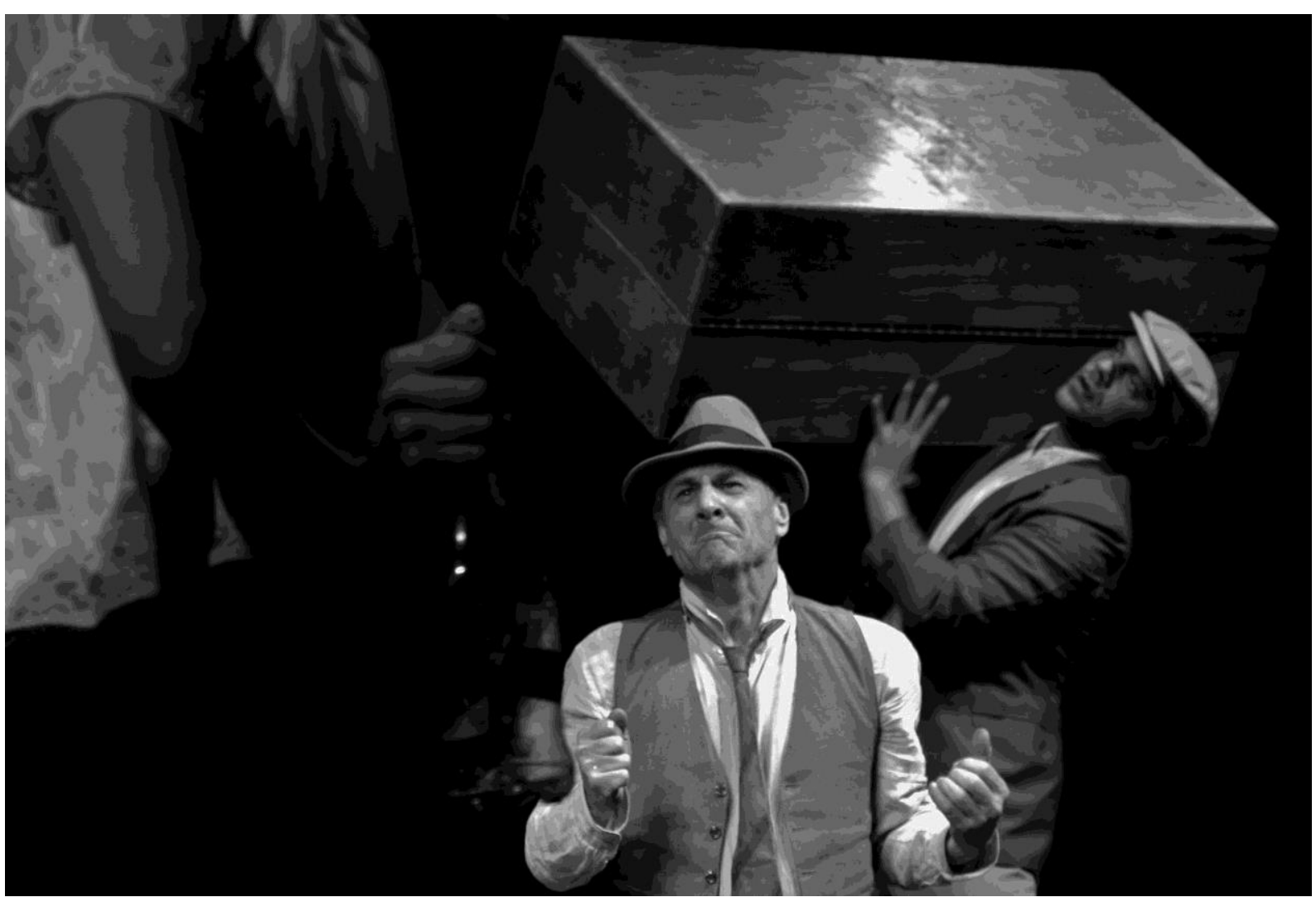

Helena Albergaria (Vidinha), Ney Piacentini (Cornélio) e Rogério Bandeira (Vítor). O patrão cordial, 2012. Foto: Sérgio de Carvalho.

\section{3 ÓPERA DOS VIVOS}

"As formas de mediação da acção são várias: o teatro, o cinema, o espetáculo musical e a telenovela. [...] Trata-se de um percurso da mercantilização da arte, do seu estado no passado e na actualdiade" (SANTOS, 2014).

O terceiro espetáculo que completou o Repertório 2104 da Companhia do Latão foi Ópera dos vivos ${ }^{105}$, que já tinha quatro anos de estrada. Foi paralela a esse intento do grupo a intensificação dos meus estudos sobre atuação para o mestrado, cujos reflexos se tornaram patentes nesta e nas obras posteriores. Lembro-me de quando, durante os preparativos do

${ }^{105} \mathrm{O}$ elenco de Ópera dos vivos estreou formado por: Adriana Mendonça, Ana Petta, Carlos Escher, Carlota Joaquina, Helena Albergaria, Ney Piacentini, Renan Rovida, Rodrigo Bolzan, Rogério Bandeira. Depois, também fizeram a peça: Fernanda Gonsales, Rony Koren, Álvaro Franco e Érika Rocha. Execução musical: Maurício Braz, Alessandro Ferreira, Cau Karan e Martin Eikmeier (também compositor). Direção de arte, cenografia e figurinos: Renato Bolelli e Vivianne Kiritani. Cenotécnica: Waldomiro Paes. Iluminação: Melissa Guimarães e Lígia Chaim. Coordenação técnica: Carlos Escher. Direção audiovisual e assistência dramatúrgica: Diogo Noventa e Luís Cruz. Assistência de pesquisa: Gabriela Itocazo, Gabriella Villen e Lia Urbini. 
projeto que se tornou o mais ambicioso do grupo, comecei a me perguntar se estava ou não transferindo para a prática diária as minhas pesquisas acadêmicas sobre interpretação. Permanece nítida em mim a tarde em que, nos cantos da sala, enquanto a equipe ensaiava e eu aguardava a minha vez, recuei para pensar no que teria acontecido com o meu personagemator Perene (do quarto ato de Ópera dos vivos) antes dele entrar em cena. O pessoal experimentava justamente uma cena sobre o atraso do meu papel a uma gravação de TV.

Imaginei que na noite anterior àquele momento ele havia dado uma olhada no roteiro das filmagens, o que não era comum para o meu veterano, e deparara-se com uma dúvida sobre o desfecho do seriado que vinha protagonizando. Inquieto, não dormira e quando acordou já estava atrasado para ir aos estúdios rodar o final da história entre um delegado e uma militante política da década de 1960. Especulei se teria ido de carro até a emissora de televisão ou de ônibus, mas escolhera um táxi pelo avançado da hora. Ele passara um tanto impaciente pela portaria da TV, caminhava até o estúdio, para finalmente entrar e dizer: “Estavam por mim?" (CARVALHO, 2104, p. 128).

Ao recuperar o que poderia ter se passado com Perene até que ele chegasse à filmagem, reconheci a distinção que isso fazia se comparado a apenas esperar o andamento dos ensaios para dar a minha frase. Como já reportei anteriormente, recorri a esse dispositivo em outros trabalhos, no entanto, eu não poderia esquecer esse episódio que vejo como uma reinauguração do meu interesse em criar o que acontece antes, durante e depois das cenas propriamente ditas, explorando a maior amplitude possível da vida dos personagens.

Ópera dos vivos foi a síntese da trajetória do Latão até 2010, pesquisada, improvisada e ensaiada por cerca de três anos. Foram diversas as referências que nos serviram para tratarmos da relação entre a produção cultural e o governo militar imposto a partir de 1964, com seus sucedâneos na atualidade. De uma ampla bibliografia sobre as causas da implantação da ditadura a entrevistas com artistas e críticos que viveram ou estudaram aquele período, passando por ver e discutir filmes e documentos, entremeados com inúmeros experimentos teatrais, videográficos e musicais, fomos estabelecendo os eixos sobre os quais viríamos a compor a obra.

Eram quatro módulos, com autonomia, se vistos separadamente, e interdependentes quando exibidos em conjunto. O primeiro ato, Sociedade Mortuária, abordava a gênese das Ligas Camponesas surgidas na década de 1950 no Nordeste brasileiro, pelo ângulo de um coletivo de teatro nos moldes do Centro de Cultura Popular da União Nacional dos Estudantes (CPC/UNE), com as inquietações do que sugeríamos ser a própria Companhia do Latão se confrontando com o motivo de se retomar teorias e formas de mais de meio século atrás. 
Tempo morto, o segundo ato, situava-se na iminência do golpe de 1964 e era um filme inspirado em Terra em transe, de Glauber Rocha.

Não mostrávamos os dilemas do jornalista-poeta protagonista da obra glauberiana, mas sim um banqueiro flertando com a cultura de esquerda, sem abandonar a sua classe que conspiraria para derrubar o presidente João Goulart. A terceira parte estava mais para um show musical do que para o teatro de prosa. Passado nos anos em que o regime de exceção se firmava, adeptos das canções de protesto tinham como polo os tropicalistas, que se antepuseram ao nacionalismo vigente na música popular brasileira de então. Como nos festivais televisivos de canções de grande repercussão à época, Privilégio dos mortos quase chegava à agressão física entre as duas linhas artísticas de musicar o Brasil pouco antes do fechamento político do país com o Ato Institucional $\mathrm{N}^{0}$. O quarto ato, Morrer de pé, acontecia na atualidade, revelando uma diluída apropriação televisiva da luta entre a direita e a esquerda política durante a ditadura. Não fosse a recusa de um velho ator, remanescente do teatro engajado daqueles duros tempos, em gravar suas falas, as marcas deixadas pelas violências ditatoriais seriam transformadas em um melodrama. Nesse ambiente, depois de ser conduzido ao vestiário, concomitante à cena que mostrava a preparação do principal plano do seriado, perguntava-me, na pele do velho ator, se iria ou não enfrentar o diretor a respeito de uma discordância em relação ao desfecho do seu personagem policial. Três camadas, portanto: eu como ator, Perene como ator-personagem e o delegado (personagem de Perene). Conturbava-me fora de cena pensando que seria melhor simplesmente filmar o previsto. Ao colocar a blusa de gola rolê, o paletó, um revólver enfiado nas calças pelas costas e uma peruca que me deixaria mais jovem, sentia (como Perene) que não valeria a pena me expor discordando do meu papel - um torturador que se arrependeria por amor. Silenciosamente refletia: "Deixa pra lá, homem. Faz a tua parte e volta para casa. De que adianta questionar o roteiro?”. Não obstante, ele abalaria a engrenagem daquela linha de produção.

Chegado o momento de Perene atuar, ao entrar no cenário, eu cuidava para não somente ir à marca no centro do piso, por saber que lá havia um sinal no chão determinando a posição do foco de um refletor. O personagem teria que ser posicionado pela assistente (Fernanda Gonsales), sem se antecipar, e eu, como intérprete, percorreria suas indefinições. A peruca em minha cabeça (além de provocar risos na plateia), seria penteada pela cabeleireira no set, com o veterano incomodado e contendo sua irritação com a falta de tato da maquiadora (Adriana Mendonça). Mas o que eu mais alimentava internamente era a dúvida em falar ou não com o diretor (Rogério Bandeira) a respeito do plano que seria rodado, por discordar que um delegado a serviço da repressão viesse a se arrepender de ter torturado a irmã de sua 
namorada e, por isso, se mataria. Para piorar, Perene não tinha como escapar das descabidas instruções do diretor sobre como representar o suicídio. Ao concordar discordando, eu ia para trás do set esperar o grito de “Ação!”. Embotado, nos fundos do estúdio, antes de começar a gravar, cumprimentava a figurante (Érika Rocha), procurando respeitar minha colega nas filmagens e fazendo de tudo para não interromper o fluxo da ficção, mesmo que ninguém estivesse nos vendo.

Ao entrar no cenário, a minha sobreposição como condutor de uma personagem-ator (Perene) que, por sua vez interpretava um delegado, fazia com que, em um primeiro momento, eu entrasse direto no policial, passando por cima do problema de que eu seria Perene pensando em como ele iria representar seu torturador (ver p. 100-102). Creio que na segunda ou terceira temporada passei a incorporar mais as dúvidas do veterano ator - se deveria ou não respeitar os exageros repassados a ele pelo diretor, como chegar transtornado ao apartamento da amante. Daí em diante eu entrava em uma zona insegura, tendo que adaptar à incorporação de Perene sua relutância em se matar como delegado diante de sua parceira, embora procurando seguir as indicações diretivas. Em uma atmosfera que transparecia um patético suspense, expondo ao público do teatro o aparato técnico das gravações, como, por exemplo, o operador do microfone que ora virava sua vara de som para mim, ora para minha partner, que também representava uma atriz (Dora Helena: uma viciada em calmantes, papel de Helena Albergaria); eu faria um Perene hesitante, com seus clichês de um ator ultrapassado andando lentamente em cena, indo para uma falsa janela cenográfica, pousando lentamente a mão em seu batente e virando-me bruscamente para dar a fala. Aqui, ao contrário da nossa estética contraditória, redundávamos em iluminação climática, assim como se ouvia uma sonoplastia misteriosa, corroborando com um padrão televisivo de que algo estranho estava para acontecer.

Difícil para mim era não recuar à consciência pessoal, embalando-me apenas como Perene nessa sequência. A tripla articulação requeria toda a atenção, para que houvesse coerência até nas incongruências. Contudo, havia um flanco aberto nessa geometria atoral, visto que Perene dizia-se um ator que não lia os roteiros e, assim sendo, perguntava-me como ele emitiria corretamente as frases do texto antes de decidir mudar radicalmente o desfecho de seu delegado? Para sanar essa dúvida, tinha mapeado comigo que, na noite anterior, ele havia dado uma olhadela no script, o que o deixou intrigado com a opção do roteirista em fazer dele um policial que sente remorsos por ter agredido a ativista irmã de sua amante e, talvez, por ter relido mais de uma vez a cena, a teria memorizado. 
No ápice do quarto ato da obra, o desacato do velho ator causaria espanto na equipe: no lugar de levar o revólver ao seu tímpano, Perene o apontava para Dora Helena, dizendo: “Eu preciso te matar. Eu vou até o fim” E a indignação do diretor, bradando: “Corta!"; “Desculpa, Perene, mas é só você puxar a arma e colocar na sua cabeça e atirar...”. Porém, o personagem replicava: "Ele não tem que morrer" e "Este homem é um delegado, um carniceiro. Acostumado com o sofrimento dos outros. Não sente remorsos, não se mataria" (CARVALHO, 2014, p. 136); rebelando-se diante de todos, o que levaria à suspenção das tomadas.

Na sequência, nos bastidores (não fazendo parte da peça), eu me remoía com o que acabara de acontecer: "Por que fiz isso? Um surto na frente da equipe, que vergonha. Preciso me redimir, pedir desculpas...". Mais calmo, ao retornar ao estúdio, procurava explicar que conhecia aquela gente e que eles não se retratariam: "Não se humaniza um torturador". Tudo em vão. E, diante do contra-argumento da direção que igualaria delegados e guerrilheiros, por serem "duas pontas da mesma ferradura" (CARVALHO, 2014, p. 138), o sangue do veterano subiria novamente a ponto de ele improvisar de chofre, junto à assistente de direção, uma agressiva versão de como teria agido o agente da repressão naquela situação. Feroz e insinuando que havia torturado a militante sexualmente, provocava a assistente esfregando a arma em seu corpo, até que ela o interrompesse, dizendo: "Para! Por que você não morre de uma vez?!" (CARVALHO, 2014, p. 139), referindo-se ao ator que se recusava a se matar como personagem.

Menos do que contar como era a fábula, o que cabe aqui é discutir se Perene já tinha em mente uma alternativa ao roteiro ou se o improviso lhe veio na hora, como pura reação ao acinte do diretor que insistia em separar a luta política do caso amoroso. Enquanto fazia a peça, eu voltava a essa inquietação sem que ela tivesse sido por mim resolvida. A rigor, eu teria que ter claro se meu personagem reagiu repentinamente como delegado afrontando sua amante ou se havia articulado isso anteriormente. Hoje percebo que algum desleixo me impediu de, por exemplo, escrever sobre essa lacuna, pois era insuficiente só imaginar que Perene vertia seu defensor da direita brasileira em um violento doentio. Teria ele cogitado isso em casa, na noite anterior, em que perdeu o sono por não aceitar o final daquela história? Chegou a ensaiar sozinho como apontaria a arma para Dora Helena, fazendo de algum objeto doméstico o revólver do torturador? Enfim, deveria ter me indagado sobre os pontos relativos às ideias do meu duplo papel de um ator de 60 anos travestido de investigador de polícia. Sabemos que jamais daremos conta da vida integral dos personagens, embora o que me 
inquiete é por que não nos dedicamos acima da nossa própria média, seja ela superficial, a contento ou sistemática?

$\mathrm{Na}$ dramaturgia deste quarto ato de Ópera dos vivos, Anita, a assistente de direção, cobrava rispidamente de Perene que ele gravasse de uma vez a sua morte. Ela era uma pragmática defensora da padronização da televisão, que naquele momento estava emperrada pelo posicionamento político fora de hora do tarimbado ator. A discussão entre eles resultava na sua saída do estúdio, após dela ouvir: "O roteirista é pago para escrever as falas e os atores são pagos para dizê-las: divisão do trabalho!” (CARVALHO, 2014, p. 140). Em uma nova rodada de interrogações sem contracenar com ninguém, como preparação para a volta do personagem dali a alguns minutos, considerava que bater de frente com a intransigência da assistente não funcionara e vinha-me então uma opção que seria a de falar a Anita do quanto a mãe dela - Júlia, uma atriz politizada desaparecida - tinha sido um modelo de resistência. Traria um assunto pessoal, falando da solidariedade entre um conjunto de pessoas que fizeram parte de um mesmo projeto para a transformação do país e que ela, Anita, era um fruto desse tempo. Ao reentrar no estúdio e chamá-la, enquanto eu lembrava o talento de Júlia como artista e os riscos que ela havia corrido, Anita insistia que eu (Perene) filmasse, levando-me a um inconformismo emotivo. E não deixava de ser sincero o meu comprometimento afetivo com a desilusão de Perene, por atestar que muito pouco restara da utopia de sua juventude, o que não estava distante das desilusões da atualidade.

Adiante, desdobrava-se o impasse geral e Perene sentia que talvez já fosse a hora de ceder e gravar a cena de sua morte, pois percebera que sua revolta não tinha eco. $\mathrm{Na}$ contramão, pensava que deveria resistir e assim passava à cena seguinte, em que voltaria a se comunicar com Anita, agulhando-a. Ao lembrar que o produtor chefe (que aparecera no andar de cima do estúdio, dando a entender que aquele imbróglio deveria terminar e logo) fora também de teatro, perguntava a Anita se a mãe dela se orgulharia de nós, que estávamos trabalhando sem senso crítico para a máquina da televisão. Ao confrontá-la afirmando que ela ganhava a vida esquecendo de onde vinha, a assistente caía em um choro pela minha insistência em voltar ao assunto sobre a sua mãe. O caos se instaurava novamente no ambiente, acrescido de um discurso de uma Dora Helena alcoolizada e drogada em pílulas, mas com suas razões acerca da vida do futuro que lhe aguardava quando envelhecesse. Porém, ao ouvi-la, eu flutuava entre aceitar ou rejeitar sua lúcida loucura, por fim resignandome a filmar o plano do suicídio e acabar de vez com tudo aquilo. Tomada a decisão, o que me ocorria internamente, ao presenciar os preparativos para as filmagens, era que voltaria ao meu 
isolamento e solidão, não apenas de um sexagenário ator, mas de uma pessoa que já não tinha tantos motivos para viver.

Próximo do término da peça, se fosse me abster do personagem, relaxaria dizendo-me que, para mim, o espetáculo já havia acabado, pois não teria mais falas. Mas continuava simulando o papel procurando pensar o que estaria se passando pela cabeça de Perene. "Muito bem, que patetice essa sua revolta de araque. Se antes quase já ninguém te convidava pra trabalhar, daqui para a frente é que você vai mofar de vez naquele apartamento de paredes descascadas." Era quando Dora Helena e Perene se mediam em olhares perdidos. Nesse sentido, houve involuntariamente laivos de memória emotiva ${ }^{106}$, comigo lembrando das ocasiões em que fiquei apartado do teatro.

No desfecho da obra, com meu personagem derrotado e sem perspectivas, vinham-me projeções da minha própria inutilidade como ator e ser humano e chegava a entristecer em cena, confundindo-me com meu papel, o que não é recomendável, porém, às vezes, torna-se inevitável.

\section{Privilégio dos mortos}

No terceiro ato da peça, eu fazia um Perene jovem, com breves aparições da plateia, enquanto no palco acontecia a transmissão pela TV de um show em homenagem a Miranda (Adriana Mendonça), uma cantora que regressara de um coma de três anos e que era comprometida com as causas sociais que vigeram durante o acirramento do regime militar. Como ele já era ator por volta de 1968 e em 2010 tinha mais de 60 anos, Perene àquela altura teria entre 20 e 25 anos de idade. Sem determinar exatamente em quais espetáculos ele poderia ter trabalhado, eu tinha uma noção do ambiente teatral daquele período por estar pesquisando, paralelamente às temporadas que fizemos no Rio de Janeiro e em São Paulo, a biografia de Eugênio Kusnet ${ }^{107}$, que havia atuado no Teatro de Arena e no Teatro Oficina, e também por conhecer um tanto da história do teatro brasileiro. O certo é que Perene formava uma dupla de espectadores daquele musical com uma amiga (Fernanda Gonsales) que estava escondida para não ser presa. Na plateia daquele show, intervínhamos, como fazia o público dos festivais de canções daqueles tempos, aplaudindo ou vaiando entusiasticamente.

\footnotetext{
106 Termo criado por Stanislavski que diz respeito ao empréstimo das emoções da vida do ator aos seus personagens.

${ }^{107}$ Os estudos sobre o mestre Kusnet modificaram minha visão a respeito da arte de atuar. Maria Thais Lima Santos, minha orientadora no mestrado, me disse: "Há vinte anos que vejo você atuando e algo está mudando". Sérgio de Carvalho, por sua vez, comentou: "Depois que voltou a estudar, você adquiriu mais consciência do ofício".
} 
Miranda interromperia seu show com dizeres anticapitalistas e seria arrastada para fora do palco pelo seu produtor e marido. Assim, os músicos que sobravam no palco mostrariam suas criações de cunho tropicalista, deflagrando um conflito que beirava a luta corporal entre nós, os espectadores engajados, e eles, os "desbundados". E foi disto que consolidamos um aprendizado que vínhamos circundando em outros dos nossos processos. Das vaias e bolas de papel que jogávamos da plateia naquela banda, o bate-boca se acirrava com eles nos retrucando. Como intérpretes, por sabermos de antemão que seríamos impedidos por Renan Rovida (ator condutor do cantor Belelo), mal principiava o combate e nos afastávamos involuntariamente.

Sérgio de Carvalho percebeu esse rasgo detectando que eu, quando recuava pelas pernas, lograva pela metade a ação do confronto, recaindo em um vesgo atoral de mais cuidar que um colega não se machucasse do que o irracionalismo dos personagens sem freios naquela confusão. Não afirmo com isso que devemos nos ferir em cenas de lutas, porém, sem abrir mão do domínio técnico, não podemos recuar de risco em tais momentos. Creio que este foi um dos mais claros exemplos entre os atores da Companhia do Latão de que, sem que o notássemos, seguíamos uma convenção entre parceiros desservindo o enfrentamento muscular requerido pelo evento.

\section{Tempo morto}

O segundo ato do espetáculo era um filme em preto e branco. Como uma parte fixa do espetáculo, depois de gravada e editada, ela não mais se modificou. Com a ressalva de que o estilo interpretativo desse média-metragem não seguia os padrões cinematográficos, por sua filiação a Glauber Rocha, cuja mobilidade de câmeras e intensidade nas interpretações são características. Nessa película, eu representei um banqueiro que iniciava o sobrinho (Rodrigo Bolzan) no mundo das finanças.

Por estar mais concentrado do que a média naquelas gravações e por conhecer a figura real em que estávamos nos baseando (Magalhães Pinto, proprietário do Banco Nacional), que agiu em favor do golpe militar no Brasil em 1964, o resultado na tela não foi dos piores. Registro isso porque, três meses após o fim do repertório do grupo de 2014, em um encontro que tive com Sérgio de Carvalho, ele comentou que estava editando o vídeo das outras três partes de Ópera dos vivos e havia constatado que eu ou fazia os personagens pensando na câmera ou me interiorizava em excesso, limitando a comunicabilidade fílmica.

Não saberia dizer ao certo de onde vem esse desequilíbrio e especulo que as exterioridades advenham dos anos em que filmava muitos comerciais para a televisão, o que 
me rendia uns trocados, mas que pode ter me prejudicado pela objetividade exagerada que me era solicitada naquele formato de trinta segundos. Por outro lado, entre meus 28 e 30 anos de idade, os cerca de trinta meses em que fiz ao vivo um programa educativo infantojuvenil na TV Cultura de São Paulo (o Revistinha) podem ter contribuído para a minha baixa introspecção atoral, automatismos que os meus então dezessete anos de trabalho junto ao Latão não conseguiram eliminar.

O contrário, um ensimesmamento, a ponto de impedir a transmissão do que foi captado em imagens, deve-se, possivelmente, à suposição de que uma diminuição de tônus atoral viesse a proporcionar a interiorização requisitada pelo audiovisual. Penso que uma melhoria nesse sentido seria possível através das mesmas insistências que fizemos teatralmente, as quais nada mais foram do que tentar e errar, reestudar e tentar novamente, indagando-nos acerca do que estaria nas raízes desses problemas e, sobremaneira, com disposição para admitir equívocos na direção de suas correções.

\section{Sociedade mortuária}

O primeiro ato da peça expunha a gênese de um histórico movimento agrário em que eu representava um dono de terras e também um camponês O Capitão Quirino era um latifundiário nordestino que, a princípio, apenas desconfiava das reuniões dos campesinos, embora passasse a reprimi-los violentamente quando se sentiu afrontado pela organização dos trabalhadores rurais. Já meu segundo papel, Abdias, tomava parte na incipiente associação dos agricultores, pela qual chegou a discursar.

A minha primeira intervenção na pele do Capitão dava-se na presença dos filhos do recém-falecido marceneiro do engenho. Perto do fim de mais de cem apresentações, foi porventura que me apropriei um pouco mais daquela cena inicial. As palavras estavam comigo em todo o encontro entre mim e os descendentes do mestre José, exceto quando era desafiado por um deles em um duelo de ditados populares. Por mais que me preparasse, ao me dirigir à dupla de filhos do marceneiro morto, costumava acelerar minhas falas, com domínio parcial dos porquês do personagem. Vou antes destacar o recuo ao encontro de Quirino com os jovens Aristeu e Marivaldo (Álvaro Franco e Renan Rovida) para, em seguida, discorrer sobre os obstáculos de cena em si.

Eu mesmo, na abertura da peça, fazia o falecido marceneiro, estilizando o morto em pé diante do público. A operação que vale resgatar, ocorrida no decorrer das temporadas de Ópera dos vivos, é a de que passei não só a acompanhar, de olhos fechados por estar sendo velado, o que a família e os presentes discutiam sobre o destino do corpo de José, como, 
simultaneamente, imaginar-me como Capitão que dali a pouco iria ao encontro dos filhos do artesão.

Ocupava-me em saber o que se passava ao meu redor e, ao mesmo tempo, em pensamentos, uma vez que estava parado sem nada enxergar, via-me na capital (Recife), divertindo-me em um prostíbulo, depois no saguão do hotel no dia seguinte e voltando ao interior, em minha caminhonete. Cheguei a visualizar como eram os objetos das décadas de 1950 e 1960, desenhando mentalmente cinzeiros de metal, a caneta com que o atendente do hotel dava baixa na minha saída, o marfim do volante do carro com o qual retornava e o câmbio de mão para a troca de marchas, como os de alguns veículos daquela época. Isso tudo era uma espécie de inventário das coisas que rodeavam o mundo daquele homem.

Na transição entre a casa da família do mestre José e a marcenaria da fazenda, em que uma música sustentava o revezamento do elenco, no percurso para me desfazer do morto e me aparatar como Capitão, presumia, ainda com a roupa de José morto, que aquele era o caminho que fazia já como Quirino, pisando nos degraus da escada da varanda que me levariam até a sala da minha residência no engenho. Ou seja, fazia dos passos que dava na diagonal inferior da frente do palco até a sua lateral - na qual deixaria o paletó e os sapatos pretos do defunto e vestiria as roupas do Capitão - o traçado do novo personagem que logo estaria diante dos filhos de seu ex-empregado. Sendo que, ao colocar um chapéu e outro paletó creme, era como se, fora de cena, eu já vivenciasse o personagem se arrumando para ir ao barracão e ter com Aristeu e Marivaldo.

Nesse átimo, a poucos minutos de entrar em cena, incorporando meu dono de engenho, silente repassava imaginariamente um diálogo com minha esposa (inexistente na peça) e que eu já havia improvisado sozinho antes de algumas apresentações, com o seguinte teor:

MULHER: Quirino, você vai aparecer de garrafa na mão diante dos filhos do morto?

QUIRINO: Qual o problema?

MULHER: É falta de respeito.

QUIRINO: Esse lugar é meu e eu faço o que eu quiser.

MULHER: Você já não foi ao velório e ainda vai falar com eles bebendo?

QUIRINO: Eu vou oferecer um trago aos dois em homenagem ao mestre José.

MULHER: Tudo é desculpa para você beber, Quirino.

QUIRINO: Deixe-me, mulher. 
Apesar dos esforços para aterrar o meu personagem, em diversas ocasiões, consciente ou não, despejava meus textos, sem verificar se o que Quirino dizia estava ou não chegando aos seus empregados. Um ganho aconteceu quando passei a prestar mais atenção neles e menos em minha própria voz. Enquanto oferecia aguardente aos dois, lamentando minha ausência no enterro do marceneiro, interessaria-me a reação deles. O limiar entre um ator que se censura ou que se aprova e um personagem que age para os outros, auscultando-os, era o fiel da balança nessa minha participação em Ópera dos vivos.

Sendo assim, quanto maior fosse meu foco em como cada um deles aceitava os copinhos de cachaça que eu oferecia para homenagear o falecido - o que a bebida causava em seus olhos, qual dos dois me era mais afeito ao se aproximar um pouco de mim -, mais aumentaria a confiança na relação entre os papéis o que, por sua vez, diminuiria as minhas preocupações do ator que vigia se a cena está indo bem ou não. Quero dizer: aqueles detalhes com os quais a vida mesma nos diz, indiretamente, se estamos ou não conquistando quem nos ouve é que fariam crescer a confiança na relação entre os personagens, reduzindo as minhas preocupações do ator que vigia se a cena está indo bem ou não.

Foi ainda nesse módulo que comecei a cultivar a continuidade dos pensamentos dos personagens saindo de cena. Se criar o que antecede uma situação que é mostrada ao espectador é comum para um ator, talvez não o seja não desistir do personagem quando ele vai para as coxias (conforme discutido no subcapítulo 2.2, sobre $O$ patrão cordial). Desse modo, o meu Capitão, depois de perder para Marivaldo num duelo de ditados, saindo de cena, reclamaria consigo que havia feito uma gentileza aos filhos do finado e ainda tinha que ouvir desaforos. "Deixa estar, uma hora eu dou o troco pra este engraçadinho...", comentava da boca para dentro, enquanto eu mudava de roupa para logo vir a ser Abdias no episódio seguinte.

Se a minha apreensão pessoal encolhia a austeridade do meu latifundiário, Helena Albergaria representava uma professora de adultos serena, sem pressa e de acordo com o tempo da situação. No segundo movimento da obra, encenávamos um grupo de camponeses que acompanhava as explicações da educadora que adotara o método de Paulo Freire de alfabetização.

Como um dos moradores da vila rural, aproximava-me com vagar do núcleo em volta da professora e ventilava-me de que aquilo não era uma aula por estarem eles conversando e não diante de um quadro-negro com giz. Na medida em que me aproximava, ouvia que o assunto da professora aludia ao nosso trabalho na cana-de-açúcar e na lida com as cerâmicas de barro, de maneira que ia me interessando. Assim, baixava minha desconfiança e me 
introduzia no meio dos companheiros. Em cena, quando deixava de pensar como Abdias, ninguém notaria a diferença, uma vez que eu estava na sua periferia. Mas, para mim, era significativo estar envolto no universo desse meu outro personagem, atuando sem falar e formulando opiniões internas que ficariam só comigo.

Em seguida, nós, camponeses, articulávamos uma assembleia, na qual eu discursaria e o meu teor seria a comparação dos donos de engenhos com os animais da região. Para justificar como eu me posicionaria na reunião, inventei que Abdias havia presenciado um encontro político em que um líder popular nordestino, como, por exemplo, Francisco Julião $^{108}$, discursara usando a mesma comparação de gente com bichos. Então eu adaptaria a fala dele, o que daria a impressão de que aquelas associações eram minhas. Então projetava (como estava no texto da peça) que os mandantes da região seriam: Dona Ester, uma leoa; Coronel Aquino, uma águia; e o Capitão Quirino, um morcego, sendo este o primeiro alvo do nosso movimento. Não obstante, nem sempre fluíam aquelas palavras, por eu carregar uma dúvida, provavelmente oriunda de uma elaboração insuficiente junto ao meu papel de Abdias, quanto à sua capacidade em construir uma adivinha do gênero: "Tem mama, mas não é uma leoa. Tem asas, mas não é uma águia... É o morcego! O Capitão Quirino!” (CARVALHO, 2014, p. 32).

Ao encerrar essa intervenção, eu dizia que o Engenho Bom Jardim, porque "[...] não produz mais nada, vive de sugar o sangue do nosso pescoço" etc., seria onde deveríamos nos estabelecer. E concluía: "É ali que temos que fincar nossa enxada!" (CARVALHO, 2014, p. 32).

Como já discorri, a interrupção dos pensamentos do personagem era tanto menor quanto maior era o meu envolvimento ficcional com a visualização do que Abdias dizia: “O [Engenho] Extremoz? Tem o fogo ainda aceso, emprega muitos de nós no canavial e a proprietária, Dona Ester, é uma leoa" (CARVALHO, 2014, p. 32). Ao emitir essas palavras, transportava minha mente a um terreno elevado e, especificamente, ao falar "Extremoz", via a fumaça saindo de uma chaminé de tijolos de barro; ao dizer “[...] fogo ainda aceso", pensava nos companheiros peões arremetendo facões contra os pés de cana-de-açúcar, vinculando cada frase a uma imagem. Em seguida, escutaria os argumentos de Vitorino, temendo pelas escorregadas do bêbado Marcelino (Rogério Bandeira), que fazia questão de discursar. Como interioranos, estávamos começando com as reuniões associativas e eu (que pessoalmente já tinha a experiência das plenárias do setor cultural) haveria de me abstrair disso, voltando-me

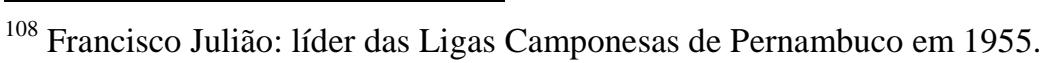


ao aspecto inaugural daqueles ajuntamentos. Assim, eu medrava sobre as propostas confrontantes de Vitorino e via que Marcelino, mesmo alcoolizado, estava lúcido em seus cálculos sobre as espertezas de Dona Ester em alterar a medida da vara que calculava o trabalho dos camponeses no corte da cana. Existe tanto ou mais trabalho ao nos interessarmos pelos outros do que quando falamos em cena. Reparem se, ao prestarmos toda a atenção nos personagens dos nossos colegas com suas incisões cênicas, não estaremos alimentando as nossas próprias incisões.

Em meu retorno a Quirino, eu iria receber a visita dos fazendeiros vizinhos acompanhados de uma estrangeira que fora encontrada pelo meu filho em minhas terras. A estupidez daqueles arcaicos latifundiários, que fazíamos em registro tipificado, requeria um contraponto realista e eu me voltava a essa vertente durante o interrogatório àquela missionária. Para dois dos coronéis presentes, se um fuzil encontrado na região era russo, a moça seria uma agente do comunismo soviético que vinha se infiltrando na formação das ligas camponesas ${ }^{109}$. Era preciso levar a sério aquelas hipóteses absurdas levantadas pelos meus compadres de que os olhos daquela mulher eram azuis por serem de vidro, uma vez que os socialistas do Leste Europeu tinham sido capazes até de enviar uma cadela em uma nave espacial.

Mas, principalmente pela pressão de que os camponeses vinham se organizando para tomar as nossas posses, eu teria que reagir. De sorte que arrancaria a arma das mãos de um dos coronéis e atiraria contra o céu a fim de atingir a cadela astronauta. Nesse aspecto, para que sublinhar o que já era esdrúxulo? Quando a dramaturgia fornece a comicidade, nós, atores, podemos levar a sério o material das cenas, posto que os personagens não se acham ridículos. Ao contrário, acreditam nas suas excentricidades.

Ecoando uma quietude que diz, em outra das transições na qual deslocávamos os poucos componentes da cenografia, carregávamos uma armação de cavaletes e tábuas usadas, que se desdobravam em diferentes formas a cada cena e, desta feita, indicavam um féretro (sem caixão ou corpo) de uma das tantas mortes pelas precárias condições de vida do povo nordestino daquele período. Não posso falar pelos meus amigos do elenco, no entanto, mesmo sendo este momento paralelo ao principal da cena, sentia-me abatido pela perda de mais um entre os que morriam pela falta de uma dignidade mínima. Exatamente, desconhecia a causa da morte e, ao estacionarmos a estrutura que levávamos, ao visualizar um buraco na terra e

\footnotetext{
${ }^{109}$ Na década de 1950 imperava no mundo a Guerra Fria entre os Estados Unidos e a União Soviética, contrapondo o capitalismo ao comunismo.
} 
me ajoelhar para nele jogar um punhado de terra, comovia-me sem me preocupar se alguém via ou não o que comigo se passava. Alguém diria que isso é inútil teatralmente, por não ser presenciado pelos espectadores. Um ou outro ator cingir-se ou não em um evento periférico, na verdade, não tem tanta importância, no entanto é de pensar na lassidão da obra como um todo se cada atuante se desligar quando não estiver no centro dos acontecimentos.

Retomando o Capitão, na cena seguinte, enquanto presenciava pela lateral do palco a professora, Marivaldo, sua mãe (Adriana Mendonça) e a negra Élia (Érika Rocha) à beira do açude, ia prevendo que dali a pouco voltaria ao espaço cênico e sairia da casa para tomar um ar e dessa vez com sossego, após ter mostrado a todos a minha força ao atirar em estrelas. $\mathrm{Na}$ preparação para o que viria a acontecer, acalmava-me internamente desfrutando da minha fazenda, isso porque, como ator, eu sabia que Quirino iria se descontrolar a seguir. Impedindo-me de me enervar desde o começo da sequência, iria apenas até o pátio para dar uma voltinha. Ao notar um desconhecido em companhia do meu filho com um equipamento que eu ignorava, intrigava-me com aquela conversa entre eles sobre a colocação de cercas na fazenda.

Ao saber que aquele estranho era da capital, apesar de não concordar com a demarcação dos meus limites, tinha que ouvir os argumentos do meu herdeiro aventando que os camponeses estavam aprendendo que havia "muita terra para pouco dono" (CARVALHO, 2014, p. 51). Ou seja, deveria acumular um a um, dos informes que recolhia, os motivos que me levariam à explosão. Do alerta filial, eu iria tirar satisfações junto a Aristeu, um dos filhos do falecido marceneiro. Como já estava desconfiado, entendia as simples respostas daquele empregado como ameaças ao direito à propriedade.

Minha cisma chegava ao ponto de, ao ouvir do jovem que ele estava aprendendo o beabá na escola da vila, eu passar a supôr que b + a iria compor a palavra "Cuba!"; e que a cor da cartilha seria vermelha, chegando a cantar um mambo ${ }^{110}$ e dançar nervosa e pateticamente na frente do inocente irmão de Marivaldo. Tomado, mal distinguia a voz do agrimensor que estava com o meu filho e, ao ser por ele desrespeitado, subia-me o sangue. A partir daí, partia para cima de todos bradando que eu ia comprovar quem mandava naquele lugar, possuído pela ideia de que todos estavam conspirando contra mim. Todavia, a ira do personagem não deveria contaminar o seu intérprete. Lembremos o que o crítico Décio de Almeida Prado observou sobre Eugênio Kusnet:

\footnotetext{
110 "Ta empezando lo velorio/ que le hacemo a Babalu/ Dame diez e sete vielas/ Ay pa ponerla en cruz./ Y dame un taco de tabaco mayenye/ Y un jarrito de aguardente,/ Dame un poco de dinero mayenye Pa' que me de la suerte/ (Coro.) Yo quiere pedi/ Que mi negra mi quiera/ Que tenga dinero/ Y que no se muera."
} 
Os nossos atores, quando querem dar a impressão de vigor, esbravejam, forçam a voz, destacam palavras, lançando-as ao público, forçando-o a aceitá-las. Kusnet, a exemplo de Ziembinski, vale-se de outros recursos, da variedade de timbres, percorrendo do falsete até a voz plena, numa modulação musical constante, persuadindo pela sutileza (PIACENTINI apud PRADO, 2014, p. 36).

Abdias ainda marcaria presença na reunião que ia determinar se a associação dos moradores confrontaria a destruição das casas comandada pelo Capitão. Sua conduta moderada, que defendia melhorias para a comunidade e não a luta contra a propriedade, resguardava uma impotência perante a coerção dos mandantes da região. Além do drama daqueles desvalidos sem meios para enfrentar a brutalidade dos latifundiários, eu me emocionava pela analogia do personagem comigo mesmo. Um sentimento governado pela impossibilidade de transformações substantivas que fossem capazes de renovar a vida das pessoas. Alto era o risco de uma revolta contra os grandes e o abatimento sentido pelo meu camponês por não haver como dar vazão à revolta calcava nele, e em mim, uma amarga resignação.

Ao cabo desse primeiro módulo de Ópera dos vivos, Quirino testemunharia os tiros que seu filho disparara contra Aristeu e Marivaldo. Enquanto o primeiro pretendia conversar com o Capitão sobre a situação, o segundo havia roubado a arma russa e, num rompante, apontava-a contra os donos do engenho. Na estilização da queda dos corpos dos dois que, sobre uma narrativa de Helena Albergaria, se posicionavam como atores no chão, eu, Rogério Bandeira (filho do Capitão) e Fernanda Gonsales (a americana) andávamos até perto dos corpos também como atores e, ao nos aproximarmos deles, entrávamos nos papéis.

Sérgio de Carvalho trabalhou conosco sobre essa passagem, apontando que eu me ajeitava para dar as falas e não me comprometia em realmente interromper com os braços e mãos os gritos da estrangeira. Anterior a qualquer frase, eu tinha a ação física de impedir que saíssem sons de sua boca. Em meio aos ajustes da direção, entendi que a prioridade era evitar que mais gente acordasse e visse os corpos, o que só aumentaria a perturbação. Ao final, o latifundiário se enrijeceria ao concluir que seus adversários caíram porque mereceram. Só e sem arrependimentos, bradava que mandara recado queimando a casa deles: "Quem nasce torto morre envergado", terminava o mandante. "Quem tem vida puxa por ela" (CARVALHO, 2014, p. 63) - responderia o empregado sem que o seu patrão ouvisse. Marivaldo tinha se fingido de morto para continuar vivendo. 


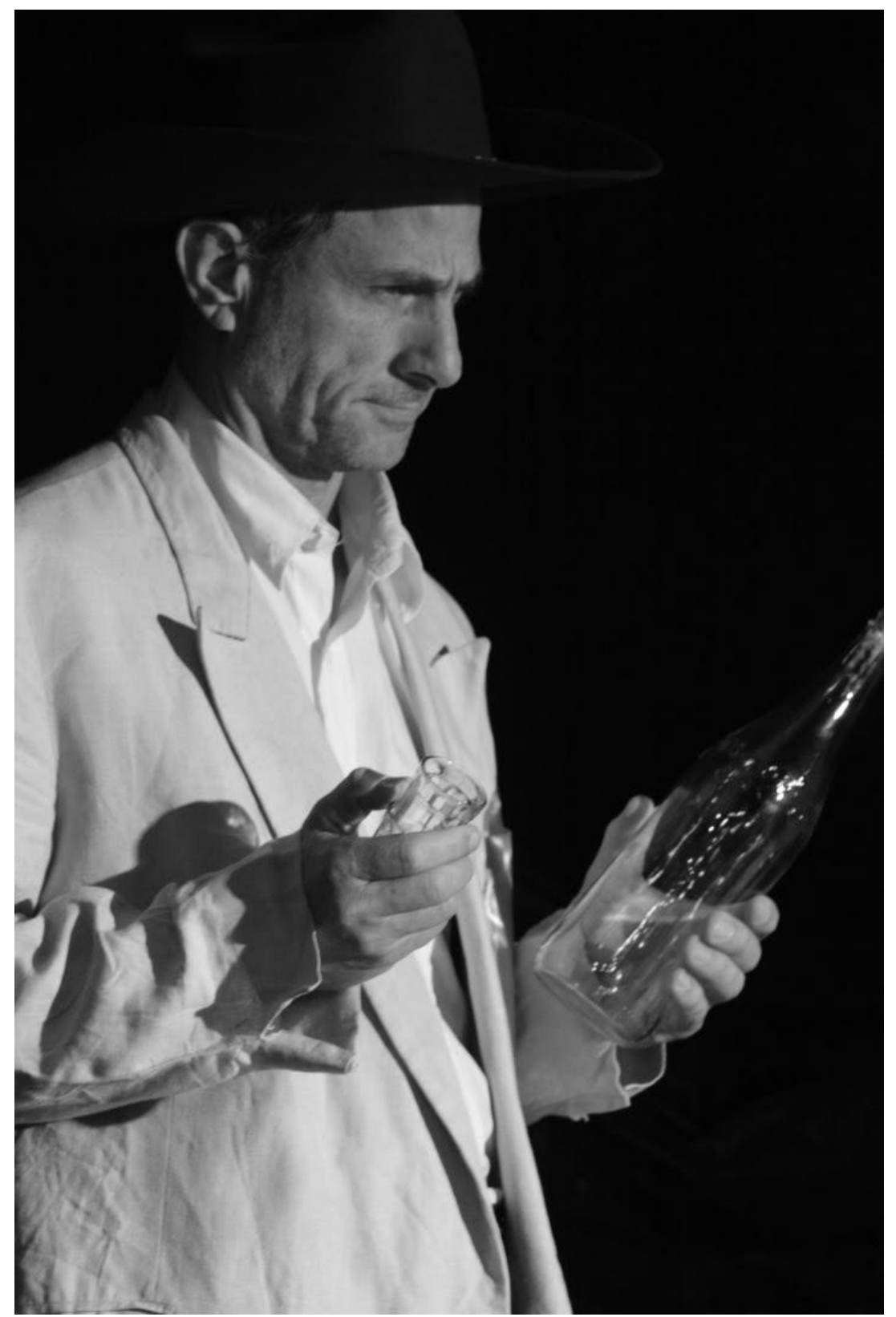

Ney Piacentini (Capitão Quirino). Sociedade mortuária - Ópera dos vivos, 2006. Foto: Sérgio de Carvalho. 


\section{CAPÍTULO 3-O PÃO E A PEDRA: UMA FÁBRICA COLETIVIZADA DE TEATRO (2016)}

Se no primeiro capítulo, a respeito das primeiras peças do grupo, o meu relato foi feito anos depois dos acontecimentos, o segundo, sobre o repertório 2014 da Companhia, foi produzido alguns meses após as apresentações das obras. Já este terceiro, que trata do espetáculo $O$ pão e a pedra, eu o anotei durante os seus ensaios e apresentações entre março e maio de 2016, com posterior revisão. Porém, antes mesmo dos encontros com todos do grupo se iniciarem, uma equipe de pesquisa levantou bibliografias e referências sobre o tema a ser enfrentado. De maneira que, quando iniciamos os procedimentos artísticos em torno dos problemas das greves de 1978, 1979 e 1980 nas cidades de Santo André, São Bernardo do Campo e São Caetano do Sul (ABC), tínhamos um amplo referencial a ser estudado. Do começo das práticas até a estreia foram intensas onze semanas de trabalho cênico e musical, prazo menor do que a média das nossas preparações. Como este acompanhamento foi feito em escritas diárias, irei abreviar as mais de uma centena de páginas em que registrei cerca de cem dias do processo, o que, naturalmente, excluirá parte das nossas investigações.

\subsection{OS PASSOS INICIAIS SOBRE O ENREDO E A COLABORAÇÃO DOS ATORES}

$1^{a}$ tarde de ensaios

No encontro inaugural, reuniu-se os companheiros e foram feitas as apresentações. No elenco, além dos parceiros anteriores, Beto Matos (que atuara conosco em Auto dos bons tratos e em $O$ mercado do gozo) voltava ao grupo e João Filho se integrou a nós, vindo do Núcleo de Estudos Anatol Rosenfeld ${ }^{111}$.

Com livros em suas mãos e nas do pessoal da pesquisa ${ }^{112}$, como $A$ vanguarda operária, de Celso Frederico, e Greve na fábrica, de Robert Linhart, Sérgio de Carvalho

\footnotetext{
111 O Núcleo de Estudos Anatol Rosenfeld é o espaço para as oficinas regulares da Companhia do Latão desde 2012 e, em 2016, foi coordenado pela atriz Helena Albergaria. João Filho participou do Núcleo de 2016 e também da leitura de Mutirão em Novo Sol (de Nelson Xavier), realizada em $1^{\circ}$ dez. 2015, na sede do grupo em São Paulo.

${ }^{112}$ A equipe de pesquisa temática foi composta por: Julian Boal, Marcelo Berg, Maria Lívia Góes Nobre, Natalia Belasalma, Olívia Tamie e Sérgio de Carvalho; no elenco: Beatriz Bittencourt (depois Debora Rebecchi), Beto Matos (depois Gabriel Stippe), Érika Rocha, Helena Albergaria, João Filho, Ney Piacentini, Rogério Bandeira, Sol Faganello e Thiago França; direção musical, composição: Lincoln Antonio; execução musical: Lincoln Antonio e Thiago França. Cenário e figurinos: Cassio Brasil; iluminação: Melissa Guimarães e Silviane Ticher;
} 
explanou que o nosso assunto seria o da relação entre religiosidade e política no Brasil nos fins dos anos de 1970. Debateríamos a histórica greve de 1979 na região do ABC em São Paulo, que se multiplicou por diversas partes do país e, do que entendi, iríamos ao encontro de uma real possibilidade de mudança que se deu naquele ciclo progressista em que a classe operária brasileira se organizou em um patamar que não mais voltou a acontecer no Brasil.

Contextualizações adentro, foram relatados episódios sobre as greves de 1978, 1979 e 1980. Estavam entre nossos objetos de análise as estratégias utilizadas pelos operários para que seus pleitos vingassem, a participação dos intelectuais, dos estudantes e da igreja católica politizada com as suas pastorais, assim como as reações dos empresários, do governo militar e da imprensa. Subjacente àquelas paralisações em massa, teríamos o tema da representação, como no caso da operação zelo, que consistia em quando os operários levavam à perfeição a fabricação das peças, o que fazia com que o todo da produção atrasasse. Era como se os trabalhadores cuidassem demasiadamente da confecção de um produto, não se limitando ao satisfatório, com um primor acima do normal, de modo que os fiscais não poderiam reclamar, uma vez que os operários estavam rigorosamente de acordo com os manuais da maquinaria. Ou seja, havia uma espécie de teatro dentro dos galpões com os trabalhadores sendo cuidadosos, mas engastando o mecanismo fabril.

Noutro flanco, não havia como desprezar a aproximação entre os católicos e as mobilizações. Vejamos uma fração de uma missa ao ar livre, proferida pelo bispo Cláudio Hummes, no dia primeiro de maio de 1979, que depois passou a fazer parte da peça:

BISPO - Cristo, os trabalhadores do ABC foram obrigados a fazer greve para procurar um pequeno aumento em seu salário, enquanto as grandes firmas multinacionais têm lucros enormes.

CORO - Cristo, ajude-nos a corrigir as injustiças. ( $A B C$ da greve. Direção e produção: Leon Hirszman. 1979/80. 16mm, 75min) ${ }^{113}$.

assistente de figurino: Patrícia Sayuri Sato; modelista: Alípio Gomes; costureira: Maria Alda Santos Gonçalves; motorista: Edivaldo Caetano da Silva; cenotécnico: Valdeniro Pais; ajudante de montagem: Fernando Batista da Cruz; dramaturgo assistente: Julian Boal; colaboração na dramaturgia: Helena Albergaria; registro videográfico: Natalia Belasalma; assistência de direção: Maria Lívia Góes Nobre; fotografias do cartaz: Cristiano Mascaro; arte do programa e cartaz: Marcelo Berg; assistência de produção: Olívia Tamie; produção: João Pissarra; dramaturgia e direção: Sérgio de Carvalho.

${ }^{113}$ Como a Bíblia foi outra forte referência para os nossos estudos, destaco o trecho que segue, retirado de Tiago 5: "Deus condena as riquezas mal adquiridas e mal-empregadas. Atendei, agora ricos, chorai lamentando, por causa de vossas desventuras, que vos sobrevirão. As vossas riquezas estão corruptas, e as vossas roupagens comidas de traça; o vosso ouro e a vossa prata foram gastos de ferrugem, e a sua ferrugem há de ser por testemunho contra vós mesmos e há de devorar, como fogo, as vossas carnes. Tesouros acumulastes nos últimos dias. Eis que o salário dos trabalhadores que ceifaram os vossos campos e que por vós retido por fraude está chamando; e os clamores dos ceifeiros penetraram até aos ouvidos dos Senhor dos Exércitos. Tendes vivido 
Por sua vez, formalmente nos guiaríamos tanto pelo aspecto documental, quanto pelo ficcional e ainda pelo fantasioso e onírico. Porém, todas essas sugestões desaguariam em improvisações e a feitura de recortes cênicos sobre os materiais. Em nossa dinâmica, cada atriz ou ator pensaria em cenas que seriam ensaiadas com os colegas para serem mostradas à equipe. Cenas gestuais, pediu-nos Sérgio, que deu como exemplo uma passagem do documentário $A B C$ da greve, na qual um camarada, antes de uma assembleia começar, acende seu cigarro em um outro que estava nas mãos do então líder sindical Luiz Inácio da Silva (Lula). O que o dramaturgo e diretor nos pedia eram teatralizados atitudes corporais. Essa linha de atuação, pelas ações físicas, ganhara contornos mais nítidos desde $O$ patrão cordial, peça da Companhia que estreara em 2012, como vimos no Capítulo 2.

Após um breve intervalo naquela primeira tarde de ensaios, começamos os trabalhos. Como o elenco iria se revezar na condução dos aquecimentos, fiz uma rápida mobilização física com todos e entramos em um exercício: andávamos pela sala até que alguém começasse a fazer um personagem, dando-lhe gesto e voz. Os outros atores poderiam improvisar junto a quem iniciou o jogo. Quando o maestro Martin Eikmeier passava a teclar no piano alguma música, a atriz ou ator que havia proposto a situação teria que interromper a cena e narrar sobre ela. Em uma rodada, surgiram um acidentado que falseava sua dor como forma de frear a produção de sua máquina, um médico que gostava das greves, pois assim ele folgava, uma trabalhadora que era abordada por um colega que a tratava como uma desquitada ${ }^{114}$, de maneira que ele se sentia no direito de se insinuar a ela etc. A quebra do vivenciado para o narrado tinha a função de ampliar os fatos e de provocar também mudanças de estilos, como já discutimos anteriormente.

A segunda ideia de jogo do dia veio de fotografias do livro Luzes da cidade ${ }^{115}$. Sozinhos ou em duplas, os intérpretes imitavam as posturas das imagens e uma parceira ou parceiro contracenava com uma ação ao lado de quem estivesse fazendo a pose da fotografia. Exemplificando, a partir uma imagem retorcida de Beto Matos, Érika Rocha entrou no jogo lembrando a ele que tivesse carinho com o parafuso, amor e cuidado, que aquilo não era só um metal retrabalhado, e a resposta de Beto como operário foi condizente. Helena Albergaria foi até o piano e pediu uma música e, quando Martin Eikmeier começou a improvisar, ela disse: "A canção do parafuso" e se pôs a vocalizar uma letra no momento.

regaladamente sobre a terra; tendes vivido nos prazeres, tendes engordado o vosso coração, em dia de matança; tendes condenado e matado o justo, sem que ele vos faça resistência” (Bíblia. Paulus: São Paulo, 1990, p. 1493).

${ }^{114}$ A futura personagem de Helena Albergaria (Joana Paixão) ganharia a pecha de desquitada em uma das cenas da peça, como reverberação dessa primeira improvisação.

${ }^{115}$ MASCARO, Cristiano. Luzes da cidade. São Paulo: Dórea Books and Art, 1996. 
Como se pode perceber, estávamos livres no começo daquela jornada, no entanto, os préstimos já se faziam presentes. Ou seja, poderíamos inventar, mas partindo do enfoque proposto. E para nos estimular ainda mais, recomendaram-nos uma série de filmes, como o já citado ABC da greve, Linha de montagem (de Renato Tapajós, 1981, 35mm), Peões (de Eduardo Coutinho, 2004, 35mm) e ainda reportagens de jornais e revistas da época. Acredito que esse projeto, de início, estava mais circunscrito do que Ópera dos vivos (2011 - nossa última produção dramatúrgica por inteira até então), pois, quando ele foi planejado, encontrávamo-nos longe do que viria a ser sua forma final. Mas não tão objetivo como quando usamos um texto já determinado nos moldes de $O$ círculo de giz caucasiano. Em $O$ pão e a pedra, me parecia haver uma pré-dramaturgia, que estava entre um e outro dos processos anteriores. E se fôssemos procurar por similaridades, em parte é possível que aqueles momentos transformadores e esperançosos contidos em Os dias da Comuna e A mãe - peças de Bertolt Brecht, e até mesmo os momentos primordiais da Revolução dos Cravos em Portugal, estivessem influenciando os primeiros passos dessa nossa nova frente.

$2^{a}$ tarde de ensaios

Sem relatar o aquecimento e as músicas, vamos às cenas que tínhamos preparado para aquele dia. A fonte era a exposição feita por Sérgio de Carvalho na tarde anterior, resultado das buscas realizadas pelo núcleo de pesquisa, porém não apenas isso. Rogério Bandeira, inspirado no livro Hamlet e o filho do padeiro, de Augusto Boal, mostrou-nos um padre comunista que, em suas pregações no interior da Bahia, perguntava-se quem iria mudar o Brasil e dizia que cortaria ele a cabeça de Herodes e Salomé, evitando a morte de São João Batista. Uma mulher (Helena Albergaria), com uma criança nos braços, narrava à parte, no começo e no final do discurso do padre aos seus fiéis, que seu marido tinha desaparecido e que ela iria para São Paulo. Bandeira, a certa altura, fazia apenas os gestos e a mulher dava seu depoimento sobre os movimentos mudos do padre. Um esboço que serviu para embasar, por exemplo, a futura figura do padre, mesmo que essa amostragem não ganhasse mais espaço no desenvolvimento da trama.

$\mathrm{Eu}$ apresentei uma cena em que, enquanto cinco de nós trabalhávamos em uma indústria, com as máquinas simuladas por duas cadeiras empilhadas, Beatriz Bittencourt chegava ao ambiente e colava na parede ao fundo os dizeres: "NÃO TRABALHE DE MÁ VONTADE, NÃO DISCUTA NO AMBIENTE DE TRABALHO" e "SORRIA SEMPRE". Com riso estranho, eu partia para cima dos meus parceiros e lhes dirigia frases bíblicas: "Eu vi descer do céu um anjo. Tinha na mão a chave do abismo e uma grande corrente. Ele 
segurou o dragão, a antiga serpente, que era o diabo, satanás, e o prendeu por mil anos"116. Ao me aproximar de Rogério Bandeira, forçava para que ele me furasse com uma chave de fenda, e, quando os demais me seguravam, eu dizia: "Você não é meu companheiro? Por que não foi solidário comigo?”. E o trabalho na seção voltava ao normal.

Sérgio pensou que, ao final dessa amostragem, eu poderia narrar o surto do operário como se eu fosse, além do surtado, também um trabalhador mais velho que tivesse visto aquele episódio, sendo meu narrador um obcecado pela razão e que, por isso, não enlouquecera como seu ex-colega mais novo. Um sendo o duplo do outro: o louco e o extremamente racional que, ao falar da loucura do primeiro, transbordaria seu descontrole contido. Relembro que fiz o exercício em função da direção ter levantado a hipótese de um personagem violento, sendo que mais tarde Sérgio propôs a Bandeira e a mim uma figura com passado de agressividades e um experiente operário, respectivamente.

Por entre as questões políticas e sociais, procurávamos pelas particularidades das vidas privadas dos embrionários papéis. Os problemas maiores, como a proximidade da greve, a ditadura militar ou os salários dos trabalhadores, teriam que refletir dentro das casas das pessoas que estávamos delineando. Por outro lado, enquanto o elenco preparava as pequenas cenas, víamos a equipe ligada à dramaturgia e à direção planificando o roteiro. Carvalho, entre outros pontos, dizia que um cronograma com o que havia acontecido durante a paralisação de 1979 no ABC deixaria tudo mais claro. Nessa conformidade, o processo avançava em duas frentes: os atores articulando e encenando ideias dramatúrgicas e o núcleo de pesquisa operando uma pré-estrutura da obra.

Em um segundo turno dos ensaios daquela tarde, o dramaturgo e diretor distribuiu ao elenco frações de textos e pediu que preparássemos narrativas, individualmemte ou em duplas. Eu me encarreguei de um texto literariamente elaborado sobre operários que se apressam na linha de montagem, ganhando tempo para descansar um pouco: "Quando tiver economizado o fabuloso capital de dois ou três minutos, terá tempo de fumar um cigarro voluptuoso capitalista de mãos nos bolsos que olha passar sua carroçaria já soldada enquanto os outros trabalham" (LINHART, 1980, p. 13). E, como minha solução cênica para esse trecho não foi das melhores, o diretor propôs quatro ou cinco movimentos conosco até chegarmos em algo que representaria o trabalho dos operários dentro de uma fábrica. Falou-se que na semana seguinte experimentaríamos objetos como luvas, óculos de solda e similares.

${ }^{116}$ Apocalipse, 20:1-4. Bíblia. São Paulo: Paulus, 1990, p. 1536. 
Ou seja, estava em curso uma busca sobre como representar, com poucos elementos, o ambiente de uma indústria.

Ainda sobre as narrativas repassadas a nós, tanto Érika Rocha e Beatriz Bittencourtcomo Rogério Bandeira e João Filho versaram sobre Malud, um argelino hábil com a solda, igualmente extraído do livro Greve na fábrica:

\begin{abstract}
Com a mão esquerda ele pega um bastão de uma matéria brilhante; com a mão direita, o maçarico. A chama é lançada. Uma parte do bastão funde-se em um montículo de matéria mole na junção das placas de metal. Malud espalha cuidadosamente essa matéria, valendose de uma espátula de madeira que pegou logo após ter lançado o maçarico. A fenda desaparece: agora a parte metálica acima da janela aparece composta de uma peça só. Malud acompanhou o carro dois metros; abandona o trabalho já feito e volta para o seu posto, ao ponto de estacionamento, esperando o seguinte (LINHART, 1979, p. 16-17).
\end{abstract}

As cenas propostas pelos atores a partir do texto acima foram revistas pelo diretor, que procurou criar um jogo de um ator narrar e o outro fazer no ar, em plano alto, sem um carro real, obviamente, a pantomima da habilidade do argelino. Mas, aos poucos, um deles passou a levemente dançar enquanto trabalhava, influenciando o segundo. Essa vertente era a dos sonhos que tínhamos como uma das possibilidades formais da peça. E novamente ouvimos de Sérgio a importância da ênfase no gesto, cujo exemplo foram os sopros que Bandeira tinha dado enquanto acionava um maçarico irreal em seu exercício. Na versão estreada, teríamos uma sequência com um teor distinto, mas não sem relação com a passagem acima.

$3^{\mathrm{a}}$ tarde de ensaios

Recebemos Tin Urbinatti ${ }^{117}$, que participou do movimento político e sindical do período por nós estudado. Como foi um encontro de mais de três horas, apontarei apenas alguns pontos da conversa: antecederam as greves sobre as quais estávamos debruçados os movimentos contra a carestia e o sindical metalúrgico; também fomentaram as mobilizações as comunidades eclesiais de base e organismos de esquerda, como o Partido Comunista do Brasil e a Ação Popular; havia estudantes e militares disfarçados de operários dentro das fábricas; os trabalhadores passavam informações escondidas nos galpões das indústrias. Sem embargo, Urbinatti nos contou histórias de seu tempo de coordenador de atividades culturais no Sindicato dos Metalúrgicos de São Bernardo do Campo, como a ocasião em que, atribulado com muitas tarefas, ele pegou um filme para exibir no cineclube, sem conferir o conteúdo da película. Quando foi projetá-la no espaço de uma igreja, com um lençol servindo

\footnotetext{
${ }^{117}$ Tin Urbinatti dirigiu o Grupo de Teatro Forja, sobre o qual escreveu o livro Peões em cena, em que narra as experiências do Forja durante as grandes greves no ABC.
} 
de tela, aconteceu de uma cena de nudez ter se encaixado com a imagem de Cristo, ficando o seio de uma atriz nas mãos de Jesus, o que criou alguma confusão com o padre da paróquia. Descrevi esse episódio por depois ele ter inspirado uma situação de $O$ pão e a pedra, como veremos mais adiante.

Fomos embora aconselhados para que dirigíssemos nossas atenções a personagens como um operário sindicalista e um ou uma militante do movimento estudantil, preferencialmente atípicos. E que a peça não seria sobre sindicalismo, mas a respeito dos novos padrões que surgiram no final dos anos de 1970. Como a esquerda estava em baixa e os sindicatos eram pragmáticos, reivindicando apenas economicamente, olharíamos de que modo isso influenciou os valores do período e, ainda, qual seria o papel do catolicismo naquele contexto.

$4^{\mathrm{a}}$ manhã/tarde de ensaios

Aos sábados, começávamos os ensaios às dez horas da manhã e a equipe se reunira para discutir a dramaturgia que teria que progredir em vista da estreia dali a dois meses. Apesar do curto prazo, confiávamos que teríamos condições de arquitetar um material satisfatório em sessenta dias, pela experiência adquirida ao longo de quase duas décadas de projetos.

Sobre as cenas preparadas pelo elenco, cito uma imaginada por Helena Albergaria e exibida na parte de fora do nosso estúdio: três mulheres com seus cigarros no que seria um banheiro feminino. Afrouxavam suas roupas, liberando pernas, ombros e parte do tórax. Trocavam e passavam Coca-Cola pelos corpos. Em chave irônica, dizia uma delas: “Tá boa a praia aí?".

A direção recebeu bem a cena pelos gestos sobre os corpos, por um outro uso do refrigerante e com as operárias projetando uma paisagem sobre o vestiário. Essa cena tornouse um referencial entre nós e foi uma das ideias que permaneceu na peça. Albergaria levaria adiante esse seu intento contraditório, destoando privações e lazer.

$5^{\mathrm{a}}$ tarde de ensaios

Como as vezes acontecia, os experimentos mostrados pelos atores não convenceram a direção. Foi quando nos voltamos à linha documental do processo: 
fábrica, aprendendo com os profissionais. E durante o ano inteiro, a indústria paga o seu salário. A segunda vantagem é que Joaquim tem emprego garantido na indústria metalúrgica assim que terminar o aprendizado. E no Brasil, assim como em qualquer outro país, ter emprego é muito importante para todo mundo [...] (Veja, abril de 1979, p. 93).

Pela perspectiva de inserção da juventude brasileira no mundo fabril, testamos cenicamente esse anúncio da Associação Nacional dos Fabricantes dos Veículos Automotores. Entre a reprodução teatral da filmagem de uma publicidade e a simples elocução do texto com um ator mostrando o anúncio impresso, ficamos com a segunda.

Nas conversas finais daquele ensaio, Sérgio de Carvalho reforçou que trouxéssemos cenas com relações pessoais entre os personagens. Que evitássemos o discursivo e priorizássemos os aspectos particulares daquelas figuras. E, ainda, que déssemos conta da troca de papéis sociais e da transformação deles em outros (metamorfoses), das pressões da realidade sobre os indivíduos, sem deixarmos de pensar em seus aprendizados políticos. Fui para casa pensando em como eu poderia responder àqueles chamados.

$6^{\mathrm{a}}$ tarde de ensaios

Com a presença constante dos músicos na sala (Lincoln Antonio e/ou Martin Eikmeier), ativar a voz, cantar e experimentar sonoridades eram ocupações permanentes com uma produção que incluía criações que não necessariamente iriam permanecer no espetáculo. E o mesmo valia para as proposições do elenco: uma porção razoável de ideias ficaria de fora pelo trabalho não comportar tal quantidade de sugestões.

Sobre o aquecimento do dia, conduzido por João Filho, caminhamos pelo espaço e, quando o tambor soasse, formaríamos um piquete, montaríamos uma assembleia e assim por diante. Em meio ao exercício, o diretor assinalou, depois de me ver pegando uma garrafa de água para respingar no rosto de Bandeira como que desmaiado ao chão, que teria sido melhor se eu antes aguardasse internamente um tempo, um instante, para não deixar a ação inverossímil. O meu imediatismo vinha, naquele caso, da falta de um preenchimento ou de uma dúvida ou de uma troca de olhares com algum parceiro na cena. E nesse ensaio, Sérgio começou a falar mais diretamente da atuação, indicando para pensarmos em algum grau de perturbação das personagens que rebatesse em suas ações externas e internas. Estava posta a busca pela dimensionalidade dos papéis em gestação.

Uma outra tarefa que ficara do dia anterior foi a de pensarmos em músicas dos anos 1970 para um jogo de cantar enquanto se faz outra coisa. Proveitosa foi a escolha de Helena Albergaria que, como outros do grupo, escolheu Roberto Carlos. Investida de contramestre, Sérgio sugeriu que ela (fazendo-se passar por um homem) cantasse fino e, assim que alguém 
se aproximasse, engrossasse a voz para explicitar sua masculinidade antes deixada um pouco de lado. Esse detalhe da modulação vocal veio a fazer parte do espetáculo, uma vez que, na nossa ficção, a operária Joana Paixão iria se fazer passar por um homem (João Batista) com o intuito de ter um salário melhor.

E por volta das 17 horas recebemos a visita de Celso Frederico ${ }^{118}$, que, entre outros pontos, legou-nos a sentença: "Foi um daqueles tempos em que a história acelera", a respeito do período que estávamos abordando.

$7^{\mathrm{a}}$ tarde de ensaios

\author{
Trabalhar eu não, eu não \\ trabalhar eu não, eu não \\ Trabalho e não tenho nada \\ Só calo na mão \\ O meu patrão ficou rico \\ e nós fiquemos na mão
}

Lincoln Antonio nos fez dançar e cantar esse batuque de umbigada, além de promover uma sessão em que exploramos as sonoridades de peças de motores de automóveis, chaves de fenda, alicates, utensílios de cozinha e objetos de metal.

$\mathrm{Na}$ sequência, revendo um fragmento proposto anteriormente pelos atores, Carvalho propôs que um trabalhador, ao ser interrompido por outros em uma reunião, teria que absorver as interferências dos companheiros a ponto de ficar em dúvida sobre o que dizia. Sérgio nos pediu para, antes de tudo, ouvirmos, pois não haveria como reagir sem uma escuta sobre o que os parceiros estivessem fazendo, propondo ou dizendo. Que abríssemos mais tempo esperando entender o que nos era direcionado pelos colegas. É o que ele chama de acúmulo: escutar, compreender e só depois responder. Foi-nos recomendado, ainda, que precipitássemos a dimensão subjetiva dos nascentes personagens e que usássemos o mínimo de palavras para que os gestos se sobressaíssem nas improvisações.

Ainda neste ensaio, Sérgio introduziu Fúria Santa, um sujeito que havia quebrado máquinas em um colapso nervoso no seu último emprego. Ele buscaria lucidez, por abalado que fosse. Não demonstraria seu transtorno, mas se empenharia em ser razoável, lutando

\footnotetext{
${ }^{118}$ Sociólogo, autor dos livros A vanguarda operária (São Paulo: Editora Símbolo, 1979 e Consciência operária no Brasil (São Paulo: Editora Ática, 1979). Anotei a frase citada durante a conversa entre C. Frederico e o grupo.
} 
contra o seu distúrbio. Rogério Bandeira foi encarregado de conduzir esse incipiente papel, que já aparecera nos ensaios e se tornaria um dos mais emblemáticos da obra.

Por outro lado, ao representarmos a classe operária, notei que imitávamos (e mal) a sua suposta maneira de falar: um falso sotaque meio nordestino ou interiorano com a supressão do "s" no final de palavras plurais: "os amigo" ou "as visita". No entanto, antes teríamos que captar as razões e os sentimentos dos personagens sem nos preocuparmos com suas caracterizações. Depois que, porventura, conseguíssemos alguma autencidade nas figuras que pouco a pouco vinham ganhando vida, não seria proibido imprimir esse ou aquele modo de falar nas mulheres e nos homens que estávamos corporificando.

$8^{\mathrm{a}}$ tarde de ensaios

Ela pega a sacola e se vai. Ele segura a sacola. Ela retira as coisas de dentro de sacola, colocando-as entre os braços. Ele retira as coisas dela. Ela as deixa e se vai. Ele a pega pelo braço.

ELA: Me deixa, homem. Eu preciso ir.

ELE: Você não vai sair dessa casa para fazer baderna.

(Ela reage em silêncio.)

ELA: Eu não mais vou discutir com você. Minhas companheiras estão me esperando.

ELE: Se você for, eu pego as crianças e vou para a casa da minha mãe.

(Ela fica sem ter o que dizer. Começa a chorar, dizendo:)

ELA: Você não pode fazer isso comigo. Roubar as crianças de mim.

ELE: Então fica em casa.

(Silêncio.)

ELA: Será que você não percebe, João (vai se desfazendo e rearrumando as coisas como quem está desistindo e falando como quem quer convencê-lo), já te falei cem vezes. Se depender deles, nós vamos continuar nessa pobreza e os nossos filhos também serão serviçais de quem dá emprego pra gente. Não é porque você, nós, somos ignorantes que temos que continuar assim. Até o nosso casamento pode acabar João. Nenhum amor aguenta um casal indo da fábrica para casa e da casa para a fábrica, sem poder ir a um cinema no final de semana, jantar fora uma vez por mês ao menos. (Arrumando o que ficou no chão) Eu vou ficar João, porque a sua mãe já tem serviço demais na casa dela - fazer a faxina, cozinhar, lavar a roupa e ainda cuidar do seu pai que está doente. Mas me deixa ao menos avisar minhas amigas aqui da rua que eu não vou.

ELE (Tempo.): O que você vai dizer para elas?

ELA (Tempo.): Que as crianças estão passando muito mal por causa de uma comida que estava estragada. Que estão com diarreia e vomitando.

ELE: Não exagera, isso é mau agouro. 
ELA (Tempo.): Mau agouro é você não deixar sua mulher participar da greve por achar que isso é coisa só de homem. Tem um monte de mulher casada no movimento. Esse seu pensamento é velho, João. Só porque seu pai é assim, você tem que ser igual?

ELE: Vai, Lúcia, vai que não aguento mais você falando.

Mais improvisamos do que seguimos a ordem das frases, pois era impossível memorizá-las de chofre. O que talvez tenha sido melhor, porque Helena colocou outras sentenças, dando mais frescor ao diálogo. Mas assim que terminou, a cena gerou um debate: que lembrava a dramaturgia de Giafrancesco Guarnieri e eu afirmei que, depois que a escrevi, também fiquei com essa sensação. Que havia uma cena parecida, com a mulher grávida até, em Quando as máquinas param, de Plínio Marcos. Eu pontuei que pensei em subjetividade, dado solicitado por Sérgio de Carvalho, relacionando-as com dramas privados e inverti o mais conhecido da mulher em casa e o homem fora. Sérgio pontuou que a personagem estava emfraquecida por ser consciente de precária situação social e que esse modelo de representação poderia afastar o espectador. Ponderei que pretendi refletir sobre o aprendizado dela e Sérgio retribuiu que teríamos que pensar então no processo prático do aprendizado dela, vendo acontecimentos ou descrevendo fatos que tivesse presenciado. E mesmo comigo ponderando que havia pensado na oposição entre o que é dito e o que é feito, com ela desistindo, buscando convencê-lo, seguimos com outras propostas e essa ficou apenas como um bom exercício.

Com o elenco diariamente propondo ideias dramatúrgicas e de encenação, o esperado era que intérpretes tivessem uma compreensão maior do todo do processo. Se eu experimento, ao longo dos ensaios, não apenas o meu papel, mas diversos outros até que se definam quais personagens cada um fará no espetáculo ou se um parceiro pensa em ações e textos para outros e juntos concebemos uma cena, estaremos mais conscientes do transcurso teatral. Em suma, na metodologia em que os atores participam da construção das cenas, a atuação portará consigo a feitura do fenômeno o que, por sua vez, rebaterá na atuação justo por experimentarmos as cenas e as suas origens. Ademais, a colaboração dos atores com a dramaturgia e a encenação de modo algum excluía a operação detalhada sobre cada um dos personagens, através da afinação entre o diretor e o seu time.

$9^{\mathrm{a}}$ manhã/tarde de ensaios

Esticamo-nos e nos alongamos, acordando o corpo naquele sábado pela manhã. Logo depois, jogamos o "um em foco", exercício em que todos andam pela sala e, de fora do jogo, 
alguém bate uma palma e congelamos. O comando pode pedir um, dois ou mais em foco. Se for um, apenas um de nós inicia uma ação e/ou improviso. Se um segundo também passar a improvisar, o que começou congela e, quando um terceiro tomar a iniciativa, o segundo congela de maneira que fique sempre "um em foco". No comando da segunda palma, todos voltam a caminhar pelo espaço. A partir de uma nova palma, se for pedido dois ou três em foco (ou mais), a dinâmica é a de que se entrarem, por exemplo, três em foco, quando um quarto começar a se movimentar, um dos três que estava jogando deve parar. Quer dizer, temos que prestar atenção nas regras do jogo e improvisar segundo uma temática que, no nosso caso, era o contexto do movimento grevista do final de década de 1970 no Brasil.

Em seguida, entre outras modalidades musicais, Lincoln Antonio nos colocou para tocar, dançar e cantar um coco:

\author{
Ô dá-lhe Manuel \\ Ô dá-lhe Manuel \\ Esse coco foi cantado \\ Na barquinha de Noel \\ Ô Manuel
}

Nessa hora, percebi que, ao batermos os pés num ritmo quebrado, tocar os instrumentos e cantar e brincar com os colegas em roda, aquilo se tornara também um treinamento rítmico-corpóreo-vocal. E quando mudamos de coco, saímos em duas filas circundando a sala e cantando:

\footnotetext{
Ô bate marcha

Ô bate o tambor

O meu amor é que me faz

Eu ir à guerra

Subi a serra de avião

O meu coração

É um guerreiro

Treme terra
}

Essa última quadra musical entrou na peça pela voz de Joana Paixão, a personagem que se disfarçava de homem, conduzida pela atriz Helena Albergaria. E foi quando ouvi Sérgio dizendo a Lincoln: “Essa mistura de fábrica com música de raiz pode ser legal, hein?”. 
Com o correr dos dias, reparei que os aquecimentos com jogos e exercícios, e também musicais, se intensificavam, assim como a profusão de cenas concebidas e exibidas pelo elenco. Portanto, a cada encontro a futura peça se projetava e indicativos de como nela poderíamos atuar. Até aquela fase, tínhamos a chave dramática para interpretar a subjetividade dos personagens, narraríamos o que fosse documental e seríamos um ensemble cantando e manipulando objetos de cena.

Mas antes de encerrarmos mais um dia de atividades, recebemos a incumbência de ampliarmos a trajetória dos personagens com três ou mais quadros em cada amostragem de cenas, que utilizássemos passagens da Bíblia e preparássemos trechos em que as nossas figuras delirassem ou vivessem fantasias. E ainda que os personagens fossem influenciados por acontecimentos iminentes como a preparação e a deflagração da greve, pelos piquetes e a repressão a eles e pela ausência do líder (Lula) por dois dias depois da intervenção no sindicato.

O processo prosseguia e todo o coletivo estava imbuído em fazer de $O$ pão e a pedra um lugar para refletir sobre uma fase de avanços na história do Brasil com a greve de 1979 e uma correspondente regressão em curso, em 2016, com a ameaça do impeachment da presidenta Dilma Roussef. Para tanto, pesquisas, trocas, musicalidades, conversas com convidados, cenas e mais cenas vindas da direção, do elenco e de toda a equipe, escritas germinais e a progressiva condução da encenação e dos atores animavam a sala de trabalho rumo à criação da obra.

\subsection{A PRODUÇÃO CÊNICA E DRAMATÚRGICA DA EQUIPE}

$10^{\mathrm{a}}$ tarde de ensaios

Amadureciam as investidas por parte do elenco e, naquele dia, ao menos duas das ideias apresentadas foram absorvidas pelo dramaturgo e diretor Sérgio de Carvalho.

Como eu ainda vinha conduzindo o personagem do padre (depois migrei para o operário veterano Arantes), lancei três possibilidades a respeito do religioso, mas relato apenas a que ficou na peça. Convoquei todos e fizemos uma corrente na qual jogávamos sacos de alimentos de mão em mão para encaixotá-los, enquanto o padre fazia orações que se juntavam às causas dos trabalhadores. Beto Matos se imiscuía entre o pessoal que trabalhava na organização dos donativos e vinha em minha direção, me ameaçando veladamente, como 
se estivesse a mando da repressão. Carvalho assimilou o desenho cênico de mutirão adaptadando-o aos predicados do roteiro e entrelaçando-o com as demais cenas do guião.

Na última amostra da tarde, Helena Albergaria nos apresentou o que pode ter sido uma interpretação realmente contraditória. Vejamos o que retirei do seu caderno de anotações:

OPERÁRIA: Por que você me deu isso?

ESTUDANTE: Eu achei que você ia gostar.

OPERÁRIA: Olha, eu não quero encrenca. Eu tô marcada. Essa cara. Já tive sete empregos.

Muita confusão. Essa minha revolta, nunca deu camisa pra ninguém! Na última fábrica, depois da paralisação, eu fui pra rua. Eu e quarenta e quatro. E aí? Como é que fica?

ESTUDANTE: É, é difícil.

OPERÁRIA: Não, não é difícil! Pra mim é fácil revoltar! O que é difícil para mim é engolir sapo! Eu sou princesa por acaso? O que é que você é?

ESTUDANTE: Operária, como você.

OPERÁRIA: Não é! Olha, tá tudo bem, mas não me entrega mais merda nenhuma, tá? (Vai sair e voltar) Estudante tem que estudar, operário, trabalhar! Ninguém gosta de mulher encrenqueira. Domingo fui visitar meu filho. Ele tá com as freiras. Ele me pediu chiclete Ploc. Eu não tenho grana pro Ploc! Eu não engulo sapo? Eu? Eu trabalho melhor que todo mundo. É só eu ser mais boazinha, certo? Sem marido, morando de favor. O filho no orfanato.

ESTUDANTE: Eu não quero prejudicar ninguém.

OPERÁRIA: Meu cabelo é pintado. Eu achei que ia melhorar a cara de encrenqueira... Não passa na minha frente, que eu não paro mais na máquina. Eu sou gente boa, da paz, tá?

ESTUDANTE: O Zelão falou que você era gente boa, valente.

OPERÁRIA: Eu não sou valente. Eu sou louca. Que mãe larga filho, faz greve e não tem um gato pra puxar o rabo? Eu sou ruim ${ }^{119}$.

O que a personagem de Helena estava recusando eram panfletos políticos repassados pela estudante. Porém, o que mais me interessa é discutir a atuação dialética. Não apenas pelo antagonismo dos dizeres, e sim porque a atriz (e a personagem) agiam na contramão da emissão das palavras. Ao assistir ao diálogo entre as duas, víamos que a revoltada não estava tão certa assim de que não faria mais parte dos movimentos grevistas, apesar das suas

\footnotetext{
119 Os diversos empregos da personagem e o seu envolvimento com as greves foram inspirados em uma entrevista que as atrizes do elenco fizeram com Maria da Paixão, ex-operária (hoje secretária de uma federação sindical) que participou das mobilizações à época e deu o sobrenome ao papel de Helena Albergaria: Joana Paixão. Entre os pormenores observados pela atriz junto à entrevistada, estava o de que a trabalhadora era cuidadosa consigo mesma, como, por exemplo, pintando as unhas. Outro aspecto que ela contou foi o de que, depois dos piquetes, não havia animosidades entre os que aderiam à greve e os que não, contrariando o mais esperado, que seria a oposição entre os dois lados.
} 
afirmações. E que era uma encrenqueira, acreditávamos, embora não tivéssemos certeza se ela fosse mesmo ruim. Quero dizer, no fluxo da improvisação, as oposições estavam internalizadas, atingindo um contraste ao mesmo tempo verossímel e desconfiável. Em alguns casos, a dramaturgia nos traz as contradições, noutros chegamos a elas pela ironia ou comicidade (o que também pode ser positivo). No entanto, a determinação indeterminada como a que aconteceu com a interpretação de Albergaria nem sempre acontece entre nós nas primeiras tentativas. Esse incidente atoral pode ser visto como um estágio em que ao menos uma atriz do grupo já estava operando previamente com a dialética em seus preceitos interpretativos. O recorte proposto pela minha colega foi incorporado à dramaturgia com algumas mudanças para melhor servir à obra.

$11^{\mathrm{a}}$ tarde de ensaios

Depois de uma fase inicial em que todos nós passamos por diversas figuras, estávamos individualizando os papéis, experenciando seus traços. Não podíamos falar em uma construção linear dos personagens em progresso e sim, através de imprevistos dirigidos, de uma composição diversa e paulatina das nossas criações.

Todavia, apesar da evolução dos atores, Sérgio nos lembrou do risco de mal estarmos nos informando a respeito de quem iríamos representar na peça e já estarmos nos fixando em um ou noutro meneio daqueles esboços. Foi nessa mesma conversa que o diretor me endereçou um novo personagem - o velho operário Arantes - e, ainda, que os demais colegas procurassem o oposto de como vinham atuando: que Bandeira explorasse o lado frágil de Fúria Santa, que Helena encontrasse o afetivo na mulher encrenqueira que se disfarça de homem e assim por diante.

Como adendo, pois o ensaio daquela terça-feira já havia terminado, descrevo um teste que foi feito com a atriz Sol Faganello (que depois passou a integrar o elenco), no qual apareceram pormenores pertinentes às questões atorais do grupo. Enquanto eu e Helena ficamos de um lado da sala, Sérgio pediu a Sol que viesse nos cumprimentar de três maneiras: a) esforçando-se para ser uma boa chefa com os funcionários; b) procurando disfarçar a timidez; c) como quem quer parecer calma. Esses três indicativos vinham das práticas que estão descritas no livro La ligne des actions physiques (ver p. 67-68), no entanto com a verve dialética do nosso diretor: chefia bondosa, timidez extrovertida e nervosismo calmo.

$12^{\mathrm{a}}$ tarde de ensaios 
Eram 14 horas e um tanto e todos estávamos às voltas com as cenas que apresentaríamos em seguida. Eu ensaiava com Beatriz na cozinha do espaço, Bandeira recortava trechos dos versos de uma canção, Helena preparava um objeto, João e Érika ocupavam a sala principal tecendo um diálogo. Porém, a iniciativa que mais nos mobilizou naquela tarde foi uma produção de Beto Matos:

Cena 1:

Feitor invade a Pastoral muito nervoso.

FEITOR: Eu vou entrar, sim! Quero falar com os grevistas!

PADRE: Que é isso?

FEITOR: Bênção, padre, mas meu assunto não é com o senhor.

PADRE: É com quem, então?

FEITOR: É com vocês. Eu vim para ajudar na greve.

(Silêncio. Todos atônitos.)

FEITOR: Que foi? Não estamos todos parados? Em greve? Então eu resolvi ajudar. Eu também sou trabalhador como vocês. Vim do interior, trabalhei como peão por muito tempo, esfolei essas mãos. Se agora eu sou feitor, é porque eu me esforcei, porque mereci. Lá na igreja da minha paróquia, padre, sempre me disseram que o trabalho dignifica o homem. Foi o que eu fiz a minha vida toda: trabalho!

OPERÁRIO: Mas ontem você foi trabalhar, que eu sei!

PADRE: Meu filho, você está de cabeça quente, é melhor se acalmar, meditar.

FEITOR: Fui! Porque é o que sei fazer. Trabalhar! E não vou rezar, não, padre. Eu já disse que meu assunto não é com você ou com seu Deus! Eu trabalho para sustentar a minha família. E ontem, enquanto vocês estavam de braços cruzados, eu estava trabalhando, no turno da tarde e da noite. Pra fazer uma lista de quem estava em greve, pra entregar pro patrão. E quando eu cheguei em casa, o meu moleque, o Roberto Carlos, padre, o moleque por quem eu trabalho tanto, o Robertinho não estava lá... Sabe o que é asma? A criança não respira direito, você tem que comprar uma bombinha - cara pra danar - e fazer o moleque respirar aquilo. Então ele fica com a respiração curta, o coração acelerado, roxo igual vocês lá na caldeira. E a bombinha é cara! Você sabia, padre, que uma pessoa pode morrer de asma? Pode morrer, assim, sem respirar, sufocada, como se estivesse afogada fora da água!... Agora eu não tenho mais por que trabalhar! Eu tenho aqui comigo uma lista de quem foi trabalhar ontem. Não tem nada que ficar fazendo piquete. Eu tenho o endereço também. Se vocês quiserem, eu vou junto e a gente faz essa peãozada parar na marra! É isso!

Não é preciso dizer que a proposta de Matos gerou inqueitação. E entre as sugestões para que ela se ampliase, estava a de que a operária (que se traveste de homem) pegaria nas 
mãos a lista dos não grevistas para não ver seu outro eu-homem ser visto como um fura-greve e também por compaixão, uma vez que os que foram trabalhar eram os mais humildes. Reprocessada, a segunda versão do que Beto trouxe evoluiu para:

Cena 2. (Praticamente igual à anterior até o que se segue.)

FEITOR: [...] Eu tenho aqui comigo uma lista com quem foi trabalhar ontem. Não tem nada que ficar fazendo piquete. Eu tenho o endereço também.

OPERÁRIA (Pega a lista.): Mas aqui só estão os operários mais miseráveis. Tem o João que nem banheiro tem, faz as necessidades num buraco no fundo da casa. Eles precisam desse dinheiro! A gente não precisa desta lista! Vamos deixá-los em paz!

OPERÁRIO: Mas a gente pode ir lá e conversar com eles e mostrar que a greve é pra ajudá-los.

No espetáculo, essa intervenção se uniria à cena da organização dos alimentos para o fundo de greve, em uma síntese promovida por Carvalho:

\section{CENA DOS ALIMENTOS}

(Sol e Érika com uma faixa. Bandeira, Ney e João trazem caixas de mantimentos, Thiago com caixas de papelão, começam a preparação.)

MILITANTE: Olha, gente, a faixa que eu pintei.

(Abre faixa em branco)

MÍRIAM (Lendo com dificuldade): "Viva o universalismo proletário".

MILITANTE: É para dizer que a nossa luta é de todos.

IRENE: E por que você não disse?

MILITANTE: Tentei...

PADRE: Vamos, gente, a fila para as doações está enorme. Um produto de cada tipo por caixa. As latas de óleo podem ser duas, porque vieram a mais.

IRENE (Junto a Fúria e Arantes): Eu quero uma bolacha champanhe dessas para mim.

MÍRIAM: Eu também. (Fúria passa dois pacotes de bolacha, que ela esconde.)

JAÍlTON (Entra com boletim.): Olha isso: as empresas, filhas da puta, estão distribuindo boletins falsos, com timbre do sindicato e a assinatura do Lula para que a gente retorne ao trabalho. Olha!

MILITANTE (Aproxima-se para ver.): Eles vão criminalizar essa greve.

JAÍLTON: A diretoria está preparada. Eles sabem de tudo, eles veem tudo.

ARANTES: Padre, eu admiro muito quem tem fé, deve dar um consolo para pessoa, acreditar numa força maior. Mas daí a achar que existe um salvador.

JAÍLTON: Não começa, Arantes.

ARANTES: Rezar na abertura da assembleia, tudo bem. Agora, tem gente chamando dirigente sindical de pai?

JAÍLTON: Não começa, Arantes.

ARANTES: Lula nosso que estais na terra, seja a feita a tua vontade, aqui na Mercedes como nas outras firmas. Não nos deixe furar a greve.

JAÍLTON: É melhor rezar para ele do que se ajoelhar para a Fiesp.

ARANTES: Amém.

JAÍLTON: Amém.

PADRE: A Igreja já tem seus santos. (Sinaliza para começarem.)

(Começa o circuito dos alimentos às caixas. As caixas prontas, o Padre entrega para Jailton, que leva para fora.) 
MÍRIAM: Eu acho que a gente precisa de umas frases novas para a greve: "Trabalhador unido jamais será vencido" já deu.

IRENE: E o que você propõe?

MÍRIAM: Não sei.

IRENE: "Fome - eu sei - que não vou passar."

CORO: Fome, eu sei, que não vou passar. Fome, eu sei, que não vou passar.

MÍRIAM: "Mais escola - menos Coca-Cola."

CORO: Mais escola - menos Coca-Cola.

ARANTES: "Patrão, maldito, escuta o nosso grito.

CORO: Patrão, maldito, escuta o nosso grito.

FÚRIA: "Ajuda - Jesus - aquele que produz."

(Risos.)

FÚRIA: Repete aí!

PADRE: Ajuda irmão, a teu companheiro, não podes servir a Deus e ao dinheiro.

(Entra Joana pela direita.)

PADRE E JOANA: Ajuda irmão, a teu companheiro, não podes servir a Deus...

JOANA (ao Padre): Muito comprido, padre. A bênção, desculpa o atraso. Meu menino já está em casa comigo.

IRENE: Não acredito, pegou o moleque?

JOANA: Peguei, o bichinho tá numa alegria, comeu tanto que não para de peidar.

IRENE: Vou te visitar, me dá o endereço, à noite eu vou.

JOANA: A noite não dá. Vai no domingo, é na Palmares, no beco atrás da escola, a casa 3.

FÚRIA: Joana Paixão de Cristo, desculpe qualquer coisa, visse.

MÍRIAM: Entra na linha, ô 90 estofados.

JOANA: 90 estofados presente. (Fúria joga um pacote para ela.)

MÍRIAM: Vai voltar?

CORO MULHERES: Estofados, presente!

FEITOR (Entra 11h, exaltado.): Eu quero participar.

ARANTES: Cai fora, fura-greve.

FEITOR (com lista na mão): Deixa eu ficar aqui. Eu fui trabalhar, sim, porque é só o que eu sei fazer. A fábrica não está vazia, mas não tem peão, só polícia para todo lado, e eles querem que eu fique interrogando, eu não ando dormindo bem, tenho criança doente, eu quis vir aqui ajudar. Eu trouxe uma lista de quem está indo trabalhar, para ver se a gente consegue parar com tudo. Tem o endereço de todo mundo aqui.

ARANTES: A gente não gosta de dedo-duro de nenhum jeito.

FÚRIA: Fique aí, Mariano, ajude no mutirão.

PADRE: Pode participar, sim, bem-vindo.

JAÍLTON: Dá aqui essa lista. (Joana pega a lista, olha-a.)

JOANA: Padre, aqui só tem os mais coitados. (Narra.) Jeremias Dió, o da mão amputada, que arrasta os filhos para teste em peneira de futebol. O Pedro Moreno, que tem a filha na cadeira de rodas e ganha um dinheirinho indo para a televisão equilibrando escada no queixo, João Batista Natanael, esse não tem ninguém por ele. É atrás dessa gente que vocês querem ir? A gente é polícia dos nossos iguais?

IRENE: Como você conhece a vida deles? (Joana sai.)

(Sol e Bia levam caixas de papelão, Thiago e Érika, mantimentos. Beto fica em cena.) (CARVALHO, 2016, p. 26 e 27 do roteiro de $O$ pão e a pedra $)^{120}$.

Mas antes que o texto acima ganhasse uma forma final, ao fazermos e refazermos a cena de Beto, percebi que Helena assimilara uma recomendação da direção, improvisando opostamente à pressão aos fura-greves, como: "Dona Odete: sete filhos, viúva. Velha que não aguenta mais com um parafuso na mão e trabalha quatorze horas. Eu vou me meter na vida de

\footnotetext{
${ }^{120}$ Até março de 2108, data da conclusão desta pesquisa, o texto de $O$ pão e a pedra não havia sido publicado em livro. Portanto, as nossas citações a ele referem-se ao seu roteiro.
} 
quem bebe o dia inteiro para aguentar o tranco na fábrica? Que está sempre com o miolo louco? Eu vou dar com pau na cabeça dela que quase morreu no último aborto que fez para aguentar ir trabalhar na segunda? Foi sangrando para a fábrica...”.

Já na minha participação, ainda como padre, fui me solidarizar caridosamente com os desprovidos mencionados pela personagem de Helena. Porém, Sérgio viu o contrário: como o padre era avançado, seus dizeres primariam pela emancipação daqueles operários no caminho da luta política e da conscientização coletiva e social. Sua fala não seria de pena, mas de decisão para que os desvalidos se unissem aos demais trabalhadores organizados, em união com a classe explorada. Concordei com ele e comigo pensei que, mesmo depois de quase duas décadas trabalhando com as contradições, nesse caso eu ainda agia dualisticamente.

No entanto, no segmento seguinte, quando João Filho nos incitou a fazermos uma outra cena inspirada no filme $A B C$ da greve, minha postura foi distinta. $\mathrm{O}$ ambiente era o de um dirigente sindical distribuindo panfletos sobre a greve para os trabalhadores em trânsito. Sérgio aproveitou aquela movimentação iniciada por João e redistribuiu as funções, comigo vivendo um trabalhador mais velho. Eu chamava a atenção do jovem sindicalista (João), sendo que Beto Matos atuava como um policial. Foram três tentativas até que fôssemos, em conjunto, entendendo e acertando a união das atitudes corporais com os diálogos. Antes do operário de João ser preso pelo policial de Beto, eu deveria improvisar um aviso a João mantendo o ano em que estávamos inseridos (1979), todavia ecoando o panorama de março de 2016, em que se polarizavam as tramas da direita brasileira e a resistência da esquerda.

VELHO: Essa mobilização de vocês aí não vai dar em nada. Aliás, eu me desliguei do sindicato. Sou macaco velho. Em 68 eu estava no seu lugar. Só que eu aprendi. Agora você toma cuidado, viu? Agitador assim como você pode ficar marcado, visado. É isso que eles querem. Daqui a pouco vem alguém e te arranca dessa proteção dos outros. Cuidado, hein, menino.

Afastando-se como quem quer ficar, condenando o outro com ele se solidarizando, chamando a atenção do companheiro expressando sua própria fragilidade. Foi o início da trajetória do que depois se tornou o meu personagem Arantes: um velho operário que não se alinhava ao sindicato ao mesmo tempo que aderia às mobilizações quando elas se mostravam autênticas.

$13^{\mathrm{a}}$ tarde de ensaios 
A provisória montagem da peça começara. Chegavam pedaços de fuscas para testes cenográficos. Em uma das possibilidades, Beto Matos segurava no ar um paralamas e Rogério Bandeira, acendendo um faiscante bastão oculto por dentro da peça que refletia em seu rosto, simulava os movimentos de um maçarico, enquanto eu narrava, situando a linha de montagem. Em outra frente, dividimo-nos em dois coros nas laterais do espaço enquanto Helena Albergaria e Beto Matos permaneciam no centro do palco, com Beto fazendo bolhas de sabão e Helena furando-as com um pequeno martelo. Lincoln Antonio acompanhava (com o piano alterado para produzir sons incomuns ${ }^{121}$ ) e marcava com notas musicais o desaparecer das bolhas no ar.

Em virtude das manifestações contra um golpe de Estado em andamento em março de 2016, paramos o ensaio mais cedo e fomos todos para a Avenida Paulista. Não haveria como não participarmos da indignação que tomava conta das forças populares do país.

$14^{\mathrm{a}}$ manhã/tarde de ensaios

Os aquecimentos de todos os dias eram essenciais para promover uma pulsação comum. Indiretamente, eles drenavam nossa integração, o que proporcionaria uma maior disposição para o trabalho. Tanto que, por exemplo, passei a escrever em casa dois ou três fragmentos diários, na esperança de que ao menos um fosse aproveitável. Foi o caso do quadro seguinte:

SINDICALISTA: O senhor não vai fazer nada?

VETERANO: O que você quer que eu faça?

SINDICALISTA: Não sei, alguma coisa...

VETERANO: Bater a cabeça na parede até sangrar?

SINDICALISTA: É, já é alguma coisa...

VETERANO: Rapaz, sossega, já estamos presos. Agora é esperar.

SINDICALISTA: Mas quanto tempo nós vamos ficar aqui?

VETERANO: Isso só os advogados do sindicato é que vão saber.

SINDICALISTA: Quer dizer que agora o senhor é do sindicato?

VETERANO: Nada disso. Só que eles vão defender todos que os foram presos.

SINDICALISTA: E se eles defenderem só quem é do sindicato?

VETERANO: O sindicato não é tão mesquinho assim...

SINDICALISTA: Como o senhor...

VETERANO: Cala a boca, rapaz, antes que eu perca a paciência...

\footnotetext{
${ }^{121}$ Lincoln Antonio introduziu parafusos no mecanismo do piano, o que gerou sons metálicos, entre outras intervenções que o maestro fez no instrumento.
} 
SINDICALISTA: Eu aprendi a respeitar os mais velhos, não se preocupe...

(Silêncio.)

VETERANO: Como é que você foi preso?

SINDICALISTA: Eu fui burro. Fui enfrentar a PM de frente, querer argumentar, falar que eles são operários como nós, que também são explorados, que têm mãe como todo mundo. (Faz que leva um golpe e cai.)

VETERANO: Também, você foi falar da mãe deles...

SINDICALISTA: Falei da mãe de todo mundo... E o senhor, como te pegaram?

VETERANO: Eu me entreguei.

SINDICALISTA: Como?

VETERANO: Eu pedi para me levarem. Quando eu vi que estavam pegando vários de nós, eu fui me aproximando, fui me enfiando entre os detidos, coloquei as mãos pra trás, me curvei como se eu tivesse levado porrada, ainda reclamei, indignado, quando me enfiaram no camburão e agora estou aqui.

SINDICALISTA (Sem entender.): O senhor não bate bem da cabeça... Pra que fazer isso?

VETERANO: Não sei direito, não consegui não fazer nada vendo os companheiros sendo presos.

SINDICALISTA: Mas o senhor seria mais útil lá fora, não?

VETERANO: O problema é que nem tudo que a gente faz tem que ser útil. Tem coisa que a gente faz sem pensar, faz por fazer. Até se arrepende depois, mas faz e está feito.

SINDICALISTA: Ô, velho, a hora não é pra filosofia, nós estamos precisando de gente que lute de verdade, que trabalhe para a greve vingar e a gente sair vitorioso pra poder comprar uma roupinha melhor pras crianças e um fogão de quatro bocas. Aí dá para cozinhar o arroz, o feijão e a mistura tudo de uma vez.

VETERANO (Tempo.): Você tem razão. Se a gente sair daqui, eu vou voltar pro sindicato. SINDICALISTA: Não sei se vão querer o senhor lá..

VETERANO (Percebendo algo.): Olha a comida aí.

SINDICALISTA (Se abaixando.)

VETERANO: Pode comer, você está com mais fome do que eu.

SINDICALISTA: Vamos dividir.

Sérgio considerou irreal que meu velho forçasse a si mesmo a ser preso e ocorreu uma conversa em torno daquela minha ideia encenada. Helena sugeriu que um travesti estivesse conosco na prisão e inserimos Beto Matos, que contou, ao final do nosso diálogo, sua dura história. $\mathrm{O}$ diretor comentou que, com a introdução de uma figura que estranhasse a cena, o material poderia ser aproveitado. E quando ele falava em distanciamento naquele caso, era porque a personagem causava estranheza entre os dois trabalhadores que estavam lá por causa da greve, enquanto a figura de Beto vivia em condições ainda piores. 
Eu procurava, por todos os lados, injetar a contradição no meu veterano, ainda que, nesse caso, esbarrasse na incongruência. Por sua vez, é de se notar que minhas investidas se limitavam a diálogos, sem o aproveitamento de formas narradas (visuais ou verbais), o que se pode ver como uma tendência ainda de representar mais pela dramática do que pela épica. Iria chegar o momento em que eu estaria mais próximo dos contrários na atuação em $O$ pão e a pedra.

$15^{\mathrm{a}}$ tarde de ensaios

Ficamos um dia sem ensaiar para que Sérgio de Carvalho organizasse uma primeira versão do roteiro. Quando retornamos, como aquecimento, Helena Albergaria nos colocou para dançar ao estilo de música disco dos anos de 1970, com todos seguindo os passos de um puxador. Em determinado ponto da brincadeira, nós, homens, nos encostamos na parede com as mãos para cima e as mulheres simularam uma revista policial, o que fez com que o diretor visse naquilo uma boa sugestão para se realizar uma transição da cena da festa para o confronto com a polícia - passagens previstas até então no pré-roteiro elaborado por Carvalho.

Contudo, os vetores vinham se cruzando cada vez mais com a reutilização, por parte da direção, das ações do que os atores traziam aos ensaios. E já se improvisava de acordo com os indicativos que auxiliariam a arquitetura cênica em elaboração. Circunscreviam-se os olhares da equipe diretiva e do elenco para um campo comum, visto que uma nova etapa se avizinhava: a dramaturgia tinha em mãos uma primeira lista de cenas no papel.

Uma aproximação da compreensão do que nos era solicitado e do que devolvíamos pode ser vista a seguir:

\section{NA ASSEMBLEIA.}

VELHO (Enquanto ele fala, quem está perto tenta impedi-lo.): Eu não aceito essa negociação, vocês estão mancomunados com a Fiesp, com o Ministério do Trabalho. Abaixo essa diretoria, viva a livre organização dos trabalhadores. Quem não acredita nesses que estão no palanque que me sigam! Vamos nos encontrar lá fora e continuar a greve! Essa trégua é uma manobra pra despistar a gente. Tá todo mundo aqui querendo continuar a greve, ninguém quer parar a mobilização.

(Como se ouvissem Lula pedindo um voto de confiança, porque ele mesmo seria o primeiro a entrar em greve, caso as reivindicações não fossem atendidas.)

VELHO: Não, senhor! Vocês só pensam no sindicato. Por acaso essa massa de gente aqui realmente precisa do sindicato pra fazer greve? E se o sindicato fala uma coisa aqui e outra 
quando se reúne com os patrões? É meia dúzia da diretoria que senta pra negociar com os donos das firmas.

JOÃO: Chega, Arantes! Pode ir lá pra fora que nem meia dúzia vai atrás de você. Para de atrapalhar a assembleia e deixa eles falarem. Ninguém aqui acha que essa diretoria trai a gente. (Sinais e dizeres de “não, não...”.) Então, vocês aí de cima, podem continuar que o nosso amigo aqui vai ficar quietinho.

OPERÁRIO 1: Mas eu não vou ficar, não. (Sons de "Ô̂ôo" - de impaciência...) Podem vaiar que eu não me importo. Mas o companheiro Arantes não deixa de ter razão em algumas coisas. Por que o sindicato não quer se unir aos estudantes e aos intelectuais? São pessoas lutadoras como nós e só querem o nosso bem. O movimento só vai crescer com mais gente. (Como se do palanque alguém dissesse que a luta dos metalúrgicos era por melhores salários para as famílias e não sobre política.)

OPERÁRIO 2: É isso mesmo, o negócio é a gente melhorar as nossas vidas. Mais comida, uns aparelhos lá pra casa, um fusca um dia e pronto!

(Arantes vai saindo do meio deles. A estudante vai atrás dele:)

ESTUDANTE: Arantes, espera. Tem muita gente aqui que pensa como você.

VELHO: É, mas quem tá lá cima é muito habilidoso. Ele vai acabar convencendo a maioria a voltar ao trabalho. Não tem jeito. E eu ainda me queimei sendo afobado. Me falta estratégia. Ser explosivo não leva a nada...

ESTUDANTE 3: Deixa eu te pagar um Guaraná então.

VELHO: Guaraná? Mas nem a pau, só se for uma Coca-Cola...

ESTUDANTE 3: Tá bem. Um Guaraná pra mim e uma Coca pro senhor.

A direção pediu que refizéssemos a cena, com aproveitamento de parte do texto, principalmente sobre as contestações contra quem estaria discursando na assembleia e com João Filho me questionando em defesa do sindicato. Nós reelaborávamos o que nos era pedido e a dramaturgia refazia o que propúnhamos. Campos e contracampos se entecruzavam em função de um projeto em progresso.

Findo aquele ensaio, Sérgio nos apresentou um roteiro com 21 cenas. Algumas pinçadas do que nós, atores, havíamos mostrado, outras de sua lavra. Tínhamos uma estrutura - mutável, sem dúvida, mas uma base para prosseguirmos. E nos convocou a trazer mais cenas, especialmente as posteriores à grande assembleia que decidiria pela volta ao trabalho com uma trégua de 45 dias na greve. Reforçou que pensássemos em lances gestuais, dando Judas como modelo: “Aquele que eu beijar, é ele”. Um ato simples, afável e que, a contrapelo, guardava uma traição. Fomos embora com o estímulo de que Brecht retirava da Bíblia contradições como aquela. 
$16^{\mathrm{a}}$ tarde de ensaios

Lincoln Antonio nos trouxe uma nova música para aprendermos. Eis sua letra:

\author{
Depois de várias reuniões com os patrões \\ verificamos que eles não querem conceder nada \\ Por isso, nossa assembleia decretou: \\ greve geral nessa terça-feira \\ (Fala) Essa é a única linguagem que os patrões entendem \\ Máquinas paradas \\ só voltarão a rodar quando conseguirmos \\ $34 \%$ acima do aumento do governo, \\ estabilidade do emprego, \\ reajuste salarial a cada três meses, \\ fim das perseguições e dispensas arbitrárias, \\ delegado sindical com estabilidade, \\ e piso de três salários mínimos \\ (Fala) Companheiros e companheiras, nossa palavra de ordem é: \\ lutar, lutar, lutar, até a vitória (2x)
}

A melodia e o estilo falado eram semelhantes aos da primeira canção da peça que o maestro vinha ensaiando conosco, só que nesse caso os dizeres vinham da pauta da greve do $\mathrm{ABC}$ e não de trechos do livro do francês Linhart. Manufatura musical, produção cênica, maquinações atorais. As trocas se intensificavam e, naquele tempo, havia uma motivação constante em toda a equipe. Não só trabalhávamos intensamente na sala como fora dela. Trocávamos informações e ideias por correio eletrônico, antecipando o que iríamos produzir no estúdio, de modo que a inquietação criativa extrapolava os horários agendados. Ensaiar era uma das partes entre estudar, escrever ou planificar as cenas, para mais das seis horas diárias de trabalho. Daqueles períodos de teatro em grupo que se guardam, pois não é sempre que podemos nos dedicar a um processo artístico com tanta disponibilidade.

$17^{\mathrm{a}}$ tarde de ensaios

Se quando encenamos um texto já escrito buscamos, como intérpretes, preencher com a imaginação episódios que não constam na dramaturgia para que tenhamos uma visão mais ampla dos personagens, no processo de $O$ pão e a pedra, como em outros do grupo em que as escritas foram urdidas nas salas de trabalho, a abertura para cenas extraroteiro estava posta. De modo que tudo o que vínhamos fazendo dia após dia, de uma maneira ou de outra, 
colaborava para a espessura dos papéis e dos atores que estavam percorrendo o maior espectro de possibilidades sobre o universo abordado. Nessas amostras preparadas pelo elenco, os personagens contracenavam em variados episódios, vivenciavam movimentos próximos e distantes do centro das ações concebidas pela dramaturgia e assim progressivamente iam se constituindo.

Encerrando a semana, recebemos a recomendação de continuarmos a trazer novos quadros para o próximo ensaio, mesmo que estivesse se aproximando o momento de começarmos a experimentar as cenas roteirizadas por Sérgio de Carvalho. E que não deixássemos de contimuar a estudar os filmes, livros e reportagens da época, repassados pelos pesquisadores.

$18^{\mathrm{a}}$ tarde de ensaios

Em uma das apostas daquela tarde, Sol Faganello usou o áudio de um discurso de Lula, enquanto nós, olhando para a frente e para o alto, gesticulávamos lentamente as reações à fala do líder. Como as figuras de Sol e João acabavam o exercício mais emocionados, Sérgio repetiu a cena mudando a gravação para um polêmico discurso de Lula no qual ele convence os trabalhadores a interromperem a greve e fazerem uma trégua, com cada um dos atores saindo aos poucos do bloco, restando apenas Sol e João comovidos. Algo parecido veríamos na última cena do primeiro ato do espetáculo estreado. Porém, houve uma discussão na equipe sobre Lula não fazer parte da peça e sim o operariado se organizando em torno das greves. A questão delicada naqueles dias (março de 2016) era a ameaça do Judiciário em prendê-lo, sendo que isso era um dos motivos pelos quais estavam acontecendo grandes manifestações à direita e à esquerda no país.

Quanto à interpretação, o diretor comentou sobre os personagens virem a ter falhas, serem hesitantes, sem consciência plena. E usou como exemplo a frase: "Eu tento falar melhor porque gaguejo". Ou seja, os papéis teriam problemas mais concretos do que ideológicos. E que as ações físicas teriam que sair em direção aos outros e não para si. "Tome, pegue o meu paletó", disse Sérgio ilustrando. Por fim, que a obra optaria pelos atores construindo e desfazendo as cenas, semelhante à lida dos operários. E que procurássemos o sentimento da atualidade: de manipulação da mídia, de subtração da legalidade, de acuamento das forças sociais progressistas, de obscurantismo e medo.

$19^{\mathrm{a}}$ manhã/tarde de ensaios 
No terceiro sábado de trabalho, Helena Albergaria montou, com a ajuda dos pesquisadores, uma projeção com partes do filme 1900, de Bernardo Bertolucci. Essa ideia era fruto da conversa que Tin Urbinatti havia tido conosco, conforme vimos no início deste capítulo. O longa-metragem tinha passagens dramáticas e também eróticas, o que servia ao propósito de gerar um cômico desconforto em sua exibição numa igreja. No entanto, Sérgio interveio colocando Sol Faganello (no papel da estudante integrada) mediando o filme para os presentes. A conjunção de tela, de uma espécie de dublagem ao vivo, somada à adesão do padre e aos comentários da plateia do filme (os nossos personagens), reuniu elementos para que a proposta viesse a fazer parte da obra.

Por minha vez, intrigado em não conseguir criar um acontecimento cênico contraditório, listei o que um homem normalmente faria na década de 1970 e achei que estar em uma barbearia ou no futebol ou em um bar seria comum. Foi então que inverti o ângulo e pensei em lavar roupas. Foi nesse ponto que encontrei um mote para o personagem Arantes: cozinhava, faxinava e, por economia, tudo sozinho fazia as tarefas domésticas de sua casa. Então pesquisei quais músicas eram ouvidas à época e, entre elas, estavam as de Roberto Carlos. A paisagem para a cena se formara:

O meu veterano estaria ao tanque e no rádio tocava "As flores do jardim da nossa casa". Chegavam, um a um, seus conhecidos, sendo que um deles viera pegar a roupa limpa e passada e os outros as deixariam para que ele as lavasse. A ideia era relacionar as canções de Roberto Carlos (que eles pareciam conhecer tão bem, como os homens que sabem muito sobre futebol) com as perdas que aqueles operários haviam sofrido. Eles seriam contrários à interrupção da greve pela trégua e aquele era um momento de retrocesso para eles. Mostramos a cena e avaliei positivamente o material apresentado, porque creio ter alcançado o que vinha tendo dificuldade em articular: a cena continha o gestual solicitado pelo diretor (o lavar a roupa e lidar com as trouxas dos visitantes), o texto vinha mais das músicas do que somente de palavras e estávamos nos esforçando em cantar para esconder uma grande decepção (o cancelamento da greve contra a nossa vontade). Essa última instância talvez tenha ficado mais na intenção do que na realização, por não ser de imediata identificação. E, como já vimos anteriormente, ela fazia parte do nosso intento atuativo dialético: aquele que está triste quer parecer alegre.

Todavia, Sérgio levantou-se, veio até nós e pediu que ficássemos eu e Rogério Bandeira no espaço. Orientou-nos para que ele relembrasse romanticamente o encontro de Fúria Santa com Joana Paixão (a operária de Helena), enquanto eu cantaria "Sentado à beira do caminho", também de Roberto Carlos. Fomos discutindo e transformando a cena, seguindo 
as indicações da direção. Era como se estivéssemos compondo a dramaturgia em conjunto com a encenação e a interpretação, ali mesmo no set dos ensaios. Particularmente, quando esse fenômeno floresce, fico satisfeito por tomar parte desse despojamento criativo: como se precisássemos apenas de nós e mais nada para fazer surgir a arte. Com mudanças, a cena no quintal de Arantes entrou na peça, conjugada a posições de outros personagens da fábula.

A partir da possibildade de um final melancólico para o espetáculo, conversamos a respeito dos posicionamentos na equipe. Houve quem disesse que seria difícil defender o sindicato (que simbolizava o do $\mathrm{ABC}$, mas não era uma réplica dele), assim como criticá-lo. Para ampliar o problema, fazia-se necessário aumentar a pressão de orgãos como a Fiesp (Federação das Indústrias do Estado de São Paulo) ou a repressão ao movimento dos grevistas, evidenciando a politização da classe operária daquele período. Outro contraponto a uma visão negativa, mas real, seria dado pela nossa atitude de deslindar o tema. Isto é, a forma da peça conteria a esperança que o assunto subtrairia. Que tanto haveria espaço para quando os trabalhadores se tornaram mais donos do seu tempo (durante as greves) como para quando se deu uma perda da autonomia conquistada. $\mathrm{O}$ desacordo estaria em revelar a força genuína do proletariado brasileiro ao reiniciar reinvidicações interrompidas pela ditatura e sua subsequente institucionalização sindical.

E como estávamos a 34 dias da estreia, era preciso aumentar o tempo dos ensaios. Porém, isso não significaria interromper o processo criativo e colaborativo por um meio taylorista de ensaiar, com o diretor distribuindo textos e determinando as marcações dos atores pelo espaço. Se, até aquele sábado, vínhamos produzindo (e muito) desorganizadamente organizados, continuaríamos nos arriscando em escambos entre o elenco e a direção/dramaturgia.

$20^{\mathrm{a}}$ tarde de ensaios

Continuavam as buscas por uma síntese do que seria uma linha de produção, já que as proposições anteriores não traduziam teatralmente o funcionamento de uma fábrica. Também o texto (que ainda não conhecíamos), segundo Sérgio, estava grosso e teríamos que descobrir a dicção dos personagens, suas sintaxes e estilos. Que as cenas coletivas estavam menos opacas enquanto as de inter-relações entre os papéis careciam de mais trabalho. No geral, Carvalho considerava aquele estágio da dramaturgia como um conjunto de esboços, mas que dali a dois dias iríamos iniciar uma nova fase, partindo dos escritos que ele nos forneceria. Até lá, deveríamos pensar em quadros sem palavras, com mais de duas pessoas em cena e 
continuar buscando os gestos de cada célula a ser pensada e criada pelo elenco. Como modelo, que tivéssemos em mente o lava-pés bíblico: um ato já começado.

$21^{\mathrm{a}}$ tarde de ensaios

De acordo com o que havia sido solicitado, trouxemos para a sala fragmentos não verbais. Entretanto, o diretor considerou que aquelas breves intervenções serviriam como passagens e que teríamos que respeitar os tempos de compreensão interna das reações. Como quando João Filho recebia uma roupa e a devolvia por não entender direito o que se passava. Porém na segunda vez ele entendia a indisposição dos outros com ele e, depois de perceber isso, largava-a no chão antes de ir embora. Esse intervalo da percepção é que seria importante para evitar imediatismos que não levassem em conta o tempo de elaboração das respostas. Infortúnio atoral similar ao de acionar precipitadamente as emoções, borrando o entendimento do problema em jogo.

\subsection{AS DEVOLUTIVAS DO DRAMATURGO E DIRETOR AO TRABALHO DO GRUPO}

$22^{\mathrm{a}}$ tarde de ensaios

Chegavam os textos escritos por Sérgio de Carvalho, derivados do que improvisamos e da própria pena do dramaturgo. Enquanto líamos aquelas primeiras páginas, transcrevi algumas recomendações:

- Que evitássemos a harmonização entre texto e ritmo cênico. Um cuidado para que a interpretação tivesse autonomia e não se rendesse facilmente à música, à luz ou a quaisquer outros elementos externos às intenções dos personagens. Caso contrário, bastaria que ouvíssemos uma sonoridade suave para que a nossa voz também se adoçasse ou uma luz escura que nos fizesse soturnos em cena.

- Que tínhamos que procurar as palavras antes de dizê-las, senão elas já estariam prontas em nós e, portanto, artificiais, textuais.

- Que não sabíamos de antemão o que iriam nos dizer em cena como personagens, apesar de sabermos como atores. Era preciso ouvir e compreender, para só então replicar.

- Que Beto Matos, ao se passar pelo feitor, estaria cabisbaixo e por isso se empenharia em ser altivo.

$23^{\mathrm{a}}$ tarde de ensaios 
Avolumava-se o trabalho musical, com as canções sendo inseridas na montagem. Lincoln Antônio pediu para que as cantássemos no palco e em nossas funções. Quero dizer, se em uma determinada melodia uma atriz ou um ator cantava sozinho uma parte da canção, já era tempo de seguirmos como supostamente iríamos fazer no espetáculo em preparo.

Podemos dizer que, àquela altura, transitávamos entre quando preparávamos e apresentávamos livremente as cenas para a direção e os ensaios em que tivéssemos firmados os textos. Ou seja, encenando o que agora estava escrito, aferíamos o que estava bom ou não. E quando Carvalho considerava que textualmente uma cena se mostrava assertiva, ele então pedia que a memorizássemos.

$24^{\mathrm{a}}$ tarde

Naquela quinta-feira, dedicamo-nos a uma intersecção entre texto e música, retratando na peça o momento posterior à questionável decisão de se fazer uma trégua na greve. Era um ensaio perseguidor de uma forma para a encenação, mesmo que depois ela viesse a sofrer alterações. Atoralmente falando, ouvi uma indicação do diretor ao meu colega João Filho sobre quando ele ocupava o centro do palco tentando convencer os operários de que as mobilizações continuariam, mesmo com uma interrupção na paralisação: "Bancar ficar só em cena, sem fazer nada". Para que ele, ao ser abandonado pelos companheiros, não se debatesse. Do que podemos nos perguntar se sempre temos que fazer algo o tempo todo no palco e se apenas respirar em situação fictícia não é teatral.

Em seguida, observei a direção do encontro das mulheres no banheiro da fábrica, uma vez que as atrizes praticamente já sabiam aquele texto. Entre as recomendações, estavam:

- Que aquela cena teria um teor tcheckhoviano e por isso seria preciso deixar mais claro o que corria por debaixo dela, como seus correspondentes subtextos.

- Que elas estariam exaustas depois de horas de trabalho, ou seja, seria importante reconstituir o que aconteceu antes daquele momento.

- Que Érika Rocha deveria ter em mente o tempo todo que o que fazia e dizia estava em função da sua gravidez como Irene (sua personagem), revelada a certa altura da cena.

- Que haveria uma inflexão para Sol Faganello (que representava Luísa, a estudante que se fazia passar por uma operária): no momento em que Helena Albergaria (Joana Paixão, a operária muito produtiva, mas desajustada) questionava por que Luísa distribuía um panfleto de sua corrente política. Antes de ela responder - "Eu quero contribuir" -, haveria um instante de reflexão por parte da estudande/operária, uma vez que se descortinava que Joana Paixão já 
sabia que ela não era só uma trabalhadora, com Luísa simultaneamente tendo que pensar em uma resposta objetiva à pergunta de Joana.

- Que Joana dispararia um jorro de frases sobre ela mesma e seu filho para cima de Luísa, porém de uma forma não linear, como quem desarranja em falas do personagem o que estava arranjado em textos.

- Que Beatriz Bittencourt trataria o banho de sol (que entrava pela janela do banheiro), para se bronzear com Coca-Cola, como um acontecimento extraordinário e não corriqueiro.

- Que deveria ficar claro para elas por que entrar em cena.

Ou melhor, estava a dramaturgia ganhando outro perfil com, por exemplo, o trecho acima reunindo reinvenções, por parte do escritor, de dois episódios propostos anteriormente por Helena Albergaria: o do bronzeamento com Coca-Cola e o do desabafo de Joana Paixão. E uma direção cada vez mais específica sobre cada intérprete se relacionando com o seu e os demais papéis. O que se avizinhava era uma etapa de acabamento (sempre inacabado) nos ensaios.

Terminamos o dia lendo novas cenas do roteiro em definição e com isso conhecemos metade da peça. Porém, o nosso trabalho continuaria em casa, memorizando o que já fora revisado pelo nosso dramaturgo e diretor e pensando em novas intervenções.

$25^{\mathrm{a}}$ tarde de ensaios

Cantar, percorrendo o espaço e retomando o pouco que tínhamos desenhado como movimentação cênica para as músicas, vinha se tornando uma prática diária e foi o que fizemos naquela sexta-feira. Com o piano cada vez mais modificado para causar estranhezas sonoras, Lincoln Antônio ainda se cercava de outros instrumentos percussivos, a fim de aumentar as possibilidades da sonoplastia e da musicalização da peça. Continuando, de uma passagem (que depois foi suprimida) em que Joana Paixão era observada por suas companheiras que a estranhavam trabalhando antes mesmo do turno da manhã começar, escrevi:

- Que se todas estavam melancólicas, era preciso distinguir as particularidades da melancolia de cada uma, para que a aquilo não se transformasse em uma "cena estado", com as personagens na mesma conformidade.

- Que seria preciso definir quem seriam as interlocutoras de cada ação, verbal ou não, a fim de evitar que as personagens falassem para o ar, com exceção dos instantes em que elas realmente diriam algo para si mesmas. 
- Não fazer de conta que se estava agindo, mas realmente realizar as ações em cena: ao desenrolar fios ou carregar uma caixa, envolver-se e não apenas fazer com que elas servissem de falsos apoios para a emissão de textos. E quando não tiver nada para fazer em cena, simplesmente dizer as frases.

- Percebi que até hoje temos dificuldade em atuar não seguindo as convenções teatrais tradicionais, como evitar dar as costas ao público e nos posicionarmos em uma angulação que favoreça sermos mais bem-vistos pelos espectadores (o que é conhecido entre nós como três quartos). E isso tanto os mais velhos como eu, que vêm recebendo indicações contrárias a tais maneiras há um bom tempo, quanto os mais novos do elenco.

- Que as ações são mais importantes que as palavras, e estas são uma consequência dos atos.

- Que, por vezes, agimos por impulsos confundindo-os com a energia necessária para as cenas. O ímpeto tem que ser dosado, pois os impulsos se esvaem tão rapidamente como vieram.

- Que as operárias recebiam, ao final do quadro, envelopes com valores contendo os seus salários. Era recomendável que conferissem o conteúdo, visto que a fábrica descontava vários itens dos pagamentos e que, portanto, elas checariam as quantias, valorizando os detalhes na interpretação.

$26^{\mathrm{a}}$ manhã/tarde

Naquele sábado, reparei:

- Que a partir de um discurso do sindicalista em formação (personagem de João Filho), o diretor pediu que seus gestos não saíssem antes das palavras, segundo o encadeamento: primeiro viriam as imagens, das imagens as palavras e das palavras os gestos.

- Que, em celebração à deflagração da greve, eu teria que cuidar para não dividir o texto abaixo, de acordo com os intervalos que eu estava dando em uns passos de dança. Para que eu fluísse com as frases independentemente de como viesse a dançar:

"E Lênin ia dançar assim, se estivesse aqui na Vila Euclides, como dançou na praça em Moscou quando a Revolução ultrapassou os 73 dias da Comuna de Paris. E eu agora vou dançar todos os dias, pois já tenho idade para saber quando uma coisa é boa e dura pouco" (CARVALHO, 2016, p. 17) ${ }^{122}$.

\footnotetext{
${ }^{122}$ Até janeiro de 2018, o texto de O pão e a pedra não fora publicado em livro. Portanto, as citações contidas neste trabalho se referem ao roteiro cuja assinatura final é de Sérgio de Cavalho.
} 
- Que me senti um pouco mais à vontade, deixando de lado as folhas de papel com os textos das cenas que tinha que decorar e me arriscando a vivenciar Arantes.

Porém, aquele foi um ensaio no qual nos dedicamos aos coros e às movimentações em torno da greve, por serem os mais difíceis de se ensaiar, se comparados às cenas da vida privada dos personagens.

$27^{\mathrm{a}}$ tarde de ensaios

Sérgio conferia conosco se o que ele tinha redigido fazia sentido ou não e no próprio ensaio corrigia, cortava, acrescentava, ouvia opiniões e sugestões da equipe, reelaborando o que estava sendo experimentado. Em função disso, ouvi o diretor comentando com Rogério Bandeira: "Cada peça tem um jeito de nascer e esta parece surgir aos pedaços, de fora para dentro". Creio ter sido este um comentário sobre um processo que vinha do geral (cenas coletivas com o trabalho operário e as mobilizações em torno da greve) ao particular (retratos da vida pessoal dos trabalhadores). Nesse sentido, teríamos que estar atentos a:

- Que os papéis guardassem subjetividades gestuais e os exemplos seriam o bronzeamento com Coca-Cola das operárias e Arantes lavando roupa.

- No caso de um piquete, que as dificuldades estariam nas duas pontas: no fura-greve, que não teria tanta certeza assim do que estava fazendo e nos grevistas piqueteiros, que não seriam um bloco inflexível somente contra os que queriam trabalhar.

$28^{\mathrm{a}}$ tarde de ensaios

Recebemos Thiago França, músico e ator, que passaria a integrar o elenco. E, na mesma tarde, durante o ensaio da cena do piquete, Rogério Bandeira, como o antes violento e agora religioso Fúria Santa, buscando não agredir um trabalhador (Thiago) contrário ao movimento grevista, depois de tentar convencê-lo três vezes ou mais, acabava por clamar diante dele: "O que nós estamos tentando é dizer o seguinte: usa a sua consciência, ela é de todos, está aí no ar. Precisa subir no cume da montanha (ajoelha-se), e se olhar embaixo, se ver, lá, 'abandonei meus irmãos no deserto', covarde, então aprende a olhar o mundo do alto" (CARVALHO, 2015, p. 56 do roteiro). O ajoelhar-se tornou-se o gestus da cena, visto que, depois dessa atitude física, a ação mudava de patamar, transformando algo que poderia ser comum em um fato extraordinário.

Sérgio ainda nos relembrou que, em determinados momentos, falássemos como quem cita, não dramatizando em excesso as situações e confiando que esse modo de representar não 
suprimiria as emoções dos papéis. E nos deu uma tarefa para aguçar a contradição: criar um riso de diversão como uma pequena vitória e um choro de alegria.

$29^{\mathrm{a}}$ tarde de ensaios

Naquela dia, por estar mais ocupado com as tarefas atorais, só consegui resgatar:

- Que não nos adiantássemos para falar. Tanto fisicamente (dar passos para dizer um texto) quanto oralmente, sempre respeitando o tempo da repercussão interna causada pela interpelação de alguém sobre nós.

- Que teríamos que definir as ações dos personagens para que a direção pudesse acatar ou não as nossas escolhas.

- Que a relação com os objetos primaria pela simplicidade e verossimilhança. Ao pegarmos um copo em cena, levarmos em conta os diversos pequenos passos que na vida fazemos até bebermos o que ele contém. Esperar o copo se encher, percebê-lo cheio, levá-lo à boca e dar um ou mais goles. Em suma, não tratar os objetos de cena como acessórios sem importância.

- Que, em alguns casos, textos mais longos para uma atriz ou ator não pedem uma abordagem naturalista. $\mathrm{O}$ intérprete pode fazer uma reunião de imagens interrompidas e não necessariamente um encadeamento lógico como seria o esperado.

$30^{\mathrm{a}}$ tarde de ensaios

Como já havíamos trabalhado um pouco sobre as primeiras cenas redigidas, na sextafeira nos voltamos para as de número treze e quatorze do roteiro de $O$ pão e a pedra. A treze, inspirada na cena cinco da peça $A$ mãe, de Bertolt Brecht (que por sua vez foi inspirada no romance de mesmo nome de Máximo Gorki), descrevia narrativamente o confronto dos grevistas com a polícia, alternando relatos e imagens do conflito. “Com o épico é possível criar a subjetividade pelas narrativas e assim emocionar até mais do que com a forma dramática" - comentou Sérgio. Uma consideração que contraria o consenso de que a epicização tem como veio a dimensão objetiva e a dramatização, o subjetivo e o emocional. Vejamos, apenas com a leitura de um trecho dela, se podemos confirmar o que acima levantamos:

MILITANTE (pega cartaz e narra): Eu seguro um cartaz em que está escrita a antiga frase: você é trabalhador como nós. Dois policiais vêm até mim. Um deles arranca o cartaz e o joga no chão (deixa cartaz), o outro me arrasta pelo cabelo (pega próprio cabelo). Eu grito de dor. Avisto um grupo de mulheres que vêm para me defender (CARVALHO, 2016, p. 37 do roteiro). 
Tratava-se de um sentimento sobre uma coletividade, com o indivíduo inserido em um contexto maior, mas nem por isso menos envolvente. Senti algo correspondente lendo o já citado L'Établi, do francês Robert Linhart, traduzido para o português como Greve na fábrica. Conhecia algumas partes do livro que vinham sendo utilizadas pela dramaturgia e pelas canções da peça. Porém, ao conhecê-lo na íntegra, tive uma visão mais completa do funcionamento de uma fábrica. E foi impossível não associar a figura de Simon ao meu Arantes:

O homem tem uma fronte larga, descoberta, cabelos quase brancos: acho-o com cara de mestre-escola ou professor. Está vestido com um macacão azul velho e usado. Rápido, passa com destreza de um carrinho a outro, lançando umas olhadinhas vivas em torno de si. Não há tempo para conversa, ela já se foi com seu carregamento de capotas (LINHART, 1980, p. 41).

Essa descrição de um trabalhador real me auxiliou na materialização dos contornos do meu personagem, ainda embrionário naquela fase dos ensaios. Outra peculiaridade sobre a leitura foi a de uma familiarização junto a certas passagens do roteiro que vínhamos experimentando. A visualização de um ou outro setor da produção de uma indústria de automóveis ganhava maior nitidez com a aproximação ao livro:

Todas as peças sobressalentes (portas, capotas, para-lamas, cofres) vêm da oficina de pintura à oficina da grande linha numa espécie de cabo aéreo: tenho de desenganchar cada peça que chega, verificar se tem defeito de pintura (arranhão, "lágrima" ou escorrimento) e colocá-la num carrinho apropriado (um para os para-lamas da direita, outro para os paralamas da esquerda, um terceiro para as capotas, etc.) (LINHART, 1980, p. 41).

A partir dessas frases e de fotografias de galpões fabris que colhi, passei a fazer desenhos do meu habitat de trabalho. O que, acredito, subsidiava-me nos ensaios, aumentando minha capacidade de apropriação e incorporação do unviverso que estávamos pesquisando. Isso tudo sem esquecer do prazer de ler um livro bem escrito e com valores humanos reconhecíveis. São tais descobertas que nos alimentam como atores e fazem do teatro uma fonte de aprendizagem. Mas os preparos prosseguiam e deles retirei as recomendações:

- Que ao narrarmos certos textos, teríamos que compor imageticamente aquilo a que nos referíamos verbalmente. 
- Que já poderíamos criar distinções entre narrativas do ponto de vista dos personagens, em alguns casos, e, em outros, como narradores da obra como um todo.

- Que seria importante observar os outros, pois é deles que vem a nossa reação. Deixar-se afetar mais pelo que se ouve do que pelo que se fala.

$31^{\mathrm{a}}$ manhã/tarde de ensaios

Não pude ensaiar naquele sábado porque fiquei muito gripado.

$32^{\mathrm{a}}$ tarde de ensaios

Estávamos cumprindo uma agenda diária que incluía primeiramente o trabalho musical - aquecimento, cantos populares em escalas como meio do caminho para as canções do espetáculo. Um segundo estágio dos encontros seria a averiguação da exequibilidade cênica dos textos processados por Carvalho, se mereceriam cortes ou enxertos e assim por diante. Muito embora ainda houvesse espaço para que o elenco apresentasse uma ou outra cena que pudesse contribuir com o roteiro. Da leitura de Greve na fábrica, extraí um trecho em que os operários se limpavam e, antes de deixarem a fábrica, arrumavam-se, sendo que alguns impecavelmente. Pensei em um quadro no qual os nossos trabalhadores passariam de estarem se lavando para uma brincadeira de se molharem mutuamente, tirando suas roupas como meninos se divertindo com a água. Essa ação foi aproveitada na cena do tanque (que comentamos na $19^{\mathrm{a}}$ tarde de ensaios), resumindo duas ideias em uma.

Prosseguindo com as partes do enredo, naquela terça-feira estudamos os quadros de número quinze a dezenove, abordando o controverso discurso de Lula na assembleia no Estádio na Vila Euclides, em que foi proposta aos metalúrgicos uma trégua à greve em curso. Na obra, meu Arantes diria:

“Amanhã voltaremos para a Volks de cabeça baixa, veremos os sorrisos dos contramestres, a linha acelerada para compensar os dias parados, as chamadas nos cantos para as ameaças. Demissões no varejo. Vinte e sete de março de 1979, o dia em que rezamos o pai-nosso" (CARVALHO, 2016, p. 33 do roteiro).

Essa fala fechava a sequência em que meu personagem percebia a condução dos dirigentes sindicais em propor uma suspensão à paralisação de 60 mil trabalhadores. Como antes, ouvindo os argumentos de Lula, meu veterano manisfestava indignação pela interrupção da greve, eu emendava o seu texto final (descrito acima) na mesma forma: aberta e para todos ouvirem. Sérgio me recomendou que o fizesse internamente e eu abaixei o tom, o que requeria idealizar ainda mais aquelas imagens - “[...] sorrisos dos contramestres [...]" e 
"[...] as chamadas nos cantos para as ameaças [...]" - com uma despreocupação do volume de voz ou a busca de interlocutores, coisas normalmente importantes, mas não naquele caso. É como se eu tivesse que descer três degraus em uma escada representacional: abrir mão da dimensão pública, desfazendo-me de ter que chegar em outrem, como se falasse para mim mesmo, pensando em como seriam os acontecimentos na volta ao trabalho na fábrica. Foi um percurso de fora para dentro que, com a peça em cartaz, precisou ser dosado para que não ficasse exclusivamente intimista e houvesse comunicação com os espectadores.

\section{$33^{\mathrm{a}}$ tarde de ensaios}

Thiago França aqueceu as nossas vozes, jogamos com danças e músicas populares, retomamos as canções da futura peça e fomos ensaiar as cenas dezessete (que continha cinco subdivisões), dezoito, dezenove e vinte. Uma passagem difícil da dezessete era o ataque nervoso pelo qual passava Beto Matos na pele de feitor. Diferentemente do personagem Lucílio - o Fúria Santa conduzido por Bandeira, de quem apenas sabíamos que havia sofrido um colapso -, o de feitor consumava o ato na nossa presença. Após algumas tentativas, Matos foi dosando a descarga de energia para que sua síncope fosse gradativa e evitou (como às vezes acontece com os atores nesses rompantes) estar muito alterado desde o início do ataque. A ponto de fazer com que a cena migrasse de desacertos verbais do feitor para a fisicalização mesma em um surto com ele tremendo ao chão. Disso tudo restou apenas, na peça, um alheamento do feitor, que depois foi rebaixado a operário. Porém, sem dúvida, os laboratórios de seu desconcerto bem serviram à posterior alienação.

E como vínhamos experimentando o uso de um palco giratório no espaço cênico (proposto pelo cenógrafo e figurinista Cassio Brasil), a junção desse mecanismo cenográfico com partes de automóveis que já estavam sendo utilizadas em algumas cenas, produziu o que pareceu ser uma linha de montagem de uma fábrica, objetivo que vinha sendo perseguido desde que iniciamos o processo. Parte do elenco rodava manualmente o palco e os demais iam passando as peças (portas e para-lamas), enquanto um ou outro momento da peça acontecia em giros. E sobre as correções da direção acerca das atuações, escrevi:

- Que João Filho, quando discursava defendendo o sindicato, poderia evitar a dispersão de energia no corpo ao se movimentar mais do que o necessário. Melhor seria se nessas horas ele plantasse os pés e se dirigisse firmemente à plateia.

- Que procurássemos mudar a ordem das frases em nossos textos, para evitar que fixássemos uma precipitada forma vocal que vinha dispersando o significado do que tínhamos a dizer. 
- Que se houvesse tempos indefinidos nas cenas, que os deixássemos acontecer e não buscássemos tapá-los com palavras. Os impasses eram bem-vindos.

$34^{\mathrm{a}}$ tarde de ensaios

Àquela altura, o treino diário da voz e a consequente execução das músicas nas cenas pré-montadas eram inevitáveis. E foi o que fizemos antes de ensaiarmos as cenas vinte e um e vinte e dois da dramaturgia. Logo após, antes de nos debruçarmos sobre o novo material, resgatamos a cena vinte lida no dia anterior e fui informado de que eu não estava dando as intenções corretas ao receber na casa do personagem Arantes os seus visitantes. Eu vinha, entre uma brecha e outra do ensaio, buscando memorizar os textos daquele trecho e quando fomos à prática, ele ainda estava cru em relação aos movimentos do quadro, visto que me ative mais à retenção das frases e palavras do que ao seu significado. Depois disso, ficou ainda mais patente que estávamos em uma fase de simultaneidades, uma vez que era preciso acelerar todas as frentes do trabalho: a de decorar os textos que vinham sendo definidos, guardar na memória as marcações cênicas em desenvolvimento e produzir as intenções discutidas durante as repetições. Ou seja: o trabalho fora da sala teria que se intensificar ainda mais.

No intervalo para o lanche, Sérgio me disse que Arantes seria uma espécie de consciência de todo o processo da peça, no entanto era preciso preservar suas contradições, para que ele não viesse a ser um moralista ou um falador de regras. E como já tínhamos um perfil traçado para o papel, iríamos conversar ainda mais sobre suas idiossincrasias e alterações, visando preservá-lo como uma voz sensata, embora também portadora de defeitos. Privadamente, Arantes era crítico ao sindicato, no entanto, publicamente reconhecia seus feitos. Contrário à interrupção da greve, mas ciente do valor histórico que eram as assembleias com milhares de trabalhadores. Pacífico e não ingênuo, relutante e lutador.

Dentre os apontamentos dirigidos aos atores naquela tarde, pontuei:

- Que independentemente do tamanho da cena ou do papel, teríamos que criar os subtextos dos personagens dentro das situações. Isso contribuiria para que as cenas ficassem vivas e não estéreis.

- Que seria melhor não irmos ao espaço cênico com tudo planejado no que diz respeito ao comportamento das nossas figuras. As sujeiras e imperfeições haveriam de ter lugar, a fim de evitarmos uma assepsia artificial nas relações entre os papéis.

- Que cuidássemos para evitar a tipificação quando ela surgisse (caso de adultos representando crianças na peça) e que isso não ficassse à frente das motivações reais dos 
personagens, o que poderia fazer com que os espectadores acompanhassem menos a história e mais a performance dos atores.

$35^{\mathrm{a}}$ manhã/tarde

Naquele sábado, concluímos uma segunda etapa dos ensaios. Havíamos trabalhado as vinte e cinco cenas do roteiro nas duas últimas semanas de atividades e conferimos sua viabilidade técnica e artística. Inevitavelmente, conversamos sobre o assunto e reafirmamos as intenções de encontrarmos fissuras no bloco de um contexto político e econômico altamente desfavorável no Brasil, durante o período em que preparávamos $O$ pão e a pedra. Cheguei a comentar que se conseguíssemos um pouco da união e persistência dos nossos personagens, que diante de condições tão adversas como as que enfrentaram em suas funções nas fábricas, encontraram tempo e disposição para se organizarem em greves, solidarizarando-se com suas comunidades, a nossa peça faria sentido como o movimento operário o fez durante os anos de 1978, 1979 e 1980.

\subsection{RUMO À ESTREIA: A UNIÃO ENTRE A DRAMATURGIA, A ENCENAÇÃO E A ATUAÇÃO}

$36^{\mathrm{a}}$ tarde de ensaios

Começamos a reensaiar as primeiras cenas da peça, agora com o objetivo de estabelecer a sua organização com vistas à estreia. Trabalharíamos em duas direções: a primeira realista, tendo como primazia no processo a conexão entre os personagens; e a segunda deveria trazer a clareza dos enunciados (narrativas), tanto para quem os emitisse quanto para quem os receberia. A resultante dessas duas premissas seria a procura da vivacidade cênica, propósito maior da relação entre os atores. Conquanto, Sérgio de Carvalho, ciente dos riscos dos intérpretes se ensimesmarem em função dessa fase de memorização, frisou-nos que priorizássemos a compreensão dos acontecimentos das cenas.

Diante disso, reparei:

- Que a direção pediu a João Filho, em seu primeiro discurso como aspirante a sindicalista, para que ele definisse seus ouvintes, evitando assim que suas palavras dispersassem.

- Que na cena em que o feitor nos trazia os novos macacões de trabalho (com golas vermelhas que iriam identificar quem saísse do setor, como medida de segurança), Beto Matos procurasse retirar dos objetos (os macacões) os seus textos e não o contrário. "Da relação com as coisas é que surgem as palavras", disse-nos Sérgio. 
- Que nós, os atores, havíamos estudado as nossas falas, mas que não nos havíamos atentado para as relações entre os personagens.

$37^{\mathrm{a}}$ tarde de ensaios

A cada encontro, recuávamos ao último quadro ensaiado no dia anterior e entrávamos nos que estavam por vir, avançando o mais possível. E naquela quarta-feira foi a vez de repassarmos as cenas de três a seis, sobre as quais registrei:

- Que deveríamos estudar as mudanças de interesses dos personagens em relação aos outros papéis. Descobrir quando isso acontecia e por quê.

- Que, mais que os textos, tínhamos que ter em mente a sequência das ações das nossas figuras e perceber o vínculo entre os parceiros em cena.

$38^{\mathrm{a}}$ tarde de ensaios

Rogério Bandeira propôs exibir no centro do palco giratório uma roda gigante de brinquedo (em miniatura), sendo que ele (no papel de Lucílio - Fúria Santa) e Helena Albergaria (Joana Paixão), na lateral do palco, estariam como que em um dos gomos da roda, apreciando a vista lá de cima. A junção do giro do brinquedo com as movimentações corporais dos atores reproduzindo o mecanismo de uma roda-gigante, encaixada numa situação apropriada ao enredo, produziu um evento propício para a peça e por isso a ela foi incorporado, transformando-se em um dos momentos mais emocionantes do espetáculo.

Entre as minhas notas escritas durante aquele ensaio, estavam:

- Que percebi um indício de estar agindo como personagem, no trânsito entre decorar os textos e raciocinar do ponto de vista do papel. Foi quando eu agi sem palavras, procurando tapar com o corpo o campo de visão do feitor quando este vinha averiguar o que estava acontecendo na nossa seção. João Filho (como o personagem Jaílton) distribuía panfletos sobre a greve escondidos dentro de uma revista de mulheres nuas e eu evitava que isso fosse visto pelo chefete. Uma ação que não fazia muita diferença na cena, mas para mim foi importante perceber que começara a atuar pelo raciocínio de Arantes, me descolando de apenas dar as falas que estavam sendo decoradas.

- Que eu iniciei a cena da grande assembleia no Estádio da Vila Euclides sem levar em conta os antecedentes do meu personagem, que vinha discordando da postura dos sindicalistas. Fiz um operário já empolgado, esquecendo a sua ambivalência de quem tem distância do sindicato e, no entanto, está favorável à greve. Sem percorrer as etapas, foi como se eu me adiantasse para o final da cena, quando lá, sim, estaria envolvido com a movimentação a 
ponto de dançar no gramado do estádio. Ou seja, caí no erro de eleger um estado genérico para o papel, o do embevecido, o que passava por cima do gradiente pelo qual eu deveria percorrer - desconfiado, aderindo e finalmente empolgado pela força de tamanha agitação coletiva.

- Que creio ter sido sincero ao dizer ao jovem Jaílton que tinha sido como ele - a respeito de me envolver com mobilizações grevistas. Não posso afirmar que isso aconteceu porque trabalhei mais do que os meus outros textos ou se foi uma inspiração momentânea. Pode acontecer que nessas primeiras vezes em ensaios que emitimos textos mais longos, fiquemos um tanto nervosos, porque os memorizamos à parte e não sabemos se, ao os falarmos dentro da cena andando, daremos ou não vida a eles. Talvez por estar estudando continuamente os trechos que seriam ensaiados naquela semana, eu seria mais assertivo em uma outra passagem, o que apontava para a necessidade de continuar me empenhando sobre o material dramatúrgico. Dias depois, essa parte foi cortada, por não combinar com o ritmo do restante da cena, no entanto a transitória autonomia do papel aconteceu.

$39^{\mathrm{a}}$ tarde de ensaios

Como estávamos a somente treze dias da estreia, o horário dos ensaios se alongou e abreviamos os aquecimentos. O elenco chegava antes para se preparar e o espaço ficava cada vez mais cheio de partes e objetos do cenário. As músicas eram cantadas uma vez ao piano e a outra já no espaço cênico. A direção chegara ao corpo a corpo com os atores, pois tínhamos que nos afinar na perspectiva de uma primeira versão da peça. Entre as poucas notas que consegui tomar durante aquela tarde, estavam:

- Que a nossa dramaturgia era elíptica, ou seja, entrecortada temporalmente ao interrompermos uma ação que voltaria mais à frente. Ao retomarmos, teríamos que não recomeçá-la, mas continuar com a mesma ou uma energia ainda maior em relação ao ponto em que ela parara. Isso porque aconteceu de, na cena do bar (a de número dez), haver um jogo cênico entre o grupo das mulheres e o dos homens, no qual, enquanto um agia, o outro ficava estático, e foi detectado pela direção que aquele que ficava parado, ao voltar, reduzia sua mobilização, fazendo com que a cena esmorecesse.

- Que Sol Faganello poderia procurar um caminho contrário ao que ela adotara para estar bêbada na festa como a militante integrada à produção. Carvalho voltou a usar o exemplo dialético stanislavskiano para que ela não demonstrasse a malemolência do personagem com a voz pastosa e as pernas bambas, e sim que procurasse ser a mais firme possível, querendo se exibir sóbria. 
- Que na cena treze, na qual se dava o confronto dos grevistas com a polícia, deparamo-nos com a dupla função atoral entre narrar e dramatizar diferentes partes de um mesmo trecho. Para tanto, era preciso clareza e entendimento sobre as narrativas e o maior envolvimento nos fragmentos dramáticos. O que não significava pressa nas ações para voltar ao estado narrativo. Ao contrário: as células dramáticas, quando fosse o caso, sofreriam dilatações, assim como as narrativas que, mesmo apreensivas por tratarem da tensão entre a tropa de choque e os trabalhadores, não seriam necessariamente velozes.

- Que na cena quatorze, sobre uma assembleia improvisada que decidiria os rumos do movimento grevista diante da cassação da diretoria do sindicato, eu tipifiquei meu Arantes. Sérgio chegou a me dizer: "Ney, eu já te vi coordenando as assembleias da Cooperativa (ver nota 78) e a sua postura não era essa". Concordei imediatamente e o refiz sem espremê-lo naqueles dispensáveis desenhos de corpo e voz para o meu velho operário. Reassumi um porte de quem quer dominar o nervosismo parecendo calmo e que realmente faz uma proposta política diante de um conjunto de trabalhadores. Migrei de uma força por meio de uma voz gritada e de uma tensão muscular para uma emissão vocal apropriada à situação e a convicção de quem persuade com equilíbrio, por acreditar no que diz. Firmeza não necessariamente é volume vocal ou crispação física, mas, por vezes, o seu contrário. Com isso, meu desempenho mudou, o que não me eximiu de pensar nessa atávica tendência ao óbvio: potência igual a arroubo, determinação igual a valentia. Se eu fosse só assim, seria o antidialético.

$40^{\mathrm{a}}$ tarde/noite

Mais e mais o processo se afunilava, tendo em vista que estávamos a doze dias da estreia. Em uma jornada de oito horas de trabalho na qual, além das músicas, ensaiamos neste dia seis cenas (da quinze a vinte e um), e rumávamos ao fechamento de mais uma etapa do projeto. Eu vinha memorizando os textos e as ações do que estava em preparo e, por ocasião de estar atuando no filme Guarniere ${ }^{123}$, foi preciso reler a peça $A$ semente, o que rebateu em algumas particularidades do meu personagem em $O$ pão e a pedra. Essa outra obra do autor de Eles não usam black-tie aborda os engajados na luta operária por volta de 1960, o que me forneceu um passado para o meu papel, assim como endossou o histórico do proletariado brasileiro:

Ato I - cena V

${ }^{123}$ Documentário de Francisco Guarniere, neto do dramaturgo e ator Gianfrancesco Guarniere. 
Reunião do Partido. Mesa, quatro cadeiras. Reúnem-se: Agileu, Cipriano, Jofre e o assistente do Comitê Regional.

$[\ldots]$

JOFRE: Bem, companheiros. Eu, antes de qualquer coisa, quero fazê umas crítica. Principalmente ao companheiro Agileu. O companheiro anda muito autossuficiente. O companheiro pensa que o que ele fala é sempre certo... Passa semanas sem reuní, só discutindo com a gente nos encontros rápidos. Isso vem prejudicá as tarefa. É por isso que saiu o jornalzinho convocando o pessoal pra greve, sem ter condições de greve. Bem que o camarada assistente tinha falado, num tinha as condição... Mas é o tal negócio, o companheiro quer fazer a revolução sozinho! Tá aí. Pagou seu erro, está na ilegalidade. Prejudicando o Partido. O pessoal, na fábrica, atemorizado - com medo de tudo. Foi isso que nós lucramos, companheiros.

AGILEU: Acabou?

JOFRE: É só sim...

AGILEU: Cipriano.

CIPRIANO: Eu tô de acordo com o Jofre.

AGILEU: Companheiros, eu quero...

ASSISTENTE: Um momento, parece que chegou a hora da direção se manifestar...

As críticas feitas pelo Jofre são justas. A direção tem o dever de advertir o companheiro. Convocar uma greve, quando não há nenhuma condição, é um mal. É erro. É até sabotagem, traição... (GUARNIERI, 1978, p. 54-55).

Entrar, pelas lentes de Guarnieri, em uma discussão fechada do Partido Comunista por volta da década de 1960, bem situava a postura dos seus membros e os obstáculos que enfrentavam. Similaridades que, sem dúvida, rebateriam no meu papel.

$41^{\mathrm{a}}$ tarde de ensaios

Thiago França exercitou nossas vozes e Lincoln Antonio nos dirigiu para que cantássemos as músicas da peça, como vínhamos fazendo todos os dias. Na medida em que a estreia se aproximava, tínhamos que estar cada vez mais preparados e afinados rítmica e melodicamente. Na sequência, trabalhamos as últimas cenas que ainda restavam daquela segunda leva de visitação ao texto, o que apontava para um primeiro ensaio geral que seria realizado no dia seguinte. Antes, consegui registrar:

- Que Thiago poderia fazer um militante estudantil ao mesmo tempo educado e grosseiro, uma vez que apenas um malcomportado ficaria unilateral. Na cena em que esse personagem cobrava, sectariamente, uma oposição inequívoca do meu Arantes sobre o sindicato, verificamos que quanto mais delicado ele fosse em suas atitudes e no cuidado em falar, mais estranhos e engraçados ficariam seus posicionamentos inflexíveis. 
- Que tive outra demonstração da eficácia pela dispensa dos textos impressos em folhas de papel para poder memorizá-los. No meio do ensaio, Sérgio me passou uma narrativa de abertura da cena vinte e quatro. De ouvido, não peguei exatamente palavra por palavra do trecho, mas o seu siginificado e o emiti sem maiores dificuldades. Como descrevi no Capítulo 2 (p. 141-142), a projeção das imagens do texto e o seu sentido vieram-me mais imediatamente do que se eu tivesse que parar para estudá-las na forma impressa.

- Que Sérgio corrigiu uma minha precipitação: no afã de despejar os textos decorados (fase em que pouco nos ouviríamos, como a direção já havia previsto dias antes), descarreguei a frase: "Não consegue dizer?" - sobre as negociações entre sindicato e a Fiesp ${ }^{124}$, e sequer esperei para constatar que Jaílton (papel de João Filho) ficara em silêncio por alguns segundos, o que faria com que eu percebesse que ele estava sem ter o que dizer sobre a reunião com os patrões. Somente quando Sérgio me chamou a atenção é que me dei conta da minha pressa como ator em soltar as palavras, sem reagir de fato ao meu colega silenciar por não saber o que falar.

- Que o diretor, uma vez mais, apontou-nos que os nossos textos sem ações físicas eram dispensáveis. Que as frases textuais eram consequência de como agíamos e não o que fazíamos era fruto do que falávamos.

$42^{\mathrm{a}}$ tarde de ensaios

À parte do que vínhamos trabalhando todos os dias, um aspecto que estava na pauta da nossa atuação era o que Carvalho denominava de acúmulo. Significava aguardar ouvindo, entendendo o que era emitido por outro parceiro em cena, antes de responder. Ou pensarmos, observarmos, ater-nos ao que estivesse à nossa volta, instantes antes de agirmos, quando fôssemos os que tomassem iniciativa. $E$ isso para evitar a precipitação, a ansiedade e o irrefletido. Também foi-nos lembrado que cuidássemos igualmente das situações secundárias e terciárias, no sentido de que não deveríamos nos preocupar apenas com o que considerávamos o mais importante ao atuar: os textos longos, os momentos mais intensos ou as fortes emoções. $\mathrm{O}$ desprezo pelas instâncias não centrais dos papéis poderia corroer aquilo que víamos como principal, comprometendo todo um personagem e a própria obra.

$43^{\mathrm{a}}$ tarde de ensaios

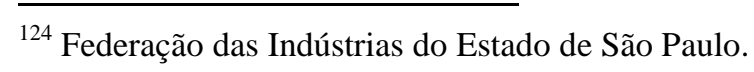


Conversávamos, Beto Matos e eu, sobre as dificuldades daquele momento crítico. Para que a direção tivesse uma boa visão se a dramaturgia em edificação tinha ou não eficáfia, era preciso que o elenco atuasse razoavelmente, sem o que não se poderia saber ao certo se os problemas advinham da escrita ou da interpretação das cenas. Por outro lado, o elenco ainda não possuía intimidade suficiente com o material textual, já que, por mais que trabalhássemos em casa, só estaríamos fluentes fazendo e refazendo diversas vezes os episódios da peça ao lado dos parceiros, a fim de nos acostumarmos com questões técnicas (entradas e saídas de cena, movimentações de bastidores etc.) e nos familiarizarmos com os papéis. Todavia, diante do curto prazo para o início das apresentações da obra, havia a necessidade de que os atores reforçassem seus estudos para que os ensaios não truncassem, na expectativa de que os esperados encaixes se dessem o mais rápido possível e assim tivéssemos alguma desenvoltura em nossas ações cênicas. Diante disso, em um encontro que tivemos um dia depois do nosso primeiro e precário ensaio geral, enquanto Carvalho nos transmitia suas anotações, escrevi:

- Que pela exclusiva preocupação dos atores em dizerem suas falas apressadamente, além da falta de escuta entre os companheiros, tínhamos passado por cima de momentos importantes, como a amplificação resultante de atitudes extraordinárias de alguns papéis. Como já dissemos, na cena em que fazíamos um piquete, Lucílio (Fúria Santa) ajoelhava-se dizendo frases bíblicas e apelando para que um trabalhador não furasse a greve. Essa atitude não era comum e repercutiria em quem estivesse por perto. Não se fica indiferente a alguém se ajoelhando desesperado diante de outrem. No entanto, eu mal deixei que tal ação se propagasse minimamente em mim, pois precisava dizer a minha fala seguinte como quem cumpre uma tabela e não atuando com o olhar de quem estava lá naquele instante se espantando ao testemunhar o apelo do meu parceiro.

- Que outra séria consequência desse fechamento dos intérpretes em suas demandas mais individuais do que coletivas foi a perda do sentido das cenas. Ao nos restringirmos às nossas dúvidas, como "qual é a minha deixa?", "o que eu digo agora?" e "será que é a minha vez de falar?”, não atentávamos para o porquê de cada parte da peça existir. O meu diagnóstico foi o de que a minha dedicação ao trabalho fora da sala de ensaios fora insuficiente para evitar este e outros erros cometidos naqueles dias decisivos.

$44^{\mathrm{a}}$ tarde de ensaios

Subia o nível de exigências para toda a equipe, incluindo, naturalmente o elenco. Desde que fizemos um frágil ensaio geral, Sérgio de Carvalho continuava a operar sobre a dramaturgia, seja porque o espetáculo ficara longo (com mais de três horas), seja porque era 
preciso provocar mudanças nas cenas da obra. Com isso, eu tinha que estudar em casa o todo e as modificações dos últimos encontros; chegar mais cedo ao teatro (já estávamos no TUSP Teatro de Universidade de São Paulo, onde iríamos nos apresentar) para repassar em ação os trechos que estavam frouxos, ensaiando sozinho as partes e a peça completa para firmá-las. Sem deixar de me envolver em proposições paralelas que ampliassem o espectro do meu personagem. Isso se traduzia em fazer desenhos da fábrica e da casa do meu personagem e inventar pedaços de sua biografia, segundo o exemplo:

\author{
Nome: Arantes Pereira \\ Data de nascimento: 25/09/1929 \\ Local de nascimento: São Paulo/SP \\ Como chegou em São Bernardo do Campo: Mudou-se para escapar da perseguição \\ política $^{125}$ \\ Escolaridade: Científico incompleto \\ Estado civil: Solteiro \\ Profissão: Metalúrgico (conserta as peças com defeitos antes que elas entrem na linha de \\ montagem)
}

Ficcionalmente, Arantes casou-se duas vezes, mas não teve filhos. No tempo da peça, ele vivia sozinho e cuidava de todas as tarefas da casa. Vivia entre o desejo de batalhar politicamente pelas causas dos metalúgicos e preservar o seu emprego a fim de se aposentar em cinco anos.

$45^{\mathrm{a}}$ manhã/tarde de ensaios

No sábado que antecedeu a quinta-feira seguinte da estreia, ensaiamos algumas cenas para depois fazermos a peça toda, mesmo conscientes de que havia lacunas, como transições entre partes pouco ensaiadas. Mesmo evoluindo em relação ao primeiro ensaio geral, a falta de relação entre os atores e os seus personagens grassava. Ainda não dominávamos a sequência do roteiro - "O que vem agora?", era sussurrado entre uma cena e outra. De modo que ficava difícil nos abrirmos aos colegas. A direção voltou a requisitar que priorizássemos o fazer chegar no outro nossas intenções e que ouvíssemos de fato o que nos vinha de fora, saindo do invólucro em que estávamos mal parados. Mesmo assim, o ensaio sem interrupções foi melhor que o anterior, sobretudo nas cenas dos embates políticos coletivos. No entanto,

\footnotetext{
${ }^{125}$ Ideia retirada de um depoimento dado a nós por Augusto Portugal, estudante que se tornou operário no período tratado pela nossa peça.
} 
tivemos novamente muitos problemas técnicos e artísticos, o que nos levou a reparar os erros cometidos, a fim de, gradativamente, aprimorarmo-nos.

Nos intervalos dos estudos e ensaios, eu minimamente procurava alargar a círculo do meu papel: em sua primeira cena, Arantes chegava ao vestiário da fábrica. Como seu período era noturno, das seis à meia-noite, eu supunha que antes ele tinha lanchado em casa (com um pão feito por ele mesmo) e caminhado até o trabalho, pois vivia perto dali. Entre o portão e o vestiário, encontrava-se com Jaílton (João Filho), com quem discutiria os preparativos da greve:

JAÍLTON: A greve vem aí Arantes. Olha isso aqui. (Passa-lhe um panfleto.)

ARANTES: Vai ser como no ano passado?

JAÍLTON: O que é que tem o ano passado?

ARANTES: O sindicato a reboque de meia dúzia da categoria?

JAÍLTON: Arantes, as coisas mudaram, a gente amadureceu. Deixa de ser teimoso.

ARANTES: Olha, eu só saio do meu canto se for pra valer. Agora, se for para fazer firula e na hora do pega pra capar dar pra trás, estou fora.

JAÍLTON: Tem que vir com a gente pra ver, velho. Não ficar aí isolado, pois você é importante pra causa.

ARANTES: Você diz isso porque está empolgado. É a idade. Logo passa.

Naturalmente que a literatura dos meus exercícios escritos não era das melhores. Porém aquilo me servia de gatilho quando, na cena mesma da peça, Jaílton me provocasse: "Você gosta de criticar, hein?" (CARVALHO, 2016, p. 6). Um dispositivo elementar já relatado outras vezes neste trabalho. Um expediente mutável de acordo com a imaginação de cada intérprete que, a exemplo de outras peças do Latão, estendi a todos os momentos anteriores às cenas do meu veterano operário. Trago à tona algumas partes desse procedimento.

Uma terceira participação de Arantes na trama acontecia na grande assembleia realizada no Estádio da Vila Euclides. Projetei que meu personagem se prepararia para esse encontro vestindo uma roupa que não seria uma de suas melhores, para não transparecer que estava empolgado em participar de uma reunião política daquela dimensão. No entanto, um perfume, que só usava raramente, ele passaria em seu corpo.

Decretada a greve, teríamos que fazer piquetes. E, com isso, a rotina de Arantes seria quebrada com as saídas durante o dia para as mobilizações programadas pelo sindicato. Antes 
de se posicionarem para barrar quem quisesse furar a greve (cena da peça), ele ouviria de Jaílton as recomendações (fora da cena: momentos pensados por mim):

JAÍLTON: Pessoal, sempre de braços cruzados. Não aceitar provocações de jeito nenhum. Quem vem trabalhar sabendo da paralisação vai encrencar e nós temos que ser os mais educados, explicando as reinvidicações que serão um ganho para todos. Paciência e determinação. Quem não tiver jeito, vamos deixar passar, porque, depois da assembleia de ontem, estamos muito bem calçados.

Na passagem mais dura da peça, em que a repressão demonstrava sua força sobre os grevistas, concebi que antes meu personagem escutara pelo rádio que o Sindicato dos Metalúrgicos fora interditado. Ele, que não concordava com muitas das posições de seus dirigentes, refletia que entre o governo militar e os seus correligionários, teria que ficar ao lado destes últimos, sem dúvida. Uma chamada telefônica de um colega da fábrica o convocava para que ele fosse ao sindicato e assim ele iria com o seu Corcel, pela pressa da situação. Chegando lá, se deparava com muita gente e se juntava à multidão que procurava um lugar para fazer uma assembleia.

Tais suposições, tangenciais à dramaturgia da obra, complementavam a linha do meu papel, mesmo sem a comprovação de que tal ideia fosse eficiente na constituição de um personagem. Todavia, era um recurso que fazia de Arantes alguém mais conhecido por mim.

$46^{\mathrm{a}}$ tarde/noite de ensaios

Entre o pessoal da cenografia, figurinos e iluminação que realizavam suas funções, ensaiávamos algumas cenas antes de repassarmos o todo da obra. Foi quando Sérgio nos lançou um termo curioso sobre um nosso problema de interpretação: síndrome de dignidade. Que nada mais era do que dar demasiada importância às falas dos nossos textos, como se cada uma tivesse a aparência do último texto da peça. Rimos da observação da direção porque nos identificamos com ela. Quem é ator talvez saiba que não é raro ficarmos esperando pelo nosso momento de falar e então queremos dar destaque a esses instantes. De maneira que as falas podem sair encorpadas demais, criando uma atmosfera que nem sempre tem relação com o sentido e com o objetivo das frases nas situações do enredo. Assim, quase estreando, a representação dos atores no grupo estaria entre um realismo posicionado e a suspensão daquilo que era demasiadamente sublinhado. 
Para diminuir a tensão de ensaiar, estudar, memorizar, cantar e aprender a movimentar os objetos de cena, eu procurava respirar, alongar-me e me automassagear. Pensei comigo que em vez de ficar exigindo de mim mesmo não parar o tempo todo de praticar os textos e o trânsito no palco, melhor seria se eu estivesse mais relaxado, com o corpo e a voz aquecidos, confiando em que assim a memória e a intuição ganhariam mais espaço em mim. Diga-se que eu vinha praticando ioga e frequentando uma academia como reforço à minha preparação corporal.

Sobretudo, vínhamos melhorando ensaio após ensaio, mas ainda com cenas precárias que reclamavam mais empenho sobre elas. Foi o que fizemos no dia seguinte.

\section{$47^{\mathrm{a}}$ manhã/tarde/noite de ensaios}

$\mathrm{Na}$ terça-feira (quinta seria a estreia), como precisávamos trabalhar as cenas que careciam de acertos na montagem, começamos pela manhã. Foi aí que aconteceu uma inversão no que eu vinha fazendo, que considero modelar, em termos dialéticos. Na já comentada cena do tanque, Arantes lavava roupa ouvindo "Sentado à beira do caminho", de Roberto Carlos, ao rádio, tendo Fúria Santa como companhia. Suas palavras, cuja inspiração para o nosso dramaturgo foi Lênin, eram:

\footnotetext{
ARANTES: Quando eu ouço uma música como essa, eu penso, que maravilha, eu gostaria de ter tempo para escutar isso todos os dias - talvez seja ingênuo da minha parte - eu penso, quantas coisas maravilhosas, sobre-humanas, os seres humanos podem fazer. Me dá vontade de dizer pequenas coisas estúpidas e bonitas e acariciar a cabeça das pessoas capazes de criar tanta beleza no meio desse inferno, desse mundo injusto (tira a própria camisa e começa a lavar). Mas não é o momento para acariciar a cabeça de ninguém, você poderia ter sua mão mordida, decepada, nós temos que bater na cabeça deles sem nenhuma misericórdia, mesmo que nosso ideal seja não usar a força contra ninguém, porque nossa tarefa é muito difícil, às vezes infernal (CARVALHO, 2016, p. 39 do roteiro).
}

Quando, por volta das dez da manhã, eu comecei a pronunciá-las ensaiando, primeiro Sérgio percebeu que havia em mim um registro romântico na primeira parte do texto, o que combinava com o seu teor. E aí estava o nó: meu diretor reverteu a ótica que eu havia adotado me dizendo que Arantes transparecia antes descontentamento do que satisfação, por ele ser, na sua condição de operário, privado do prazer de ouvir música e de lavar roupa no quintal brincando com os amigos. Assim, haveria uma certa indignação quando o veterano expressava seu maravilhamento com aquilo que poderia acontecer e que a ele não era permitido. A meu ver, Carvalho jogava com uma visão dialética em relação à minha 
interpretação: meu personagem se desencantava, pois sabia que o encantamento era possível, porém lhe fora furtado. Inconformava-se por ter consciência de que a vida poderia ser diferente e melhor, mas sua realidade era mais seca. Esse tropo transformaria a concordância entre texto poético e atuação encantada em uma assimetria entre palavras aparentamente dóceis em atrito com uma representação de alguém contrariado.

$48^{\mathrm{a}}$ tarde/noite de ensaios

A um dia da estreia, terminamos o ensaio para a iluminação, enquanto Sérgio de Carvalho nos reaprumava em cenas nas quais estávamos inseguros e em outras que solicitavam mais trabalho sobre os atores. Guardei daquela tarde/noite que aspiraríamos a uma não coincidência entre fala e gesto: o que se diria nem sempre seria acompanhado por gestos correspondentes, para evitarmos apenas ilustração das frases.

$49^{\mathrm{a}}$ tarde de ensaios/noite de estreia

$\mathrm{Na}$ tarde do dia de estreia, fizemos um ensaio geral não sem problemas técnicos (erros de contrarregragem do próprio elenco) e artísticos (esquecimentos de falas e de marcações cênicas, além de não executarmos bem as músicas). Como já vinha fazendo, Sérgio promoveu novos cortes na peça, a fim de cortar gorduras do espetáculo. Não obstante, sua principal recomendação seguia sendo a de que nos relacionássemos uns com os outros, minimizando automatismos como esperar o parceiro dar seu texto para que eu desse o meu. Esse descompasso retirava a escuta alheia e prejudicava o envolvimento dos papéis com as cenas. Como a ideia era agir e reagir pensando no que os personagens tinham a dizer uns para os outros, somente a atenção dos pares entre si garantiria alguma organicidade sem a qual os diálogos ficariam ocos. O nosso diretor e dramaturgo disse ainda que teríamos que levar em conta a hierarquia entre os papéis como, por exemplo, o respeito que se deveria ter, em algumas cenas, ao meu personagem - o velho Arantes. Cuidados que passaríamos a trabalhar nos dias seguintes à estreia, que seria dali a meia hora.

\subsection{PROBLEMAS SOBRE AS ATUAÇÕES}

Entre nós, estrear é apenas uma das fases do trabalho. Com hiatos, que seriam paulatinamente preenchidos a cada apresentação por vir, tivemos um começo razoável. O que siginificava que dali para a frente poderíamos penetrar nas minúcias das interpretações. 
A estreia

Para a nossa surpresa, a primeira apresentação para o público correu bem. As incertezas sobre o espetáculo permaneciam, porém, todo o trabalho de cerca de dois meses havia dado resultado. Em vista das dificuldades pelas quais passamos durante o ensaio geral vespertino, a primeira noite foi melhor do que esperávamos. Um ou outro dispositivo não funcionou no instante esperado, mas os atores e músicos contornaram os acidentes e tivemos um final satisfatório mediante um processo tão intenso e abreviado.

$2^{\mathrm{a}}$ noite de apresentações

Depois de ensaiarmos algumas nuances não suficientemente articuladas do trabalho, abrimos as portas para receber os espectadores na segunda noite. Lembrando do que Sérgio vinha nos pedindo, busquei prestar mais atenção ao que meus colegas me diziam em cena e também a olhar nos olhos deles, o que para mim melhorava a qualidade da contracenação, uma vez que os olhares se imantam proporcionando a concentração. Outro recurso que comecei a recuperar, justamente por estar mais familiarizado com o todo da peça, foi o de pensar nos bastidores, entre uma cena ou outra, no que o personagem estaria fazendo antes de começar a agir - e, sem dúvida, as anotações que eu vinha fazendo sobre isso me ajudaram. Por exemplo, quando Arantes estaria lavando roupa e ouvindo Roberto Carlos na cena dezenove, pronto na coxia para colocar o tanque cenográfico no espaço cênico, pus-me a pensar na minha vida na fábrica e que eu me acostumara a ponto de depender daquela rotina, com receio de ficar perdido se me desligassem do emprego. Assim engendrava uma contradição: lutava contra aquelas precárias condições de trabalho, no entanto talvez não soubesse me virar sem elas. Pensamentos que me potencializavam para chegar ao palco.

$3^{\mathrm{a}}$ noite de apresentações

No sábado, ao chegarmos ao teatro fomos convocados a ensaiar a cena em que o sindicato é interditado e o motivo pelo qual a direção queria retrabalhá-la era a falta de contato entre nós. Novamente estávamos mais preocupados em nos livrarmos dos nossos textos, sem que eles fossem uma reação ao estávamos ouvindo. Como atores ansiosos, encobríamos os personagens que, como gente real, antes de responder, deveriam pensar no que tinham acabado de ouvir. As falas ficavam quase sobrepostas e foi necessário treinar para que mudássemos o modo como estávamos nos portando. Em uma conversa, Carvalho nos delegou que o impensado desta e de outras cenas só seria quebrado se prestássemos mais atenção e entendêssemos o que estávamos falando uns aos outros. Que, do seu ângulo, a 
atuação possuía a dimensão comunicacional (fazer com que o espetáculo e os seus fatores chegassem aos espectadores através da voz, gestos, músicas etc.) e a ficcional, vivencial, que dependia da interiorização dos papéis nos atores e da capacidade destes em acreditarem em suas metamorfoses em personagens. E que, nesse sentido, tínhamos que interpretar como realmente nos comportamos na realidade, incluindo o tempo da atenção e da recepção ao outro antes de qualquer réplica. Na outra ponta, era igualmente importante que os emissores checassem, depois de se expressarem, se o que haviam dito chegava ou não nos respectivos destinatários. Simplificando, era hora de pararmos de nos preocupar com qual seria a próxima cena ou fala para vivermos os papéis e suas relações. Que, durante o dizer, se não drenássemos as verbalizações com os pensamentos dos personagens, corríamos o risco de atropelar nossas próprias falas, movidos mais pela energia do que dizer do que pelo envolvimento de estarmos comunicando alguma coisa a alguém. Era preciso controlar os ímpetos para que não fôssemos utrapassados por eles e assim borrarmos a clareza do que pretendíamos dizer. E, perspectivamente, à revelia da leitura única das nossas ações, descobriríamos seus subsentidos e o que se contrafizesse ao enunciado central de nossas sentenças. Permitiríamos que alguma sujeira contaminasse nossos atos e começaríamos a projetar imagens nas expressões. Se não fosse possível realizá-los de uma vez, que as escalonássemos em diração a uma atuação matizada.

A peça estava sendo bem recebida, contudo havia muito o que trabalhar. Se a dramaturgia e a direção cuidavam do todo e dos recortes em ensaios que precediam as apresentações, durante as funções éramos nós que tínhamos que aperfeiçoá-las. Da minha parte, além da insegurança natural dos poucos quatro dias de sessões ao público, começara a me perguntar o que fazer para melhorar minha concentração dentro e fora de cena. $O$ exercício de escrever sobre os antecendentes de cada participação de Arantes no enredo vinha me auxiliando, embora não o bastante. Se quando, do ponto de vista do personagem, fugia-me a atenção nos momentos em que ele não estava no miolo das cenas, dentro delas eu tinha como apoio o que havia determinado como prévio às entradas propriamente ditas do meu papel - isto é, quando ficava fora das ações.

$5^{\mathrm{a}}$ noite de apresentações

Folgamos entre segunda e quarta, depois das quatro primeiras exibições. Isso fez com que nos distanciássemos da peça e seria preciso reensaiá-la na quinta-feira à tarde, antes da sua primeira função noturna da segunda semana da temporada. O principal problema entre nós, os atores, continuava sendo a falta de relação, sintomaticamente manifestada, como a 
desistência da ação antes mesmo que ela terminasse. Logo na primeira cena, Sol Faganello (no papel de Luísa, a militante integrada à produção) mostrava um panfleto a Helena Albergaria (a operária Maria da Paixão). Era um material da sua tendência política que ela queria checar se a trabalhadora tinha lido ou não (ver p. 187). O gesto de esticar a mão com o papel deveria ser sustentado, como quem tem interesse em ver se a pessoa que o receberia o pegaria ou comentaria algo sobre o conteúdo do panfleto. Acontece que, como atriz, ela já sabia que o personagem de sua colega não ligaria para aquilo e com isso distensionava o braço, como quem desistia precipitadamente da ação. Esse foi o ponto que o diretor frisou: quando dizemos, perguntamos, mostramos algo a alguém, ficamos na expectativa de uma resposta sem recuarmos previamente.

Da mesma forma, a indissociação entre os bastidores e a cena teimava em não nos deixar: entrávamos em foco com o estado de quem acabara de arrumar os objetos cenográficos nas coxias. Se formos ainda contabilizar que a falta de firmeza nos textos permanecia, piorava o fechar-se cada um em si, sem a devida atenção aos demais.

Mais dois pontos foram lembrados pela direção ao elenco. O cuidado que teríamos que ter com os antigestos, os movimentos contrários aos gestos: as suas oposições. Antes de esticarmos um braço à frente, o levamos para trás, por exemplo. Isso porque quando levantávamos os punhos na cena da grande assembleia da Vila Euclides, os impulsos não poderiam ser imediatos, mas precedidos de alguma resistência, de maneira a serem consquistados e não estarem prontos. E também cometíamos a cristalização precoce das falas: como tínhamos dominado nossos textos, uns de nós já os reproduzíamos pela casca, com um formato pré-desenhado, o que suprimia boa parte dos sentidos das palavras. Pessoalmente, passei o espetáculo daquela noite tentando me concentrar no que viria antes das cenas propriamente e tive dificuldades em me deixar levar pelo imaginário. Ora entrava no universo da obra pelos acontecimentos que circundariam o meu Arantes, ora me dispersava pensando em quem estava na plateia, entre outras derivações. Nesses termos, esforçava-me oscilando entre a concentração e a dispersão.

$6^{\mathrm{a}}$ noite de apresentações

Progredi um pouco no trabalho de visualizar o que procederia as minhas cenas no palco. O exercício não era simples, porque em alguns casos sentávamos nos bancos nas laterais do espaço cênico para assistir os colegas. De modo que, simultaneamente, eu estava atento ao que se passava na peça e o que projetivamente estaria acontecendo com meu papel 
fora de cena. Quem sabe, equivocadamente eu misturava um comportamento atuativo individualizado a uma postura artística coletivista.

$7^{\mathrm{a}}$ e $8^{\mathrm{a}}$ noites de apresentações

Como reforço à sedimentação do meu papel, seguindo um procedimento utilizado em outras peças, escrevi os possíveis monólogos interiores de Arantes. Minha expectativa com isso era a de combater a desconcentração que me limitava. Seleciono apenas dois de todos os subtextos que fiz.

Para quando Arantes vai entrar na fábrica na noite em que a greve seria deflagrada:

Está um ar diferente. O pessoal está andando de cabeça erguida. É a excitação pela greve. Estão todos mais animados. Conheço essa febre. Olha lá, são ônibus para quem está largando agora. Vão para a assembleia. Será que o Jaílton tinha razão? Bem, isso não importa tanto. Se eu tiver que aderir, vou aderir. O melhor é que seja verdade, uma greve de verdade, como as de 68. Aí eu estarei dentro pra valer.

Depois da assembleia improvisada em que Arantes foi aplaudido. Antes da volta de Lula, o velho fala aos companheiros:

\footnotetext{
Obrigado pessoal, obrigado. Mas agora vamos trabalhar. Temos que montar uma comissão para cuidar da intervenção - não podemos deixar a diretoria cassada na mão. Todo apoio ao sindicato. E é preciso pensar na massa que aguarda uma posição das lideranças, mas não vamos deixar a coisa centralizada. Quanto mais gente estiver envolvida em várias frentes, mais o movimento e a greve se fortalecem. E vai ser preciso convocar uma assembleia para reunir todos os trabalhadores e se a gente colocasse alguns deles para falar seria melhor...
}

Mesmo artificiais, tenho a sensação de que esses supostos pensamentos do meu veterano me ajudaram. E como o trabalho de um ator nunca cessa, teria também que cuidar do relaxamento muscular sem esquecer da respiração, uma vez que reparei um ranger de dentes e contrações na região do pescoço e cabeça. Não bastavam a ioga e as práticas físicas que eu vinha fazendo, tampouco os alongamentos que me serviam de aquecimento antes da peça.

$9^{\mathrm{a}}$ noite de apresentações

O teatro estava lotado naquela noite e percebi a utilidade do que vinha fazendo em casa. Como são inúmeros os motivos de dissipação com a peça em andamento, como trocas de roupas e operações de mudanças de cenários, escrever sobre o que aconteceria antes de 
Arantes entrar em cena e redigir os subtextos bem próximos aos meus segmentos na peça, presumo terem concentrado mais do que se eu não escrevesse nada. Também é possível que a falta de foco que eu sentira na semana anterior tenha diminuído com o seguir das apresentações, em que a mecânica da obra vinha ficando, a cada sessão, menos complicada, proporcionando o desfrute das representações do espetáculo.

$10^{\mathrm{a}}, 11^{\mathrm{a}}$ e $12^{\mathrm{a}}$ noites de apresentações

Seguíamos com a temporada que vinha obtendo boa repercussão de público e crítica. Entre nós, continuávamos com o aprimoramento das cenas e das interpretações, sobre as quais tomei algumas notas do que nos dizia a direção:

- Que tínhamos que constituir a lógica das ações internas dos personagens quando eles não estivessem falando em cena. Justamente para que quando interviessem, tivessem assentada uma base que daria sustentação aos momentos mais expostos dos papéis. Isso significaria que cada ator teria que criar sozinho a curva da sua figura cênica entre-falas para evitar dizeres sem substância. Em relação a isso, não me senti defasado, uma vez que já vinha praticando tais indicações.

- Que eu estava sofrendo de "marquismo", uma alusão à tendência de um ator em se marcar em cena. No episódio da assembleia improvisada dentro da reocupação pelos trabalhadores do sindicato interditado pelo governo, eu atuava no meio da plateia. Com o calor das discussões, eu descia em direção e me posicionava no meio do palco, onde teria mais visibilidade. No entanto, se autocentralizar espacialmente vinha menos do personagem do que do ator. Estudamos um meio que expressase o ponto de vista de Arantes, para que o debate ganhasse em coesão.

- Que quando dávamos as falas dos personagens sem que houvesse uma gradação, acabávamos forçando suas emoções, fornecendo-lhes uma intensidade que muitas vezes não existia. Poderíamos chegar às emoções, mas não partimos delas.

- Que um equívoco básico estávamos cometendo: o de só estarmos vivos quando falávamos e murcharmos em cena quando não estávamos com a palavra. Isso transformava as cenas em pedaços que não se uniam, já que um ator não se interessava pelo que os outros estavam fazendo e só se avivava para dizer seus textos.

$5^{\mathrm{a}}$ semana de temporada

Saltando para algumas semanas depois, retomei as anotações com as correções da direção para os atores: 
- Que deveríamos percorrer as dificuldades dos gestos e não procurar pelo mais fácil. Um indicativo atoralmente sutil no sentido de que, na maioria das vezes, pensamos ser melhor nos ajeitarmos às situações teatrais. O que Carvalho estava propondo era o contrário: passarmos pelos problemas físicos dos papéis e não os evitar. Os transtornos com os objetos, com os desencontros dos corpos, por exemplo, seriam positivos porque mais reais do que a limpeza cênica artificial predominante nos acordos entre o elenco.

- Que atentássemos para os átimos nos quais visualizássemos as imagens que precedem a emissão das palavras dos textos quando estivéssemos em ação. Caso contrário iríamos apenas estilingar as palavras.

- Que, ao ouvirmos os parceiros, viéssemos a desenvolver as opiniões internas dos personagens. Porque quando alguém nos fala, desenvolvemos mentalmente um ponto de vista sobre aquilo, ainda que não o expressemos.

- Que eu não preparasse emocionalmente os principais momentos do papel. Ou seja, eu teria que me cuidar para não emocionalizar o que já possuía uma carga sensível por si só. As emoções têm força própria e é desnecessário reiterar o seu teor.

- Que Arantes aludia à marmita do personagem (logo em sua primeira participação na obra) e que eu não tinha elaborado nada a respeito. Desenhei, então, como eu a faria: arroz, feijão, vagem e carne moída. E que seria cuidadoso e cozinharia em casa a melhor comida para levar à fábrica, a ponto de ela ser comentada pelos meus companheiros como "a marmita do Arantes".

- Que no meu texto final da peça, eu teria que encontrar um incorformismo no conformismo do problema.

O pão e a pedra, prosseguindo em suas funções, continuaria com ensaios antes das apresentações e suas consequentes correções ao elenco por parte da direção, com os aquecimentos vocais e repassagens das canções, como fazíamos em nossos projetos anteriores. Eu poderia seguir com os relatos, dada a riqueza das trocas e aprendizados que ocorreram entre nós. Contudo, em algum momento este capítulo teria que se encerrar. Antes, deixo uma síntese crítica sobre o projeto:

"Mas, na vida de um povo, há momentos que condensem um passado, definem o presente e deflagrem o futuro? O pão e a pedra, que a Companhia do Latão encena no TUSP, diz que sim" (CONTI, 2016, p. A7). 


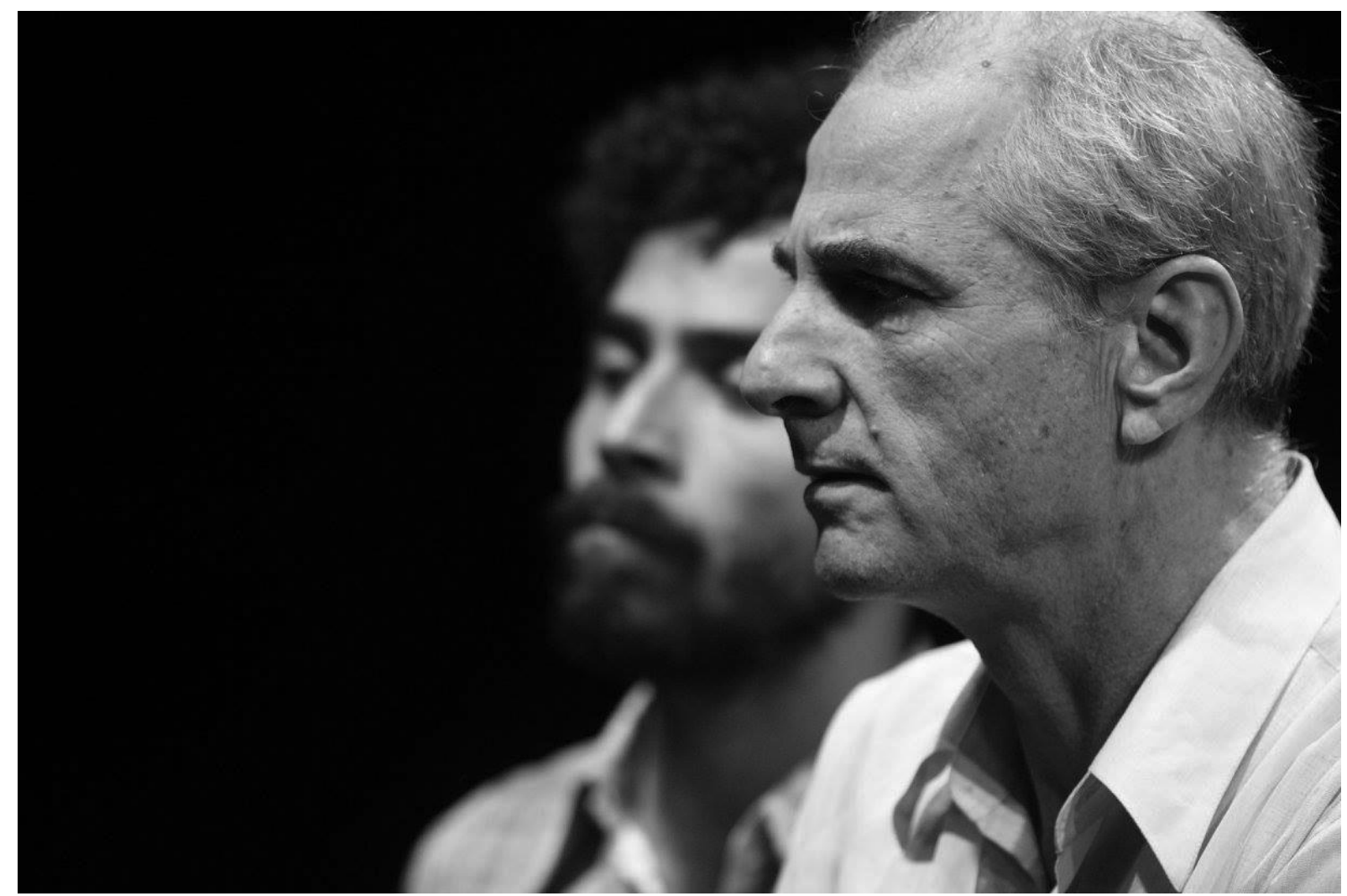

João Filho (Jaílton) e Ney Piacentini (Arantes). O pão e a pedra, 2016. Foto: Sérgio de Carvalho. 


\section{CONSIDERAÇÕES FINAIS}

“O espectador é convidado a tomar posição em torno das contradicões da história e tem o direito de estar de acordo ou em desacordo parcial ou totalmente com o revelado. Estão concientes que seu teatro cria inimigos e adeptos" (ROJAS, 2003, p. 81).

$\mathrm{O}$ crítico da Universidade de Washington referiu-se à presença do Latão no XXV FITEI - Festival Internacional de Teatro de Expressão Ibérica, no Porto, Portugal. Se ele, uma testemunha iniciada, notou a divisão da recepção do público na peça Auto dos bons tratos, os formantes da obra não poderiam agir diferente, atuando nas divergências, primando pela colisão entre duas ou mais atitudes em seus papéis teatrais. No entanto, foi longo o traçado até obtermos ciência dessa faculdade.

Uma das primeiras incumbências dos nossos comediantes foi a de apreender a narrar com objetividade, o que se distinguia dos relatos cênicos dramatizados. Isso significou que partimos para o treino de descrições de acontecimentos de uma forma clara, econômica e isenta de meneios. O que geralmente se traduziu por falar diretamente ao público sem sublinhar sentimentos e evitando excessos gestuais. Na outra borda, esteve a interpretação realista, seguindo os parâmetros dramáticos. E, neste caso, sim, as emoções e os movimentos corporais fariam parte do nosso arcabouço atuativo. Sem embargo, o propósito maior foi a intersecção dos dois modos - o narrado e o vivenciado, que viriam a encorpar a representação latoniana desde o seu início. Naturalmente que as vias não eram estanques, tendo em vista que, na cena, as narrativas se tingiam de impressões, assim como buscávamos o maior entendimento possível ao revivermos subjetividades. Os meios estariam separados e reunidos, contíguos e nuançados. Em síntese, é o que se pode considerar a respeito da interpretação nos nossos dois projetos iniciais: Ensaio sobre o latão (1997) e Santa Joana dos Matadouros (1988) - ambos de filiação brechtiana.

Já $O$ nome do sujeito (1988) foi escrito pelo grupo, primando pela brasilidade. Em relação à atuação, o percurso por nós adotado não foi o da completa desdramatização. Tívemos personagens bem desenhados enquanto a epicização se deu através da fragmentação cênica, pela montagem e desmontagem cenográfica à vista dos espectadores, nas canções que cortavam o fluxo do espetáculo e em narrativas simultaneamente objetivas e envolventes:

Hoje um corpo de negra vai aparecer boiando na praia, o corpo de uma mulher que cometeu suicídio, e vai ficar ali oscilando para diante e para trás, segundo as marés, resvalando na 
areia, dissolvendo as espumas, visível das sacadas da cidade do Recife. Cem pessoas vão passar, deter-se diante do cadáver inchado e seguir muito filosoficamente o seu caminho. É verdade que para elas será o corpo de uma negra, este, que vai aparecer boiando na praia. Ninguém deve se acostumar com o vento açoitando o mar e nem com as ondas beijando a areia (CARVALHO; MARCIANO, 2008, p. 78).

Levando-se em conta que a atriz (Georgette Fadel), intérprete da negra, era a narradora do desaparecimento de seu personagem e que ela dizia esse texto em pé mirando o público, tínhamos uma narrativa sensível e reflexiva. E essa mesma peça também abriu espaço para as relações dialogadas nas quais o realismo circunstanciado se fez valer.

ANTÔNIO: O que estás fazendo meu Deus? Ias cair, ias morrer.

MARGARIDA: Eu ia me banhar no rio. Por que tocam os sinos, você sabe?

ANTÔNIO: É o incêndio. Tem uma hora que está pegando fogo.

MARGARIDA: A Igreja de São Francisco?

ANTÔNIO: O teatro queima, o Santa Izabel está em chamas.

MARGARIDA: E as cômicas, para onde vão?

ANTÔNIO: Ias mesmo te lançar à água?

MARGARIDA: Me leva para ver o fogo? Deve ser bonito.

ANTÔNIO: Levo, como não. Estás te sentindo bem?

MARGARIDA: "Bem”, o que a palavra quer dizer? (CARVALHO; MARCIANO, 2008, p. 80)

Aquele não era um cenário apropriado para uma aproximação entre um imigrante arrivista e uma brejeira deflorada por um barão. No entanto, por uma uma dramática reversa, estabeleceu-se um romance de aparências. De forma que tínhamos, no modo narrativo (objetivo) da morte da negra uma tristeza irremediável; e na junção de Lyra com Margarida (intersubjetiva) um lírico arremedo. Quero dizer que prospectávamos como dialetizar a dramaturgia e a interpretação nas iniciativas da equipe na direção de sua humanização.

Por seu turno, em A comédia do trabalho (2000) as contradições, que antes surgiam mais nas salas de ensaios, deslocaram-se abertamente para a vida nas ruas, cuja precariedade nos mostrou inversões, resumidas no seguinte trecho:

MENDIGA (Aos pedintes.): Ouçam todos. A situação está insustentável. Esses desempregados estão começando a atrapalhar a nossa vida de mendigos. Eles chegam à procura de trabalho, não encontram, ficam deprimidos, começam a beber, aí vêm com seu cobertorzinho... Querem dormir do nosso lado (CARVALHO; MARCIANO, 2008, p. 97).

A realidade nos dizia que a representação das nossas figuras teria que cruzar mais de uma face. 
No passo seguinte, "o que procuramos experimentar desde Auto dos bons tratos foram ativações dialéticas dentro da própria relação realista" (ALBERGARIA, 2009, p. 90). Assim, de 2002 para cá, impulsionados pelos estudos intragrupo sobre interpretação iniciados em $2001^{126}$, fomos à procura das ações contrastantes nos comportamentos dos personagens. Os polos não estariam mais somente entre representar vivencialmente e a sua interrupção por uma narrativa ou canção, mas também naquilo que se entrechocava interiormente nas próprias criaturas propostas.

INEZ: [...] O senhor me beijava as mãos toda vez que eu ia à caixa dos pobres. Cada toalha que pus na igreja, foi pelo senhor. Pensava que fosse agradecido. Beijou-me as mãos quando lhe entreguei o manto de Santa Luzia.

BERNARD: A senhora está bonita.

INEZ: Me perdoa, vigário (CARVALHO; MARCIANO, 2008, p. 171).

O que se via era a mulher do Capitão Tourinho (o mandatário já preso) tentando preservar sua autoridade, mas também reclamando ajuda ao Padre Bernard por não mais ter a proteção do marido. Não obstante, ela resvalava para um apelo afetivo, com uma sensualidade acobertada pela devoção religiosa, o que fazia com que o vigário reagisse canhestramente, embora admirado.

Tal traço, o de unir duas ou mais antípodas em novas justaposições visando uma multifacetação dos personagens, se acentuaria em O mercado do gozo (2003). Nele, tirante a disrupção estruturadora da encenação, havia um categórico atrito entre os papéis e deles consigo mesmos. Foi nessa obra, talvez, que o elenco passou a operar conscienciosamente pela dinâmica dialética no que se refere a fabricar figuras fictícias dotadas de desejos (sublimes) e contravontades (econômicas): “GETÚLIA: Juro que serei sua como jamais fui de ninguém. Quero grudar em você, ser sua abotoadura, sua corrente de pescoço, seu charuto mais precioso" (CARVALHO; MARCIANO, 2008, p. 227).

Uma irrupção dos nossos processos aconteceu em Equívocos colecionados (2004). As entrevistas com Heiner Müller, o piso da encenação, pouco tinham de lineares, fazendo com que a nossa apropriação das palavras do autor de HamletMachine seguisse essa desconexa tendência. E observar as análises feitas por Hans Thies Lehmann sobre o escritor alemão, durante os dias em que conosco ele conviveu, esclareceu a nossa compreensão da dialética mülleriana:

\footnotetext{
${ }^{126}$ Consultar o Capítulo 1, "Parar para estudar", p. 63 a 74.
} 
Mas isso é completamente desinteressante, simplesmente anotar o que acontece, quando falta a consciência para a segunda dimensão, de que fala Goethe, para esse fundo, para essa folha. O curioso é que essa "segunda vida", cuja presença é a realização do lírico para Valéry, parece estar a ponto de desaparecer. Só existem ainda processos superficiais, atrás dos quais nada acontece. Isso é que é o novo: a substância está gasta. Sem substância não existe mais literatura (MÜLLER, 2004, p. 37).

Ao transferirmos as problematizações de Müller para o domínio da atuação, confirmamos a possibilidade de mais de um estrato na representação. Por sua vez, os descompassos nos papéis ganharam outra perspectiva em Visões siamesas (2004). Na medida em que sonhava com a redenção advinda do poder de um Rei, a jovem camponesa Kinara se degradava mais e mais. Sua ilusão a levou a acreditar que ela era o Rei, a ponto de não perceber a morte da mãe. Aspiração individual exacerbada e anulação social como antagonistas. Quanto à interpretação, nessa montagem de ares orientais, acentuou-se o que antes aparecera em Auto dos bons tratos: a revelação das dissonâncias por meio da efusão dos sentimentos dos personagens. Representávamos no limite da perturbação das figuras cênicas, transgredindo-o quando preciso, embora de maneira verossímil.

Talvez a nossa consciência de uma atuação dialética tenha ganhado contornos mais nítidos com O círculo de giz caucasiano (2006), Ópera dos vivos (2011) e O patrão cordial (2012). A obra de Brecht, não só a erguemos em improvisações dispensando as leituras antecipadas do texto (análise ativa), como dissolvemos as disparidades entre a compreensão intelectual e a fluência emotiva. Sobretudo, no elenco, foi preciso coligir a rejeição e a atração da criada Grusha pela criança abandonada, assim como a subornabilidade e a probidade de Azdak enquanto Juiz, citando apenas dois personagens da peça. E Ópera dos vivos guardava a dialética em sua arquitetura. As vozes contrárias à emancipação tinham tanto ou mais força que as progressistas e nem sempre a nossa opção por um dos lados em disputa era de simples resolução. Como se identificar com uma personagem como Dora Helena que, enquanto desmascarava a entropia do modo de produção televisivo, bebia e ingeria medicamentos psiquiátricos nos estúdios? Por sua vez, O patrão cordial carregava no título a contradição com esse proprietário favorável às causas de seus próprios trabalhadores quando alcoolizado e, se sóbrio, reagindo irascivelmente regressivo.

A noção das ações físicas, que vinha ganhando cada vez mais espaço dentro do grupo, firmou-se mais nitidamente entre nós também em $O$ patrão cordial. Adiconamos às nossas 
pesquisas a inquietação de cometer atos corporais em cada cena da obra priorizando os gestus dos papéis ${ }^{127}$.

Nesses útlimos trabalhos, creio termos alcançado um maior entendimento sobre o modo dialético de atuar. Havia, desde os ensaios, iniciativas em direção às contradições entre os aspectos internos e externos dos personagens em desenvolvimento. Entretanto, as fronteiras de quando uma postura intepretativa contrastante se fez mais ou menos presente não são tão claras e o que fiz nesta pesquisa foi menos determinar cronologicamente do que organizar em fases os nossos vinte anos de teatro ligados a questões sociais.

Contudo, depois de treze espetáculos e onze experimentos cênicos campeando evitar a representação dramatizada sem antíteses, ainda é frequente resvalarmos em modos não dialéticos de interpretar, principalmente quando improvisamos nos ensaios. É preciso que algum colega acerte a mão, programadamente ou não, em uma feliz jogada teatral contraditória, para que os demais se sintam instigados a também fazê-lo, pois não é sempre que de saída nos articulemos dialeticamente. Muitas vezes a direção propõe a inversão dos termos em nossos esboços teatrais, redimensionando o que é engendrado pelo elenco no sentido de implantar polarizações e então, a partir do que assinalamos, crescem as chances de mostrarmos frações teatrais com traços antinômicos.

No correr dos nossos encontros, nenhum de nós é obsessivo pelas colisões ideológicas ou polarizações econômicas, todavia sente-se a falta de que os conflitos se ampliem em direção à compreensão dos problemas entre os homens. E isso não afeta apenas o público, mas identicamente os próprios atores. Tal indústria não é apenas intelectual, ainda que a razão seja um atributo para o nosso coletivo. Resumidamente, o preparo para contraditar conceitos e juízos acidentalmente em nossos treinos geralmente começa com um trabalho musical e jogos que apontem para o universo da pesquisa em curso. O preparo físico se soma a esse momento inicial, embora cada atriz ou ator também o faça individualmente fora do espaço comum. $\mathrm{Na}$ sequência, passamos por um módulo que internamente chamamos de "exercícios imaginários", os quais, simultaneamente, desenvolvem a criatividade enquanto articulam sugestões utilizáveis ou não pela direção em determinados processos. Depois costumamos entrar nas cenas a serem experimentadas, partindo do tema geral ou de partes, personagens, paralelismos sobre os assuntos em escolhas etc. Tendo como norte os paradoxos, usualmente

\footnotetext{
${ }^{127}$ Não sem razão, em $O$ pão e a pedra (2016), a principal requisição aos atores por parte da direção foi justamente a de realizarmos atitudes cênicas gestuais.
} 
nos é concedido tempo para combinar e ensaiar com os colegas para, em seguida, apresentarmos o que preparamos. A partir do que delineamos na sala, a coordenação normalmente interfere em uma ou outra elaboração do elenco, transformando o caráter dos intentos, inserindo narrativas ou canções e, nessas permutas, vão surgindo as possibilidades para a peça.

Vale lembrar que a nossa dramaturgia sempre produz autonomamente suas concepções e roteiros e expressa situações e personagens que, em certa medida, irão se cruzar com a produção dos atores. É desse campo, incluindo naturalmente outros procedimentos, recursos e condutas, que nascem as condições para que os elencos operem dialeticamente. No transcorrer das temporadas, aprimoramentos são realizado em ensaios prévios às sessões, para que aquilo que não teve suficiente preparo antes das apresentações públicas venha a ganhar dimensão contraditória, se preciso for.

Arrematando, o ator dialético na Companhia do Latão é também um pouco dramaturgo e encenador, vivencia as ações e é narrador, transita entre o épico, o dramático e o lírico. Distancia-se dos papéis de distintos modos. Por vezes interpreta de forma indicada (sem se envolver tanto com os personagens), noutras a eles se entrega, ainda que intermitentemente, em encenações ensaísticas, fragmentadas ou inacabadas. Paramenta-se diante do público (quase não usa os bastidores) e faz com pequenos adereços as caracterizações para os seus papéis. Atua em coros, canta, compõe e, se necessário, toca algum instrumento. Pratica exercícios para fortalcecer a imaginação e tem uma atitude realista. Utiliza-se do princípio nodal da contradição, age pelas ações psicofísicas, improvisa muito nos ensaios e tem gosto pelos estudos, pelo aprendizado sobre as matérias a serem teatralizadas. Investiga os deslocamentos das posições sociais, sondando o desenraizamento dos indivíduos no mundo financeirizado. É politizado e cultiva valores anticapitalistas, solidários e gregários. Tem prazer de trabalhar em grupo, porém sua sobrevivência material também depende de atividades paralelas à companhia. Não são poucos os problemas, contudo as afinidades compensam as diferenças ao improvisarmos preparando um espetáculo ou, em apresentações, quando entramos em contato com públicos diversos, que vão dos frequentadores de teatro aos movimentos sociais, mobilizando-nos mutuamente em torno de uma nossa peça, debate ou oficina.

A sala de ensaio se transformou num lugar onde a obra foi sendo construída de maneira coletiva, em que foi fundamental a contribuição de cada um que esteve envolvido, seja da técnica ou da direção. Toda ideia foi ouvida e discutida de forma que as dúvidas de uma época passada e as agonias dos tempos atuais pudessem servir de potência ao que vinha à 
cena. Os postos perderam sua fixidez: a assistente de direção subiu ao palco, uma participante da equipe de pesquisa tomava seu lugar enquanto uma atriz entregava uma letra para o músico compor uma canção. A dramaturgia foi sendo escrita seguindo as propostas dos atores, retrabalhadas por um diretor que sem cessar subia em cena para atuar. Ninguém parou quieto. E talvez esse jeito de produzir é que seja a mais viva homenagem que podíamos prestar àqueles peões que, para fazer o tempo da máquina parar, tiveram que suspender o que eram e imaginar a possibilidade de ser outro, olhando e construindo a existência para além do tempo administrado (CARVALHO, 2016, p. 2). ${ }^{128}$

A conversão do convívio grupal em constituição artística, como descrito acima, é para nós modelar e resume o exercício inventivo dos projetos da Companhia. Sendo que o motivo primordial das nossas opções, "não é porque somos marxistas, dialéticos, mas porque é mais vivo, mais humano" (informação pessoal) ${ }^{129}$.

Foram vinte anos atuando para eu escrever este livro, e não tenho dúvidas de que colocar no papel os estudos sobre como atuar segundo o princípio da contradição, tornou-me ainda mais dialético no teatro e na vida: negativa ou positivamente.

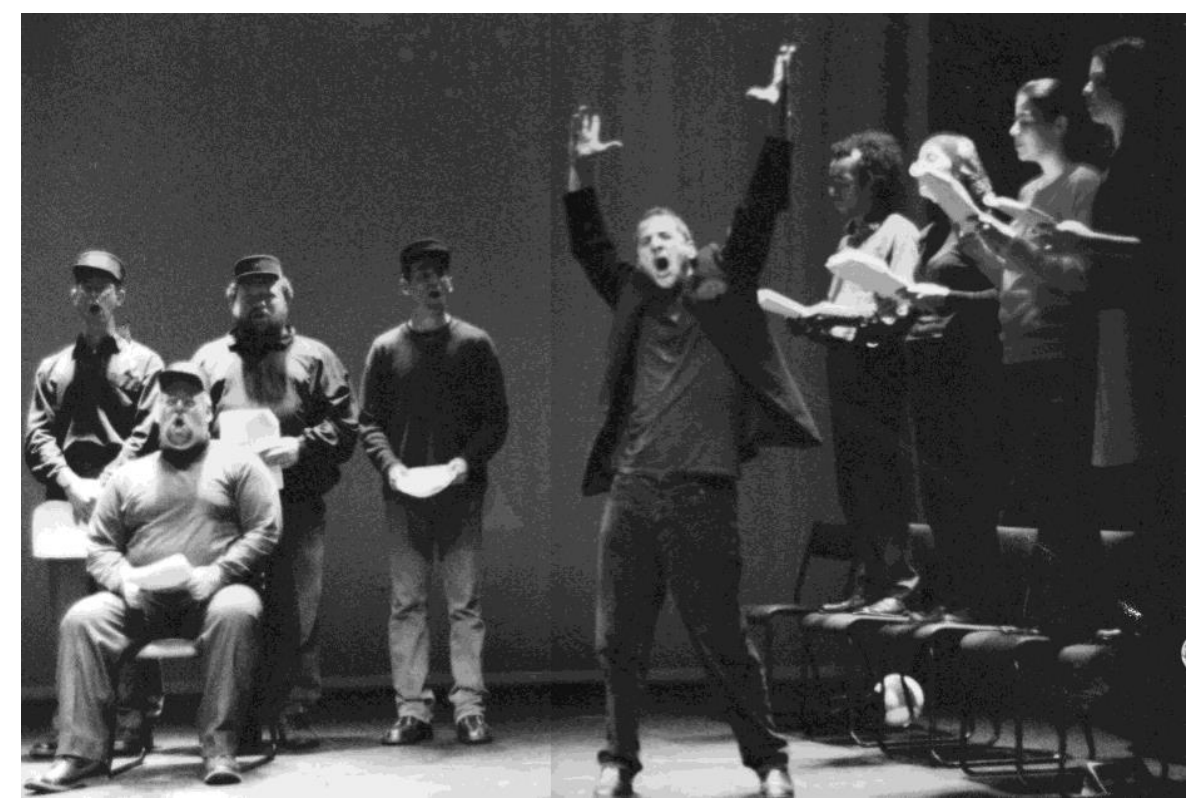

Beto Matos, Heitor Goldflus, Marcelo Preto, Emerson Rossini, Ney Piacentini, Ney Mesquita, Helena Albergaria, Alesssandra Fernandez, Renata Deuse. Valor de troca (experimento cênico, 2002). Foto: Sérgio de Carvalho.

\footnotetext{
128 Trecho do texto do programa da peça $O$ pão e a pedra, escrito por Sérgio de Carvalho, em maio de 2016.

${ }^{129}$ Helena Albergaria, em depoimento a Ney Piacentini, em 13 jun. 2016.
} 


\section{REFERÊNCIAS BIBLIOGRÁFICAS}

Livros:

ANCHIETA, José de. Cartas jesuíticas 3: fragmentos históricos e sermões. São Paulo: Edusp, 1988.

AUTANT-MATHIEU, Marie-Christine. La ligne des actions physiques. Paris: L'Entretemps étidions, 2007.

BADER, Wolfgang. Brecht no Brasil. Experiências e influências. Rio de Janeiro: Paz e Terra, 1987.

BARBA, Eugênio. Queimar a casa. São Paulo: Perspectiva, 2010.

Bíblia. São Paulo: Paulus, 1990, p. 1493.

BOAL, Augusto. 200 exercícios e jogos para o ator e não-ator com vontade de dizer algo através do teatro. Rio de Janeiro: Civilização Brasileira, 1982.

. Hamlet e o filho do padeiro. São Paulo: Cosac Naify, 2014.

BRECHT, Bertolt. A compra do latão. Lisboa: Vega, 1999.

. A mãe. Bertolt Brecht Teatro Completo 4. Rio de Janeiro: Paz e Terra, 1990.

. A Santa Joana dos Matadouros. São Paulo: Paz e Terra, 1997.

. Escritos sobre teatro, vol. 1. Buenos Aires: Nueva Visión, 1970.

. Escritos sobre teatro, vol. 2. Buenos Aires: Nueva Visión, 1970.

. Histórias do Senhor Keuner. São Paulo: Brasiliense, 1979.

. O círculo de giz caucasiano. São Paulo: Cosac Naify, 2002.

. O senhor Puntila e seu criado Matti. São Paulo: Civilização Brasileira, 1966. 
. Pequeno Organon para o teatro. In: Estudos sobre teatro. Rio de Janeiro: Nova Fronteira, 1978. . Poemas 1913-1956. São Paulo: Editora 34, 1990.

BROOK, Peter. Não há segredos. São Paulo: Via Lettera, 2016. . O teatro e seu espaço. Rio de Janeiro: Vozes, 1970.

CARVALHO, Sérgio; MARCIANO, Marcio. Companhia do Latão: 7 peças. São Paulo: Cosac Naify, 2008.

CARVALHO, Sérgio (org.). Introdução ao teatro dialético: experimentos da Companhia do Latão. São Paulo: Expressão Popular, 2009. Atuação crítica: entrevistas da Vintém e outras conversas. São Paulo: Expressão Popular, 2009.

Ópera dos vivos: um estudo teatral em quatro atos. São Paulo: Outras Expressões, 2014.

CHACRA, Sandra. Natureza e sentido da improvisação teatral. São Paulo: Perspectiva, 1983.

COLETIVO NACIONAL DE CULTURA - BRIGADA NACIONAL PATATIVA DO ASSARÉ (org.). Teatro e transformação social - Vol. 2 - Teatro Épico. São Paulo: Centro de Formação e Pesquisa Contestado, 2006.

FLASZEN, Ludwik; POLLASTRELLI, Carla. O teatro laboratório de Jerzy Grotowisky. São Paulo: Perspectiva, 2010.

FO, Dario. Manual mínimo do ator. São Paulo: Editora Senac, 2004.

FRANCO, Maria Sylvia de Carvalho. Homens livres na ordem escravocrata. São Paulo: Edusp, 1969.

FREDERICO, Celso. A vanguarda operária. São Paulo: Símbolo, 1979. . Consciência operária no Brasil. São Paulo: Ática, 1979. 
FREYRE, Gilberto. Açúcar. São Paulo: Companhia das Letras, 1997. . Assombrações do Recife Velho. São Paulo: José Olympio, 1974. . Casa Grande e Senzala. Rio de Janeiro: Record, 1996. Guia Prático, Histórico e Sentimental da Cidade do Recife. São Paulo: José Olympio, 1961. . Sobrados e Mucambos. São Paulo: José Olympio, 1961.

GOETHE, Johann Wolfgang von. Fausto. São Paulo: Agir, 1968.

GORCHAKOV, Nicolai. Las lecciones de "régisseur" de Stanislavski. Montevidéo: Ediciones Pueblos Unidos, 1956.

GORDON, Mel. The Stanislavsky Technique. New York: Applause Theatre Book Publishers. 1994.

GROTOWSKI, Jerzy. Em busca de um teatro pobre. Rio de Janeiro: Civilização Brasileira, 1987.

GUARNIERI, Gianfrancesco. A semente. Rio de Janeiro: Civilização Brasileira. 1978.

HEGEL, Georg Wilhelm Friedrich. O movimento do pensamento. Textos editados e traduzidos (do espanhol e do inglês) por Iná Camargo Costa, ainda sem publicação. São Paulo, 2017.

HOLANDA, Sérgio Buarque de. Raízes do Brasil. São Paulo: Companhia das Letras, 1995.

HOUAISS, Antônio. Dicionário Houaiss da Língua Portuguesa. Rio de Janeiro: Objetiva, 2009.

JAMESON, Fredric. O método Brecht. Petrópolis: Vozes, 1999.

JIMENEZ, Sergio (org.). El evangelio de Stanislavski según sus apóstoles: los apócrifos, la reforma, los falsos profetas y Judas Iscariote. Ciudad de México: Grupo Editorial Gazeta, 1990. 
KNEBEL, Maria. El Último Stanislavsky. Madrid: Editorial Fundamentos. 1999. . Poetica de la pedagogia teatral. Ciudad de México: Siglo Veintiuno Editores. 1991.

KONDER, Leandro. O que é dialética. São Paulo: Brasiliense, 2012.

KUSNET, Eugênio. Ator e Método. Rio de Janeiro: Funarte, 1997. . Depoimento ao Serviço Nacional de Teatro realizado no Teatro Anchieta em São Paulo, em oito de janeiro de 1975. (Cópia de apostila datilografada.)

LESSA, Sérgio; TONET, Ivo. Introdução à filosofia de Marx. São Paulo: Expressão Popular, 2008 .

LINHART, Robert. Greve na fábrica. Rio de Janeiro: Paz e Terra, 1970.

MARCOS, Plínio. Quando as máquinas param. São Paulo: Obelisco, 1971.

MARLOWE, Christopher. História trágica do doutor Fausto. São Paulo: Hedra, 2011.

MARX, Karl. O capital. Livro 1: o processo de produção do capital, volumes 1 e 2 . Rio de Janeiro: Civilização Brasileira, 1980.

MASI, Domenico de. O ócio criativo. Rio de Janeiro: Sextante, 1997.

MEICHES, Mauro; FERNANDES, Sílvia. Sobre o trabalho do ator. São Paulo: Perspectiva, 1988.

MILARÉ, Sebastião. Hierofania: o teatro segundo Antunes Filho. São Paulo: Editora Senac, 2010.

OIDA, Yoshi. Um ator errante. São Paulo: Beca Produções Culturais, 1999. . O ator invisível. São Paulo: Via Lettera, 1997.

PAVIS, Patrice. Dicionário de Teatro. São Paulo: Perspectiva, 1999.

PIACENTINI, Ney. Eugênio Kusnet: do ator ao professor. São Paulo: Hucitec, 2014. 
PIACENTINI, Ney; FÁVARI, Paulo (orgs.). Stanislavski revivido. São Paulo: Giostri Editora, 2014.

POLITZER, Georges. Princípios elementares de filosofia. Rio de Janeiro: Prelo, 1979.

RICHARD, Thomas. Trabalhar com Grotowski sobre as ações físicas. São Paulo: Perspectiva, 2012.

ROJAS, Mario A. El “Auto dos Bons Tratos" de La Companhia do Latão y la desritualización de la historia. In: PELLETTIERE, Osvaldo. Escena y realidad. Buenos Aires: Galerna/Universidad de Buenos Aires, 2003, p. 75-82.

ROSENFELD, Anatol. O teatro épico. São Paulo: Perspectiva, 2006.

ROUBINE, Jean-Jacques. A linguagem da encenação teatral. Rio de Janeiro: Jorge Zahar Editor, 1998.

SARTRE, Jean-Paul. A imaginação. São Paulo: L\&PM Editores, 2008.

SCHWARZ, Roberto. 03 ESTUDO, SJM Bertolt Brecht teatro Completo 4. Rio de Janeiro: Paz e Terra, 1990.

SERRANO, Raúl. Nuevas Tesis sobre Stanislavsky. Buenos Aires: Atuel, 2004.

SPOLIN, Viola. O fichário de Viola Spolin. São Paulo: Perspectiva, 2012. . Improvisação para o teatro. São Paulo: Perspectiva, 2012.

STANISLAVSKI, Constantin. A criação de um papel. Rio de Janeiro: Civilização Brasileira. 1972. El trabajo del actor sobre sí mismo en el proceso criador de la vivencia. Barcelona: Alba Editorial, 2003. . El trabajo del actor sobre sí mismo en el proceso criador de la encarnación. Barcelona: Alba Editorial, 2003. . El arte escénico. Ciudad de México: Siglo Veintiuno Editores, 1968. 
Ética y disciplina (Método de acciones físicas). Ciudad de México: Grupo Editorial Gaceta, 1994.

. Entretiens au Studio du Bolchoi \& L'Éthique. Strasburg: Circe, 2012.

. Notes artistiques (ponser le théâtre). Strasburg: Circe, 1997.

. Trabajos Teatrales: correspondência. Buenos Aires: Quetzal, 1986.

TOPORKOV, Vasily Osipovich. Stanislavsky in Rehearsal. New York: Routlledege, 1998.

URBINATTI, Tim. Peões em cena. São Paulo: Hucitec, 2011.

Revistas:

BORNHEIN, Gerd. Brecht e a cultura da separação. Revista Vintém, São Paulo, n. 0, p. 4, 1997. Entrevista.

BUCCI, Eugênio. O capitalismo da produção da imagem. Revista Vintém, São Paulo, n. 5, p. 22, 2004. Transcrição de palestra.

LEHMANN, Hans Thies. Dossiê Heiner Müller. Revista Vintém, São Paulo, n. 5, p. 45, 2004. Transcrição de oficina.

MARCIANO, Márcio. Primeiros movimentos. Revista Vintém, São Paulo, n. 0, p. 38-39, jul.ago. 1977.

. Visões Siamesas: uma dramaturgia do limite. Revista Vintém, São Paulo, n. 6, p. 44, 2007. Artigo.

MÜLLER, Heiner. Dossiê Heiner Müller. Revista Vintém, São Paulo, n. 5, p. 26, 2004. Entrevista.

. Dossiê Heiner Müller. Revista Vintém, São Paulo, n. 5. p. 37, 2004. Entrevista.

PALITZSCH, Peter. O trabalho de Peter Palitzsch com a Companhia do Latão. Revista Vintém, São Paulo, n. 3. p. 40, 41, 2006. Transcrição de oficina.

SCHWARZ, Roberto. A atualidade de Brecht. Revista Vintém, São Paulo, n. 1, fev.-mar.-abr. 1977 , p. 29. 
STILLMARK, Alexander. Oficinas dos diretores alemães Peter Palitzsch e Alexander Stillmark. Revista Vintém, São Paulo, n. 3. p. 43, 1999. Transcrição de oficina.

Jornais:

CARVALHO, Sérgio de. A consistência do Latão. Jornal do Brasil, Rio de Janeiro, 28 set. 1999. Caderno B, p. 01. Entrevista a Eduardo Graça.

Cia do Latão. Jornal Agacen, Porto Alegre, nov.-dez. 1998, p. 5. Depoimento a Marcio Silveira.

. Entrevista. Correio Brasiliense, Brasília, 19 mar. 1998, Caderno Pensar, p. 3.

Entrevista a Fernando Marques.

. O coletivo teatral acima de tudo. Jornal Inverta, Rio de Janeiro, 21 a 27 jul.

1999, p. 4-B. Entrevista a Charles Aleixo.

. "O nome do sujeito" rastreia o comércio de almas no Recife. Folha de S.Paulo,

São Paulo, 09 out. 1998. Caderno Ilustrada, p. 5-13. Entrevista a Bruno Garcez.

COELHO, Sérgio Salvia. Cia do Latão atinge a lucidez pela emoção. Folha de S.Paulo, São Paulo, 04 dez. 2004, Caderno Ilustrada, 5-2, p. 12. Crítica.

CONTI, Mário Sergio. Pai, pedra e pão. Folha de S.Paulo, São Paulo, 31 maio 2016. Primeiro Caderno, p. A7. Crítica.

FONSECA, João. O mercado do gozo. O Sarrafo, São Paulo, ago. 2003, p. 11. Crítica.

GUZIK, Alberto. Política mostra a cara no Festival de Curitiba. O Estado de S. Paulo, São Paulo, 30 mar. 2002, Caderno 2, p. D5. Crítica.

HELIODORA, Bárbara. Inesperada ressureição dos anos 60. O Globo, Rio de Janeiro, 30 jul. 1999. Segundo Caderno, p. 3. Crítica.

LIMA, Fátima; PIACENTINI, Ney. Tentativa de unidade. Diário Catarinense, Florianópolis, 30 ago. 2014, Caderno Cultura, p. 01. Artigo.

LIMA, Mariângela Alves de. Cia do Latão ganha ao unir Machado e Brecht. O Estado de S. Paulo, São Paulo, 26 nov. 2004, p. D9. Crítica.

. Espetáculo questiona função da arte. O Estado de S. Paulo, São Paulo, 19 set. 1999, Caderno 2, p. D30. 
. Latão cria inquietante jogo de ilusão. O Estado de S. Paulo, São Paulo, 19 set. 2003, Caderno 2, p. D5. Crítica.

SÁ, Nelson de. "Santa Joana 5" ganha em clareza e perde em humor. Folha de S.Paulo, 19 jun. 1988, p. 5-6. Caderno Ilustrada. Crítica.

Sítios na internet:

ANDRADE, Welington. Distanciar é ver em termos históricos. Revista Cult, São Paulo, em 25 nov. 2013. Disponível em: <http://revistacult.uol.com.br/home/distanciar-e-ver-em-termos históricos/>. Acesso em: 09 jan. 2018.

COMPANHIA DO LATÃO. Disponível em: 〈http://www.companhiadolatao.com.br〉.

SANTOS, Joana da Costa. Ópera dos vivos. Crítica Hoje, Coimbra - Universidade de Coimbra, em 26 jun. 2014.2 Disponível em: <http://criticahoje.wordpress.com/2014/06/26/309/>.

Filmografia:

1900. Direção: Bernardo Bertolucci, 1976, 35mm.

ABC da greve. Direção: Leon Hirszman. 1979/80. 16mm.

Linha de montagem. Direção: Renato Tapajós, 1981, 35mm.

Peões. Direção: Eduardo Coutinho, 2004, 35mm.

Terra em transe. Direção: Glauber Rocha, 1967, 35mm.

Eles não usam black-tie: Direção: Leon Hirszman, 1981, 35mm.

Peões. Direção: Eduardo Coutinho, 2004, 35mm.

Outros: 
MESQUITA, Lauro; CARVALHO, Sérgio de; MARCIANO, Márcio (eds.). Caderno de Apontamentos - A comédia do trabalho. São Paulo: Edições do Latão, 2000. 